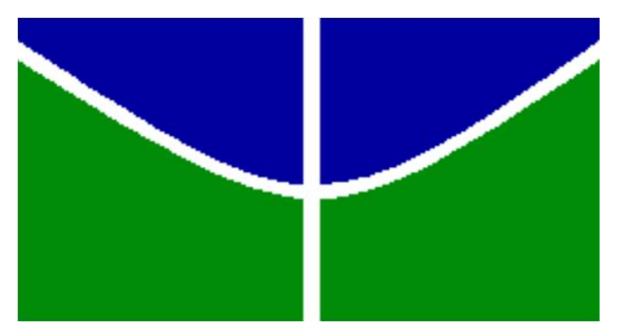

UNIVERSIDADE DE BRASÍLIA

FACULDADE DE EDUCAÇÃO

PROGRAMA DE PÓS-GRADUAÇÃO EM EDUCAÇÃO

MODALIDADE PROFISSIONAL

CLAUDIO ALEXANDRE GUSMÃO

EDUCAÇÃO PROFISSIONAL TÉCNICA DE NÍVEL MÉDIO INTEGRADA AO ENSINO MÉDIO: A Perda do Caráter Profissionalizante?

BRASÍLIA - DF

FEVEREIRO DE 2016 


\section{EDUCAÇÃO PROFISSIONAL TÉCNICA DE NÍVEL MÉDIO INTEGRADA AO ENSINO MÉDIO: A Perda do Caráter Profissionalizante?}

Dissertação apresentada ao Programa de Pós-Graduação em Educação-Modalidade Profissional, da Faculdade de Educação da Universidade de Brasília - UnB, como requisito para a obtenção do título de Mestre em Educação na área de Políticas Públicas e Gestão da Educação Profissional e Tecnológica, sob a orientação da Prof. ${ }^{a}$ Dra $^{a}$. Olgamir Francisco de Carvalho.

BRASÍLIA - DF

FEVEREIRO DE 2016 
Gusmão, Claudio Alexandre

GG982e Educação profissional técnica de nível médio integrada ao ensino médio: a perda do caráter profissionalizante? / Claudio Alexandre Gusmão; orientador Olgamir Francisco de Carvalho. -Brasília, 2016. $181 \mathrm{p}$.

Dissertação (Mestrado - Mestrado Profissional em Educação) -- Universidade de Brasília, 2016.

1. Ensino Integrado. 2. Motivação Discente. 3. Perda do Caráter Profissionalizante. 4. Mercado de Trabalho. 5. Ensino Superior. I. Carvalho, Olgamir Francisco de, orient. II. Título. 


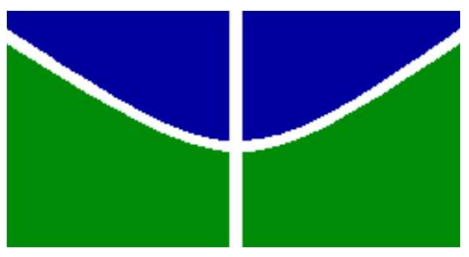

\section{UNIVERSIDADE DE BRASÍLIA \\ FACULDADE DE EDUCAÇÃO \\ PROGRAMA DE PÓS-GRADUAÇÃO EM EDUCAÇÃO \\ MESTRADO PROFISSIONAL}

Dissertação intitulada "EDUCAÇÃO PROFISSIONAL TÉCNICA DE NÍVEL MÉDIO INTEGRADA AO ENSINO MÉDIO: A Perda do Caráter Profissionalizante? " de autoria de Claudio Alexandre Gusmão, aprovada pela banca examinadora constituída pelos seguintes professores:

\section{Prof. ${ }^{a}$. Dr ${ }^{\mathrm{a}}$. Olgamir Francisco de Carvalho - Orientadora}

Faculdade de Educação - UnB

Prof. Dr. Remi Castioni - Membro Interno

Faculdade de Educação - Unb

Prof. Dr. Giuliano Viana de Alkmim - Membro Externo

IFNMG-Januária

Prof. Dr. Bernardo Kipnis - Suplente

Faculdade de Educação - Unb

Data de aprovação: Brasília, 23 de Fevereiro de 2016

Campus Universitário Darcy Ribeiro - Faculdade de Educação - Asa Norte Brasília -

$$
\text { DF - Cep: 70.910-900 }
$$

Telefones: +55 0xx61 3307-2130 FAX: +55 0xx61 3307-3826

fed@unb.br 
${ }^{\mathbf{6 6}}$ Toda decisão que você toma - toda decisão - não é uma decisão sobre o que você faz. É uma decisão sobre Quem Você É. Quando você vê isso, quando você entende isso, tudo muda. Você começa a ver a vida de um modo novo. Todos eventos, ocorrências, e situações se transformam em oportunidades para fazer o que você veio fazer aqui. " - Neale Donald Walsch 


\section{AGRADECIMENTOS}

Agradeço a todos que estiveram diretamente e indiretamente me auxiliando durante a jornada de estudos do mestrado, tanto no plano material quanto no plano espiritual.

Agradeço a todos pela experiência vivida, sinceramente o meu Muito Obrigado! Ao agradecer a todos vocês também estou agradecendo a DEUS, pois somos um com ELE. 
Só existe um de nós.

Neale Donald Walsch 
Esta dissertação pesquisou o fenômeno da Perda do Caráter Profissionalizante da Modalidade Ensino Técnico Integrado ao Ensino Médio nas Instituições Federais Profissionalizantes presente nas experiências de integração com a Lei 5.692/71 e o Decreto 5.154/04. O estudo evidenciou em sua análise a forte característica propedêutica da modalidade integrada, o desinteresse da clientela pela habilitação profissional e também o descuido com o estágio supervisionado, evidenciando a perda do caráter profissionalizante da política pública do ensino integrado. Além da análise de caráter mais geral feita a partir dos resultados de pesquisas desenvolvidas sobre essa modalidade, foi realizada também, uma pesquisa de campo no IFNMG-Januária, com a hipótese de que o fenômeno também ocorria na Instituição. A referida pesquisa, de abordagem mista explanatória sequencial, constatou a perda do caráter profissionalizante no ensino integrado da Instituição, ainda mais acentuadamente, no curso integrado de estágio supervisionado não obrigatório (opcional). Por fim, diante da constatação da importância do estágio supervisionado percebida na pesquisa de campo para o resgate do caráter profissionalizante da política pública e, para assegurar o caráter profissional da dissertação, foi elaborado um Produto Técnico contendo Orientações para Implantação e Execução do Estágio Supervisionado em cursos técnicos integrados do IFNMG para auxiliar no debate e aprimoramento da política de estágio praticada nas Instituições que ofertam o ensino integrado. Tal proposta objetiva valorizar esse importante componente curricular integrador, consolidando o caráter profissionalizante da política pública assim como está consolidado o caráter propedêutico, em uma perspectiva onde a formação para a cidadania se integra, organicamente, à formação para o trabalho.

Palavras-chave: Ensino Integrado; Estágio Supervisionado; Identidade; Profissionalizante; Propedêutico. 


\begin{abstract}
This dissertation researched the phenomenon of loss of professionalizing character of Technical Education modality integrated to High School at Professionalizing Federal Institutions, present in the integration experiences with the Law 5.692/71 and Decree $5.154 / 04$. The study showed in its analysis a strong propaedeutic feature of integrated modality, the lack of interest of students by professional qualification and also the carelessness with the supervised training, evidencing the loss of professionalizing character of Public Policy of Integrated Education. Beyond the general analysis made from developed research results on this modality, it was also carried out a field research at IFNMG-Januária, with the hypothesis that the phenomenon also occurred in the institution. Such research, of mixed sequential explanatory approach, found the loss of professionalizing character in integrated Education of Institution, even more sharply in integrated course of supervised training not required (optional). Finally, front of awareness of supervised training importance perceived in field research to the rescue of the professionalizing character of public policy and to ensure the professional character of the dissertation, it was designed a Technical Product containing Guidelines for the Implementation and Execution of Supervised Training in integrated technical courses from IFNMG to assist in the discussion and improvement of supervised training policy practiced in the institutions that offer the integrated teaching. Such proposal aims to value this important integrator curricular component, consolidating the professionalizing character of public policy as it is consolidated the propaedeutic character, in a perspective where training for citizenship integrates organically, training for the job.
\end{abstract}

Keywords: Integrated Education; Supervised Training; Identity; Professionalizing; Propaedeutic. 


\section{LISTA DE ILUSTRAÇÕES}

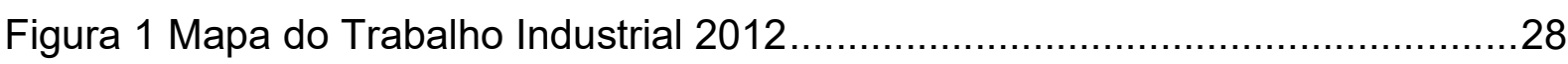

Figura 2 Grupo de Estudantes dos Institutos Federais no Facebook .......................43

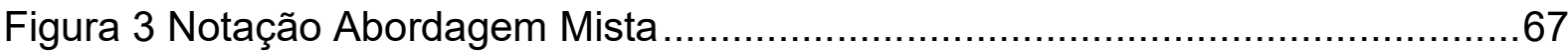

Figura 4 Nuvem de Palavras Atratividade do Ensino Integrado ............................107

Figura 5 Importância do Estágio Supervisionado ..............................................114

Figura 6 Percepção de Aumento da Duração do Curso Integrado...........................124

Tabela 1 Médias do ENEM 2014 por Dependência Administrativa ..........................44

Tabela 2 Quantitativo de Questionários Aplicados ...............................................77

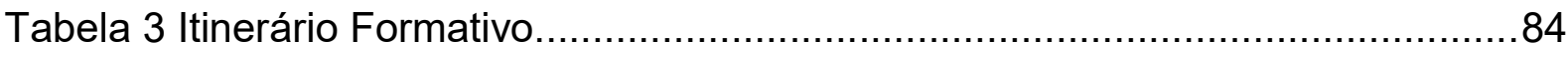

Tabela 4 Conhecimento Sobre Estágio Supervisionado ......................................8

Tabela 5 Quantidade de alunos de Agropecuária que sabem o que é Estágio

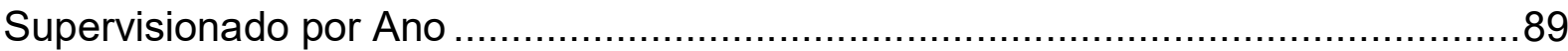

Tabela 6 Opinião dos Discentes que não conhecem o termo estágio supervisionado

Tabela 7 Divulgação do Estágio Supervisionado .90

Tabela 8 Desejo de Trabalhar na Área Técnica Quando Ingressou por Ano -

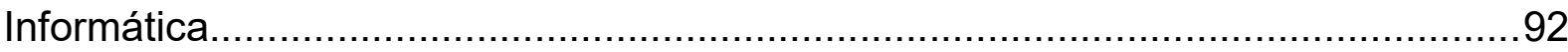

Tabela 9 Desejo Atual de Trabalhar na Área Técnica por Ano - Informática............92 Tabela 10 Desejo de Trabalhar na Área Técnica Quando Ingressou - Agropecuária

Tabela 11 Desejo de Trabalhar na Área Técnica Atualmente - Agropecuária ..........93

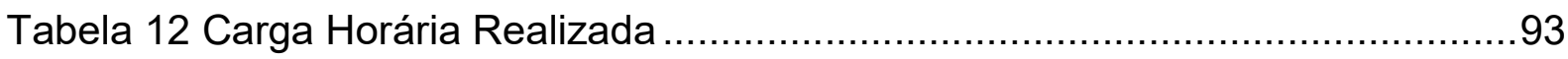

Tabela 13 Necessidade de Aprendizado de Outros Conhecimentos ......................101 


\section{LISTA DE GRÁFICOS}

Gráfico 1 Desempenho comparado no Enem de alunos de escolas técnicas de diferentes redes de educação profissional, por área de conhecimento, em $2010 \ldots . .45$ Gráfico 2 Distribuição dos Discentes por ano em curso ..................................78 Gráfico 3 Motivação/Interesse em Prosseguimento nos Estudos ...........................79 Gráfico 4 Motivação/Interesse no Mercado de Trabalho ....................................79

Gráfico 5 Interesse em Cursar Somente o Médio ou Técnico ..............................81

Gráfico 6 Orientação dos Pais Vestibular x Trabalho ......................................... 81

Gráfico 7 Formação dada Pela Instituição x Desejo de Formação do Aluno ............82

Gráfico 8 Maior objetivo dos alunos após a conclusão do curso...........................83 Gráfico 9 Maior objetivo dos alunos do $3^{\circ}$ Ano Informática após a conlusão do curso

Gráfico 10 Maior objetivo dos alunos do $3^{\circ}$ Ano Agropecuária após a conclusão do curso .84

Gráfico 11 Desejo de Fazer Curso Superior na Área de Formação - $3^{\circ}$ anos .85

Gráfico 12 Egressos Itinerário Formativo .87

Gráfico 13 Acompanhamento do IFNMG x Acompanhamento da Concedente . .94

Gráfico 14 Acompanhamento pelo Professor Orientador .95

Gráfico 15 Interesse em Cursar o Integrado com Mais de 3 Anos 100

Gráfico 16 Importância do Estágio para o Discente 102

Gráfico 17 Percepção de Preparo Profissional. 103 


\section{SUMÁRIO}

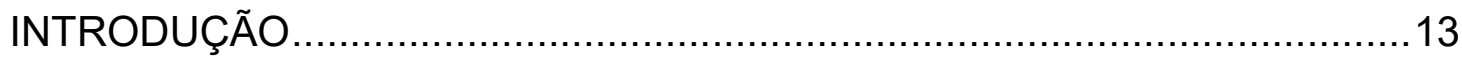

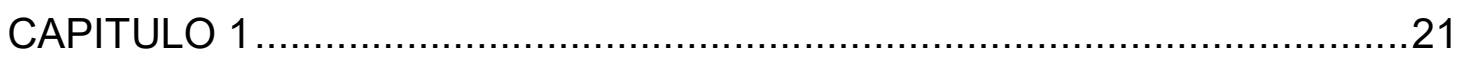

O ENSINO INTEGRADO NAS INSTITUIÇÕES FEDERAIS

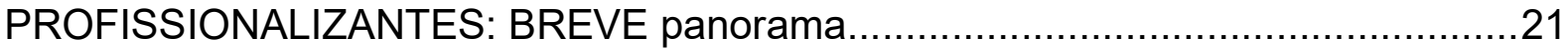

1.1 O Ensino Integrado nas Décadas de 80 e $90 \ldots \ldots \ldots \ldots \ldots \ldots \ldots \ldots \ldots \ldots \ldots \ldots . . .21$

1.2 O Ensino Integrado na Vigência do Decreto $n^{0} 5.154 / 04 \ldots \ldots \ldots \ldots \ldots \ldots \ldots . . .24$

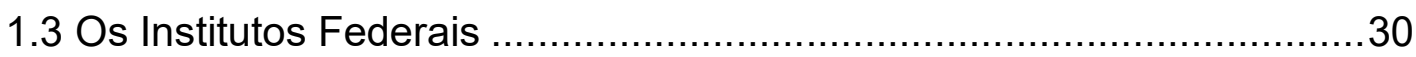

1.4 Relatos da Modalidade Integrada nos Institutos Federais......................35

1.5 Destacando a Importância do Estágio Supervisionado no Ensino Integrado.

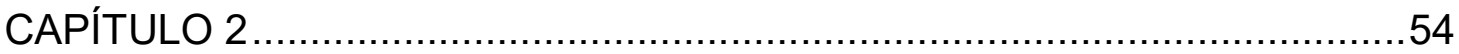

O CARÁTER PROFISSIONALIZANTE NOS CURSOS TÉCNICOS

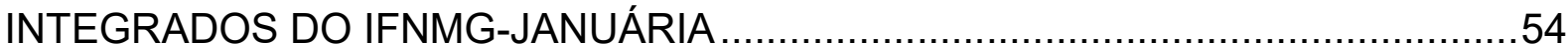

2.1 Lócus da pesquisa: IFNMG - Campus Januária …………………......54

2.1.1 Contextualização do Estágio Supervisionado no IFNMG ............58

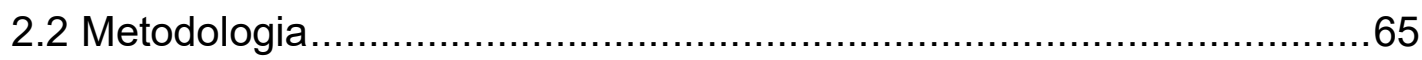

2.2.1 População, Coleta e Análise de Dados .....................................68

2.2.2 Interpretação de Toda Análise: Quantitativa + Qualitativa ...........75

2.3 Resultados da Pesquisa de Campo .................................................

2.3.1 A aplicação dos questionários na pesquisa piloto ........................76

2.3.2 Análise da Fase Quantitativa.................................................77

2.3.3 Análise da Fase Qualitativa...................................................104

2.4 Interpretação de Toda Análise: Ensino Integrado de Três Anos é Interessante aos já Incluídos .................................................................128

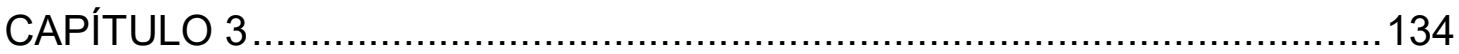

Orientações para a Realização do Estágio Supervisionado noS CURSOS INTEGRADOS DO INSTITUTO FEDERAL DO NORTE DE MINAS GERAIS ........134

3.1 O Estágio Supervisionado: Breve Introdução....................................136

3.1.1 A Questão da Obrigatoriedade ..............................................136

3.1.2 A Questão da Duração e Carga Horária ...................................144

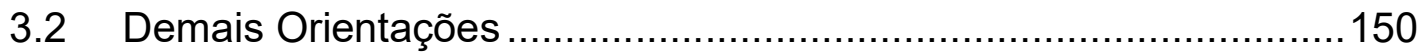


3.2.1 Esclarecimento da Importância do Estágio Supervisionado ao Estudante e Acesso a Documentação Regulatória 151

3.2.2 Período de realização do estágio 151

3.2.3 Acompanhamento do estagiário pelo professor orientador 151

3.2.4 Momento de Compartilhamento de Saberes dos Estagiários ...152

3.2.5 Desenvolvimento do Estágio em Ambiente Laboral Real. 153

3.2.6 Inclusão do Estágio Não Obrigatório Como Componente Curricular 153

CONSIDERAÇÕES FINAIS 154

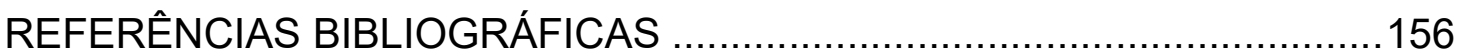

Apêndices 162

Apêndice A: Questionário Pesquisa Quantitativa Discente - Agropecuária 162

Apêndice B: Questionário Pesquisa Quantitativa Discente - Meio Ambiente 172

Apêndice C: Questionário Pesquisa Quantitativa Discente - Informática .173

Apêndice D: Entrevista com os Professores - 01 174

Apêndice E: Entrevista com os Professores - 02 175

Apêndice F: Entrevista com os Professores - 03 176

Apêndice G: Entrevista com os Professores - 04 177

Apêndice H: Termo de Responsabilidade Para Acesso ao Banco de Dados de Egressos do IFNMG 178

Apêndice I: Termo de Consentimento Pesquisa Discente 179 Apêndice J: Termo de Consentimento Pesquisa Docente 180 


\section{INTRODUÇÃO}

Atualmente alguns estudos realizados acerca da política pública da educação profissional técnica de nível médio integrada ao ensino médio, evidenciam um descompasso entre os dois eixos de integração que a alicerçam, geralmente com domínio da parte propedêutica sobre a parte profissionalizante, e, dessa forma, vindo a descaracterizar a política pública como um todo, uma vez que o conceito de integração da política pública pressupõe incorporar a importância de formação dos dois eixos, sem um sobrepor o outro.

Essa ênfase na parte propedêutica e a consequente perda do caráter profissionalizante na política pública do ensino integrado podem ser verificadas, como esses estudos atuais indicam, pelas expectativas e motivações discentes de um lado, e as falhas de operacionalização do estágio supervisionado como elo integrador dos dois polos da formação, por outro. Porém, esse descompasso entre os eixos já vem de muito tempo.

A história do ensino médio no Brasil é a história do enfrentamento da ambiguidade de um nível de ensino que oscila entre as finalidades de promover a educação geral e a educação profissional, ora separadas, ora articuladas, ao sabor das políticas públicas de cada período. (KUENZER,2009, p.7-8)

Historicamente, o dualismo caracterizou a relação entre a formação propedêutica e a formação profissional, atribuindo-se a esta, o caráter de formação inferior àquela. Assim, mesmo quando houve iniciativas de integrar essa formação, o pêndulo continua pendendo para o propedêutico, considerado o polo dominante dessa relação. Atualmente essa integração é regida pelo Decreto 5.154/04, anterior a esse Decreto houve uma iniciativa com Lei $n^{\circ}$ 5.692/71.

Em 1971, segundo Frigotto e Ciavatta (2006), a tentativa de integração entre propedêutico e profissionalizante, através da profissionalização compulsória no ensino secundário com a Lei $n^{\circ} 5.692$ de 11 de agosto de 1971(Governo de Emílio Garrastazu Médici), aparentemente poderia promover a superação do dualismo, 
entretanto, interesses conflituosos distintos forçaram ajustamentos, e por fim a Lei $\mathrm{n}$. $7.044 / 82$ extinguiu a profissionalização obrigatória no $2^{\circ}$ grau.

Mesmo diante das críticas que qualificavam como tecnicista a Lei 5.692/71, que inclusive determinava que houvesse a predominância da parte especial (técnica) sobre a parte geral (propedêutica), foi ressaltado pelo Instituto Nacional de Estudos e Pesquisas Educacionais, INEP (1982) que:

[...] embora seja hoje necessário redefinir a política de profissionalização do ensino de $2^{\circ}$ grau, é necessário fazê-lo de forma a não se perder uma das mais importantes conquistas, trazidas pela Lei 5.692/71: a idéia de que a formação integral do adolescente inclui necessariamente algum tipo de relação com o mundo do trabalho. (INEP, 1982, p.56)

Os pressupostos da Lei 5.692/71 foram elencados pelo, INEP (1982):

A análise histórica das funções do ensino de $2^{\circ}$ grau, no Brasil, permite inferir que a proposta de profissionalização da Lei 5.692/71, pressupõe a existência de algumas condições básicas, que são, principalmente:

- existência de relações estreitas e racionais entre escola e mercado de trabalho;

- carência de técnicos de nível médio no País;

- valorização da escolaridade formal por parte da empresa;

- possibilidade de se atribuir ao sistema educacional a maior responsabilidade pelo preparo dos recursos humanos necessários à modernização do setor econômico;

- viabilidade de uma proposta única de ensino médio para todo o País, capaz não só de integrar o desenvolvimento intelectual do adolescente com sua formação profissional, mas também de promover a regulação das novas relações surgidas - ou por surgir - entre a educação e o sistema econômico. (INEP,1982, p.82)

Para Frigotto e Ciavatta (2006), em síntese, a Lei n. 5.692/71 surgiu com um duplo propósito: 
[...] o de atender à demanda por técnicos de nível médio e o de conter a pressão sobre o ensino superior. O discurso utilizado para sustentar o caráter manifesto de formar técnicos construiu-se sob o argumento da "escassez de técnicos" no mercado e pela necessidade de evitar a "frustração de jovens" que não ingressavam nas universidades nem no mercado por não apresentarem uma habilitação profissional. Isto seria solucionado pela "terminalidade" do ensino técnico. (FRIGOTTO E CIAVATTA, 2006, p.36).

Ainda segundo Frigotto e Ciavatta (2006) com o advento da Lei n. 7.044/82, as escolas técnicas federais, voltaram a valorizar a formação por elas desenvolvida, por serem instituições mais adequadas para conferir o $2^{\circ}$ grau o caráter profissionalizante, voltado para a formação em habilitações profissionais específicas.

Pode-se dizer, então, que a partir desta lei, até o final da década de 1980, as escolas técnicas federais desempenharam sua função de formar técnicos de $2^{\circ}$ grau com qualidade, sendo reconhecidas pelas burocracias estatais e pela sociedade civil, que as isentavam de qualquer questionamento sobre seu papel econômico e social. (FRIGOTTO, CIAVATTA, 2006, p.37)

Para os autores, as escolas técnicas federais desempenharam sua função de formar técnicos de $2^{\circ}$ grau de qualidade, no entanto, estudos no período de vigência da Lei n. 7.044/82 apontaram que houve uma perda do caráter profissionalizante nas instituições federais que ofertavam o ensino profissionalizante integrado ao ensino médio, para Castro (1997) também em relação às escolas técnicas federais, a parte técnica do ensino integrado reduziu de tamanho ou foi até mesmo eliminada, foi constatado, naquele momento, que os discentes em sua maioria eram indiferentes à parte técnica da formação e só lhes interessava a parte propedêutica reconhecidamente de qualidade para melhor se prepararem a concorrer às vagas do ensino superior.

Essa constatação também é referenciada por Carvalho (2003, p.85) ao informar sobre o aspecto da redução de custos ambicionada pelo decreto 2.208/97 (que viria a proibir a integração) com a "racionalização dos recursos existentes nas escolas de educação tecnológica da rede federal, consideradas muito caras e cuja clientela, ao invés de atuar na área da profissão técnica" tinha "se voltado, prioritariamente, para o acesso ao curso superior". 
Em 17 de abril de 1997, o Decreto 2.208/97 (Governo de Fernando Henrique Cardoso) proibiu definitivamente a oferta de cursos integrados, admitindo articulação concomitante, ou seja, o aluno poderia cursar ao mesmo tempo o ensino médio e o profissionalizante, sendo este último não compulsório e de matrículas e currículos distintos, para Carvalho (2003) isso em nada contribuiu para superar a dualidade ainda existente; outro modo de articulação do ensino médio com o profissionalizante, previsto no Decreto 2.208/97 é a modalidade subsequente, quando o aluno faz o ensino técnico somente após ter concluído o ensino médio. Então, como se percebe, a educação profissional com Decreto 2.208/97 possuía uma organização curricular própria, independente do Ensino Médio.

Em 23 de julho de 2004, com o advento do decreto 5.154/04 (Governo de Luiz Inácio Lula da Silva), é retomada novamente a possibilidade de integrar o ensino médio à educação profissional técnica de nível médio, além de manter a articulação concomitante e subsequente previstas no revogado decreto 2.208/97.

O Decreto $n^{\circ} 5.154 / 04$ e toda a discussão que the deu origem (CIAVATTA; FRIGOTTO; RAMOS, 2005), permite aos distintos sistemas de educação organizar propostas de cursos que assegurem uma formação ampla, integral e, portanto, humanística, de cultura geral e técnica ao mesmo tempo, sem supremacia de uma sobre as outras, garantindo assim as condições dos estudantes para uma participação efetiva na sociedade em suas dimensões social, política, cultural e econômica, incluindo o mundo do trabalho, mas não se restringindo a ele ou a qualquer dessas dimensões isoladamente. (Baracho et al, 2006, p. 69)

O documento base (2007) define essa modalidade integrada como "Educação Profissional Técnica de Nível Médio Integrada ao Ensino Médio", e o descreve como sendo uma modalidade de ensino onde há a integração da formação básica e profissional de forma orgânica num mesmo currículo. A página de apresentação da Política Pública atenta: 
No entanto, tal política somente logrará êxito se, para além dos esforços governamentais, a sociedade civil entendê-la como necessária e adequada à formação de seus cidadãos e com ela comprometer-se, visando o enriquecimento e consolidação desse projeto. (Documento Base, 2007, p.4)

Ciavatta referenciando Gramsci (1981) explica que o sentido de integração no ensino médio integrado ao ensino técnico (ensino integrado) diz respeito em tornar inseparável a educação geral da educação profissional em todos os campos onde se dá a preparação para o trabalho, é a busca pelo foco do trabalho como princípio educativo, sob o ponto de vista da superação da dicotomia trabalho manual versus trabalho intelectual, e da incorporação da dimensão intelectual ao trabalho produtivo, para a formação de trabalhadores capazes de atuar como dirigentes e cidadãos. (CIAVATTA, 2005, p.84)

Entretanto, passados mais de dez anos do advento do decreto 5.154/04, pesquisas recentes apontam obstáculos para o êxito da modalidade integrada, ao que tudo indica o fenômeno ocorrido nas décadas de 80 e 90, encontra-se latente novamente, ou seja, os discentes das escolas técnicas federais ao invés de atuar como técnicos em sua área de formação se utilizam do ensino integrado prioritariamente para acesso ao ensino superior, implicando a perda do caráter profissionalizante da política pública.

Além dos atuais estudos acadêmicos que apontam indiferença da clientela para com o eixo profissionalizante, foi constatado também por pesquisas realizadas por órgãos do governo, Ministério da Educação (MEC), Conselho Nacional de Educação (CNE) e o Tribunal de Contas da União(TCU), um excelente desempenho das escolas técnicas federais no Exame Nacional do Ensino Médio (ENEM), mas em contrapartida foi constatado descuido com a parte profissionalizante, inclusive na operacionalização do estágio supervisionado.

O estágio supervisionado, devido as suas concepções, é forte caracterizador do eixo profissionalizante, mas acima disso é, também, um forte componente curricular capaz de como nenhum outro realmente integrar as disciplinas práticas e teóricas e promover a verdadeira experiência do discente com o mundo do trabalho que ele terá que se deparar quando nele ingressar, essa experiência favorece a socialização e o contato com profissionais experientes da área profissional, e durante 
essa experiência ainda é possível contar com o benefício da assistência da instituição educadora, auxiliando-o a se posicionar criativamente e criticamente diante do sistema produtivo. Portanto, na falta ou nas falhas de operacionalização do estágio supervisionado comprometer-se-á o caráter profissionalizante e consequentemente a formação integrada.

Tendo constatado essa situação de desequilíbrio entre eixos, nos instigou querer saber como vem sendo implementada a política pública, em especial quanto ao eixo formação para o trabalho, analisando a relação do perfil dos discentes (motivação e expectativa) e a operacionalização do estágio supervisionado, tendo em vista elaborar um produto técnico com o intuito de resgatar o caráter profissionalizante da política pública, promovendo então um melhor alinhamento da política pública nas instituições que ofertam a modalidade.

Tendo como lócus o IFNMG-Januária, a pergunta que lançamos a campo foi:

Como se expressa o caráter profissionalizante dos cursos integrados que possuem estágio supervisionado obrigatório e opcional?

Tendo como fio condutor esta indagação, foram estabelecidos os seguintes objetivos da pesquisa abaixo listados.

$\checkmark$ Objetivo Geral:

> Analisar o caráter profissionalizante dos cursos integrados do IFNMGJanuária que possuem estágio supervisionado obrigatório e opcional.

$\checkmark$ Objetivos Específicos:

$>$ Identificar os motivos que levaram os alunos a optarem pelo Ensino Técnico Integrado ao Ensino Médio no IFNMG - Campus Januária;

$>$ Identificar as expectativas dos alunos em relação a sua inserção no mundo do trabalho e/ou à continuidade dos seus estudos;

$>$ Confrontar a expectativa discente com o caminho seguido pelos alunos egressos.

$>$ Verificar com os discentes como é operacionalizado o estágio supervisionado;

Verificar os resultados advindos do estágio supervisionado nos diferentes cursos; 
Identificar o nível do caráter profissionalizante da política pública nos cursos integrados de estágio supervisionado obrigatório e não obrigatório (opcional);

> Elaborar um Produto Técnico para o IFNMG com Orientações acerca do Estágio Supervisionado a serem observadas e discutidas nos Institutos que ofertam a modalidade de ensino integrado.

Assim sendo, essa pesquisa, inicialmente, abordou a análise de estudos que revelam a experiência do ensino integrado com ênfase na motivação e expectativa da clientela e a importância do estágio supervisionado, que apontam para o fenômeno da perda do caráter profissionalizante, para em seguida, nos aproximarmos do objeto de estudo, pesquisando o fenômeno no IFNMG-Campus Januária que oferece três cursos integrados (Agropecuária, Meio Ambiente e Informática) implementados com diferentes categorias de estágio supervisionado: "obrigatório" e "não obrigatório" (opcional), desta maneira pudemos melhor entender o fenômeno que acontece com a modalidade integrada e como acontece, também confrontamos a motivação e expectativa discente com o caminho seguido pelos alunos egressos do IFNMG através de informações extraídas da pesquisa de egressos realizada pelo Instituto.

De posse das informações colhidas e analisadas a luz dos estudiosos sobre o tema, documentos legais e pesquisas sobre a temática, elaboramos um produto técnico com Orientações de Operacionalização e Implementação do Estágio Supervisionado de forma a promover um melhor alcance dos objetivos da política pública nas Instituições que ofertam a modalidade integrada.

Para o estudo desta dissertação nos apoiamos em Olgamir Francisco de Carvalho, Acácia Kuenzer, Gaudêncio Frigotto, Maria Ciavatta, Dante Henrique Moura, Claudio de Moura Castro, Selma Garrido Pimenta, Maria Socorro Lucena Lima, Cristiano Lins de Vasconcellos entre outros estudiosos, além, é claro, de análises críticas sobre pesquisas atuais e documentos legais, que regem o tema.

Sintetizando, essa dissertação se estruturou em três capítulos a saber:

No primeiro capítulo relatamos e analisamos o fenômeno da perda do caráter profissionalizante que acontece na modalidade integrada nas instituições federais profissionalizantes, desde a experiência de integração nas décadas de 80 e 90, aos dias atuais, relatando pesquisas realizadas em Institutos Federias e estudos 
realizados por órgãos do governo que informam o desinteresse da clientela pela parte profissionalizante e a pouca atenção e falhas no componente curricular estágio supervisionado.

No segundo capítulo descrevemos a pesquisa de campo realizada no IFNMGJanuária com o intuito de verificar o fenômeno acima relatado para melhor entender como ele ocorria no ensino integrado. Aplicamos questionários fechados para analisarmos o perfil dos discentes (motivação e expectativas) nos cursos onde o componente curricular estágio supervisionado é obrigatório e opcional, e a importância como era promovido esse componente curricular, também comparamos os resultados da pesquisa local com informações extraídas do banco de Dados de egressos do IFNMG a fim de conhecermos com mais exatidão o perfil e o caminho mais provável dos discentes da Instituição. Em seguida, de modo a aprofundar o entendimento, realizamos entrevistas semiestruturadas com professores que ocupam cargos de gestão e coordenação. Para tanto, utilizamos a metodologia mista de pesquisa, a explanatória sequencial proposta por Creswell (2007).

No terceiro capítulo, com base nos estudos e nos resultados da pesquisa de campo, elaboramos um produto técnico que, como dito anteriormente, descreve orientações a serem observadas e discutidas nas Instituições de ensino que ofertam a modalidade integrada para a melhoria e regulamentação do estágio supervisionado de modo que possa melhor alinhar os cursos integrados aos objetivos para qual foram criados. 


\section{CAPITULO 1}

\section{O ENSINO INTEGRADO NAS INSTITUIÇÕES FEDERAIS PROFISSIONALIZANTES: BREVE PANORAMA}

\subsection{O Ensino Integrado nas Décadas de 80 e 90}

Como dito anteriormente, o decreto 2.208/97 intercalou as duas experiências de integração propedêutico e profissionalizante, a regida pela Lei n ${ }^{\circ}$ 5.692/71 e a atual, regida pelo Decreto № $5.154 / 04$, nesse capítulo iremos tratar dos estudos que caracterizaram as duas experiências, mas antes se faz necessário uma breve contextualização.

Carvalho (2003) refletindo historicamente sobre o papel assumido pela educação profissional nos informa que tanto a concepção quanto a estrutura educacional dessa modalidade foram organizadas sob as determinações da conjuntura econômica e política dos diferentes países e, dessa forma, respondia as expectativas do mercado de trabalho, da política econômica e secundariamente as necessidades da clientela destinada a essa parcela do processo formativo.

Em relação ao Brasil a autora faz uma síntese da modalidade educação profissional desde quando se iniciou com os Jesuítas até ao Decreto 2.208/97, e nos informa que essa modalidade foi caracterizada pelo dualismo desde seus primórdios, institucionalizando-se assim, uma educação destinada aos dirigentes e outra aos trabalhadores.

Um ponto importante do levantamento feito por Carvalho (2003) para nosso estudo diz respeito à regulamentação da Lei n5.692/71 definindo a generalização da profissionalização para todos os cursos de $2^{\circ}$ grau e a iniciação profissional para os cursos em nível de $1^{\circ}$ grau. Essa medida, conforme a autora, não alcançou os resultados esperados e por isso foi promulgada em 1982 a Lei $n^{\circ} 7.044$ objetivando mudar a concepção de escola para habilitar para escola de preparação para o trabalho, denotando, em nosso entendimento, uma tentativa de adequar os resultados 
obtidos a realidade das instituições de ensino da época, uma vez que somente preparar para o trabalho é exercício bem mais simples e demanda menos investimentos e cobrança, do que habilitar profissionalmente, estrutura que era encontrada somente nas instituições federais profissionalizantes. Essa legislação e os seus pressupostos estiveram em vigor até 22 de dezembro de 1996, quando foi promulgada a nova Lei de Diretrizes e Bases da Educação Nacional - Lei n 9.394.

Ainda em Carvalho (2003) vimos que, em 1996, o MEC - Ministério da Educação e do Desporto, encaminha ao Legislativo o Projeto de Lei $n^{\circ} 1.603 / 96$, que tratava sobre a reforma da educação profissional, mas que devido a fortes críticas e ao número de emendas ao projeto, o MEC acaba substituindo-o pelo Decreto $\mathrm{n}^{\circ}$ 2.208/97, mantendo a proposta do projeto inicial. O Art. $5^{\circ}$ do Decreto $n^{\circ} 2.208 / 97$ determinava que "A educação profissional de nível técnico terá organização curricular própria e independente do ensino médio, podendo ser oferecida de forma concomitante ou sequencial a este" (BRASIL, 1997). Estava proibida então a formação integrada (propedêutico e profissionalizante em currículo único). Em relação a essa situação a autora descreve:

Observa-se, em relação ao Decreto, que embora ele admita a oferta concomitante entre o ensino médio e o ensino técnico, a separação dos tipos de ensino, evidencia que eles não integram o mesmo processo formativo, mantendo assim a dualidade até então existente.[...]Atualiza-se a antiga concepção da educação profissional, como uma alternativa de educação para os menos favorecidos, atrelada aos interesses do mercado de trabalho e descompromissada com o conhecimento teórico e prático dos trabalhadores. Tal decreto, embora se apresente como alternativa capaz de romper com a dicotomia estrutural, pois separa, em sistemas independentes, o Ensino Médio, da Educação Profissional, acaba efetivamente, por manter o referido dualismo. (CARVALHO, 2003, p.83-84)

Carvalho (2003) continua sua análise sobre o referido decreto destacando o aspecto da redução de custos que ele provocou, além de um esvaziamento das funções do Estado, transferindo essas funções para o mercado. Em suas palavras: 
Da perspectiva do Governo, esta seria atingida por meio de várias estratégias: seja pela oferta de cursos rápidos, demandados pelo mercado; seja pela racionalização dos recursos existentes nas escolas de educação tecnológica da rede federal, consideradas muito caras e cuja clientela, ao invés de atuar na área da profissão técnica tem se voltado, prioritariamente, para o acesso ao curso superior e, finalmente, com o repasse de recursos públicos para empresas privadas, para que estas assumam em lugar do Estado, a educação dos trabalhadores, o que em última instância levará ao fomento à iniciativa privada propriamente dita. (CARVALHO, 2003, p.85)

A constatação acima de Carvalho de que "as escolas de educação tecnológica da rede federal, consideradas muito caras e cuja clientela, ao invés de atuar na área da profissão técnica tem se voltado, prioritariamente, para o acesso ao curso superior", são constatadas também em outras pesquisas que retratam este cenário, no contexto da Lei $n^{\circ}$ 5.692/71 e da Lei no 7.044/82: Cunha (1998 apud Campello e Lima Filho), Kruger e Tambara (2007) e também por Castro (2005) e Castro (1997).

Segundo Campello e Lima Filho (2006, p.180) a Lei n. 5.692/71 reformou o ensino primário e secundário estabelecendo compulsoriamente a profissionalização como finalidade única para o ensino de $2^{\circ}$ grau. Em decorrência desta lei, a educação profissional deixou de estar limitada a estabelecimentos especializados. Cunha (1998 apud Campello e Lima Filho, p.180) informou que "com a implantação dessa lei, as escolas técnicas viram-se procuradas por levas de estudantes que pouco ou nenhum interesse tinham por seus cursos profissionais" e que:

Paradoxalmente, a profissionalização compulsória do ensino de $2^{\circ}$ grau trouxe como efeito o reforço da função propedêutica das escolas técnicas, que se transformaram numa alternativa de ensino público para estudantes que apenas pretendiam se preparar para o vestibular. (Cunha, 1998 apud Campello e Lima Filho, p.180)

Kruger e Tambara (2007, p.2) em sua pesquisa com o objetivo de analisar as transformações do perfil dos estudantes do Centro Federal de Educação Tecnológica de Pelotas - CEFET-RS, relata que nos anos 80 (pelos motivos que competiam na época) "que a sociedade, ao descobrir que as escolas técnicas estavam oferecendo aos seus alunos um ensino secundário, público, gratuito e reconhecidamente de alta qualidade, vê ali uma grande alternativa para seus filhos" e que o perfil do aluno naquela época em geral não tinha "o interesse de exercer a atividade de técnico, tendo 
como preocupação ingressar no Ensino Superior, usando para isso os conhecimentos adquiridos na formação de $2^{\circ}$ Grau Técnico".

Castro (2005, p.52), descrevendo o cenário do ensino integrado também em fins da década de 1980, observou que as Escolas Técnicas Federais preparavam técnicos que muito raramente se tornavam técnicos. Os discentes eram oriundos cada vez mais, segundo o autor, das classes média e alta, "e não pensavam em nada além dos vestibulares para as melhores universidades, fossem os de direito, fossem os de medicina". O mesmo autor, ainda em 1997 quando na promulgação do decreto 2.208/97, em artigo intitulado "Oficina mecânica para formar advogados?" em revista de grande circulação, relatava a deterioração da parte profissionalizante em função de uma clientela que não tinha interesse pela habilitação profissional:

Hoje, como são poucos alunos interessados nas ocupações ensinadas, a parte profissional se deteriorou. $O$ pedaço da escola técnica que contém o ensino médio acadêmico pode ter diferentes destinos. Em algumas escolas, poderá ser reduzido de tamanho, ou mesmo eliminado. Afinal, é muito gasto para uma clientela muito elitizada. (CASTRO, 1997, p.142)

\subsection{O Ensino Integrado na Vigência do Decreto ${ }^{\circ} 5.154 / 04$}

Em 23 de Julho de 2004 o Decreto $n^{\circ} 5.154 / 04$ estabeleceu a possibilidade de integrar novamente o ensino médio à educação profissional técnica de nível médio além de manter as ofertas dos cursos técnicos concomitantes e subsequentes trazidas pelo Decreto $n^{\circ} 2.208 / 97$, que como vimos na seção anterior havia proibido a integração. $O$ art. $1^{\circ}$ do decreto 5.154/04 traz: "A educação profissional técnica de nível médio [...] será desenvolvida de forma articulada com o ensino médio". (BRASIL, 2004)

Quanto aos modos de articulação define: 
$\S 1$ 1 A articulação entre a educação profissional técnica de nível médio e o ensino médio dar-se-á de forma:

I- integrada, oferecida somente a quem já tenha concluído o ensino fundamental, sendo o curso planejado de modo a conduzir o aluno à habilitação profissional técnica de nível médio, na mesma instituição de ensino, contando com matrícula única para cada aluno;

II - concomitante, oferecida somente a quem já tenha concluído o ensino fundamental ou esteja cursando o ensino médio, na qual a complementaridade entre a educação profissional técnica de nível médio e o ensino médio pressupõe a existência de matrículas distintas para cada curso, podendo ocorrer:

a) na mesma instituição de ensino, aproveitando-se as oportunidades educacionais disponíveis;

b) em instituições de ensino distintas, aproveitando-se as oportunidades educacionais disponíveis; ou

c) em instituições de ensino distintas, mediante convênios de intercomplementaridade, visando o planejamento e $o$ desenvolvimento de projetos pedagógicos unificados;

III - subseqüente, oferecida somente a quem já tenha concluído o ensino médio. (BRASIL, 2004)

Essa proposta se apresentou como uma nova esperança para romper com a dicotomia estrutural, com o dualismo presente até o Decreto $n^{\circ} 2.208$, que historicamente tem sido imposta aos estudantes da classe trabalhadora como já explicitado por Carvalho (2003), uma nova concepção, alinhada aos anseios dos que vivem do trabalho. Assim se expressa Kuenzer (2001):

Elaborar e disponibilizar aos jovens que vivem do trabalho a nova síntese entre o geral e o particular, entre o lógico e o histórico, entre a teoria e a prática, entre o conhecimento, o trabalho e a cultura. (KUENZER, 2001, p.43-44).

Porém, contraditoriamente ao plano legal e a produção teórica que avançava para a integração, houve a separação estrutural entre educação básica e profissional. Moura (2010) ao explanar sobre as possibilidades de implementação do ensino médio Integrado com o advento do Decreto 5.154/04 nos atenta sobre esse paradoxo: 
As duas possibilidades de ensino médio integrado são conceitual e legalmente viáveis. Entretanto, o processo histórico é, por vezes, contraditório e construído a partir da atuação dos distintos sujeitos, classes sociais e grupos de interesse e das correlações de forças entre eles. Assim, exatamente quando no plano legal o Decreto $\mathrm{n}^{\circ} 5.154 / 04$ possibilitou a integração do ensino médio aos cursos técnicos, a estrutura do MEC foi alterada: criou-se a Secretaria da Educação Básica (SEB) e a Secretaria de Educação Profissional e Tecnológica (SETEC), a partir do desmembramento da Secretaria de Educação Média e Tecnológica (SEMTEC). Dessa forma, enquanto no plano legal e na produção teórica se avançava para a integração, a estrutura, contraditoriamente, apontava para a separação entre educação básica e profissional. (MOURA, 2010, p.4)

Estruturas independentes, num contexto que historicamente se valoriza a formação propedêutica, pode não colaborar para o equilíbrio dos eixos da formação integrada.

Moura (2010) delineando sobre o ensino médio (regular) atual, nos diz que, no Brasil, grande parte das escolas particulares adota uma concepção equivocada ao substituir o todo (a formação integral) pela parte (prosseguimento de estudos via aprovação no vestibular) ao concentrar seus esforços nesse último, e que, por outro lado, as escolas públicas tentando reproduzir o mesmo academicismo e sem ter a mesmas condições materiais para isso, acabaram realizando uma formação que não se mostra efetiva para o ingresso digno no mundo do trabalho, e nem é muito significativa quanto ao eixo prosseguimento dos estudos em nível superior. Para o autor, esta é uma orientação perversa.

Amparado pelos dados do INEP de que a maioria dos cidadãos brasileiros não prossegue os estudos em nível superior, e atua profissionalmente com um nível de escolarização que não ultrapassa a educação básica, Moura afirma que o ensino médio e seu êxito não podem limitar-se, como ocorre na maioria dos casos, a constituir-se em ponte entre o ensino fundamental e a educação superior.

Considerada a afirmação de Moura (2010), de que a maioria dos cidadãos brasileiros não prossegue os estudos em nível superior, e atua profissionalmente com um nível de escolarização que não ultrapassa a educação básica; não seria coerente esperar que as vagas no ensino integrado, que são escassas se comparadas às vagas do ensino médio regular, sejam absorvidas pela clientela que necessite da 
profissionalização após o término do ensino médio, já que buscam atuar no mercado de trabalho com instrução de nível médio?

Porém, como também afirmou ou autor, as escolas públicas tentam reproduzir o mesmo academicismo das escolas particulares e, de fato, isso nos parece verdade até mesmo nas instituições técnicas federais que ofertam o ensino médio integrado ao ensino técnico, pois, pesquisas sobre o ensino integrado pós-decreto 5.154/04 evidenciam o mesmo fenômeno ocorrido na vigência da Lei $n^{\circ}$ 5.692/71 apontado por Carvalho (2003) e as pesquisas da época, ou seja, os discentes adentram no ensino integrado prioritariamente pelo ensino propedêutico de qualidade para melhor se prepararem a concorrer às vagas no ensino superior, reforçando as características propedêuticas em detrimento da parte profissionalizante, ocasionando a perda do caráter profissionalizante da política pública.

Como salientado por Moura (2010) o ensino médio regular não pode constituirse em mera ponte entre o ensino fundamental e a educação superior, logo entendemos que o ensino integrado menos ainda. Se as escolas que oferecem o ensino profissionalizante integrado ao ensino médio não estiverem formando a clientela interessada em profissionalização de ensino médio, além de reduzirmos os objetivos da política pública, fatalmente não conseguiremos formar profissionais em qualidade e quantidade suficientes para o país.

De acordo com o Mapa do Trabalho Industrial 2012, elaborado pelo SENAI e disponível na internet, o Brasil precisará formar 7,2 milhões de trabalhadores em nível técnico até 2015 (sendo 1,1 milhão para novas oportunidades e o restante em treinamentos de qualificação para os que já estão trabalhando). O diretor de Educação e Tecnologia da CNI, Rafael Lucchesi (no mesmo artigo da página) afirmou que somente $6,6 \%$ dos brasileiros com idades entre 15 a 19 anos estão em cursos de educação profissional e que na Alemanha, esse índice é de $53 \%$, e atenta que os jovens brasileiros precisam ver a formação profissional como uma excelente oportunidade para o mercado de trabalho. 


\section{MAPA DO TRABALHO INDUSTRIAL 2012}
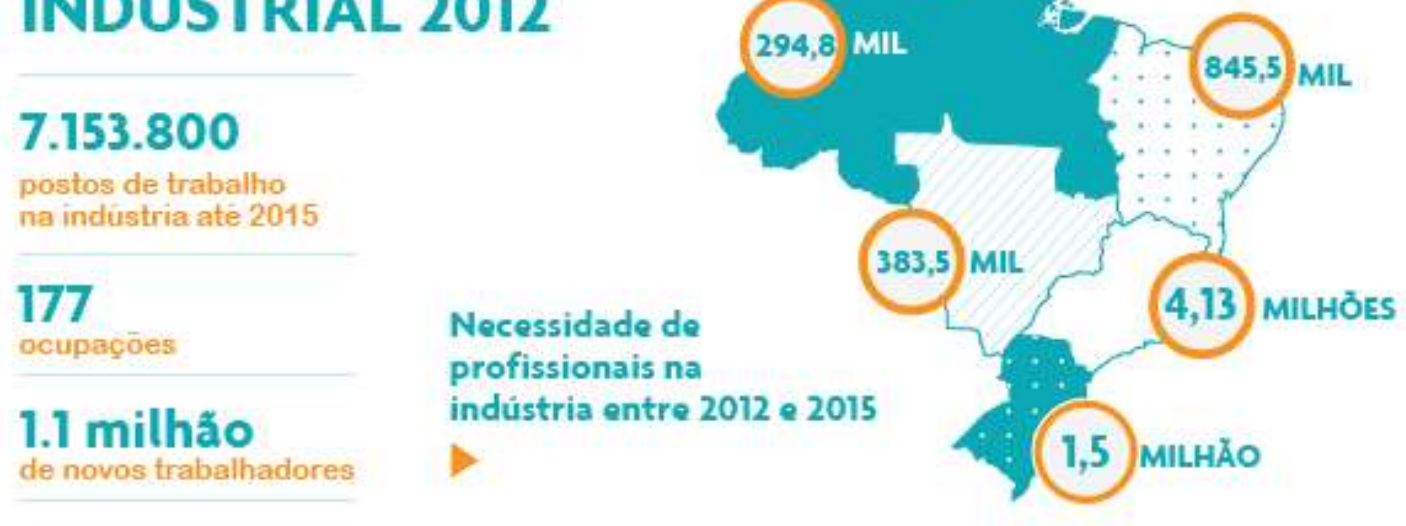

Fonte: Sítio da Agência FIEP1

Como vimos anteriormente, Castro (1997) relatou que a parte técnica do ensino integrado, nas décadas de 80 e 90, ou reduziu de tamanho ou foi eliminada, atualmente também podemos observar esse mesmo comportamento nas instituições que lidam com o ensino integrado. Valaski (2012), por exemplo, observou em sua pesquisa sobre o Ensino Integrado no Paraná que o estágio supervisionado teve sua importância diminuída, colocando-o como opcional, para não sobrecarregar os alunos que possuíam interesse prioritário no ingresso do ensino superior.

O estágio então, segundo Valaski (2012, p.43) "passa a ser uma possibilidade, uma escolha do aluno", o que nos indica que a instituição diante da demanda da clientela ingressante influenciou-se, descaracterizando o eixo formação profissional da política pública em favor do eixo propedêutico.

Estudos mais abrangentes, completos e específicos com o tema estágio supervisionado foram realizados pelo TCU (Tribunal de Contas da União) e também pelo Conselho Pleno e CNE (Conselho Nacional de Educação) em parceria com a UNESCO - Organização das Nações Unidas para Educação, Ciência e Cultura. Esses estudos apontam deficiências no modo como vem sendo tratado o estágio 
supervisionado nas Instituições de ensino, o que acaba por comprometer a parte profissionalizante. Detalhes desses estudos serão descritos mais à frente.

Essas análises são interessantes porque, ainda mais no cenário econômico nacional que nos encontramos, devido ao alto investimento que demanda a política pública do ensino integrado, é inadmissível reduzirmos a política pública a bons resultados a um só eixo (o propedêutico), ignorando, em grande parte, todo o investimento no eixo profissionalizante. Continuando dessa maneira o ensino integrado perde o sentido.

Segundo Pinto, Amaral e Castro (2011) o valor aplicado por aluno na educação básica nas instituições federais foi de $\mathrm{R} \$ 10.525$ em 2008 , vale lembrar que a oferta de ensino integrado aumentou consideravelmente após o ano de 2008 devido à expansão da Rede com os Institutos Federais, demandando maiores investimentos financeiros.

No mesmo sentido, Castro (1997), questionou o alto custo do aluno da escola técnica federal (nas décadas de 80 e 90), citando, por exemplo, um aluno que faz cursos nada compatíveis, como curso técnico em Mecânica e vestibular para Medicina ou Direito, e assim pontua:

[...] dois terços dos graduados das escolas técnicas vão para o ensino superior. São escolas caríssimas, próximo de 5.000 reais por aluno, oferecendo um esplêndido ensino de $2^{\circ}$ grau. Todos entenderam isso e competem para entrar, sobretudo porque é de graça. Ficam as indústrias sem os técnicos de que precisam para serem competitivas, e ficam a ver navios os alunos mais modestos, interessados nas ocupações técnicas oferecidas. (Castro, 1997, p.142)

A compatibilidade de cursos técnico e superior requerida por Castro (1997) nas décadas de 80 e 90 é objetivo da política pública do ensino integrado atual, conhecida como itinerário formativo.

Essas e outras questões serão melhor compreendidas ao discutirmos na próxima seção os objetivos da política pública e a missão dos Institutos Federais para melhor confrontar o status quo do ensino integrado com os objetivos que a política pública visa alcançar. 


\subsection{Os Institutos Federais}

Antes de analisarmos os estudos sobre o caráter profissionalizante da política pública do ensino integrado atualmente, é interessante conhecer um pouco da missão e objetivos dos institutos federais (alvo do nosso estudo) que ofertam o ensino integrado, dessa forma podemos melhor comparar a missão dos Institutos e os objetivos do ensino integrado (que os institutos federais por Lei devem ofertar) com os resultados desses estudos sobre o tema.

Dentro do contexto do Decreto 5.154/04 e dos ideais para o ensino integrado, foram criados os Institutos Federais de Educação, Ciência e Tecnologia, sua Lei de Criação é a LEI No 11.892, de 29 de Dezembro de 2008, instituindo a Rede Federal de Educação Profissional, Científica e Tecnológica.

Art. $1^{\circ}$ Fica instituída, no âmbito do sistema federal de ensino, a Rede Federal de Educação Profissional, Científica e Tecnológica, vinculada ao Ministério da Educação e constituída pelas seguintes instituições:

I - Institutos Federais de Educação, Ciência e Tecnologia Institutos Federais;

II - Universidade Tecnológica Federal do Paraná - UTFPR;

III - Centros Federais de Educação Tecnológica Celso Suckow da Fonseca - CEFET-RJ e de Minas Gerais - CEFET-MG;

IV - Escolas Técnicas Vinculadas às Universidades Federais.

IV - Escolas Técnicas Vinculadas às Universidades Federais; e (Redação dada pela Lei $n^{\circ} 12.677$, de 2012)

V - Colégio Pedro II. (Incluído pela Lei $n^{\circ} 12.677$, de 2012)

(LEI No 11.892, DE 29 DE DEZEMBRO DE 2008)

Segundo o sítio da Rede Federal muitas dessas novas instituições já existiam com outra denominação. 
Em 29 de dezembro de 2008, 31 centros federais de educação tecnológica (Cefets), 75 unidades descentralizadas de ensino (Uneds), 39 escolas agrotécnicas, 7 escolas técnicas federais e 8 escolas vinculadas a universidades deixaram de existir para formar os Institutos Federais de Educação, Ciência e Tecnologia. (Sítio da Rede Federal $^{2}$ )

Como vimos, após o decreto 2.208 não se podia oferecer o ensino médio de forma integrada, somente era possível na forma subsequente ou concomitante, mas a LEI 5.154/04 retomou a possibilidade da oferta da modalidade integrada, e com a criação dos Institutos Federais essa modalidade ganhou espaço e prioridade, como podemos observar nos objetivos dos Institutos Federais na Seção III da Lei de Criação:

Art. 7ㅇ Observadas as finalidades e características definidas no art. 6 desta Lei, são objetivos dos Institutos Federais:

I - ministrar educação profissional técnica de nível médio, prioritariamente na forma de cursos integrados, para os concluintes do ensino fundamental e para o público da educação de jovens e adultos;(LEI No 11.892, DE 29 DE DEZEMBRO DE 2008)

Pacheco (2011) explicita mais sobre a missão dos Institutos Federais:

Na educação profissional e tecnológica (EPT), a instalação, entre 2003 e 2010, de 214 novas escolas vem ampliar a Rede Federal na perspectiva de colaboração com os demais sistemas de ensino para fortalecimento da oferta de EPT e, ao mesmo tempo em que criou os Institutos Federais de Educação, Ciência e Tecnologia, autarquias federais que tem a missão institucional a formação profissional, ofertada em itinerário formativo, possibilitando ao ingressante cursar desde cursos de formação inicial e continuidade até a pós-graduação. Aos institutos é dada a missão de promover o desenvolvimento regional, aliando ensino, pesquisa e extensão. (PACHECO org.,2011, p.6)

Atentemos para o itinerário formativo, pois ele permeia diretamente o ensino integrado. O documento "Institutos Federais Lei 11.892, de 29/12/2008 Comentários

${ }^{2 h t t p: / / r e d e f e d e r a l . m e c . g o v . b r / h i s t o r i c o ~}$ 
e Reflexões" veiculado pelo MEC, organizado por Caetana Juracy Rezende Silva, traz diversos esclarecimentos sobre a missão dos Institutos Federais, entre eles vemos novamente a preocupação com o itinerário formativo:

$\mathrm{Na}$ construção de seus projetos pedagógicos, visando o cumprimento da missão para que foram criados, os institutos federais deverão adotar como diretrizes:

a necessidade de atuar no ensino, na pesquisa e na extensão, compreendendo as especificidades destas dimensões $e$ as interrelações que caracterizam sua indissociabilidade;

[...] a compreensão da pesquisa ancorada nos princípios científico - que se consolida na construção da ciência e desenvolvimento da tecnologia - e no educativo - que diz respeito à atitude de questionamento diante da realidade -, entendendo-a como essencial para a construção da autonomia intelectual e, portanto, potencializadora de uma educação que possibilita ao indivíduo o desenvolvimento de sua capacidade de gerar conhecimentos a partir de uma prática interativa com a realidade;

a compreensão de que o conhecimento deve ser tratado em sua completude, nas diferentes dimensões da vida humana, integrando ciência, tecnologia, cultura e conhecimentos específicos inclusive nas propostas pedagógicas dos cursos de graduação (licenciaturas, engenharias e superiores de tecnologia) e pósgraduação - na perspectiva de ultrapassar o rígido limite traçado pelas disciplinas convencionais;

a concepção das atividades de extensão como forma de diálogo permanente e mais amplo com a sociedade;

o reconhecimento da precedência da formação humana e cidadã, sem a qual a qualificação para o exercício profissional não promove transformações significativas para o trabalhador e para o desenvolvimento social;

a necessidade de assegurar aos sujeitos as condições de interpretar a sociedade e exercer sua cidadania, na perspectiva de um país fundado na justiça, na equidade e na solidariedade;

[continua] 
a organização de itinerários formativos que permitam o diálogo entre os diferentes cursos da educação profissional e tecnológica (formação inicial e continuada, técnica de nível médio e de graduação e pós-graduação tecnológica), ampliando as possibilidades de formação vertical (elevação de escolaridade) e horizontalmente (formação continuada);

a sintonia dos currículos com as demandas sociais, econômicas e culturais locais, permeando-os das questões de diversidade cultural e de preservação ambiental, pautada na ética da responsabilidade e do cuidado;

o reconhecimento do trabalho como experiência humana primeira, organizadora do processo educativo. (SILVA org., 2009, p.10)

Sendo assim, quanto ao itinerário formativo, espera-se, por exemplo, que caso um aluno curse o técnico em informática, e opte em não trabalhar como técnico e sim seguir a carreira de nível superior, prossiga os estudos em cursos como Tecnologia em Análise e Desenvolvimento de Sistemas, Bacharelado em Sistemas de Informação, Licenciatura em Computação, Ciência da Computação e outros de mesma área da formação técnica.

Dos objetivos pertinentes ao estudo desta dissertação destacamos os seguintes do Documento Base da Educação Profissional Técnica de Nível Médio Integrada ao Ensino Médio:

Como síntese, apresentamos alguns pressupostos que os sistemas e instituições devem considerar para a elaboração do projeto político pedagógico do ensino médio integrado à educação profissional, apropriados de Ciavatta (2005), com os quais compartilhamos:

a) Não reduzir a educação às necessidades do mercado de trabalho, mas não ignorar as exigências da produção econômica, como campo de onde os sujeitos sociais retiram os meios de vida. Em conseqüência, é importante considerar os estudos locais, a identificação das oportunidades ocupacionais, as tendências da dinâmica sócio produtiva local, regional, nacional e global.

[continua] 
b) Construir e contar com a adesão de gestores e educadores responsáveis pela formação geral e da formação específica, bem como da comunidade em geral. É preciso discutir e elaborar coletivamente as estratégias acadêmico-científicas de integração. Tanto os processos de ensino-aprendizagem, como os de elaboração curricular devem ser objeto de reflexão e de sistematização do conhecimento através das disciplinas básicas e do desenvolvimento de projetos que articulem o geral e o específico, a teoria e a prática dos conteúdos, inclusive com o aproveitamento de aprendizagens que os ambientes de trabalho podem proporcionar (visitas, estágios etc.). (grifo nosso)

c) Articular a instituição com familiares dos estudantes e a sociedade em geral. As experiências de formação integrada não se fazem no isolamento institucional. A escola deve levar em conta a visão que os alunos têm de si mesmos; as possibilidades de inserção social e profissional que o mundo externo lhes oferece; as modalidades formativas oferecidas pela escola. Isso exige um processo de diálogo e de conscientização dos alunos e de suas famílias sobre as próprias expectativas e sua possível realização. (grifo nosso)

e) Transformar o projeto de formação integrada em uma experiência de democracia participativa e de recriação permanente. Ela não ocorre sob o autoritarismo, porque deve ser uma ação coletiva, já que o movimento de integração é, necessariamente, interdisciplinar. Requer que os professores se abram à inovação, a temas e experiências mais adequados à integração. Idéias em curso nas escolas são, por exemplo, projetos que articulam arte e ciência; projetos de iniciação científica; componentes curriculares voltados para a compreensão dos fundamentos sócio-políticos da área profissional, dentre outros. Há que se dar ao aluno horizontes de captação do mundo além das rotinas escolares, dos limites estabelecidos e normatizados da disciplina escolar, para que ele se aproprie da teoria e da prática que tornam o trabalho uma atividade criadora, fundamental ao ser humano. (DOCUMENTO BASE, 2007, p.55, grifo nosso)

Vimos que os estudiosos do assunto, os documentos que norteiam a política pública do ensino integrado e a missão e objetivos dos institutos federais, enfatizam a importância entre o geral e o específico, a teoria e a prática dos conteúdos (sem um sobrepor o outro), e a importância da extensão do ato educativo para além do ambiente escolar; porém, pesquisas atuais apontam fragilidades no eixo profissionalizante que devem ser analisadas e sanadas para que de fato alcancemos o êxito da política pública integralmente.

Essas pesquisas, esses estudos, que trataremos a seguir, apontam que 0 fenômeno ocorrido nos anos 80 e 90 está latente novamente nas instituições federais que ofertam o ensino integrado, ou seja, as vagas estão sendo absorvidas por um 
público que tem como principal interesse somente o ensino médio para melhor se prepararem a disputar o acesso ao ensino superior, apontam também falhas de operacionalização do estágio supervisionado. Dessa forma corroborando com as colocações de Castro (1997, p.142) de que "ficam as indústrias sem os técnicos de que precisam para serem competitivas, e ficam a ver navios os alunos mais modestos, interessados nas ocupações técnicas oferecidas", e, continuamos acrescentando que, os alunos mais modestos ficam também sem um ensino propedêutico reconhecidamente de qualidade das instituições federais, prejudicando seu desenvolvimento social e econômico.

\subsection{Relatos da Modalidade Integrada nos Institutos Federais}

Jesus, E. e Jesus, V. (2013) ao analisar o perfil dos alunos ingressantes no ano de 2013 nos cursos integrados e Concomitante do IFSP - Bragança Paulista assim atenta o leitor quanto à impressão que tiveram em sua pesquisa:

Algumas observações realizadas a partir do presente estudo sugerem que se estabeleça desde já um estado de alerta, no sentido de avaliar a necessidade de mudanças e/ou adaptações não só no perfil dos cursos oferecidos, bem como no perfil do público alvo a ser alcançado, uma vez que se observam indícios que a estrutura atual não garante necessariamente que os alunos ingressantes concluam o curso ou atuem na área de formação dos respectivos cursos. (JESUS, E.; JESUS, V,2013, p.27)

Jesus, E. e Jesus, V. (2013) analisando os dados do curso integrado em mecânica, observou que cerca de $48 \%$ dos estudantes sugerem que não seguirão carreira no técnico, e que deste montante $59 \%$ declararam abertamente que estão cursando o técnico em uma instituição federal objetivando basicamente o preparo para o ingresso em um curso superior, e reflete:

Tais resultados remetem à reflexão sobre a viabilidade dos investimentos empenhados por parte do governo na criação e manutenção dos cursos técnicos integrados puramente institucionais 
e o efetivo retorno desses investimentos em termos de alcance dos objetivos almejados pelo governo, quais sejam o abastecimento do mercado de trabalho com profissionais técnicos de nível médio; uma vez que boa parte desses alunos frequentam os cursos técnicos oferecidos pelas instituições federais objetivando principalmente uma boa formação que possibilite imediato ingresso na universidade. (JESUS, E.; JESUS, V,2013, p.32)

Anjos (2013) pesquisando sobre a opção pelo ensino médio integrado dos alunos do Instituto Federal de Educação, Ciência e Tecnologia do Norte de Minas Gerais - Campus Salinas, trouxe também suas contribuições.

A pesquisadora, num primeiro momento realizou um grupo focal e em seguida aplicou um questionário quantitativo aos discentes dos cursos integrados daquela Instituição. É relatado em sua pesquisa que quando perguntou se a instituição oferecesse só o Ensino Técnico independente do Ensino Médio, se mesmo assim, eles o cursariam, os estudantes responderam unanimemente que não cursariam se Ihes fosse oferecido apenas o curso técnico, e complementa com a fala de um aluno: "Eu não cursaria porque depois do ensino médio eu nunca pretenderei trabalhar na área técnica. Eu daqui quero ir direto para a faculdade". (L, 17 anos, $2^{\mathrm{a}}$ série apud Anjos, 2013, p.64).

Quando questionados sobre a opção contrária, os alunos responderam que cursariam somente o ensino médio caso houvesse a possibilidade.

A parte quantitativa da pesquisa de Anjos (2013) acompanhou a tendência por ela obtida na parte qualitativa, em certo ponto a pesquisadora chega à seguinte conclusão:

Pode-se interpretar esses números a partir da ideia de que esses adolescentes buscaram o EMI no IFNMG - Campus Salinas principalmente pela necessidade de concluir o Ensino Médio. Esses dados levam à hipótese de que, se a instituição oferecesse apenas o Ensino Médio de forma concomitante, provavelmente a grande maioria cursaria, mesmo que este não viesse acompanhado de uma habilitação técnica. (ANJOS, 2013 p. 111-112)

Do exposto acima fica evidente que o interesse maior dos alunos, naquela Instituição, é somente a parte propedêutica, logo, corroborando com a ideia propagada nos anos 80 e 90 , de que as escolas técnicas federais não estariam 
cumprindo seu objetivo primeiro de formar técnicos especializados, uma vez que o interesse dos alunos era somente o ensino propedêutico de qualidade.

Rodrigues (2011) em sua investigação sobre evasão escolar no curso técnico em informática integrado ao ensino médio do Instituto Federal de Educação, Ciência e Tecnologia do Tocantins - Campus Paraíso, constatou que os alunos concluintes eram oriundos de escolas públicas enquanto os evadidos eram oriundos de escolas particulares, e que os alunos concluintes entrevistados falaram de sua total dedicação e compromisso com o curso, enquanto que os alunos evadidos mencionaram não estar comprometidos com o curso por falta de identificação com o mesmo.

Da pesquisa de Rodrigues (2011) vale ressaltar que a falta de identificação com o curso foi até mesmo motivo para evasão, ou seja, o perfil do aluno que ingressou não era compatível com os objetivos da modalidade integrada.

Loponte (2010), em sua tese "Juventude e educação profissional: um estudo com os alunos do IFSP" pesquisou a relação entre a educação profissional e juventude, no âmbito da educação profissional de nível médio, tendo como referência os interesses da juventude, a respeito da sua trajetória e da expectativa que manifestam entre a escola e o futuro. Os sujeitos da pesquisa foram os estudantes do Instituto Federal de Educação, Ciência e Tecnologia de São Paulo (IFSP), antigo CEFET-SP, quatro turmas (sendo duas de integrado). Quanto às expectativas de futuro a autora chegou à seguinte conclusão:

[...] os resultados demonstraram que os alunos pretendem fazer um curso superior mesmo diante do curso técnico concluído e de já possuírem uma profissão. Esse foi um resultando bastante relevante na pesquisa, pois reflete um cenário de descompasso entre aquilo que propõe a lei e aquilo que de fato ambicionam os jovens que buscam ensino profissionalizante e público no IFSP. (LOPONTE, 2010, p.171)

Verifica-se na tese de Loponte (2010) que essa pretensão que o aluno tem de fazer um curso superior mesmo diante do curso técnico concluído e de já possuírem uma profissão, é maior no curso integrado, pois a pesquisadora relatou que: 
[...]73,5\% dos alunos do ensino integrado frequentaram escola particular antes do curso técnico. Nesse sentido, podemos concluir que a família já possuía recursos financeiros para manter os filhos em escola particular e que provavelmente não necessitaria que o filho começasse a trabalhar tão logo concluísse o curso técnico, incentivando assim a sua entrada em um curso superior. (LOPONTE, 2010, p.164)

Portanto, dessa parte da pesquisa de Loponte (2010), verifica-se que o perfil do discente foi definitivo para caracterizar o descompasso entre as propostas da lei e o que de fato ambicionam os jovens no IFSP, como afirmou a própria autora.

Ainda em Loponte (2010, p.112) é interessante ressaltar que nos cursos integrados houve maior incidência de respostas nas opções "discordo totalmente" e "discordo parcialmente" para a afirmação de que o curso enfatize mais a prática do que a teoria, e pontua:

Ao discordarem da afirmação de que o curso enfatiza mais a parte prática do que a parte teórica, os alunos estão afirmando que as atividades do curso são desenvolvidas com abordagens mais teóricas do que práticas. Essa é, de fato, uma característica dos cursos integrados, principalmente para as turmas de primeiro e de segundo ano, que é o adiantamento dos alunos pesquisados. (LOPONTE,2010, p.112)

Santos (2011, p.140) analisou o modelo de desenvolvimento de estágio adotado pela Escola Agrotécnica Federal de Colorado do Oeste-RO, especificamente, no curso Técnico Integrado, com Habilitação em Agropecuária e suas implicações na formação profissional do aluno. Entretanto, verificou que a Instituição por oferecer somente o Ensino Integrado estava formando Técnicos Agrícolas que "em sua maioria que não pretendem exercer a profissão". Para a pesquisadora "a maioria cursa o técnico apenas visando uma formação geral melhor que lhe prepare para o vestibular, para o ingresso no nível superior" e que inclusive, esse foi o fator preponderante para a escolha do curso. 
O reflexo de que muitos estão mais interessados em um ensino médio de melhor qualidade para ingressar no nível superior, está nas suas intenções para depois de concluído o curso e no percentual insignificante que pretende atuar na profissão. Pois apenas $1,25 \%$ afirmou que pretende atuar como Técnico Agrícola e 2,5\% que pretendem tanto atuar como técnico como dar continuidade aos estudos na área, $46,25 \%$ que pretendem continuar os estudos em curso superior na área agropecuária, já $48,75 \%$ que pretendem dar continuidade aos estudos em curso não relacionado à área e 1,25\% que pretende continuar os estudos dentro e fora da área. (SANTOS, 2011, p.139)

Quanto ao estágio supervisionado Santos (2011) o caracterizou como formal e burocrático, desprovido de planejamento, acompanhamento, supervisão e avaliação de resultados, cuja importância centra-se no cumprimento da carga horária.

Pôde-se constatar que a Escola vem negligenciando sua tarefa de dar o estágio a conhecer tanto à concedente quanto ao aluno, não traduzindo o estágio como uma fonte de aprendizagem a esses atores. A Escola pouco tem informado seu alunado sobre o que vem a ser estágio e qual seu objetivo antes de iniciar essa atividade, deixando de orientá-lo para a leitura dessa realidade. Essa falta de informação e de conhecimento, gera a falta de consciência do desenvolvimento do estágio, de suas premissas e objetivos, levando ao precário desempenho dos respectivos papéis. (SANTOS, 2011, p.159)

Interessante essas duas características marcantes do estudo de Santos (2011), um insignificante percentual que pretende atuar na profissão, como disse a autora (embora esta pesquisa evidencie uma certa coerência na escolha dos alunos, porque eles pretendem ingressar em cursos superiores relacionados ao curso técnico) acompanhado de um estágio supervisionado com graves falhas de operacionalização.

O estágio supervisionado, é um componente curricular que por definição e natureza de suas atividades, deveria ser mais valorizado no ensino integrado, é através dele que o aluno pode perceber mais claramente a integração das disciplinas teóricas e práticas aplicadas na sua área profissional e de ter o contato real com o mundo do trabalho, a troca de experiências, o contato com os profissionais do ramo, etc., mas estranhamente parece ser o elemento que as instituições menos valorizam na modalidade, e sendo intrínseco a habilitação profissional, a sua falta ou a sua merecida atenção, consequentemente colabora para descaracterização do eixo 
profissionalizante da política pública e a falta de identidade do discente com a profissão, pois como afirma BURIOLLA (2001, p.13) "o estágio é o lócus onde a identidade profissional do aluno é gerada, construída e referida".

Na pesquisa de Valaski (2012) intitulada "Ensino Médio Técnico Integrado no Paraná: formação e qualificação enquanto Política Pública" a opção em "sacrificar" o estágio supervisionado se deu por opção da Instituição ao atender a demanda da clientela que ingressou no ensino integrado por interesse em cursar um ensino médio (disciplinas propedêuticas) de qualidade para melhor se prepararem para disputar o acesso no ensino superior.

Valaski (2012), tendo como objeto de estudo o Instituto Federal do Paraná (IFPR), no intuito de compreender a situação do Ensino Técnico Integrado da Instituição, perguntou aos alunos se eles optariam em fazer o Ensino Médio sem o técnico no IFPR, e verificou que 43 alunos (70,49\%) optariam pelo ensino regular, no IFPR, em lugar de procurar outra instituição para fazer o curso técnico. Demonstrando claramente, para a autora, que os alunos buscam a qualidade do ensino, mais do que a especificidade de um curso técnico, e concluiu que:

Foi possível mensurar que a escolha dos estudantes pelo Ensino Médio Técnico Integrado está fortemente relacionada com a qualidade do ensino encontrada naquela instituição e que o curso não precisaria ser necessariamente técnico. Portanto, a escolha profissional está em segundo plano, embora existam alguns relatos mostrando que a preocupação com o mercado de trabalho também está presente, em menor intensidade. (VALASKI, 2012, p.56)

A pesquisadora observou também que embora a instituição, em alguns momentos, ressalte a preocupação com o mercado de trabalho, paradoxalmente constrói um currículo de apenas três anos, atendendo aos alunos que estão buscando prosseguimento nos estudos (curso superior) e não a parte prática, que poderia ser contemplada em um currículo de quatro anos com a implementação do estágio supervisionado, e que em alguns cursos não é obrigatório, "permite-se que o aluno não tenha esse aprendizado prático, também prejudicado pela deficiência dos laboratórios. $\mathrm{E}$ ao se fazer isso, forma-se um aluno técnico mesmo sem a parte prática”. (VALASKII, 2012, p.57) 
A pesquisadora observou que "existe uma preocupação em não sobrecarregar o aluno com o estágio, pois ele talvez esteja mais preocupado em ir para a faculdade, do que para o mercado de trabalho". (VALASKII, 2012, p.43).

[...] eles são todos incentivados a fazer o estágio. A gente até queria tornar obrigatório, mas tornando obrigatório só com três anos de curso, você tira todas as chances de ele fazer um vestibular. Então, ao abrir a possibilidade de estágio, tem acompanhamento de estágio, tem todo o procedimento, só que ele não é obrigatório. Mas só a longo prazo a gente vai ver se isso dá resultado ou não. (Coordenadora do curso de Mecânica, março 2012 apud VALASKII, 2012, p.43)

Sobre a não obrigatoriedade do estágio supervisionado Valaski (2012) pondera:

Se, por um lado essa não obrigatoriedade do estágio retrata uma preocupação com o aluno, que precisa dar conta de um currículo de Ensino Médio e técnico em três anos, com aulas no contra turno; por outro, é importante problematizar como essa ausência do estágio obrigatório pode ser prejudicial, uma vez que esse período de prática constitui um importante meio de conhecimento e aprendizagem profissional na vida dos alunos. (VALASKI, 2012, p.43, grifo nosso)

Valaski (2012, p.49) identificou ainda em sua pesquisa que "os alunos dos cursos nos quais o estágio não é obrigatório, não buscam o mercado de trabalho, nesta fase de suas vidas".

No curso Técnico em Contabilidade Integrado do IFPR o estágio supervisionado é obrigatório, e o coordenador do curso, relatado por Valaski (2012, p.43), corrobora em sua preocupação na questão da importância do estágio supervisionado, citando as palavras do coordenador: "[...] isso aí é um controle que a gente tem, porque sem o estágio obrigatório não há formação. Então é um prérequisito, a pessoa tem que fazer".

Valaski (2012, p.44) atenta que, "no entanto, convém ressaltar que o ensino em três anos é uma opção da instituição, para se adaptar a uma realidade e a uma demanda local", referenciando o coordenador do curso descreve: 
[...] a gente tem um alto índice de aprovação né (sic). No vestibular. Pela carga horária teria ministrado isso em cinco anos. Só que tem um levantamento interno que diz o seguinte, aliás em quatro anos, se faz em três anos hoje. As aulas começam às $7 \mathrm{~h} 15$ da manhã e vai (sic) até $12 \mathrm{~h} 30$. Isso já é bem puxado e algumas turmas têm aula, seria no contra turno, para conseguir suprir isso. Agora, porque isso? Justamente pela necessidade do curitibano. (Coordenador do curso de Contabilidade, março de 2012 apud VALASKI, 2012, p.44)

Observa-se assim, como apontou Valaski (2012), que há uma preocupação em adaptar o currículo aos três anos e que as necessidades locais vão ao encontro das concepções da Instituição, sacrificou-se então o estágio supervisionado (curso mecânica) para garantir que os alunos pudessem disputar o acesso aos cursos superiores no mesmo tempo dos alunos do ensino médio regular (não profissionalizante).

Ao deixar o estágio supervisionado como uma simples opção ao discente entre fazer ou não fazer, como se a falta da atividade não fosse ter impacto nenhum na sua formação, isso caracteriza que é um componente curricular sem importância ao discente, e pode alimentar a sua percepção de desvalorização do profissional de nível médio técnico em relação ao profissional de nível superior.

Atualmente, além dos métodos de pesquisas convencionais acadêmicas, as redes sociais, como o Facebook, são serviços que podemos nos utilizar para captar a percepção de determinado assunto, pois nessas redes há as relações sociais entre pessoas, que compartilham pensamentos, interesses e atividades em comum, e muitas vezes os usuários se expressam livremente. Existe nessas redes grupos de estudantes dos Institutos Federais. São vários posts que denotam o desinteresse pela parte profissionalizante, em um deles se vê a publicação "...sou obrigada a ter oito aulas exaustivas por dia" "Por um técnico que me vai ser inútil": 
Figura 2 Grupo de Estudantes dos Institutos Federais no Facebook

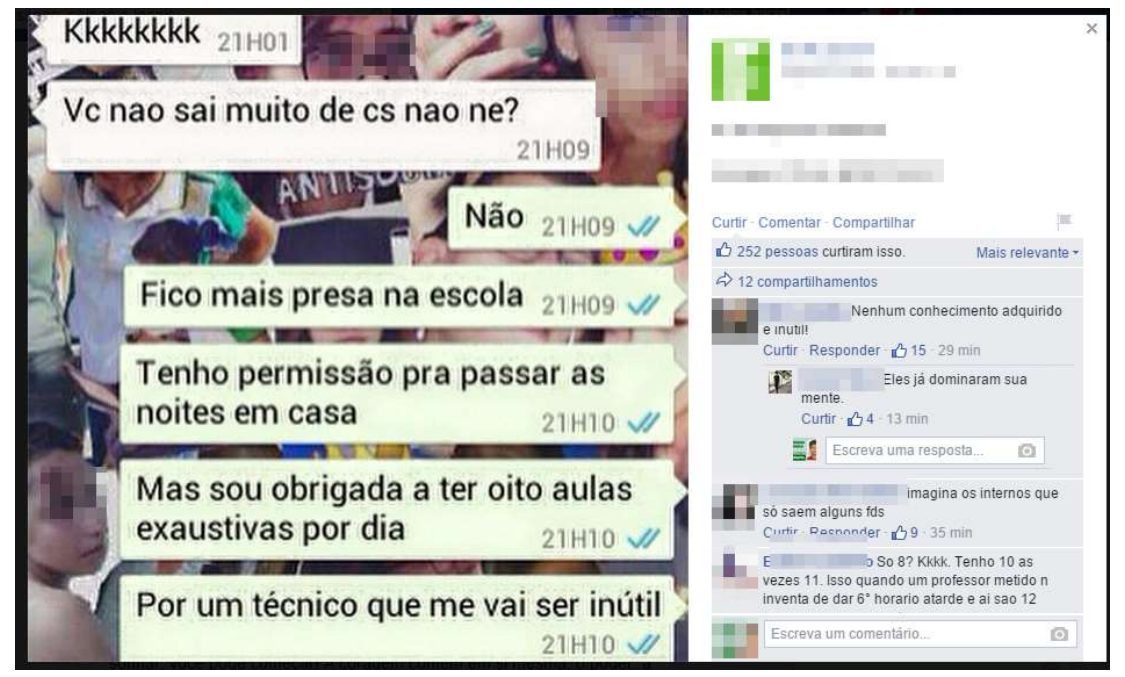

Fonte: Pesquisa Própria na Rede Social Facebook

O grupo é aberto a todos os usuários do facebook, possui mais de 88.000 "curtidas" (assinantes) muitos dos assinantes da página são alunos do ensino integrado, vê-se que muitos curtiram o "post" (se viu representado) e a até mesmo compartilhou o pensamento, sentimento.

Ao que parece essa predileção pelo propedêutico das Instituições Federais, e o seu consequente reforço, é geral, pois os alunos de escolas federais tiveram as maiores médias nas provas do Enem 2014 (Tabela 1), superando até mesmo estudantes de escolas particulares, portanto é evidente que o propedêutico se encontra fortalecido, mas o profissionalizante, ao que tudo indica, teve que ceder seu espaço para isso e o descaso com o estágio supervisionado serve-nos de indicador para essa situação. 
Tabela 1 Médias do ENEM 2014 por Dependência Administrativa

\section{Desempenho dos concluintes por rede de ensino}

\begin{tabular}{|c|c|c|c|c|c|c|}
\hline $\begin{array}{c}\text { Dependência } \\
\text { Administrativa }\end{array}$ & CH & CN & LC & MT & Redação & Média Prouni \\
\hline Federal & 610,2 & 557,5 & 563,2 & 589,6 & 618,7 & 588,8 \\
\hline Estadual & 528,2 & 466,6 & 494,7 & 451,5 & 434,7 & 477,7 \\
\hline Municipal & 542,7 & 479,4 & 506,7 & 472,4 & 458,2 & 494,8 \\
\hline Privada & 583,3 & 531,9 & 544,5 & 544,1 & 570,8 & 556,7 \\
\hline
\end{tabular}

Fonte: sítio do INEP3

O excelente desempenho das escolas técnicas federais para o acesso aos cursos superiores mais concorridos já acontecia com as escolas técnicas federais em fins da década de 80 . Segundo Castro (2005, p.3), uma pesquisa realizada naquela época apontou que entre dez escolas, as escolas técnicas federais de artes industriais eram a que "haviam colocado o maior número de aprovados nos cursos mais concorridos de São Paulo (por exemplo, medicina, direito e engenharia da Universidade de São Paulo)".

Em 2012 uma auditoria do TCU (Tribunal de Contas de União) já havia evidenciado o ótimo desempenho da rede federal que oferta educação profissional no Enem de 2009, também sendo superior aos resultados da rede privada, mas também descreveu preocupação do modo como vem sendo realizadas as ações de inserção profissional nessas instituições, inclusive com a situação do estágio supervisionado.

${ }^{3}$ Endereço completo nas referências bibliográficas 
Ao agregar as notas por cinco áreas de conhecimento, quando se comparam os resultados no Enem de alunos oriundos da Rede Federal de Educação Profissional com os que vieram de instituições de outras redes, verifica-se que o desempenho dos primeiros é nitidamente superior ao dos demais estudantes. (TCU-Relatório de Auditoria,2012, p.7)

Gráfico 1 Desempenho comparado no Enem de alunos de escolas técnicas de diferentes redes de educação profissional, por área de conhecimento, em 2010

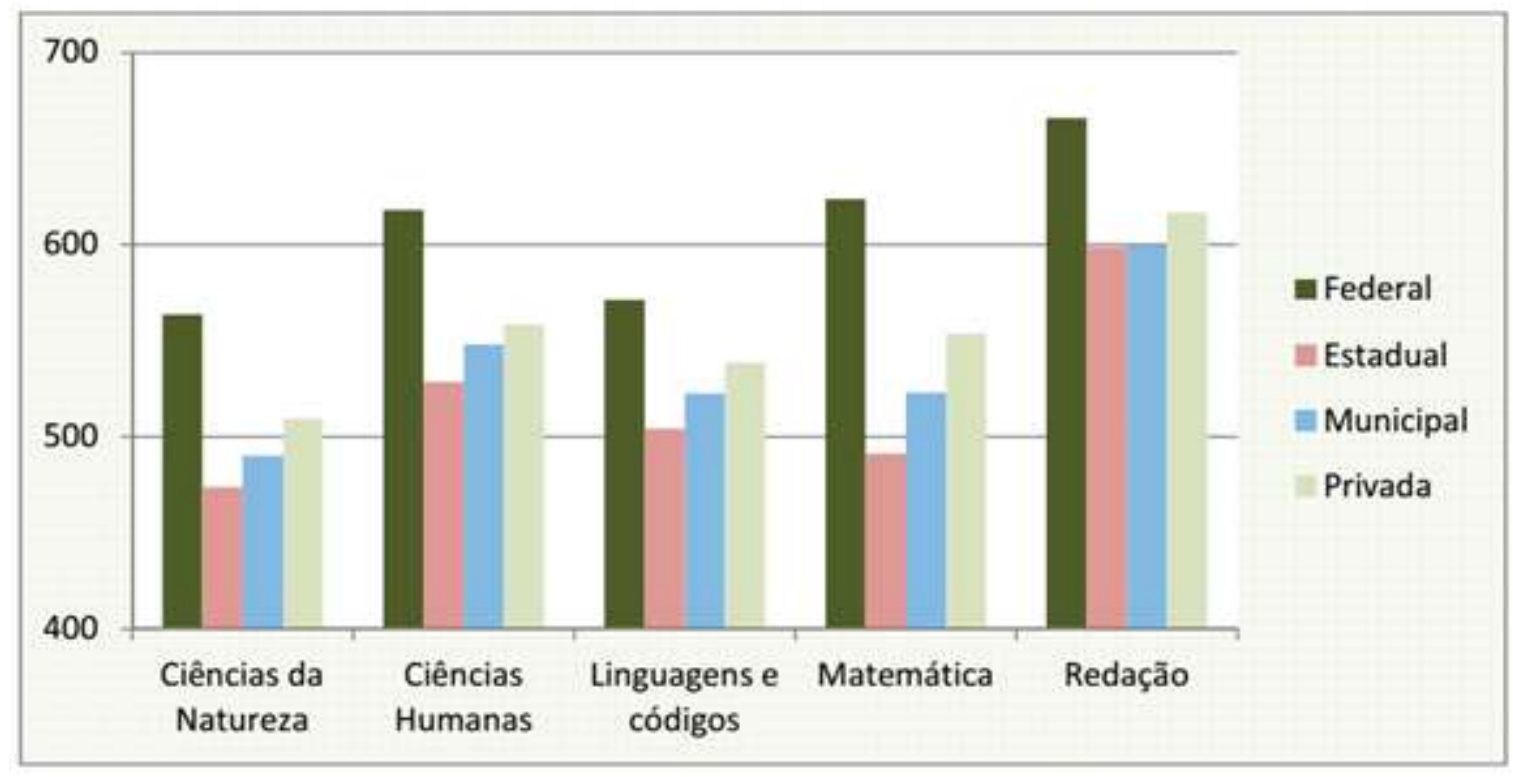

Fonte: TCU-Relatório de Auditoria(2012, p.7)

O relatório do TCU reconhece o bom desempenho dos alunos da educação profissional no ensino médio, mas mostra-se preocupado como estão sendo operacionalizados as ações de inserção profissional pelos Institutos Federais, dentre elas a promoção de estágios. Para o TCU esse tema (as ações de inserção profissional) "é de suma importância para a efetividade de uma política de educação profissional, que nunca pode perder de vista a empregabilidade de seus alunos". (TCU-Relatório de Auditoria,2012, p.5) 
204. As demandas profissionais requeridas pelo sistema produtivo, no atual contexto competitivo, exigem habilidades empreendedoras (VOLPATO e PAROLIN, 2008). Os mesmos autores destacam que o empreendedorismo representa fenômeno global com direta correlação com o crescimento econômico. Além disso, no Brasil, a via predominante para que os alunos de educação profissional possam para praticar e desenvolver seus conhecimentos dentro das empresas dá-se por meio de estágios. Desta forma, a política de estágios mostra-se como muito relevante não só na inserção profissional dos estudantes no mercado de trabalho como também em sua formação acadêmica. (TCU-Relatório de Auditoria,2012, p.37)

O mesmo relatório indicou baixa proporção de alunos dos Institutos Federais com acesso a estágio, e diante dos resultados da auditoria foram feitas recomendações, entre elas:

Ante o exposto, entende-se oportuno recomendar à Setec/MEC que, em conjunto com os Institutos Federais, institua plano voltado a ampliar as ações de inserção profissional de alunos da Rede Federal de Educação Profissional, Científica e Tecnológica que contemple: a) fomento à instalação de incubadoras de empresa, empresas juniores e cursos de empreendedorismo, com ênfase nos campi situados fora das capitais; b) incentivo a realização de estágios conscientizando os alunos da importância da empregabilidade; c) acompanhamento da empregabilidade dos alunos egressos; d) supervisão das políticas de incentivo ao empreendedorismo e de fomento a estágios que vierem a ser adotadas pelos Institutos.(TCU-Relatório de Auditoria,2012, p.42, grifo nosso)

A auditoria do TCU, portanto, evidencia que de fato existe um desbalanceamento dos eixos de formação da política pública do ensino integrado como vimos até esse momento, com o domínio do propedêutico sobre o profissionalizante, e ainda indica a falta de valorização que é dada ao estágio supervisionado nas Instituições Federais.

Favorecendo o ensino propedêutico em detrimento do ensino profissionalizante, visto à desvalorização do estágio supervisionado, a rede federal profissionalizante, que oferta um ensino propedêutico de qualidade, propícia um ambiente adequado para aqueles que buscam, na maioria das vezes, somente um 
ensino propedêutico de qualidade sem nenhuma necessidade da obtenção da habilitação técnica de nível médio.

O estágio supervisionado, embora seja um importantíssimo componente curricular do eixo profissionalizante, não se limita somente a esse eixo, e também não é somente a hora da prática. O Parecer N. ․: CNE/CEB 35/2003 faz excelente resumo do alcance do estágio supervisionado ao referenciar sua importância ainda na antiga lei do estágio, a LEI N 6.494, DE 7 de Dezembro de 1977.

Como vemos, o estágio supervisionado, já na legislação específica, representava muito mais que simples oportunidade de prática profissional, embora tenha nascido como eminentemente profissionalizante. Ele não pode ser considerado apenas como uma oportunidade de "treinamento em serviço", no sentido tradicional do termo, uma vez que representa, essencialmente, uma oportunidade de integração com o mundo do trabalho, no exercício da troca de experiências, na participação de trabalhos em equipe, no convívio sócio-profissional, no desenvolvimento de habilidades e atitudes, na constituição de novos conhecimentos, no desenvolvimento de valores inerentes à cultura do trabalho, bem como na responsabilidade $\mathrm{e}$ capacidade de tomar decisões profissionais, com crescentes graus de autonomia intelectual.(PARECER N..': CNE/CEB 35/2003, p.9)

Dada a importância do estágio supervisionado no ensino integrado, na subseção a seguir aprofundaremos na discussão desse importante componente curricular.

\subsection{Destacando a Importância do Estágio Supervisionado no Ensino Integrado}

Faria (2009) desenvolveu uma pesquisa no Instituto Federal de Educação, Ciência e Tecnologia de Minas Gerais - Campus de Bambuí tendo como objetivo principal identificar a contribuição do estágio curricular supervisionado para a formação profissional do Técnico Agrícola daquela instituição. Diante das respostas dos alunos, o pesquisador conclui que: 
O estágio curricular é o componente que mais contribui para inserir o profissional no âmbito da realidade regional. Os alunos têm conhecimento da importância do estágio, considerando-o como elemento fundamental no processo de formação curricular. (FARIA, 2009, p.48)

Não há dúvidas que a experiência do estágio supervisionado possa melhor preparar o discente para o mercado de trabalho e que na sua falta esse aspecto ficaria prejudicado. Sendo assim, o estágio supervisionado é elemento fundamental para enriquecer o caráter profissionalizante nas instituições de ensino (principalmente as profissionalizantes), e, que por consequência, também melhor desenvolver a identidade profissional do aluno. Segundo Lima e Vasconcelos (2006, p.28) "o Estágio contribui diretamente para a construção da identidade profissional dos graduandos que, submetidos ao campo real de trabalho, internalizam suas vivências e as ressignificam", e com o ensino médio profissionalizante não há de ser diferente.

De acordo com o portal da indústria ${ }^{4}$, o SENAI (Serviço Nacional de Aprendizagem Industrial) é um dos cinco maiores complexos de educação profissional do mundo e o maior da América Latina, informa também que os cursos do SENAI "formam profissionais para 28 áreas da indústria brasileira, desde a iniciação profissional até a graduação e pós-graduação tecnológica". No regulamento do estágio supervisionado das unidades dessa instituição o estágio supervisionado é declarado como:

O estágio supervisionado é uma das mais eficientes formas de propiciar ao estudante a complementação profissional, pois o coloca em contato direto com a realidade da indústria, com o ambiente real de trabalho e com os mais diversos problemas técnicos. Neste período, também o aspecto humano-social é aprimorado, em face do conseqüente contato com problemas sociais e culturais, que se apresentam no ambiente de trabalho. (SENAI-SP, 2012 p.4)

Buriolla (2001), descreve sucintamente e claramente sobre o estágio supervisionado no serviço social, mas que se aplica também a qualquer habilitação profissional: 
O estágio é concebido como um campo de treinamento, um espaço de aprendizagem do fazer concreto do serviço social, onde um leque de situações, de atividades de aprendizagem profissional que se manifestam para o estagiário, tendo em vista sua formação. $O$ estágio é o lócus onde a identidade profissional do aluno é gerada, construída e referida; volta-se para o desenvolvimento de uma ação vivenciada, reflexiva e crítica, e por isso, deve ser planejado gradativa e sistematicamente. (BURIOLLA, 2001, p.13)

Como vimos o estágio supervisionado vai além de preparar o discente para o mercado de trabalho, o estágio supervisionado é ato educativo. Encontra-se o estágio definido como ato educativo desde o Parecer N. : CNE/CEB 35/2003 (Normas para a Organização e Realização de Estágio de Alunos do Ensino Médio e da Educação Profissional):

\footnotetext{
O estágio, juntamente com o estatuto da aprendizagem, deve ser entendido como uma excelente alternativa para a inserção de jovens no mundo do trabalho, sustentando uma política de educação profissional ou de preparação básica para o trabalho, na perspectiva do desenvolvimento de competências profissionais, caracterizado pela capacidade de enfrentar desafios imprevistos, não planejados e imprevisíveis, expresso pela capacidade de julgamento, decisão e intervenção diante do novo $e$ do inusitado. $O$ estágio é, essencialmente, um Ato Educativo. (PARECER N. ${ }^{\circ}$ : CNE/CEB 35/2003, p.11)
}

Essa concepção de estágio como ato educativo ainda é contemplada através da LEI No 11.788, DE 25 DE SETEMBRO DE 2008 que dispõe sobre o estágio de estudantes: 
Art. 10 Estágio é ato educativo escolar supervisionado, desenvolvido no ambiente de trabalho, que visa à preparação para o trabalho produtivo de educandos que estejam freqüentando o ensino regular em instituições de educação superior, de educação profissional, de ensino médio, da educação especial e dos anos finais do ensino fundamental, na modalidade profissional da educação de jovens e adultos.

Para Macário (2001, p.10-11) o ato educativo na sua gênese ontológica é o momento do próprio trabalho, ou seja, "o próprio ato de objetivação posto pelo trabalho é educativo".

Saviani (2012), explicitando sobre a pedagogia fenomenológica, descreve sobre o ato educativo:

[...] o ato educativo é entendido como possibilitando a abertura das consciências para o mundo, empenhando-se os alunos em compreender o sentido dos fenômenos constitutivos do mundo vivido, exercitando, para isso, sua capacidade de operar reduções. Aprenderão, diante de determinado problema, a colocar entre parêntesis as opiniões corretas, as crenças, os preconceitos e, até mesmo, as teorias já formuladas começando pela análise direta dos fenômenos implicados no enunciado do problema que se quer esclarecer. (SAVIANI, 2012, p. 185)

Na mesma linha de reflexão, em ZABALZA(1998) temos que:

$\mathrm{O}$ ato educativo é um ato complexo com o qual se deseja que o aluno (a) simultaneamente aprenda a pensar, desenvolva um pensamento autónomo e tenha acesso aos conteúdos do mundo cultural ao qual pertence, faça uma aprendizagem de experiência humana culturalmente organizada. Que esta apropriação seja feita de forma crítica é naturalmente o desejo de uma posição moderna na educação. (ZABALZA, 1998, p. 167)

A importância dessa atividade, o estágio supervisionado, é pesquisada e retratada pelo Conselho Pleno/Conselho Nacional de Educação (CNE), em parceria entabulada em Acordo de Cooperação Técnica entre o Governo Brasileiro e a UNESCO, com vistas a compreender como estaria sendo desenvolvida a atividade de Estágio Supervisionado, contemplando instituições de todas as modalidades de 
educação e ensino, em cursos de Educação Básica e Superior. A pesquisa é extensa, e foi dividida em três produtos (documentos técnicos).

Os documentos apontam diversas deficiências de como o estágio supervisionado é desenvolvido nas instituições, observou-se, por exemplo, que o ato educativo proporcionado pelo estágio supervisionado foi reduzido a ato burocrático: "há um outro número significativo de instituições que simplesmente transformaram a possibilidade do ATO EDUCATIVO no ATO BUROCRÁTICO". (CNE/UNESCO Produto 3, s.d., p.114)

O estudo, diante das deficiências observadas no estágio supervisionado obrigatório, mostrou preocupação quanto à modalidade de estágio não obrigatório:

Do estudo realizado também foi possível identificar, que nem todas as instituições possibilitam compartilhamento de saberes, oriundos das experiências de estágio supervisionado obrigatório, o que implica imediatamente a pensar, acerca do estágio não obrigatório, o que instala uma importante preocupação, pois em sendo um ATO EDUCATIVO o Estágio Supervisionado, não está sendo atendido em seu objetivo nuclear, conforme destacado na Lei 11.788, em seu Art. $1^{\circ}$, parágrafo $2^{\circ}$ :

$\S 2^{\circ} \mathrm{O}$ estágio visa ao aprendizado de competências próprias da atividade profissional e à contextualização curricular, objetivando o desenvolvimento do educando para a vida cidadã e para o trabalho. (CNE/UNESO Produto 3, s.d., p.106)

A preocupação relatada na pesquisa CNE/UNESCO (s.d.) é válida, pois como observado por Valaski (2012) quando o estágio é de categoria não obrigatório (e opcional) os alunos não o fazem, é natural, e até mesmo óbvio, uma vez que foi visto que nas Instituições tratadas neste estudo o interesse do aluno é a preparação para disputar o acesso nos cursos de graduação e não o mercado de trabalho de sua formação técnica. 
O Documento circulado pelo MEC intitulado "Institutos Federais De Educação, Ciência E Tecnologia Um Novo Modelo Em Educação Profissional e Tecnológica. Concepção e Diretrizes", ressalta:

Nesse ponto, entende-se que a educação precisa ser tomada numa dimensão muito maior. "Ela deve incorporar todas as dimensões educativas que ocorrem no âmbito das relações sociais que objetivam a formação humana nas dimensões social, política e produtiva" (Paraná, 2006). Isto representa tomar o trabalho como princípio educativo e como categoria orientadora das políticas da educação profissional e tecnológica. Os Institutos Federais de Educação, Ciência e Tecnologia, sem ignorar o cenário da produção, tendo o trabalho como seu elemento constituinte, propõem uma educação em que o domínio intelectual da tecnologia, a partir da cultura, firma-se. Isto significa dizer que as propostas de formação estariam contemplando os fundamentos, princípios científicos e linguagens das diversas tecnologias que caracterizam o processo de trabalho contemporâneo, considerados em sua historicidade. (MEC,2010, p.33)

Assim, o atual cenário do ensino médio integrado conflita-se com a concepção e diretrizes dos Institutos Federais, pois como vimos é evidente o reforço do propedêutico em detrimento do "trabalho como princípio educativo", do "cenário de produção" e em detrimento também do "trabalho como seu elemento constituinte", neste ponto vale lembrar a observação de Kuenzer (2001):

Mais do que nunca o Ensino Médio no início do novo século deverá superar a concepção conteudista que o tem caracterizado, em face de sua versão predominantemente propedêutica, para promover mediações significativas entre os jovens e os conhecimentos científicos, articulando saberes tácitos, experiências e atitudes. (KUENZER, 2001, p.42)

E também vale lembrar a reflexão de Carvalho (2003, p.17) quando explicita os diferentes sentidos que a qualificação assume para os diferentes atores sociais pontuando que "não se pode falar em qualificação, sem a integração entre potencial do indivíduo e qualificação do posto, pois não pode haver ruptura entre formação e trabalho, entre a aprendizagem e a prática do trabalho". 
Portanto, constata-se uma evidente perda do caráter profissionalizante na política pública do ensino integrado, assim, como fica evidenciado também, que o estágio supervisionado, que deveria ser um elemento curricular que poderia promover o alcance da política pública no eixo profissionalizante está sendo drasticamente atingido nessa descaracterização.

As análises empreendidas neste capítulo nos permitem constatar de um lado, a necessidade de assumir o trabalho como princípio educativo e categoria orientadora das políticas da educação profissional e tecnológica como requer o MEC das instituições profissionalizantes, assim como, a necessidade de assumir o estágio supervisionado como ato educativo como obriga a Lei 11.788/08. De outro lado, afirma a necessidade de se romper a concepção conteudista do ensino médio e a restauração do elo entre aprendizagem e prática do trabalho como afirmam Kuenzer (2001) e Carvalho (2003) respectivamente, superar as deficiências e as falhas de operacionalização do estágio supervisionado como apontado pela pesquisa CNE/UNESCO e pelo relatório do TCU, que inclusive recomendou a SETEC para que em conjunto com os Institutos Federais instituísse plano voltado a ampliar as ações de inserção profissional que contemplasse o estágio supervisionado.

Diante do exposto acima, entendemos como muito importante que as instituições que ofertam o ensino integrado investiguem a motivação e as expectativas dos seus discentes e também como vem sendo operacionalizado o estágio supervisionado. Os resultados poderão indicar a reprodução ou superação das mazelas acima mencionadas, e poderão contribuir para o ajuste na política pública. Tal é o mote do nosso estudo e será objeto do próximo capítulo. 


\section{CAPÍTULO 2}

\section{O CARÁTER PROFISSIONALIZANTE NOS CURSOS TÉCNICOS INTEGRADOS DO IFNMG-JANUÁRIA}

No primeiro capítulo discutiu-se a perda do caráter profissionalizante da formação integrada e de que esta se deve, sobretudo, às expectativas e motivações discentes, por um lado, e a ausência do estágio supervisionado como elo integrador dos dois polos da formação, por outro.

Objetivando verificar como este fenômeno ocorre concretamente realizamos uma pesquisa nos cursos Integrados do Instituto Federal do Norte de Minas Gerais Campus Januária (IFNMG - Januária) a fim de conhecer o indicativo do caráter profissionalizante da política pública através do perfil dos discentes (motivação e expectativas) em cursos que possuem o estágio supervisionado obrigatório e não obrigatório (opcional), a hipótese é que o fenômeno também esteja ocorrendo no IFNMG-Januária.

Este estudo se mostra importante no IFNMG-Januária, porque não existe estudo aprofundado na Instituição que desvele os motivos que levaram os discentes a ingressarem na modalidade integrada e os resultados na formação profissional com as diferentes implementações do estágio supervisionado adotadas pela Instituição.

\subsection{Lócus da pesquisa: IFNMG - Campus Januária}

O IFNMG - Januária originou ${ }^{5}$-se como Escola Agrotécnica em 18 de dezembro de 1960, no final do governo de Juscelino Kubitschek ano do centenário da cidade, criou-se de um terreno de 104 ha, área da fazenda denominada São Geraldo, onde há 12 anos funcionava o Posto Agro-Pecuário (sic) do próprio Ministério da Agricultura através de um convênio celebrado entre o Governo Federal e o Estadual.

${ }^{5}$ Histórico do Campus Januária extraído do site da Instituição: http://www.ifnmg.edu.br/maisnoticias?id=499 
Naquela época, a Escola Agrotécnica de Januária, tinha o propósito de permitir ao egresso da Escola Caio Martins a complementação dos seus estudos, ou seja, os alunos fariam as primeiras séries naquela escola e depois dariam continuidade no ensino na Escola Agrícola que era subordinada ao Ministério da Agricultura e estruturada nos moldes do Decreto $n^{\circ} 21.667$, de 20/08/46 e pelo Decreto-Lei $n^{\circ} 9.614$ de 20/08/1946, até o advento da Lei $n^{\circ} 4.024$, de 20 de dezembro de 1961, Lei de Diretrizes e Bases da Educação Nacional.

Com pouca infraestrutura quando da sua criação o ensino, caracterizou-se pela informalidade, os alunos não recebiam históricos nem certificados, até o ano de 1964, quando, efetivamente, começa a ministrar o Curso Ginasial Agrícola, com a matrícula da primeira turma em regime de internato, servindo a alunos provenientes da comunidade januarense, de toda a região do vale do São Francisco e de outros Estados. Neste mesmo ano, pelo Decreto Presidencial, no 53.558, de 13/02/164, a Escola Agrotécnica de Januária passou-se a denominar Colégio Agrícola, cuja denominação ainda se faz presente até os dias de hoje para muitos januarenses.

Em 1967 o Colégio Agrícola de Januária, até então subordinado ao Ministério da Agricultura, foi transferido para o Ministério da Educação e Cultura pelo Decreto $n^{\circ}$ 60.731, nesse mesmo ano, em 16 de novembro, formou-se a primeira turma de Ginasianos Agrícolas, habilitados como Mestres Agrícolas, e ainda ocorreu às inscrições e matrículas para a primeira série do Curso Técnico Agrícola, ramo Agricultura, em nível de $2^{\circ}$ Grau.

Em decorrência da implantação da Lei 5.692/71, no ano letivo de 1974, a Escola fez uma grande mudança no seu Currículo e Calendário escolar, abandonando progressivamente o calendário agrícola regional, passando a ministrar, sem prejuízo para os alunos que cursavam a habilitação até então oferecida, o Curso Técnico Agrícola - Habilitação em Agropecuária

O Colégio Agrícola conseguiu autonomia didático-pedagógica e administrativa em 1993, pela Lei $n^{\circ} 8.731$, do dia 16 de novembro de 1993, através de sua autarquização; ponto muito positivo para o desenvolvimento administrativo, político e pedagógico da Instituição, favorecendo significativamente sua gestão.

No ano letivo de 1996, além da tradicional habilitação em agropecuária a Instituição passou a oferecer uma nova habilitação, a de Processamento de Dados, 
em nível de pós-segundo grau, a qual posteriormente passou a denominar-se Técnico em Informática; em 1998, foi implantada a Habilitação de Técnico em Agroindústria e no ano letivo de 2000, foi implantado a Habilitação de Técnico em Enfermagem.

Em 2001, mais duas habilitações foram implantadas: uma na Área de Gestão Técnico em Administração e outra na Área de Meio Ambiente - Técnico em Meio Ambiente. É importante ressaltar que neste ano a Instituição, realizou a separação de matrículas do seu curso Técnico em Agropecuária, que até então, era constituído de disciplinas de Ensino Médio e de disciplinas de Educação Profissional. A Instituição passa a oferecer os cursos de Ensino Médio e de Técnico em Agropecuária, separadamente obedecendo aos princípios pedagógicos e filosóficos dos Referencias Curriculares.

Pelo Decreto Presidencial s/n, de 13 de novembro de 2002, a Instituição passa a ser denominada como Centro Federal de Educação Tecnológica de Januária, CEFET-Januária, passando a ofertar nesse mesmo ano com a autorização da Portaria no 3.634 de 19/12/2002, o funcionamento do primeiro Curso Superior na Instituição: o Curso Superior de Tecnologia em Irrigação e Drenagem.

Em 2004, pelo Decreto, nº 5.154 de 23 de julho de 2004, O CEFET-Januária manteve a educação profissional técnica de nível médio concomitante de forma articulada ao ensino médio com duração de 03 (três) anos.

Em 2006 o CEFET Januária passa a oferecer os Cursos Superiores de Tecnologia em Sistemas de Informação (posteriormente denominado como Tecnologia em Análise e Desenvolvimento de Sistemas) e em Tecnologia em Gestão Comercial. Ainda em 2006, foram autorizados os cursos de Bacharelado em Administração de Empresas (extinguindo o anterior: Gestão Comercial); Licenciatura em Matemática, em como a iniciação dos cursos do Programa de Educação de Jovens e Adultos, PROEJA Indígena, com formação em Agropecuária e PROEJA com formação em Informática.

No ano de 2007 foi implementado a integração do Ensino Médio ao Técnico em Informática e Agropecuária, conforme prevê o decreto n 5154 de 23/07/2004, além da criação do Curso Superior de Bacharelado em Agronomia. 
Com Plano de Expansão da Rede Federal de Educação Profissional e Tecnológica, o CEFET Januária foi contemplado para a implantação e administração de três Unidades de Ensino Descentralizadas - UNEDs, nas cidades de Arinos, Almenara e Pirapora.

Em 31 de março de 2008, foi aprovada na íntegra, conforme Portaria № 116 da SETEC/MEC, a proposta de constituição do Instituto Federal de Ciência e Tecnologia do Norte de Minas, mediante a integração do CEFET Januária, com a EAF de Salinas.

Atualmente o IFNMG - Januária oferece (além de outros cursos) três cursos profissionalizantes integrados ao ensino médio: Agropecuária, Informática e Meio Ambiente.

Em 2008, a Instituição em fase de mudança de CEFET para Instituto Federal, foi autorizada a implantar o curso de Licenciatura em Física. Ainda neste ano, pela Lei 11.892, de 29/12/2008, foram criados em todo o país, 38 Institutos Federais de Educação Ciência e Tecnologia, entre os quais o Instituto Federal do Norte de Minas Gerais, compondo-se de Sete Campi (Campus Almenara, Campus Araçuaí, Campus Arinos, Campus Januária, Campus Montes Claros, Campus Pirapora e Campus Salinas).

Em 2010, ano em que Instituição comemora o seu Jubileu de Ouro, o Campus Januária é contemplado com o Curso de Engenharia Agrícola e Ambiental.

Todas essas transições e implementações ocorreram em pouco mais de 50 anos de história, e embora seja um tempo considerável, que teoricamente dá à instituição certa experiência em ofertar os cursos integrados, vê-se a necessidade de um estudo que verifique se o IFNMG-Januária está de fato conduzindo a política pública de maneira que ela satisfaça os dois principais eixos: prosseguimento de estudos e formação profissional. Esse último em especial, pois é o que difere os Institutos Federais das outras instituições que não possuem a obrigatoriedade da formação profissional.

Atualmente o IFNMG - Januária oferece (além de outros cursos) três cursos profissionalizantes integrados ao ensino médio: Agropecuária, Informática e Meio Ambiente. 
Existem diferentes implementações do estágio supervisionado nos cursos de ensino integrado do IFNMG-Januária, no curso de Informática é não obrigatório (opcional), entretanto, no curso integrado Agropecuária, o estágio é obrigatório com carga horária de 160 horas para o projeto que finda em 2015, e para quem iniciou em 2014 são 150 horas. O mesmo ocorre com o recém-criado curso Integrado de Meio Ambiente para o qual o estágio é obrigatório com 80 horas.

Os documentos que contém as diretrizes que orientam o estágio supervisionado na Instituição serão tratados a seguir.

\subsubsection{Contextualização do Estágio Supervisionado no IFNMG}

Para compreendermos melhor o contexto no qual se insere o nosso objeto de pesquisa, fizemos uma análise dos documentos que o regulam.

O documento "Regulamento dos Cursos de Educação Profissional Técnica De Nível Médio Do Instituto Federal do Norte de Minas Gerais (IFNMG) ", entre outras diretrizes, faz menção ao estágio supervisionado no seu art. 21.

No seu Art. $1^{\circ}$, é descrito o propósito do documento:

Art. $1^{\circ}$ Este regulamento apresenta as diretrizes, normas e procedimentos a serem adotados nos Cursos Técnicos de Nível Médio e tem por finalidade padronizar e dinamizar o fluxo das ações administrativas e didático-pedagógicas a serem desenvolvidas no âmbito do Instituto Federal do Norte de Minas Gerais - IFNMG. (IFNMG, 2013, p.2)

No Capítulo III, seção I, estão descritas as diretrizes para o desenvolvimento do currículo, destacamos algumas relevantes a discussão: 
Art. 15. O currículo desenvolvido pela instituição deve observar os seguintes princípios:

I - integração de diferentes formas de educação para o trabalho, para a ciência e para a tecnologia, devendo conduzir ao permanente desenvolvimento de aptidões para a vida produtiva e social;

II - atualização, mediante informações sobre o mundo do trabalho, principalmente nas áreas de influência do Campus, de forma a possibilitar o aprimoramento do sistema de oferta de cursos;

[...]

Art. 17. A organização curricular dos cursos deverá propiciar a articulação entre os conteúdos de formação geral e profissional, de modo a contribuir para a formação integral do educando como cidadão consciente, atuante e criativo e como profissional responsável e competente para desempenhar de forma plena seu papel social, político e econômico na sociedade, considerando os conhecimentos prévios dos discentes a serem ampliados durante o curso.

$[\ldots]$

Art. 19. Os currículos serão periodicamente avaliados, podendo sofrer adaptações ou alterações que, respeitadas a legislação vigente e a regulamentação interna, promovam a sua permanente atualização e melhor adequação às finalidades e desenvolvimento dos cursos.

[..]

Art. 21. O estágio curricular supervisionado, que se constitui em aprimoramento das experiências escolares para as vivências profissionais e as relações socioculturais, deverá ser realizado conforme as exigências do Plano de Curso e a legislação pertinente, objetivando a integração do discente com o mundo do trabalho. (IFNMG, 2013, p.4-5)

Podemos perceber que as diretrizes acima transcritas para elaboração do currículo se relacionam fortemente com o mundo do trabalho, e como já discutido no primeiro capítulo, o estágio supervisionado, através do ato educativo e de sua natureza de integrar os diferentes atores (Instituição de ensino, Discentes e Concedentes) se mostra um importante componente curricular para satisfazer tais diretrizes.

Quanto à avaliação e atualização do currículo, presente nas diretrizes de elaboração do currículo do IFNMG, o estágio supervisionado pode ser um excelente instrumento para a instituição analisar criticamente o próprio currículo, principalmente através do feedback dos estagiários, que, por exemplo, poderão indicar a instituição 
se houve a necessidade de aprendizado de outros conhecimentos teóricos ou práticos durante o estágio e que não foram abordados no curso.

Apesar da importância de o estágio ser retratada no documento, no art. 21, para desenvolver no discente o "aprimoramento das experiências escolares para as vivências profissionais e as relações socioculturais", o Capitulo III, que trata especificamente do estágio supervisionado, permite a possibilidade de não o exigir:

Art. 114. Estágio é o ato educativo escolar supervisionado que visa à preparação do discente para o trabalho na área de sua formação profissional.

$\S 1^{\circ}$. O Estágio faz parte do Plano de Curso, além de integrar o itinerário formativo do educando.

$\S 2^{\circ}$. O Estágio Curricular Supervisionado, para o curso que o exija, é atividade obrigatória para obtenção do grau de ensino e constará no currículo do curso.

$\S 3^{\circ}$. O estágio visa ao aprendizado de competências próprias da atividade profissional e à contextualização curricular, objetivando o desenvolvimento do educando para a vida cidadã e para o trabalho. (IFNMG, 2013, p.28)

No Art. 115 é informado o documento que trata especificamente do estágio supervisionado.

Art. 115. Observadas as disposições da legislação em vigor e as determinações dos conselhos profissionais dos cursos, demais normas referentes ao Estágio Curricular Supervisionado são estabelecidas em Regulamento próprio - Regulamento para Estágios de Discentes do Instituto Federal de Educação, Ciência e Tecnologia do Norte de Minas Gerais - IFNMG. (IFNMG, 2013, p.28)

O "Regulamento Para Estágios De Discentes Do Instituto Federal De Educação, Ciência E Tecnologia Do Norte De Minas Gerais" engloba as diretrizes para todos os níveis de ensino (Médio e Superior) no âmbito do IFNMG, em seu Capítulo I descreve que: 
Art. $1^{\circ}$. O estágio Curricular Supervisionado do IFNMG encontra amparo legal na Lei $\mathrm{N}^{\circ} 11.788$ de 25 de setembro de 2008, na Resolução CNE/CEB n ${ }^{\circ}$ 1, de 21 de janeiro de 2004; na Resolução CNE/CP $\mathrm{n}^{\circ}$ 2, de 19 de fevereiro de 2002 e nas demais regulamentações e orientações emanadas pelos órgãos superiores competentes. (IFNMG, 2012, p.1)

No Capítulo II é descrito os objetivos e finalidades:

Art. $2^{\circ}$. O estágio visa ao aprendizado de competências próprias da atividade profissional e a contextualização curricular, objetivando o desenvolvimento do educando para a vida cidadã e para o mundo do trabalho.

$\S 1^{\circ}$ - O estágio tem como objetivo proporcionar o exercício da competência técnica e o compromisso profissional com a realidade do país visando a complementar o ensino e a aprendizagem. Constituirse-á em um instrumento de integração teórico/prático, aperfeiçoamento técnico cultural, científico e de relacionamento humano.

$\S 2^{\circ}$ - Facilitar a adaptação social e psicológica do discente à sua futura atividade profissional, cabendo ao IFNMG zelar para que o estágio represente autêntica atividade pedagógica integrada.

$\S 3^{\circ}$ - Promover a articulação do IFNMG com o mundo do trabalho. (IFNMG, 2012, p.1)

Apesar de novamente, nos objetivos, a importância do estágio supervisionado ser relatada tanto para o discente quanto para a Instituição, o documento em seu Capítulo III, Art. $3^{\circ}$, §2 informa que o "Estágio não obrigatório é aquele desenvolvido como atividade opcional, acrescida à carga horária regular e obrigatória. ”, e, portanto, sendo de livre escolha do discente, nos cursos que essa categoria estiver implementada.

O estágio supervisionado de categoria "não obrigatório" opcional é implementado pelo IFNMG-Campus Januária no curso Técnico Integrado em Informática, caso o discente não o faça poderá concluir o curso normalmente e, teoricamente, sairá habilitado tanto para prosseguir os estudos em nível superior quanto habilitado para o mercado de trabalho, mesmo sem ter passado pela experiência do mercado de trabalho promovida pelo estágio supervisionado. 
No documento "Projeto De Curso Técnico Em Informática Integrado Ao Ensino Médio" de informática é explicada essa opcionalidade:

Como princípio educativo, o estágio significa atividade didática e social. Objetiva a contextualização, ressignificação social do trabalho e a inserção do aprendiz no ambiente real de atuação.

O Estágio não será obrigatório para o Curso Técnico em Informática Integrado ao Ensino Médio. Porém, se o aluno possuir interesse em realizá-lo, o estágio deverá ter um total de 160 horas. É facultado ao aluno dividir as horas destinadas as (sic) cumprimento do estágio em etapas, que não ultrapassem $80 \mathrm{~h}$ cada, a partir da conclusão do $1^{\circ}$ Módulo; ou poderá cumprir as $160 \mathrm{~h}$ após conclusão do curso. Para efeito de habilitação o estágio poderá ser cumprido, respeitando o currículo do curso, na área de interesse do aluno. No entanto, somente, poderá ser realizado em colaboração com empresas, instituições e outras, devidamente cadastradas na Escola. Para formalizar sua ocorrência o estágio deverá ser acompanhado de formulários específicos, facilitando o relatório da empresa e do estagiário. Tais documentos (relatórios e formulários) serão enviados à Coordenação Geral de Extensão e Integração Instituto-Empresa (CGEI) que, após análise, emitirá parecer aprovando ou não o estágio, devendo o fato ser comunicado ao estagiário e a Secretaria Escolar. (IFNMG-Januária, 2012, p.42)

Como se percebe, embora todos os documentos do IFNMG ressaltem a importância do estágio supervisionado, e até mesmo sendo essa importância descrita pelos estudiosos do tema e documentos legais, todos os benefícios advindos do estágio supervisionado podem ser dispensados no curso integrado informática segundo a vontade do aluno, é interessante notar o fato do curso de informática na modalidade subsequente da mesma instituição ser de categoria obrigatória.

No nosso ponto de vista, o fato do discente poder ignorar o estágio supervisionado, ou até mesmo caso opte em fazê-lo após a conclusão do curso, configura-se o estágio supervisionado como "atividade extracurricular", "apêndice da atividade escolar" contrariando o PARECER N. ${ }^{\circ}$ : CNE/CEB 35/2003 e também as recomendações da RESOLUÇÃO CNE/CEB N ${ }^{\circ}$ 1, DE 21 DE JANEIRO DE 2004 quando descreveu no seu $\S 3^{\circ}$ que "O estágio deve ser realizado ao longo do curso, permeando o desenvolvimento dos diversos componentes curriculares e não deve ser etapa desvinculada do currículo".(grifo nosso) 
Em quaisquer das modalidades de ensino em que haja a previsão de realização de Estágio Supervisionado, a primeira regra básica a ser seguida é a de que se trata de "estágio curricular". O estágio supervisionado é, essencialmente, uma atividade curricular. Isto significa que o Estágio Supervisionado não é uma "atividade extracurricular", não é um apêndice da atividade escolar. [...] (PARECER N. ${ }^{\circ}$ : CNE/CEB 35/2003)

O CNE/UNESCO (s.d., Produto 2, p.29) após pesquisa aprofundada no tema, também salienta que "Há uma precarização do Estágio Supervisionado, quando o mesmo é inserido no final do curso, perde-se o sentido do estágio enquanto função suplementar e de cunho educacional".

Mesmo estando na mesma Instituição de ensino, e ainda se tratando da modalidade de ensino técnico integrado, no projeto do curso de agropecuária o discente obrigatoriamente tem que realizar o estágio supervisionado para concluir o curso integrado:

O diploma de Técnico em Agropecuária cujo histórico engloba, no currículo, as disciplinas da Base Nacional Comum e Formação Profissional será de direito somente após conclusão seqüencial ou ordenada das séries que compõem o curso, incluindo o cumprimento integral da carga horária destinada ao Estágio Curricular Supervisionado. (IFNMG-Januária, 2012, p.12)

Na seção intitulada "Observações obrigatórias", entre outros apontamentos, é descrito novamente sua obrigatoriedade:

c) O Estágio Profissional Supervisionado é obrigatório de acordo com a Matriz Curricular, devendo ser viabilizado a partir da $2^{\mathrm{a}}$ série do curso. Na modalidade prevista para cursos técnicos de nível médio será realizado nos moldes do Art. 82 da lei 9.394 de 20.12.96, prevista e incluída do Regulamento para Estágios próprio da Instituição e aprovado pelo Conselho Superior. Além dos parâmetros previstos na Lei $n^{\circ} 9394$ LDB expostos neste plano de curso em espaço próprio. (IFNMG-Januária,2012, p.24)

Uma vez que, de acordo com o projeto de curso, o estágio é viabilizado a partir da $2^{\mathrm{a}}$ série onde ocorrerá a primeira etapa de 80 horas e a segunda etapa na $3^{\mathrm{a}}$ série 
com mais 80 horas $^{6}$, observa-se que o discente estagiará nos períodos de recesso escolar, provavelmente nas férias, já que ele cursa disciplinas pela manhã e tarde, sendo assim limita-se a experiência do estagiário, pois nesse período ocorrem as férias dos professores orientadores e também podem ocorrer as férias de vários profissionais das concedentes, inclusive as férias do supervisor do estágio da concedente.

O projeto caracteriza o estágio supervisionado como fundamental para o curso de agropecuária, entendemos que para o curso de informática não haveria de ser diferente, uma vez que todos os benefícios advindos do estágio supervisionado citados pela própria Instituição de igual modo também o enriqueceria a formação integral do educando de Informática.

O estágio curricular é um instrumento fundamental para fazer com que o técnico em Agropecuária ponha em prática os conhecimentos adquiridos, com vistas ao seu treinamento, facilitação da sua futura absorção no mercado de trabalho; adaptação social e psicológica a sua futura atividade profissional; à orientação do aluno na escolha de sua especialização profissional e ao desenvolvimento de competências para a vida cidadã e para o trabalho produtivo. (IFNMG-Januária,2012, p.25)

Para o curso de Meio ambiente, o plano de curso prevê 80 horas de estágio supervisionado, e também é enfatizada a sua importância:

O Estágio Curricular, compreendido como atividade afinada com o perfil profissional definido pelo curso, constitui-se em etapa fundamental na formação do aluno e em etapa obrigatória para a obtenção do diploma. Apresenta por objetivo fundamental a aplicação das disciplinas e habilidades adquiridas pelo aluno em sua formação técnica e deverá seguir o Regulamento de Estágio do IFNMG. (IFNMG-Januária,2014, p.54)

6 Segundo a Direção de Ensino do Campus Januária, os discentes de agropecuária que ingressaram na Instituição em 2014 terão que realizar 150 e não mais 160 horas de estágio supervisionado. 
Como visto, no curso integrado de Informática o estágio é opcional na modalidade integrada e obrigatório na modalidade subsequente, e caso o discente opte em realiza-lo terá carga horária de 160 horas; no curso integrado agropecuária o estágio supervisionado é obrigatório com carga horária de 160 horas para o projeto que finda em 2015, e para quem iniciou em 2014 são 150 horas; já no curso integrado de meio ambiente é obrigatório com carga de 80 horas.

Teoricamente, nos documentos do IFNMG que orientam sobre o estágio supervisionado, o componente curricular assume grande importância na formação discente, mas em contrapartida observam-se orientações como, a "opcionalidade" para o curso integrado em informática (que elimina de vez os ganhos advindos do estágio) e a baixa carga horária implementada, que fatalmente limita o alcance dos objetivos do estágio supervisionado e a formação profissional do discente.

Diante do modo como é operacionalizado o estágio supervisionado no IFNMGJanuária e dentro do cenário já apresentado no Capítulo 1, onde se observou a perda do caráter profissionalizante apontado pelo desinteresse dos alunos do Ensino Integrado pela parte profissionalizante e também nas falhas de operacionalização do estágio supervisionado em diversas instituições (até mesmo nas Universidades Federais), vê se importante investigar o caráter profissionalizante da política pública do ensino integrado na Instituição.

\subsection{Metodologia}

A pesquisa utilizou-se da abordagem de metodologia mista explanatória sequencial no IFNMG-Januária. Conforme Creswell (2007) a coleta de diversos tipos de dados (quantitativos e qualitativos) garante um melhor entendimento do problema pesquisado, reconhecido que todos os métodos possuem limitações, os pesquisadores entendiam que os vieses inerentes a um método poderiam neutralizar os vieses oriundos de outros métodos. (CRESWELL, 2007, p. 32- 33)

Spratt, Walker e Robison (2004, p. 6) corroboram com Creswell (2007) afirmando que a utilização de múltiplas abordagens poderá contribuir mutuamente 
para as potencialidades de cada método utilizado, além de suprir as deficiências deles, proporcionando respostas mais abrangentes às questões de pesquisa, indo além das limitações interpretativas quando se utiliza uma única abordagem.

Um projeto de métodos mistos é útil para conseguir o melhor das técnicas quantitativas e qualitativas. Creswell (2007, p.33) explica que um estudo utilizando métodos mistos "pode começar com um método quantitativo, no qual teorias ou conceitos sejam testados, e depois prosseguir com um método qualitativo, envolvendo exploração detalhada de poucos casos ou de poucas pessoas".

Assim sendo, definimos que os resultados quantitativos acerca das teorias do fenômeno "perda do caráter profissionalizante" e dos conceitos e operacionalização do estágio supervisionado, seriam depois explorados mais profundamente com a abordagem qualitativa com os atores mais envolvidos nesses pontos junto dos alunos: os professores que ocupam cargos de gestão e coordenação.

Creswell (2007, p.18) explica que o modelo explanatório sequencial se caracteriza por "uma fase inicial de coleta e análise de dados quantitativos, seguida por uma fase de coleta e análise de dados qualitativos" integrando os resultados na interpretação do estudo.

A estratégia explanatória sequencial é a mais direta das seis técnicas de métodos mistos. Ela é caracterizada pela coleta e análise de dados quantitativos, seguida pela coleta e análise de dados qualitativos. Geralmente dá-se prioridade para os dados quantitativos, e os dois métodos são integrados durante a fase de interpretação do estudo. [...] O objetivo do projeto explanatório sequencial geralmente é o de usar resultados qualitativos para auxiliar na explicação e na interpretação de resultados de um estudo primariamente quantitativo. Ele pode ser bastante útil quando surgem resultados inesperados de um estudo quantitativo (Morse, 1991). Nesse caso, a coleta de dados qualitativos que segue pode ser usada para examinar esses resultados surpreendentes com mais detalhes. A natureza direta desse projeto é um de seus principais pontos fortes. Ele é fácil de implementar porque os passos seguem estágios claros e distintos. Além disso, as características do projeto o tornam fácil de descrever e relatar. CRESWELL (2007, P.217)

Portanto este estudo deu prioridade ao aspecto quantitativo, integrando os resultados das duas fases durante a fase de interpretação. 
A estratégia explanatória sequencial se mostrou adequada a esta pesquisa. Por exemplo, muitos discentes informaram no questionário estruturado que o acompanhamento do estagiário pelo professor orientador se dava apenas por meio de assinaturas no relatório de atividades, e não através de um acompanhamento efetivo como requer a Lei do Estágio, o que nos estimulou a formular uma questão para a entrevista no intuito de compreender o porquê isso acontece.

No intuito de melhor sustentar nossas interpretações também fizemos uso de dados extraídos do questionário de egressos do IFNMG, confrontando a expectativa e motivação discente com o verdadeiro caminho seguido pelos egressos da Instituição.

Utilizando o sistema de notação sugerido por Johnson \& Onwuegbuzie (2004) para a metodologia mista, esta pesquisa se descreve da seguinte forma: QUAN $\rightarrow$ qual. Essa notação informa que a pesquisa fará uso de ambos os métodos (QUAN: quantitativo e qual: qualitativo), a seta " $\rightarrow$ " indica uso sequencial dos métodos (nesse estudo em específico, primeiro o método quantitativo e depois o qualitativo) e que a ênfase será no estudo quantitativo (“QUAN" em maiúsculo). O modelo gráfico proposto por Creswell (2007) que descreve a estratégia deste projeto é exibido abaixo:

Figura 3 Notação Abordagem Mista

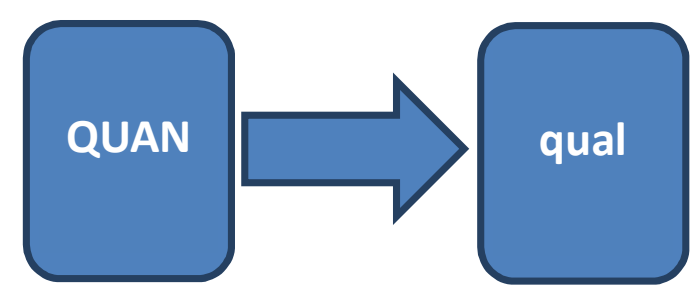




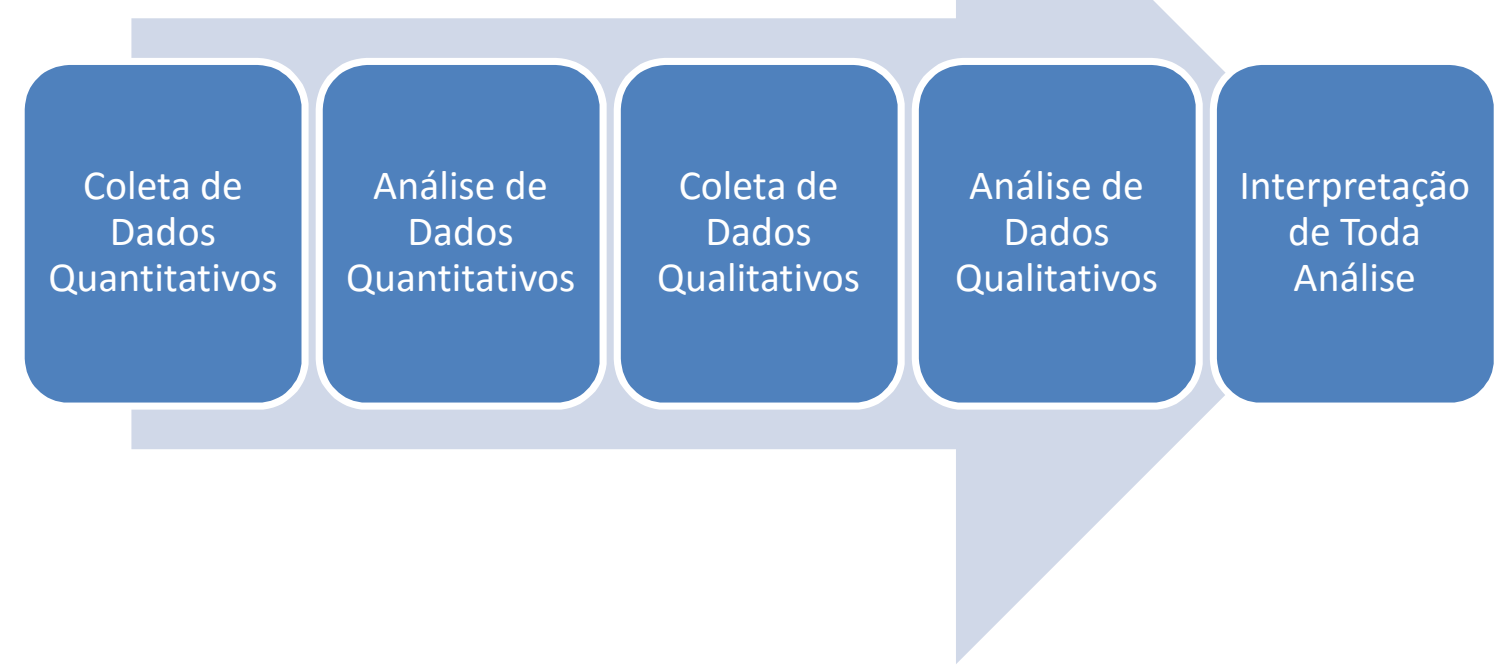

Fonte: Elaboração própria, adaptado de Creswell(2007, p.217),

\subsubsection{População, Coleta e Análise de Dados}

No primeiro semestre de 2015 , período da coleta dos dados quantitativos, segundo a secretaria de registros acadêmicos, o IFNMG-Januária contava com o registro de 484 alunos matriculados, distribuídos em 16 turmas como mostra o quadro abaixo:

Quadro 1 - Turmas de Ensino Integrado Campus Januária

\begin{tabular}{|l|l|l|l|}
\hline & $1^{\circ}$ Ano & $2^{\circ}$ Ano & $3^{\circ}$ Ano \\
\hline Agropecuária & Turmas A, B e C & Turmas A e B & Turmas A e B \\
\hline Informática & Turmas A e B & Turmas A e B & Turmas A e B \\
\hline Meio Ambiente & Turmas A e B & Turma A (única) \\
\hline \multicolumn{3}{|c}{ Fonte: Documentação Interna IFNMG-Januária }
\end{tabular}

De modo a obter maior precisão na análise dos dados, conferir maior anonimato aos participantes e também pelo fato dos recursos tecnológicos facilitarem a coleta dos dados, optamos em trabalhar com todas as turmas da instituição, concomitante a 
análise dos dados da pesquisa de campo também extraímos informações dos dados do questionário de egressos do IFNMG. Para termos acesso ao banco de dados de egressos, elaboramos ofício a Direção de Extensão do IFNMG nos comprometendo a ter os devidos cuidados éticos, como não divulgar nomes de alunos, documentos pessoais etc. O ofício foi então encaminhado para apreciação na Procuradoria Federal Junto ao IFNMG e o acesso liberado.

Para a parte qualitativa fizemos entrevistas semiestruturadas com os professores. As questões foram pontuais, elaboradas a partir do resultado da análise do questionário discente em determinados pontos em que se observou ser importante aprofundar a análise.

Portanto, diante da metodologia da pesquisa proposta, o projeto se dividiu em duas fases: Fase 1 - Quantitativa e Fase 2-Qualitativa. Porém, antes de irmos definitivamente a campo, fizemos uma Pesquisa Piloto com os discentes para nos certificarmos que nossos objetivos seriam alcançados.

Abaixo explicitaremos as fases da Pesquisa, a Pesquisa Piloto e em seguida os resultados da Pesquisa de Campo.

\subsubsection{Fase 1-Quantitativa}

Para uma coleta rápida e eficiente, tanto para a pesquisa piloto quanto para a pesquisa definitiva, nós utilizamos o LimeSurvey, que é um ambiente desenvolvido com o objetivo de preparar, publicar e coletar respostas de questionários eletrônicos online, essa ferramenta nos permitiu, através de instruções condicionais, definir como as questões seriam exibidas. Outra característica muito importante dessa ferramenta é a possibilidade de exportar os dados da pesquisa para diversos formatos, inclusive o formato "sps" do software SPSS (Statistical Package for Social Science) utilizado nessa pesquisa.

Para maior segurança dos dados e garantia de disponibilidade dos questionários no momento da pesquisa, o ambiente LimeSurvey ficou hospedado em servidor de conta premium particular, porém existe o serviço gratuito que contempla todas as funcionalidades. 
O questionário estruturado feito com o LimeSurvey constou de cinquenta e duas questões para os cursos integrados Agropecuária e Meio Ambiente e cinquenta e três questões para o curso de Informática, divididas em duas partes:

1) Informações gerais dos alunos, Motivação/Interesse pelo Ensino Técnico Integrado, Percepção do Ensino Integrado, avaliação da Instituição e curso e Expectativas após a conclusão do curso.

2) Estágio Supervisionado.

A primeira parte era comum a todos os cursos, já a segunda parte, o estágio supervisionado, como era esperado que os alunos do primeiro, e até mesmo do segundo ano do curso não saberiam opinar sobre o estágio supervisionado o conjunto de questões ficou bem reduzido para quem respondesse "não" na questão "Você sabe o que é estágio supervisionado?", o mesmo para todos os anos do curso de informática, já que o estágio não é obrigatório e os alunos não demonstram interesse em fazê-lo ou terem maior conhecimento sobre a atividade. Para os três cursos, caso o aluno respondesse "sim" e não tivesse no mínimo $8 \mathrm{~h}$ de estágio supervisionado, outras questões que dependiam de uma maior experiência do estagiário também eram ocultadas, várias outras condicionais foram implementadas, todas as questões, inclusive os comandos condicionais, podem ser consultadas no apêndice dessa dissertação.

O questionário foi elaborado com uma linguagem de fácil entendimento evitando palavras pouco comuns ao vocabulário discente, como por exemplo, foi utilizado o termo "disciplinas do ensino médio" ao invés de "disciplinas propedêuticas".

Mesmo na pesquisa piloto os questionários foram exaustivamente testados e aprimorados antes de serem aplicados, tanto na redação, com palavras simples de se entender, como nos comandos condicionais, pois é necessário ter certeza que todos os caminhos direcionados pelos comandos condicionais sejam percorridos, esse foi o ponto que mais demandou tempo na elaboração dos questionários.

Estando os questionários exaustivamente testados, iniciamos a pesquisa encaminhado os discentes para o laboratório de informática da Instituição previamente preparado para recebê-los, inclusive foi tomado o cuidado de simplificar o endereço eletrônico do questionário eletrônico a poucas letras utilizando o Google URL 
Shortener ${ }^{7}$, dessa forma ganhamos agilidade no processo, mesmo para alunos que por ventura tivessem pouca habilidade com o teclado.

Antes dos discentes começarem a responder foi esclarecido o propósito da pesquisa e garantido o anonimato do respondente, e também que eram livres para a qualquer momento deixarem a pesquisa, um termo de consentimento em duas vias foi assinado pelos discentes do qual eles ficaram com uma cópia.

Os questionários aplicados com a ferramenta LimeSurvey foram exportados para o formato ".sps", que é o formato proprietário do software SPSS (Statistical Package for Social Science $)^{8}$ que nós utilizamos para analisar os dados quantitativos. O SPSS pode gerar automaticamente tabelas e gráficos, agilizando muito a disposição dos dados tanto em frequências quanto em tabelas de referência cruzada, conferindo maior precisão e confiabilidade nas interpretações.

\section{Sobre a pesquisa Piloto ou Pré-Teste}

Como dito anteriormente, antes de irmos definitivamente a campo, fizemos uma pesquisa piloto.

Segundo Lakatos e Marconi (2003, p.227), a pesquisa piloto tem como principal função testar o instrumento de coleta de dados, anotando "as reações do entrevistado, sua dificuldade de entendimento, sua tendência para esquivar-se de questões polêmicas ou 'delicadas', seu embaraço com questões pessoais etc”. Dessa forma, segundo a autora, a pesquisa-piloto evidenciará ainda:

${ }^{7}$ https://goo.gl/

${ }^{8}$ Maiores informações sobre o SPSS: http://www-01.ibm.com/software/br/analytics/spss/ 
[...] ambiguidade das questões, existência de perguntas supérfluas, adequação ou não da ordem de apresentação das questões, se são muito numerosas ou, ao contrário, necessitam ser complementadas etc. Uma vez constatadas as falhas, reformula-se o instrumento, conservando, modificando, ampliando, desdobrando ou alterando itens; explicitando melhor algumas questões ou modificando a redação de outras; perguntas abertas (e uma grande parte deve ser aberta na pesquisa-piloto) podem ser fechadas, utilizando as próprias respostas dos entrevistados, desde que não haja muita variabilidade.(LAKATOS; MARCONI, 2003, p. 227-228)

Lakatos e Marconi (2003) informam ainda que em relação ao questionário o pré-teste poderá evidenciar se ele apresenta ou não três elementos de suma importância que são: a fidedignidade, a validade e a operatividade. E explicita:

Fidedignidade: obter-se-ão sempre os mesmos resultados, independentemente da pessoa que o aplica?

Validade: os dados obtidos são todos necessários à pesquisa? Nenhum fato, dado ou fenômeno foi deixado de lado na coleta?

Operatividade: o vocabulário é acessível a todos os entrevistados, e o significado das questões é claro?

Os dois últimos elementos citados por Lakatos e Marconi (2003) foram de extrema importância para este estudo.

\subsubsection{Fase 2- Qualitativa}

Seguindo a proposta de Creswell (2007) essa segunda fase da pesquisa foi realizada para auxiliar na explicação e na interpretação dos resultados quantitativos, principalmente nas questões sobre o estágio supervisionado, assim sendo, fizemos entrevistas semiestruturadas com quatro professores que ocupam cargos de gestão e coordenação de cursos.

As perguntas das entrevistas foram previamente formuladas a partir dos resultados do questionário discente, e em alguns momentos, embora poucos, foi interessante estender ou alterar a ordem das perguntas para melhor extrair e 
aprofundar as informações trazidas pelos discentes, caracterizando então uma entrevista semiestruturada conforme descreve Cruz Neto (1999).

Em geral, as entrevistas podem ser estruturadas e nãoestruturadas, correspondendo ao fato de serem mais ou menos dirigidas. Assim, toma-se possível trabalhar com a entrevista aberta ou não-estruturada, onde o informante aborda livremente o tema proposto; bem como com as estruturadas que pressupõem perguntas previamente formuladas. Há formas, no entanto, que articulam essas duas modalidades, caracterizando-se como entrevistas semiestruturadas. (CRUZ NETO,1999, p.58)

A escolha dos gestores deu pela sua responsabilidade na organização escolar (é a interseção na instituição entre os alunos, a equipe de ensino e a comunidade) com foco no aprendizado dos alunos, portanto abarcou o tema pesquisado com uma visão diferenciada, mais abrangente.

No caso dos coordenadores, que também são professores, além de terem contato direto com os discentes como professores de disciplinas e também como orientadores de estágio supervisionado, são também responsáveis por aprovar todos os planos de estágio de seus cursos, portanto possuem elevado conhecimento tanto no perfil de seus discentes quanto na operacionalização do estágio supervisionado.

Antes do início da entrevista foi esclarecido o propósito da pesquisa e garantido o anonimato do respondente, os participantes foram identificados nesta pesquisa como P1, P2, P3 e P4, um termo de consentimento em duas vias foi assinado pelos docentes do qual eles ficaram com uma cópia.

As entrevistas foram gravadas utilizando o software Audacity 9 para o sistema operacional Windows no notebook e auxílio de um microfone externo, em seguida foram transcritas.

O software Audacity é gratuito e possui funcionalidade de edição, gravação, reprodução e importação/exportação do áudio em diversos formatos, de fácil uso, foi mais que suficiente para registrar as entrevistas.

${ }^{9}$ Maiores informações e download do Audacity: http://sourceforge.net/projects/audacity/ 
Como dito, as questões elaboradas para as entrevistas foram criadas a partir das respostas dos questionários dos discentes, principalmente quanto ao estágio supervisionado para melhor elaborar o Produto Técnico.

Tivemos como referência para a análise dos dados qualitativos, a análise de conteúdo proposta por Bardin (2011), que a define como:

Um conjunto de técnicas de análise das comunicações visando obter por procedimentos sistemáticos e objetivos de descrição do conteúdo das mensagens indicadores (quantitativos ou não) que permitam a inferência de conhecimentos relativos às condições de produção/recepção (variáveis inferidas) dessas mensagens. (BARDIN, 2011, P.48)

Para Flick (2013, p.134) "a análise de conteúdo é um procedimento clássico para analisar materiais de texto de qualquer origem, de produtos da mídia a dados de entrevistas".

Bardin (2011) organiza a análise em torno de três polos cronológicos:

1) pré-análise;

2) exploração do material;

3) tratamento dos resultados, a inferência e a interpretação.

Na fase inicial, pré-análise, selecionamos partes importantes de todo material obtido na pesquisa (resultados quantitativos da pesquisa discente, as entrevistas, Leis, Pareceres, Documentação Interna...) fizemos uma leitura "flutuante" (BARDIN, 2011 , p. 126) que pouco a pouco foi se tornado mais precisa.

Na segunda fase, exploração do material, realizamos uma leitura mais atenta e, quando necessário, uma nova escuta nas entrevistas realizadas, assinalando os trechos que tinham relação com os objetivos da pesquisa.

As respostas para uma mesma questão foram agrupadas em documentos separados, nesses documentos identificamos primeiro o tema e logo em seguida as palavras que apareciam com maior frequência e sua relação contextual.

A terceira fase (tratamento de dados, ou seja, interpretação e/ou inferência) especificamos as categorias a partir dos conteúdos da fase anterior. A análise final, desta fase qualitativa, foi baseada nas significações das palavras e frases que 
denotavam as opiniões dos entrevistados, revelando suas crenças e percepções acerca do ensino médio integrado e em especial do estágio supervisionado.

\subsubsection{Interpretação de Toda Análise: Quantitativa + Qualitativa}

Creswell (2007, p.224) atenta que "os estudos de métodos mistos podem não ser familiares para o público" e que "é útil fornecer alguma orientação sobre a maneira como o relatório final será estruturado". Assim sendo, seguimos as orientações do autor transcritas abaixo:

Para um estudo sequencial, os pesquisadores de métodos mistos geralmente organizam o relatório de procedimentos em coleta e análise de dados quantitativos, seguidas por coleta e análise de dados qualitativos. Depois, nas conclusões ou na fase de interpretação do estudo, o pesquisador comenta sobre como os resultados qualitativos ajudaram a elaborar ou ampliar os resultados quantitativos. Alternativamente, a coleta e a análise de dados qualitativos podem vir primeiro, seguidas pela coleta e análise de dados quantitativos. Qualquer que seja a estrutura, o autor geralmente apresenta o projeto com duas fases distintas, com cabeçalhos separados para cada fase. (CRESWELL, 2007, p.224)

Baseados na interpretação de toda análise (Quantitativa e Qualitativa) e também em todo material estudado na dissertação, elaboramos um Produto Técnico com Diretrizes Fundamentais Para Implantação e Execução do Estágio Supervisionado em Cursos Técnicos Integrados, no intuito de colaborar com a valorização do estágio supervisionado e consequentemente fortalecer o caráter profissionalizante da Política Pública do Ensino Integrado. 


\subsection{Resultados da Pesquisa de Campo}

Nessa seção serão apresentados os achados da pesquisa, relacionando-os com os objetivos estabelecidos para responder à nossa formulação inicial, corroborando ou não a nossa hipótese.

\subsubsection{A aplicação dos questionários na pesquisa piloto}

A Pesquisa Piloto contou com a aplicação de 136 questionários eletrônicos (LimeSurvey), englobando todos os cursos integrados (Informática, Meio Ambiente e Agropecuária) e também todos os anos $\left(1^{\circ}, 2^{\circ}\right.$ e $\left.3^{\circ}\right)$, sendo uma turma (A,B ou $\left.C\right)$ de cada ano, inclusive com turmas praticamente completas, que foram $1^{\circ}, 2^{\circ}$ e $3^{\circ}$ anos de Informática, $3^{\circ}$ Ano de Agropecuária e $2^{\circ}$ Ano de Meio Ambiente, pois os professores que estavam ministrando suas aulas, gentilmente e cooperativamente, liberaram os alunos para colaborarem com o aperfeiçoamento da pesquisa.

Os restantes das turmas de Agropecuária ( $1^{\circ}$ Ano e $2^{\circ}$ Ano) e Meio Ambiente $\left(1^{\circ}\right.$ Ano) os alunos estavam ociosos por terminarem atividades avaliativas e foram convidados a colaborarem com o refinamento do questionário.

Ao entrarem no laboratório o endereço eletrônico abreviado pelo Google URL Shortener já se encontrava no quadro e no formulário impresso entregue a cada aluno com orientações do objetivo da pesquisa piloto e espaço para fazerem suas sugestões.

Talvez pela preocupação em simplificar os termos utilizados na formulação das perguntas foram raras às vezes em que algum aluno não entendia o enunciado, ainda assim, antes que alguns alunos deixassem o laboratório de informática, particularmente Ihes era perguntado como haviam compreendido determinadas questões cruciais da pesquisa, para nos certificarmos que haviam entendido corretamente. Nos dizeres de muitos discentes "Estava muito bem explicadinho". 
Portanto, a alteração nos questionários se limitou com sugestões de trocar de posições algumas questões e inclusão de opções como "Talvez" e "Não Sei Opinar".

O questionário teste foi exportado para o formato do programa SPSS e executado, os dados foram analisados e nos exprimiu o possível resultado da pesquisa.

A quantidade e variedade de discentes que participaram da pesquisa piloto aliada a estabilidade, praticidade e confiabilidade das ferramentas LimeSurvey e SPSS nos deu a confiança necessária para aplicar definitivamente o questionário a toda à população discente dos cursos integrados com segurança.

\subsubsection{Análise da Fase Quantitativa}

Segundo a secretaria de registro escolar do IFNMG-Januária, havia 484 alunos regularmente matriculados, ao fim da aplicação dos questionários o LimeSurvey contabilizou 411 questionários completamente e parcialmente preenchidos, distribuídos da seguinte forma:

Tabela 2 Quantitativo de Questionários Aplicados

\begin{tabular}{lccc}
\hline & Completo & Parcial & Total \\
\hline Meio Ambiente & 85 & 6 & 91 \\
Agropecuária & 179 & 1 & 180 \\
Informática & 133 & 7 & 140 \\
Total & 397 & 14 & 411 \\
\hline \multicolumn{4}{c}{ Fonte: Pesquisa de Campo 2015 }
\end{tabular}

A distribuição dos discentes do ensino integrado do IFNMG-Januária por ano em curso é mostrada no gráfico 2 . 
Gráfico 2 Distribuição dos Discentes por ano em curso

Distribuição dos Discentes por ano em curso

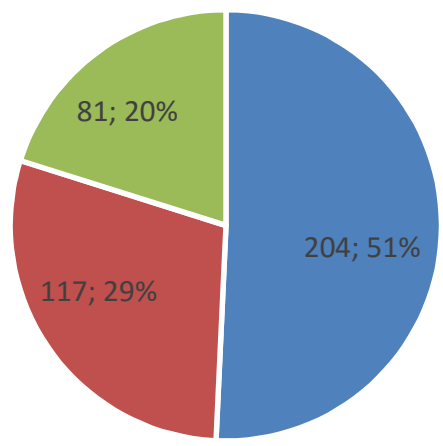

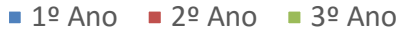

Os tempos de conclusão do questionário também foram reportados pela ferramenta:

- Meio Ambiente, Tempo médio de entrevista: 12 min. 13 seg., Mediana:11 $\min .52$ seg. ;

- Agropecuária, Tempo médio de entrevista:12 min. 21 seg., Mediana: 11 min. 59 seg.;

- Informática Tempo médio de entrevista:10 min. 25 seg., Mediana:10 min. 15 seg.

Como dito anteriormente, essa etapa da pesquisa objetivou conhecer a Motivação e Expectativa dos estudantes do Ensino Integrado do IFNMG-Campus Januária no intuito de melhor compreender a realidade e expectativas desses sujeitos quanto à política pública.

Em relação às informações gerais dos alunos, o questionário registrava questões sobre idade, sexo, cor/raça, ano cursado, regime (interno, externo ou semiinterno).

As idades dos alunos são condizentes ao ano cursado não apresentando quantidade significativa de defasagem idade/série. Os resultados mostram que quanto à cor/raça dos estudantes a maioria considera-se pardos nos três cursos 
(Agropecuária: 65,9\%, Informática: 58,6\% e Meio Ambiente: 65,9\%), já em relação ao gênero temos a seguinte distribuição para o gênero masculino: Agropecuária= 57,2\%; Informática $=58,6 \%$ e Meio Ambiente $=39,6 \%$.

Quanto a Motivação, Interesse e Perspectivas

Os gráficos abaixo representam em porcentagem as respostas dos discentes para a questão: "Dentre os FATORES QUE ESTIVERAM PRESENTES NA ESCOLHA PELO ENSINOINTEGRADO, responda o quanto cada um deles INFLUENCIOU sua decisão pelo curso: ".

Gráfico 3 Motivação/Interesse em Prosseguimento nos Estudos

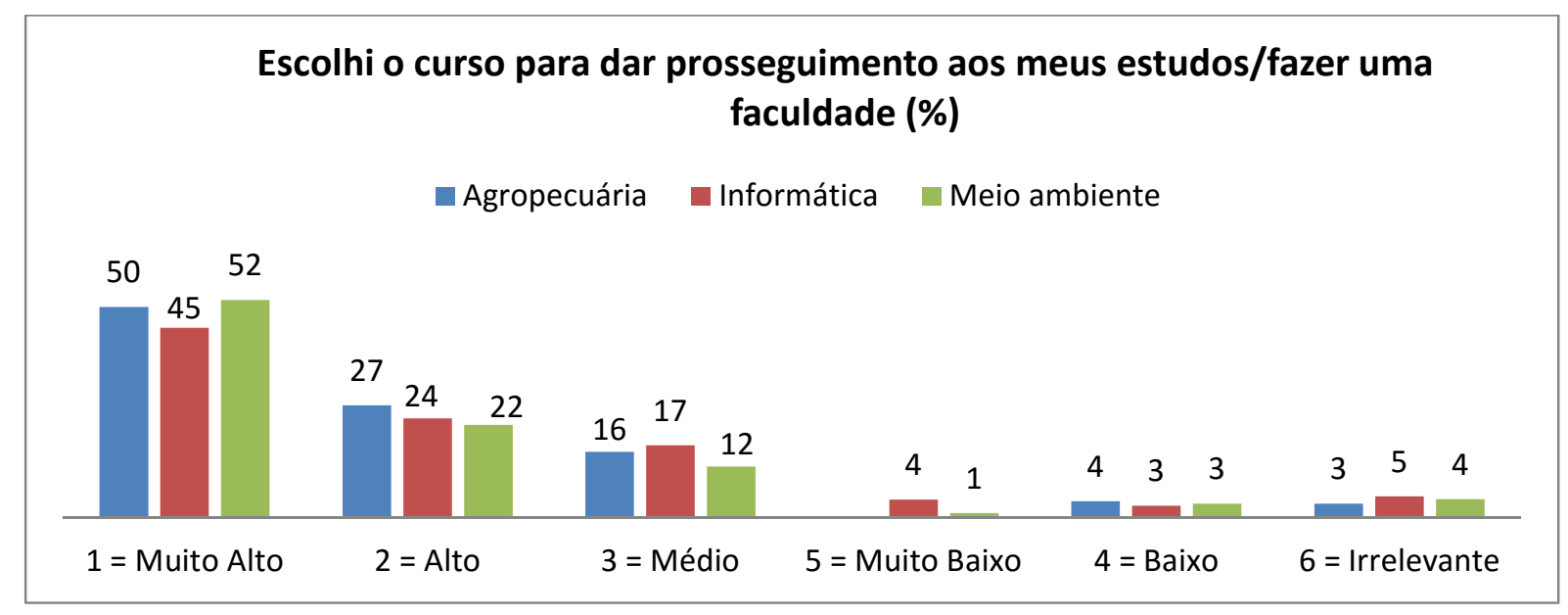

Fonte: Pesquisa de Campo 2015

Gráfico 4 Motivação/Interesse no Mercado de Trabalho

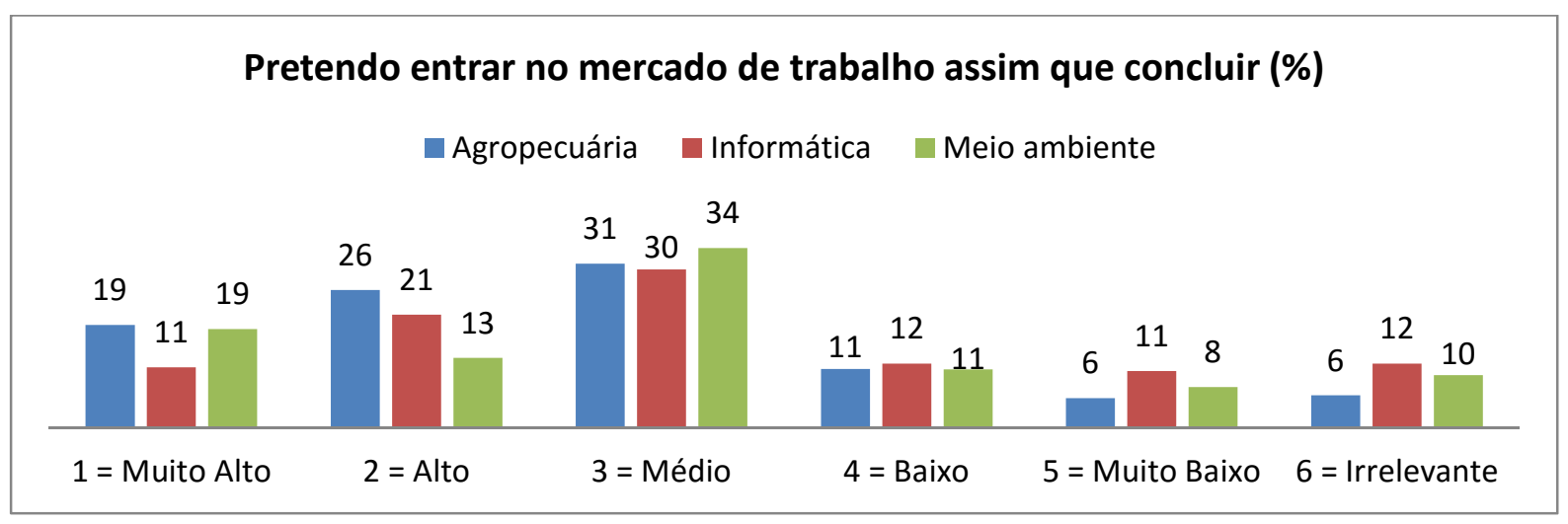

Fonte: Pesquisa de Campo 2015 
Observamos que o fator prosseguimento nos estudos foi o que mais influenciou os discentes a escolherem o ensino integrado, pois a soma dos índices "Muito Alto" e "Alto" obteve maior porcentagem para os três cursos, sendo Agropecuária 77\%, Informática $69 \%$ e Meio Ambiente $74 \%$, contra 45\%, 32\% e 32\% no fator "entrar no mercado de trabalho assim que concluir" respectivamente.

Para a mesma questão, somando as porcentagens dos índices "Muito Alto" e "Alto", o fator "Necessidade de obtenção de diploma de ensino médio" (com Agropecuária: 79,9\%, Informática: $82,5 \%$ e Meio Ambiente: 80,2\%) também prevaleceu sobre o fator "Necessidade de obtenção de diploma de curso técnico" (com respectivamente $49,7 \%, 38 \%$ e $43 \%$ ) destaque para o curso de Informática que obteve maior discrepância.

Os alunos procuram, assim como vimos nas outras instituições no capítulo 01 , o ensino propedêutico mais do que a especificidade e necessidade do curso técnico.

Atentamos ao leitor que daqui em diante (em muitas análises) não será representado graficamente as porcentagens dos índices "Médio", "Baixo", "Muito Baixo" e "Irrelevante", para os resultados das questões elaboradas como a mostrada nos gráficos 3 e 4 . O motivo é que somente os índices "Muito Alto" e "Alto" foram suficientes para compreendermos os resultados das questões seguintes que possuem a mesma estruturação. Portanto, em toda análise que se der com a soma dos índices "Muito Alto" e "Alto" só será informada a porcentagem desses índices, logo atentamos que, a porcentagem total para a soma dos índices "Muito Alto" e "Alto" não alcançará $100 \%$, devido o restante estar distribuída nos índices "Médio", "Baixo", "Muito Baixo" e "Irrelevante". Dessa forma conseguimos representar no espaço de um gráfico até seis resultados (por exemplo ver o Gráfico 7) de questões de mesmo tipo estrutural que ocupariam o espaço de seis gráficos do tamanho do gráfico 4, assim sendo, o foco no resultado ficou melhor observável e de fácil comparação, além de diminuir consideravelmente a extensão desse capítulo.

As informações contidas no gráfico abaixo representam os resultados das questões: "Se o IFNMG oferecesse SOMENTE O ENSINO MÉDIO, sem a obrigatoriedade de fazer o ensino Técnico, você se interessaria em cursar somente o ensino médio?" e "Se o IFNMG oferecesse SOMENTE o ENSINO TÉCNICO, sem a 
obrigatoriedade de fazer o ensino Médio, você se interessaria em cursar somente o ensino técnico? ", as opções eram Sim, Não e Talvez.

Gráfico 5 Interesse em Cursar Somente o Médio ou Técnico

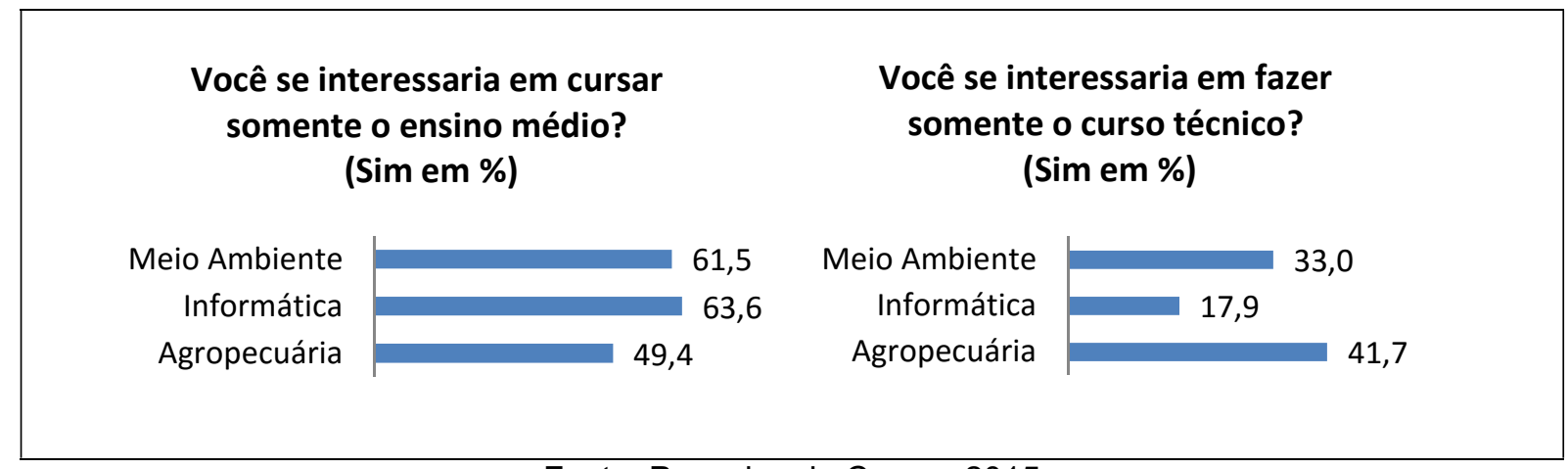

Fonte: Pesquisa de Campo 2015

Assim como nos dados anteriores o interesse no propedêutico permanece bem mais acentuado nos cursos Meio Ambiente e Informática, o curso de agropecuária mantém-se mais equilibrado quanto aos dois eixos (propedêutico x profissionalizante).

É interessante saber o direcionamento que os pais dão a esses discentes com a questão: "Os seus pais incentivam você: ". A soma dos valores "Alto" e "Muito Alto" é mostrada num único gráfico para as opções: "A terminar o curso e ir para o mercado de trabalho da área técnica" e "A terminar o curso e tentar o vestibular para os cursos superiores".

Gráfico 6 Orientação dos Pais Vestibular x Trabalho

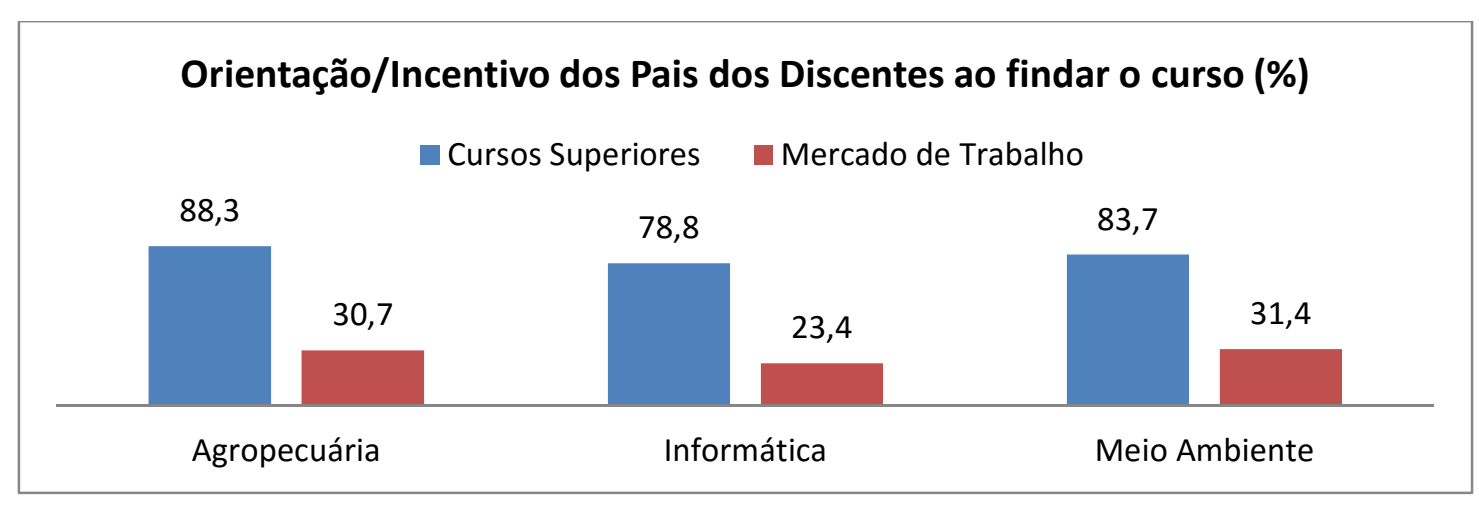

Fonte: Pesquisa de Campo 2015 
Vemos então que a maior preferência dos pais para seus filhos também é pelo eixo prosseguimento em estudos superiores e não por uma necessidade de profissionalização de nível médio.

Sabemos até o momento a direção tomada pelos alunos e seus pais, mas e quanto a Instituição de Ensino? Na percepção dos alunos possui também algum direcionamento? Para extrair essa informação do aluno confrontamos as perguntas "Quanto à instituição te prepara para o mercado de trabalho? " e "Quanto à instituição te prepara para o vestibular? " e, depois, resolvemos comparar com o seu desejo de formação com as perguntas "Quanto você quer se preparar para o vestibular?" confrontando com "Quanto você quer trabalhar como técnico de sua área de formação? ". A soma dos indicativos "Muito Alto" e "Alto" é mostrada no gráfico 7:

Gráfico 7 Formação dada Pela Instituição x Desejo de Formação do Aluno

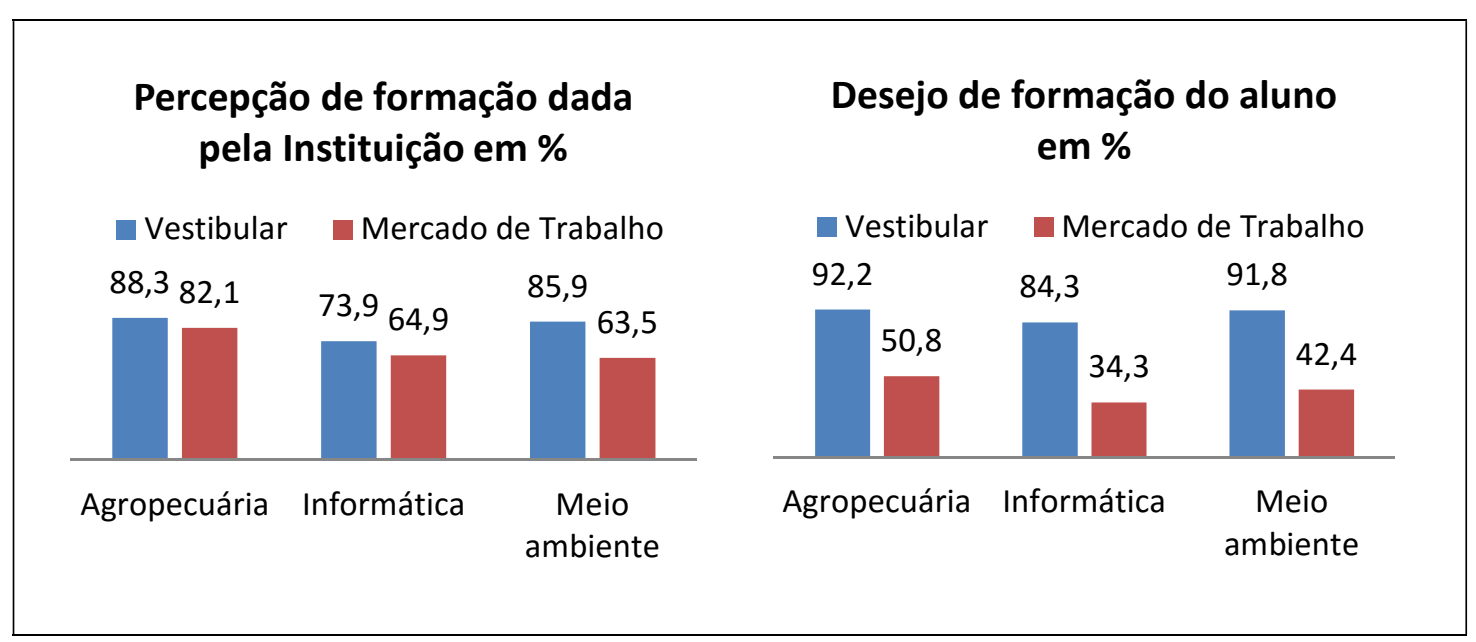

Fonte: Pesquisa de Campo 2015

Vemos que existe na percepção do discente um direcionamento da instituição também pelo eixo prosseguimento nos estudos, mas não é uma diferença tão discrepante quanto à predileção extraída dos discentes e dos pais vista anteriormente e também pelo seu desejo de se preparar para o vestibular.

Como ficou então o maior objetivo dos alunos após concluírem o curso? Para isso fizemos a pergunta: "Qual o seu maior objetivo a ser alcançado após a conclusão do curso? ". O resultado mostra a soma dos índices "Muito Alto" e "Alto", para as duas opções constantes no gráfico: 
Gráfico 8 Maior objetivo dos alunos após a conclusão do curso

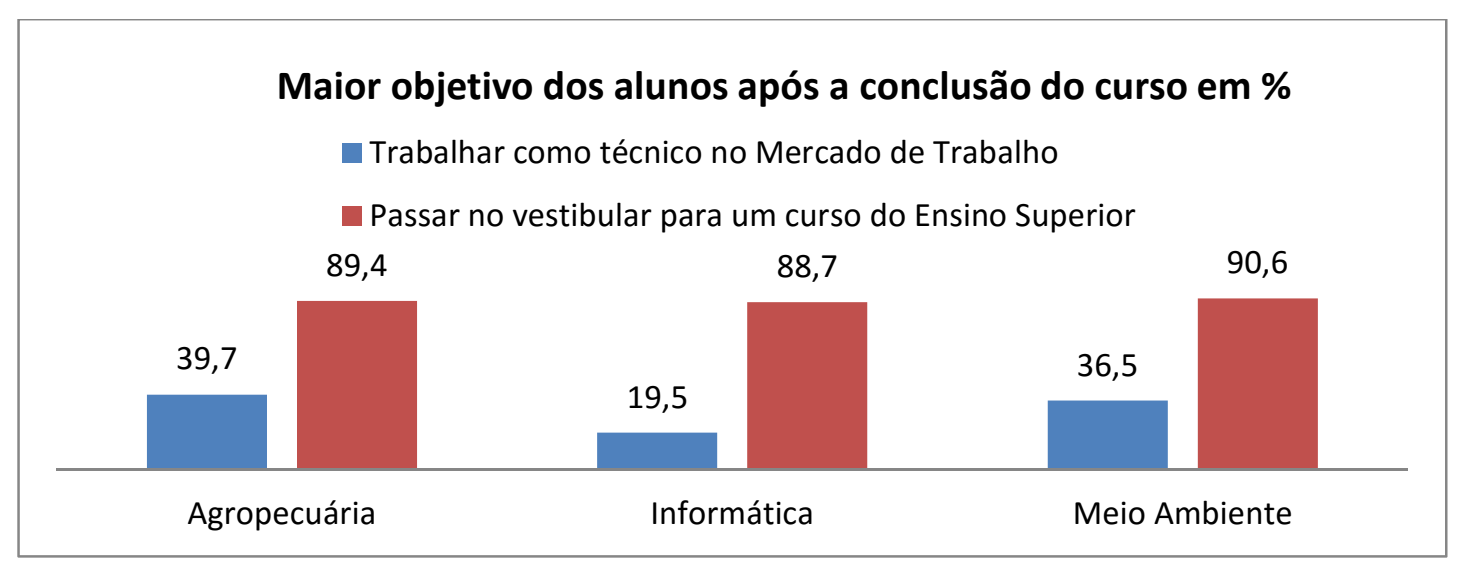

Fonte: Pesquisa de Campo 2015

De acordo com os resultados anteriores ocorreu o esperado, se considerarmos somente os alunos do $3^{\circ}$ ano que teoricamente estão mais amadurecidos quanto a sua decisão, os resultados são ainda mais expressivos, vejamos no gráfico 9 abaixo (obs.: incluímos mais uma opção para análise, "Trabalhar como técnico e ao mesmo tempo fazer faculdade").

Gráfico 9 Maior objetivo dos alunos do $3^{\circ}$ Ano Informática após a conlusão do curso

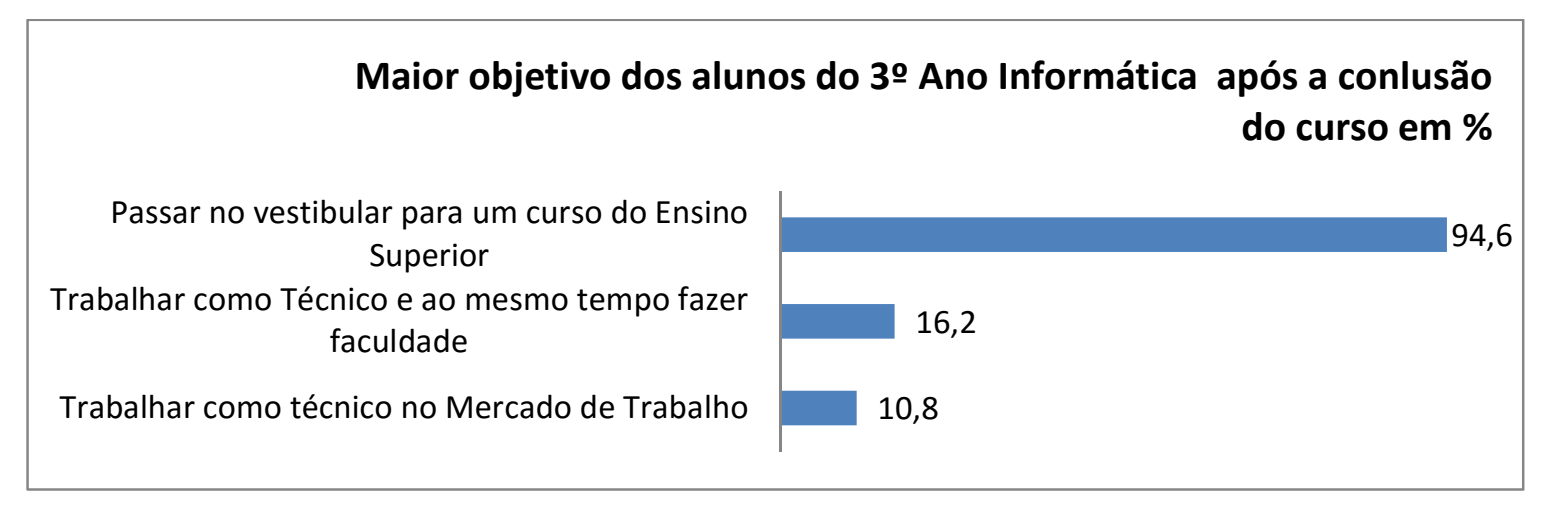

Fonte: Pesquisa de Campo 2015 
Gráfico 10 Maior objetivo dos alunos do $3^{\circ}$ Ano Agropecuária após a conclusão do curso

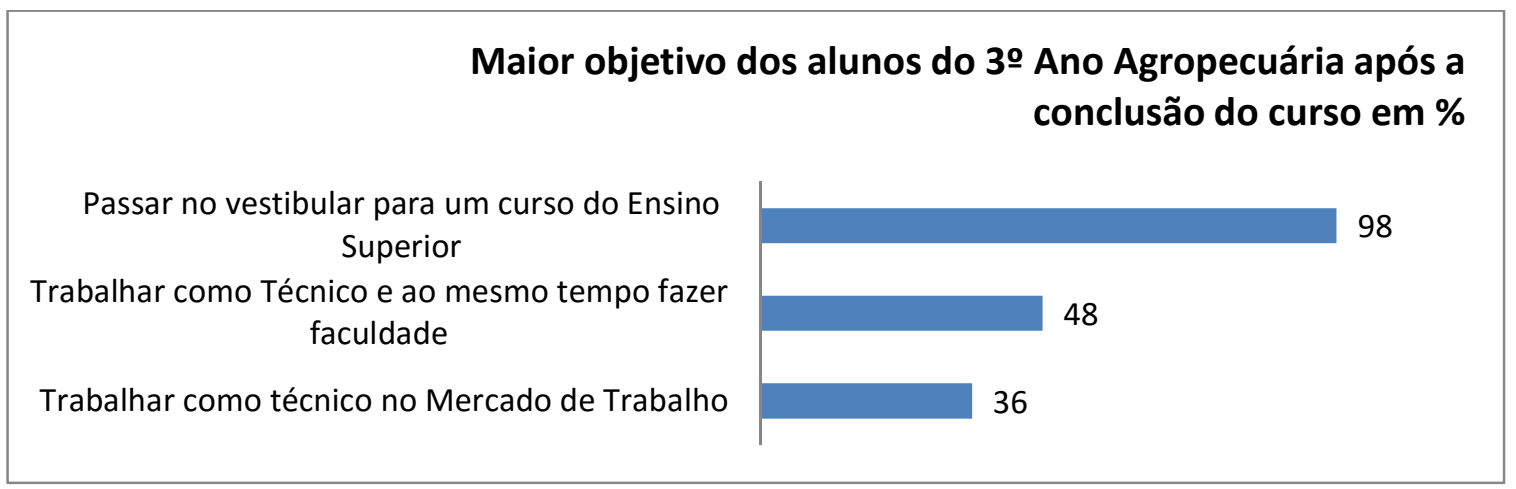

Fonte: Pesquisa de Campo 2015

Vemos que no curso de informática, possivelmente, os egressos farão pouco uso da habilitação profissional, enquanto que no curso de agropecuária quase que metade do quantitativo dos discentes (48\%) possivelmente utilizará da habilitação profissional ao mesmo tempo em que continuam seus estudos no ensino superior, fazendo assim melhor uso da política pública, observamos também uma porcentagem significativa (36\%) dos discentes de Agropecuária que atribuíram índices "Muito Alto" e "Alto" o objetivo de ingressar no mercado de trabalho após a conclusão do curso.

Uma vez que, ao que tudo indica, esses discentes irão concorrer às vagas no ensino superior ao término do curso, será que desejam concorrer para o curso superior em sua área de formação técnica, verticalizando assim os estudos como objetiva o itinerário formativo da política pública? As perguntas individuais de cada curso foram colocadas numa única pergunta na tabela 3 (abaixo).

Tabela 3 Itinerário Formativo

Você deseja fazer um Curso Superior (faculdade) na área do curso técnico em Agropecuária/Informática/Meio Ambiente?

\begin{tabular}{cccc} 
& Sim & Não & Estou Indeciso \\
\hline Agropecuária & $84(46,70 \%)$ & $33(18,30 \%)$ & $62(34,40 \%)$ \\
Informática & $30(21,40 \%)$ & $68(48,60 \%)$ & $35(25 \%)$ \\
Meio Ambiente & $20(22 \%)$ & $21(23,10 \%)$ & $44(48,40 \%)$ \\
\hline
\end{tabular}

Fonte: Pesquisa de Campo 2015 
Os discentes do curso de Agropecuária destacam-se novamente com um bom aproveitamento no itinerário formativo, e também, novamente, o curso de Informática destaca-se com uma baixa identificação com a área profissionalizante.

Até esse momento o curso integrado agropecuária é o que se mostra mais alinhado a política pública, pois além de ter um quantitativo maior de alunos interessados em atuar como técnicos de nível médio de sua área de formação é também o curso em que os alunos possivelmente verticalizarão os estudos ao ingressar no ensino superior, aprimorando os conhecimentos técnicos já estudados, satisfazendo então o itinerário formativo da política pública.

Em sentido oposto ao curso de agropecuária, estão os alunos do curso de informática, não se mostrando interessados na atuação como técnico de informática e tampouco em prosseguir em estudos superiores na área.

Como se pode notar, no curso de meio ambiente grande parte (48\%) está indecisa. Refletimos que é natural, pois só existe $1^{\circ}$ e $2^{\circ}$ anos, e, portanto, ainda estão amadurecendo suas expectativas, talvez por ainda não começarem a fazer o estágio supervisionado não tenham conhecimento mais maduro sobre a profissão. Resolvemos então, fazer uma tabulação cruzada da mesma questão somente com os alunos dos $3^{\circ}$ anos de Informática e Agropecuária:

Gráfico 11 Desejo de Fazer Curso Superior na Área de Formação - $3^{\circ}$ anos

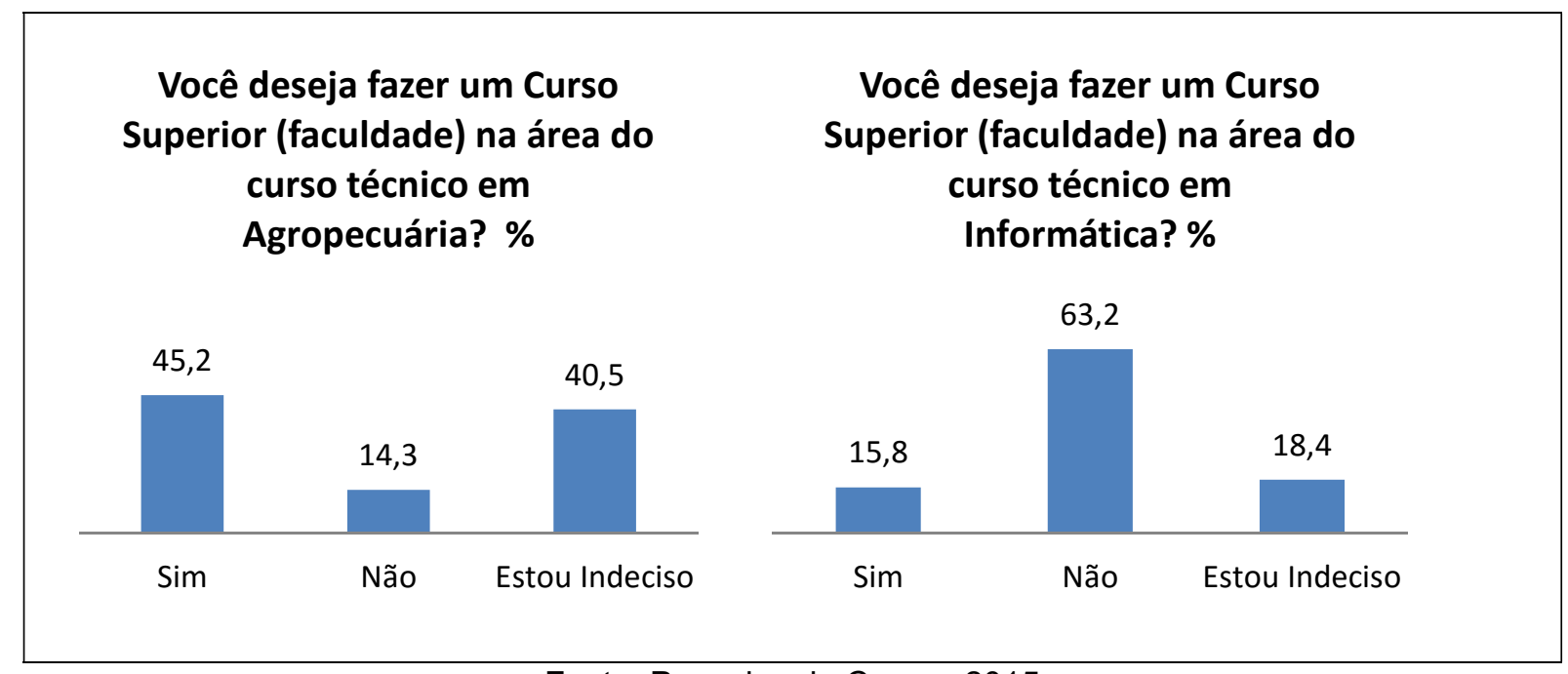

Fonte: Pesquisa de Campo 2015 
Como se vê, houve pouca alteração no curso de agropecuária confirmando um maior alinhamento com a política pública, mas em informática o percentual de indecisos diminui ao mesmo tempo em que o percentual "Não" (Não desejam continuar na área) aumentou consideravelmente $(14,6 \%)$ totalizando $63,2 \%$, ficando claro o baixo aproveitamento da habilitação profissional e todo o investimento nela aplicado.

Fatalmente os discentes reproduzirão resultados próximos aos extraídos na pesquisa de egressos realizados pelo IFNMG (aberto a todo o campi). O banco de dados de egressos do IFNMG não identifica exatamente o curso integrado, portanto não há como saber se ele é egresso de Agropecuária, Informática ou Meio Ambiente com exatidão, e também não registra o campus em que o egresso se formou, mas muito provavelmente grande parte dos dados se refere ao campus Januária ou campus Salinas, por ser os dois campus com maior tempo de atividade e quantidade de alunos.

Ao extrairmos, através do SPSS, as informações sobre o caminho realizado pelos alunos após concluírem o ensino integrado no IFNMG, vemos que os resultados também indicam pouco direcionamento ao mercado de trabalho. A pesquisa de egressos do IFNMG obteve 133 respondentes na modalidade Técnico Integrado, desse total $63(47 \%)$ disseram estar trabalhando, desses 63 apenas $11(17 \%)$ estão totalmente na área de formação e 18 (28\%) parcialmente.

Em relação à verticalização proporcionada pelo ensino integrado desses 133 egressos 104 ingressaram no ensino superior, sendo $46,2 \%$ em área fortemente relacionada com a área do curso técnico integrado cursado. 
Gráfico 12 Egressos Itinerário Formativo

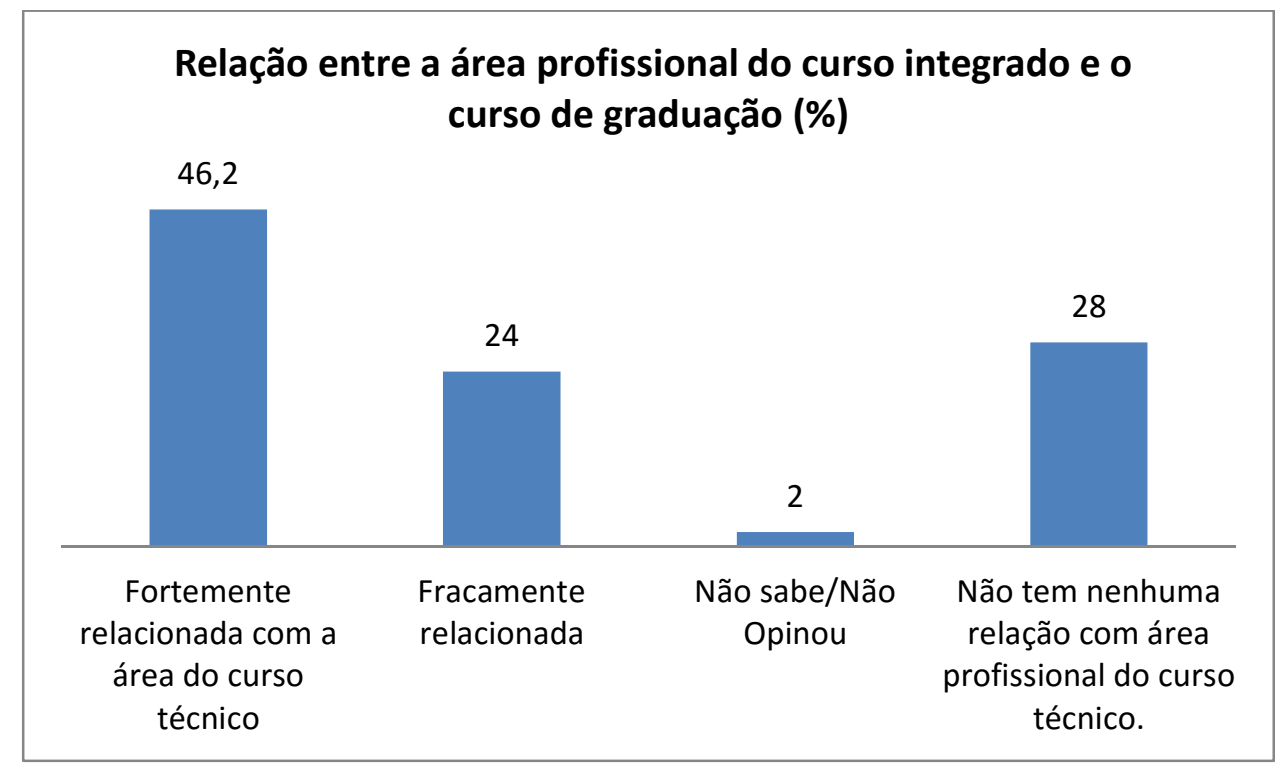

Fonte: Pesquisa de Campo 2015 - Base de Dados Egressos IFNMG

Vimos até esse momento que no curso integrado agropecuária os discentes estão bem mais alinhados aos objetivos da política pública do que os alunos de informática; tanto em relação ao interesse em atuar como técnicos de nível médio de sua área de formação quanto em continuar os estudos em nível superior na área de formação técnica.

Esses dois cursos possuem uma diferença significativa no modo como a modalidade integrada é implementada na Instituição, enquanto no curso de agropecuária o estágio supervisionado é obrigatório no curso de Informática é opcional, de livre escolha do aluno entre fazer ou não fazer.

Como vimos no primeiro capítulo o TCU (Tribunal de Contas da União) realizou uma auditoria nos Institutos Federais e ressaltou a importância das ações de inserção profissional pelos Institutos Federais destacando o estágio supervisionado, e que a proporção de alunos dos Institutos Federais com acesso a estágio ainda era baixa.

Outro importante estudo visto no primeiro capítulo, que também ressalta a importância do estágio supervisionado e que constatou deficiências no estágio supervisionado, foi a pesquisa do CNE/UNESCO (s.d.) onde foi observado que o ato educativo proporcionado pelo estágio supervisionado foi reduzido a ato burocrático. 
Portanto, na seção a seguir, analisaremos os resultados trazidos pelo componente curricular estágio supervisionado em cursos onde sua realização é obrigatória e opcional. Uma pergunta guia para a próxima seção poderia ser: Qual a influência do estágio supervisionado na formação profissional?

\section{Quanto ao Estágio Supervisionado}

Nessa seção do questionário sobre o estágio supervisionado, como informado na metodologia, as perguntas eram filtradas dependendo das respostas dos alunos, pois, por exemplo, não faz sentido perguntar ao aluno de informática que opta em não fazer o estágio (e muitas vezes não faz questão de saber do que se trata e como funciona) como é o ambiente disponibilizado pela empresa. O mesmo para Meio Ambiente, uma vez que é um curso novo e o estágio só se inicia a partir do segundo ano, sendo que a turma de segundo ano iniciou nesse $1^{\circ}$ semestre de 2015.

Portanto, a primeira pergunta no intuito de filtrar os respondentes que tinham conhecimento da atividade foi: "Você sabe o que é Estágio Supervisionado? "

\begin{tabular}{|c|c|c|}
\hline \multicolumn{3}{|c|}{$\begin{array}{c}\text { Você sabe o que é Estágio } \\
\text { Supervisionado? }\end{array}$} \\
\hline & Sim & Não \\
\hline Agropecuária & $82(45,6 \%)$ & $97(53,9 \%)$ \\
\hline Informática & $40(28,6 \%)$ & $93(66,4 \%)$ \\
\hline Meio Ambiente & $39(42,9 \%)$ & $46(50,5 \%)$ \\
\hline
\end{tabular}

Por se tratar de uma Instituição que tem como obrigação a Profissionalização esperávamos que os alunos tivessem o esclarecimento básico do que é o Estágio Supervisionado, mas os resultados dessa primeira questão surpreenderam negativamente, pois para os três cursos sobressaiu o desconhecimento da atividade. 
O resultado do curso técnico em agropecuária foi o que mais surpreendeu, devido à obrigatoriedade do estágio supervisionado no curso e também por ser o mais antigo da Instituição, como descrito no histórico da Instituição neste documento, esperava-se que os alunos responderiam "sim" em maior proporção, o que não ocorreu. Então fomos cruzar os dados da pergunta com o ano cursado do discente para sabermos mais sobre o ocorrido com o curso de agropecuária, e obtivemos:

\begin{tabular}{|c|c|c|c|}
\hline & & Sim & Não \\
\hline \multirow{4}{*}{ Ano Cursado } & $1^{\circ}$ & $21(11,7 \%)$ & $68(38 \%)$ \\
\hline & $2^{\circ}$ & $24(13,4 \%)$ & $24(13,4 \%)$ \\
\hline & $3^{\circ}$ & $37(20,7 \%)$ & $5(2,8 \%)$ \\
\hline & Total & $82(45,8 \%)$ & $97(54,2 \%)$ \\
\hline
\end{tabular}

Observando a tabulação cruzada acima se percebe que os alunos começam a tomar conhecimento sobre o estágio supervisionado à medida que vai se aproximando o término do curso, pois no $1^{\circ}$ ano apenas $24 \%$ sabem o que é estágio supervisionado, no segundo $50 \%$ e no terceiro $88 \%$. Parece-nos que não existe uma política eficiente de informação acerca do componente curricular, o ideal seria que todo discente ao ingressar, e até mesmo antes, na divulgação dos cursos da instituição, tenha bem esclarecido do que se trata a atividade estágio supervisionado e sua importância para o ensino integrado.

Ainda que essa grande quantidade de alunos não saiba o significado do termo "estágio supervisionado", eles reconhecem a importância deste componente curricular ao afirmar que acreditam que se eles colocassem em prática no ambiente de trabalho, aquilo que eles aprendem no seu curso do IFNMG, isto o ajudaria a entender melhor os conteúdos das disciplinas e também a the formar melhor para o mercado de trabalho. Vejamos a pergunta que foi feita e os resultados obtidos para os alunos que não conheciam o termo "estágio supervisionado" na tabela 6. 
Tabela 6 Opinião dos Discentes que não conhecem o termo estágio supervisionado

Você acredita que se você colocasse em prática no ambiente de trabalho, aquilo que você aprende aqui no seu Curso do IFNMG, isto o ajudaria a entender melhor os conteúdos das disciplinas e também a lhe formar melhor para o mercado de trabalho?

\begin{tabular}{lccc} 
& Sim & Não & Não Sei Opinar \\
\hline Informática & $63(67 \%)$ & $5(5 \%)$ & $25(26 \%)$ \\
Meio Ambiente & $39(84,8 \%)$ & $0(0 \%)$ & $7(15,2 \%)$ \\
Agropecuária & $82(84,5 \%)$ & $2(2,10 \%)$ & $13(13,40 \%)$ \\
\hline
\end{tabular}

O resultado acima mostra que os alunos são conscientes da importância em se integrar a teoria com a prática, tenham eles conhecimento do que é estágio supervisionado ou não, mas os resultados da questões anterior mostra que a Instituição não está aproveitando essa consciência do aluno para valorizar o componente estágio supervisionado, haja vista a ineficiente divulgação, os resultados da questão a seguir evidencia ainda mais essa ineficiência em esclarecer ao aluno o assunto estágio supervisionado.

O resultado da questão "O IFNMG the informou ou the deu acesso a algum documento explicando o que é o Estágio Supervisionado e como funciona? ", confirma o pouco esclarecimento que a Instituição dá aos discentes sobre o estágio, pois nela obtivemos:

Tabela 7 Divulgação do Estágio Supervisionado

O IFNMG Ihe informou ou the deu acesso a algum documento explicando o que é o Estágio Supervisionado e como funciona?

\begin{tabular}{lll} 
& Sim & Não \\
\hline Agropecuária & $75(41,9 \%)$ & $104(58,1 \%)$ \\
Informática & $13(9,8 \%)$ & $120(90,2 \%)$ \\
Meio Ambiente & $19(22,4 \%)$ & $66(77,6 \%)$ \\
\hline
\end{tabular}


Percebe-se que mesmo para os cursos onde o estágio é obrigatório a grande maioria indicou que a Instituição não informou ou deu acesso a algum documento explicando o que é o Estágio Supervisionado e como ele funciona, mas, o mais preocupante é quanto aos alunos de informática onde $90,2 \%$ responderam "não", isso nos indica que é necessário a instituição reavaliar o modo como ela promove o eixo formação para o trabalho da política pública em especial o estágio supervisionado.

O fato de a Instituição escolher a modalidade de estágio supervisionado de categoria "não obrigatório" (opcional) para o curso de informática, não justifica isenção da sua responsabilidade de esclarecimentos sobre a atividade.

Como já discutido no primeiro capítulo a pesquisa realizada pelo CNE/UNESCO (s.d.) evidenciou deficiências no estágio obrigatório em diversas Instituições e apontou preocupação com o "estágio não obrigatório", diante dos resultados acima vemos razão em sua preocupação.

Para os alunos que sabiam o que é estágio supervisionado foi feita a pergunta "Você vai fazer (ou está fazendo) Estágio Supervisionado: " 62,2\% dos discentes (51 alunos) de agropecuária e 48,7\% (19 alunos) de Meio Ambiente informaram fazer para melhor atuar como técnico de sua habilitação profissional, enquanto que $37,8 \%$ (31 alunos) de agropecuária e 51,3\% meio ambiente (20 alunos) disseram fazer porque é obrigatório no curso.

Lembramos e atentamos o leitor que a turma de meio ambiente inicia os estágios esse ano, talvez o desconhecimento da atividade explique 0 alto desinteresse.

Em Informática como o estágio é opcional a pergunta foi "Você pretende fazer estágio supervisionado? ", dos 40 alunos que responderam que sabiam o que era estágio supervisionado, 21 responderam "sim", pretendem fazer o estágio supervisionado; dos 19 restantes que responderam "não",10 informaram que não têm interesse em trabalhar como técnico em Informática, 2 pretendem Trabalhar como técnico em Informática mas preferem não fazer e 7 escolheram a opção "outros".

Pensamos que se a Instituição não der o devido incentivo e orientação a esses 21 alunos de informática, que pretendem fazer o estágio supervisionado, fatalmente eles não o farão, pois atualmente nenhum aluno de informática do $3^{\circ}$ ano está fazendo 
estágio supervisionado, e como podemos ver abaixo à medida que vai se aproximando do final do curso o interesse em trabalhar na área de informática vai diminuindo.

Tabela 8 Desejo de Trabalhar na Área Técnica Quando Ingressou por Ano - Informática

\begin{tabular}{ccccccc}
\hline & Muito Alto & Alto & Médio & \multirow{2}{*}{ Baixo } & \multirow{2}{*}{ Muito Baixo } & Irrelevante \\
\hline $1^{\circ}$ Ano & $10(7,4 \%)$ & $17(12,6)$ & $16(11,9 \%)$ & $9(6,7 \%)$ & $3(2,2 \%)$ & $0(0 \%)$ \\
$2^{\circ}$ Ano & $4(3 \%)$ & $11(8,1 \%)$ & $15(11,1 \%)$ & $1(0,7 \%)$ & $7(5,2 \%)$ & $5(3,7 \%)$ \\
$3^{\circ}$ Ano & $5(3,7 \%)$ & $2(1,5 \%)$ & $8(5,9 \%)$ & $10(7,4 \%)$ & $6(4,4 \%)$ & $6(4,4 \%)$ \\
Total & $19(14,1 \%)$ & $30(22,2 \%)$ & $39(28,9 \%)$ & $20(14,8 \%)$ & $16(11,9 \%)$ & $11(8,1 \%)$ \\
\hline
\end{tabular}

Fonte: Pesquisa de Campo 2015

Tabela 9 Desejo Atual de Trabalhar na Área Técnica por Ano - Informática

\begin{tabular}{|c|c|c|c|c|c|c|}
\hline & Muito Alto & Alto & Méc & $\mathrm{Ba}$ & Muito Baixo & Irrelevante \\
\hline $1^{\circ}$ Ano & & ) & 17( & & & \\
\hline $2^{\circ}$ Ano & $2(1$, & $9 \%)$ & aic & $\%)$ & 14( & $5(3,7 \%)$ \\
\hline $3^{\circ}$ Ano & $1(0,7$ & 4 & 4( & 6) & & $\%)$ \\
\hline Total & $11(8,1 \%)$ & $29(21,5 \%)$ & $30(22,2 \%)$ & $23(17 \%)$ & $29(21,5 \%)$ & $13(9,6 \%)$ \\
\hline
\end{tabular}

Fonte: Pesquisa de Campo 2015

Nas tabelas anteriores (8 e 9) os índices "Muito Alto", "Alto" e "Médio" de desejo dos discentes de Informática em trabalharem na área técnica sofreram baixas alimentando os indicativos "Baixo", "Muito Baixo" e "Irrelevante" com o passar do tempo.

Para o curso de agropecuária o comportamento foi inverso ao curso de informática, ou seja, à medida que foi se aproximando do final do curso o desejo em trabalhar na área foi aumentando.

Na tabela do curso agropecuária abaixo, vemos ganhos acentuados no indicativo "Muito Alto", a partir do $2^{\circ}$ ano, período em que o estágio supervisionado pode começar a ser desenvolvido pelo aluno, nos parece que o estágio supervisionado possa estar auxiliando o discente a descobrir, a despertar sua vocação profissional, alimentando também o seu interesse pela área profissional. Como Lima e 
Vasconcelos (2006, p.28) afirmam "o estágio é antes de tudo uma antecipação da prática da profissão", o Parecer CNE/CEB (2003, p.43) também aponta para esse entendimento ao declarar que a "identificação mais clara das opções para a escolha profissional" e a "organização" do "perfil de profissionalização" do discente é um benefício garantido pela atividade de estágio.

Tabela 10 Desejo de Trabalhar na Área Técnica Quando Ingressou - Agropecuária

\begin{tabular}{ccccccc}
\hline & Muito Alto & Alto & Médio & Baixo & Muito Baixo & Irrelevante \\
\hline $1^{\circ}$ Ano & $16(8,9 \%)$ & $21(11,7 \%)$ & $30(16,8 \%)$ & $11(6,1 \%)$ & $6(3,4 \%)$ & $5(2,8 \%)$ \\
$2^{\circ}$ Ano & $10(5,6 \%)$ & $13(7,3 \%)$ & $14(7,8 \%)$ & $6(3,4 \%)$ & $2(1,1 \%)$ & $3(1,7 \%)$ \\
$3^{\circ}$ Ano & $8(4,5 \%)$ & $7(3,9 \%)$ & $13(7,3 \%)$ & $9(5 \%)$ & $4(2,2 \%)$ & $1(0,6 \%)$ \\
Total & $34(19,0 \%)$ & $41(22,9 \%)$ & $57(31,8 \%)$ & $57(31,8 \%)$ & $12(6,7 \%)$ & $9(5 \%)$ \\
\hline
\end{tabular}

Fonte: Pesquisa de Campo 2015

Tabela 11 Desejo de Trabalhar na Área Técnica Atualmente - Agropecuária

\begin{tabular}{|c|c|c|c|c|c|c|}
\hline & Muito Alto & Alto & Médio & Baixo & Muito Baixo & Irrelevante \\
\hline $1^{\circ} \mathrm{Ano}$ & $19(10,6 \%)$ & $29(16,2 \%)$ & $29(16,2 \%)$ & $6(3,4 \%)$ & $6(3,4 \%)$ & $0(0 \%)$ \\
\hline $2^{\circ}$ Ano & $18(10,1 \%)$ & $8(4,5 \%)$ & $15(8,4 \%)$ & $3(1,7 \%)$ & $2(1,1 \%)$ & $2(1,1 \%)$ \\
\hline $3^{\circ}$ Ano & $16(8,9 \%)$ & $10(5,6 \%)$ & $13(7,3 \%)$ & $3(1,7 \%)$ & $0(0 \%)$ & $0(0 \%)$ \\
\hline Total & $53(29,6 \%)$ & $47(26,3 \%)$ & $57(31,8 \%)$ & $12(6,7 \%)$ & $8(4,5 \%)$ & $2(1,1 \%)$ \\
\hline
\end{tabular}

A partir desse momento a análise será feita mais em relação ao Curso Técnico Integrado Agropecuária, pois são questões que necessitam que o aluno esteja realizando o estágio supervisionado.

No curso de agropecuária 33 alunos informaram estar realizando o estágio supervisionado ou terminado a carga horária. Estão distribuídos com a seguinte situação:

Tabela 12 Carga Horária Realizada

\begin{tabular}{cc}
\hline Situação & Quantitativo \\
\hline Já terminaram & $20(60,6 \%)$ \\
De 100 a 160 Horas & $8(24,2 \%)$ \\
Entre 8 e 49 Horas & $5(15,2 \%)$ \\
\hline \multicolumn{2}{c}{ Fonte: Pesquisa de Campo }
\end{tabular}


O curso de agropecuária pode nos informar como é operacionalizado o estágio supervisionado e também nos fornecer impressões das contribuições que esse componente curricular pode propiciar aos discentes da educação profissional integrada ao ensino médio.

As perguntas "O acompanhamento e a supervisão realizados pela empresa (a fornecedora de estágio) durante o estágio estão sendo: " e "O acompanhamento e a supervisão realizados pelo IFNMG-Januária durante o estágio foram/estão sendo: " visavam verificar a assistência que é dada ao discente no estágio, tanto pela concedente quanto pela instituição. Essas duas perguntas só estavam disponíveis aos alunos que tinham no mínimo 8 horas de estágio, os que tinham entre 100 a 160 horas e os que já haviam terminado toda a carga horária do estágio supervisionado.

Gráfico 13 Acompanhamento do IFNMG x Acompanhamento da Concedente

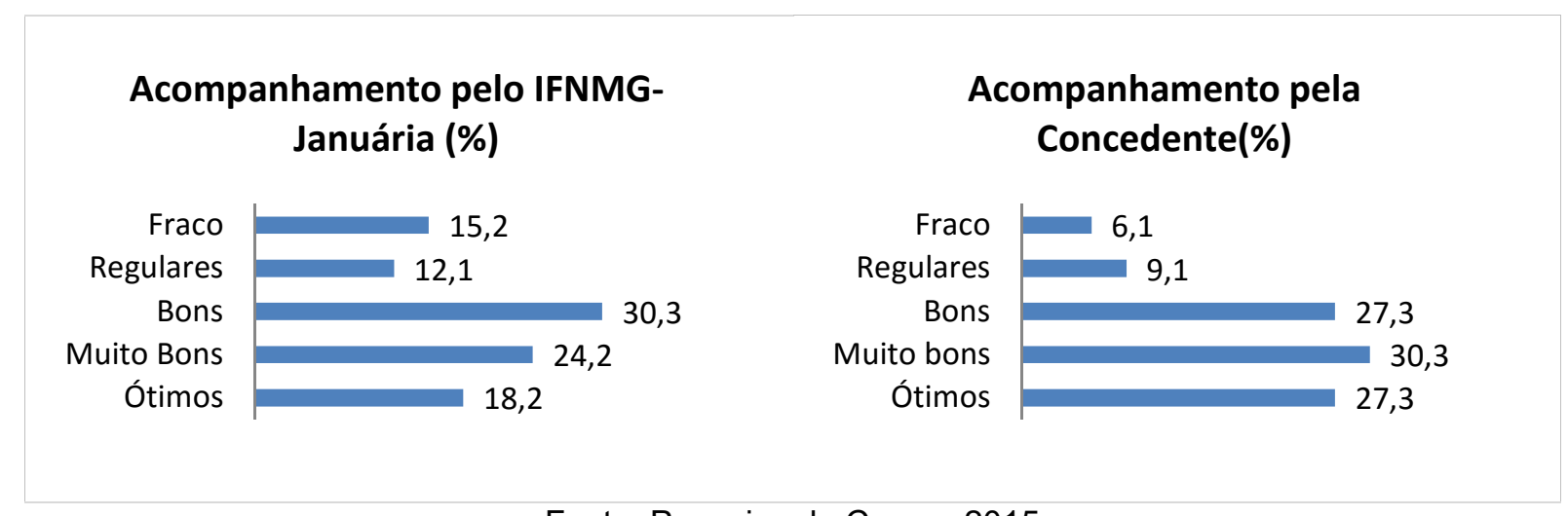

Fonte: Pesquisa de Campo 2015

Vemos que a concedente melhor acompanha e supervisiona o discente, embora o acompanhamento pela Instituição também se vê bons resultados. Especificando a questão para a responsabilidade que o professor orientador tem na Lei 11.788 em supervisionar o estágio fizemos a seguinte pergunta: "Durante o seu estágio supervisionado o professor da área: " 
Gráfico 14 Acompanhamento pelo Professor Orientador

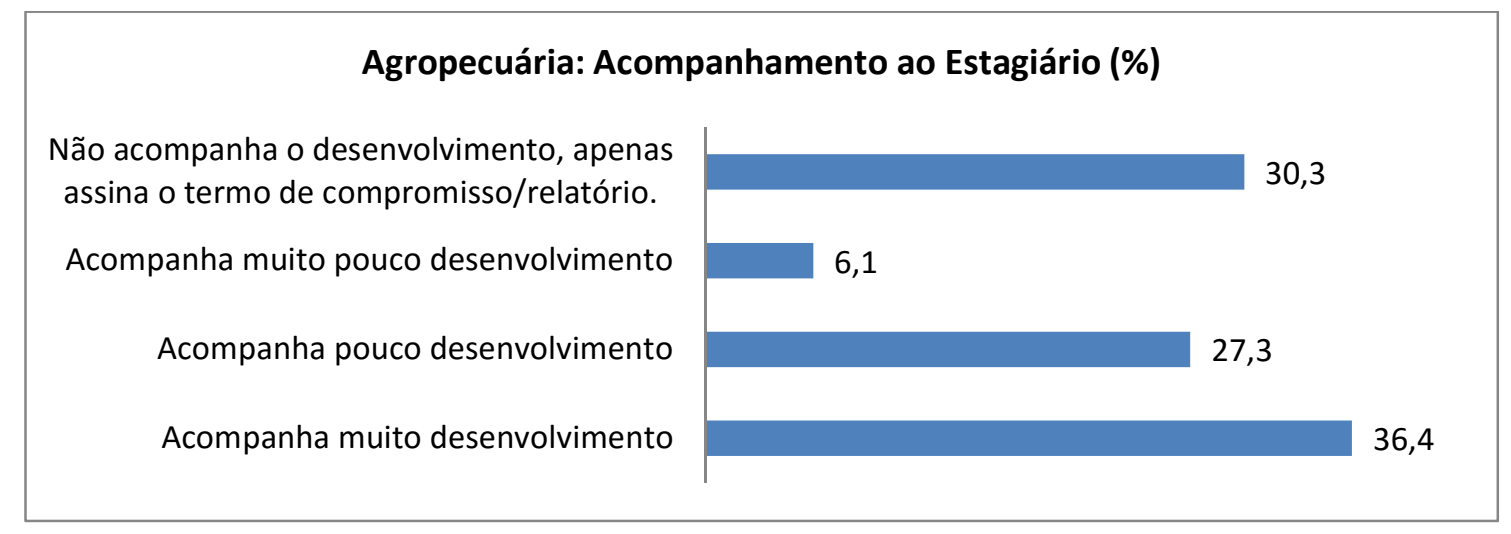

Fonte: Pesquisa de Campo 2015

Nesse ponto específico, vemos uma deficiência dessa importante obrigação da Instituição na supervisão do discente. A Lei $11.788 / 2008$ no $\S 1^{\circ}$ do Art. $3^{\circ}$ define que o estágio deve ter acompanhamento efetivo pelo professor orientador da instituição de ensino e pelo supervisor da parte concedente, condicionando a comprovação do acompanhamento por vistos nos relatórios e por menção de aprovação final:

$\S 1$ 10 O estágio, como ato educativo escolar supervisionado, deverá ter acompanhamento efetivo pelo professor orientador da instituição de ensino e por supervisor da parte concedente, comprovado por vistos nos relatórios referidos no inciso IV do caput do art. 7으 desta Lei e por menção de aprovação final. (Lei 11.788/2008)

Vemos que uma quantidade significativa de alunos 63,6\% (21 alunos) indicaram baixo ou nenhum acompanhamento ao estagiário, desses $63,6 \% ; 30,3 \%$ informaram que o acompanhamento do professor se reduziu à apenas assinar o relatório de estágio, corroborando com a afirmação do CNE/UNESCO (s.d.) quando afirmou que o ato educativo havia se transformado em ato burocrático.

Em relação à sintonia entre a grade curricular e o campo de trabalho observamos bons resultados. Na pergunta "As aulas práticas do curso técnico em relação à realidade prática apresentada pelo estágio foi: " 84,8\% julgaram ser "Bem Parecidos" e "Parecidos"; e quanto à relação das disciplinas de modo geral (teóricas e práticas) $81,8 \%$ informaram que é "Muito Relacionado" com o estágio supervisionado. 
Ainda visando conhecer melhor a integração do curso profissionalizante com o mercado de trabalho, outras questões também forneceram bons indicativos; 93,9\% dos estagiários informaram que para a realização das tarefas do estágio os conhecimentos obtidos nas disciplinas do curso foram "importantes" ou "muito importantes" (39,4\% e 54,5\% respectivamente), essas informações definitivamente conferem e vão de encontro com o propósito do estágio supervisionado em proporcionar o Ato Educativo e sua adequação a Lei.

Em geral, temos então, um bom aproveitamento do estágio supervisionado em sua tarefa de promover o ato educativo, porém, $24 \%$ dos estagiários apontaram desvio de funções, o que pode caracterizar vínculo empregatício conforme descreve a Lei 11.788/08:

Art. 3응 $\mathrm{O}$ estágio, tanto na hipótese do $\S 1^{\circ}$ do art. $2^{\circ}$ desta Lei quanto na prevista no $\S 2^{\circ}$ do mesmo dispositivo, não cria vínculo empregatício de qualquer natureza, observados os seguintes requisitos: [...]

III - compatibilidade entre as atividades desenvolvidas no estágio e aquelas previstas no termo de compromisso.

\section{$[\ldots]$}

Art. 5o As instituições de ensino e as partes cedentes de estágio podem, a seu critério, recorrer a serviços de agentes de integração públicos e privados, mediante condições acordadas em instrumento jurídico apropriado, devendo ser observada, no caso de contratação com recursos públicos, a legislação que estabelece as normas gerais de licitação.

§ 3o Os agentes de integração serão responsabilizados civilmente se indicarem estagiários para a realização de atividades não compatíveis com a programação curricular estabelecida para cada curso, assim como estagiários matriculados em cursos ou instituições para as quais não há previsão de estágio curricular. (Lei 11.788)

Portanto soa muitíssimo importante o diálogo contínuo com os estagiários a fim de perceber as incompatibilidades com o termo de compromisso, e caso seja constatado desvios de funções, medidas deverão ser tomadas para que se recupere $o$ ato educativo.

A "baixa ou nenhuma remuneração" foi apontada por $61 \%$ dos estagiários. O Ministério do Trabalho e Emprego (MTE) elaborou uma Cartilha que visa dar esclarecimentos sobre a nova Lei do Estágio (11.788/2008) para orientar Estudantes, Empresas, Profissionais Liberais e Instituições de Ensino, públicas e particulares, 
essa cartilha informa o seguinte:

44. Quando o estágio deve ser obrigatoriamente remunerado (concessão de bolsa ou outra forma de contraprestação)?

No caso do estágio não obrigatório é compulsória a concessão de bolsa ou outra forma de contraprestação que venha a ser acordada no Termo de Compromisso do Estágio. Somente no caso de estágio obrigatório é que a concessão de bolsa ou outra forma de contraprestação é facultativa (art. 12 da Lei 11.788/2008).

Sendo assim, quanto à remuneração, poderia ser dada a oportunidade de o aluno escolher também pelo estágio de categoria "não obrigatório", incluindo essa modalidade no plano de curso, sendo então obrigatório para os alunos que assim escolhessem, dando-os a oportunidade de serem remunerados quando houvesse a possibilidade em alguma concedente. Em relação à obrigação de realiza-lo mesmo sendo de categoria "não obrigatório" o PARECER CNE/CEB 35/2003 descreve:

Estágio profissional não obrigatório, mas incluído no respectivo plano de curso, o que o torna obrigatório para os seus alunos, mantendo coerência com o perfil profissional de conclusão do curso; (PARECER CNE/CEB 35/2003, p.43)

Embora os alunos tenham percebido uma forte relação das disciplinas com a atividade de estágio supervisionado, que como dito é valioso, 55\% dos estagiários de agropecuária apontaram que as atividades ficaram restritas a pequena parte do currículo, refinando a informação somente com os estagiários do terceiro ano com mais de 100 horas de estágio (ou seja, próximos de completarem a carga horária total) temos ainda $53 \%$ que apontaram restrição a pequena parte do currículo.

A Resolução CNE/CEB Nº 1, DE 21 de Janeiro de 2004prevê que: 
$\S 3^{\circ} \bigcirc$ estágio deve ser realizado ao longo do curso, permeando $o$ desenvolvimento dos diversos componentes curriculares e não deve ser etapa desvinculada do currículo. (RESOLUÇÃO CNE/CEB No 1, DE 21 DE JANEIRO DE 2004, grifo nosso)

Niskier e Souza (2006) também defendem o amplo envolvimento do estágio com o curso:

\begin{abstract}
O estágio não substitui a aprendizagem escolar. Sua função é a de suplementar o conhecimento adquirido em sala de aula, vivenciando, na prática, o saber teórico que advém do conjunto de disciplinas do currículo de curso. [...]. Aqui surge uma primeira questão de interesse: o estágio deve corresponder sempre ao conteúdo de determinada disciplina curricular? É claro que não: sua função é holística e diz respeito ao conjunto de conhecimentos do curso como um todo. [...] A finalidade do estágio, pois, está na sua função auxiliar de inserir um aluno nas realidades extra-escolares do trabalho. Em razão dessa natureza pragmática não integra o estágio a estrita curricularidade deste ou daquele curso, devendo antes ser entendido como uma extensão do currículo e sua completação formativa, na capacitação de alunos para o trabalho (SOUZA, NISKIER, 2006, p. 125-126, grifo nosso).
\end{abstract}

Porém, com apenas, 150 horas de estágio no curso integrado, era de se esperar tal resultado informado pelos alunos, pois com uma carga horária tão curta fica impossível permear com satisfação os diversos componentes curriculares, afinal de contas, cursos Técnicos Integrados têm no mínimo 3.000 horas, com diversas disciplinas tanto propedêuticas quanto técnicas.

Na pergunta "Você acredita que a carga horaria de 150 ou 160 horas do estágio supervisionado é suficiente para lhe preparar para o Mercado de Trabalho como técnico em Agropecuária? ". Realizando uma tabulação cruzada a fim de verificar a percepção dos alunos mais experientes, ou seja, os estagiários do $3^{\circ}$ ano que já estavam por terminar ou terminado o estágio supervisionado, tendo então no mínimo 100 horas completas, obtivemos 28 alunos, desses, 16 estagiários (57\%) julgaram que a carga horária do estágio supervisionado não é suficiente.

A informação acima evidencia claramente que a baixa carga horária do estágio supervisionado dificultou a contextualização curricular como prevê a natureza de concepção do estágio supervisionado e requer a Lei de Estágio 11.788/08, 
consequentemente também se limitou o ato Educativo como um todo, atentando que a Instituição precisa repensar a carga horária do estágio supervisionado.

O Parecer CNE/CP n² 28, de 2 de outubro de 2001 que dá nova redação ao Parecer CNE/CP 21/2001, embora trate da duração e a carga horária dos cursos de Formação de Professores, traz essa pertinente observação acerca do estágio supervisionado.

É fundamental que haja tempo e espaço para a prática, como componente curricular, desde o início do curso e que haja uma supervisão da instituição formadora como forma de apoio até mesmo à vista de uma avaliação de qualidade. (Parecer $\mathrm{CNE} / \mathrm{CP} \mathrm{n}^{\circ} 28$, de 2 de outubro de 2001)

Porém o aumento da carga horária do estágio supervisionado certamente aumentaria a duração do curso para mais de três anos. Será que os discentes do IFNMG-Januária teriam interesse em cursar o ensino integrado caso ele possuísse uma duração maior que três anos ${ }^{10}$ ? Para descobrir a resposta, fizemos a seguinte pergunta a todos os discentes: "Se o curso Integrado do IFNMG - Januária tivesse duração de 4 ANOS ou 3 ANOS e MEIO, com AULAS SOMENTE EM UM ÚNICO TURNO, ou seja, aulas SOMENTE PELA MANHÃ ou AULAS SOMENTE A TARDE. Você: ". Obtivemos:

10 O Instituto Federal de Educação, Ciência e Tecnologia de Mato Grosso do Sul - IFMS, por exemplo, possui cursos integrados de três anos e meio num único turno e com estágio supervisionado, existem vários outros Institutos que adotaram três anos e meio ou quatro anos. 
Gráfico 15 Interesse em Cursar o Integrado com Mais de 3 Anos

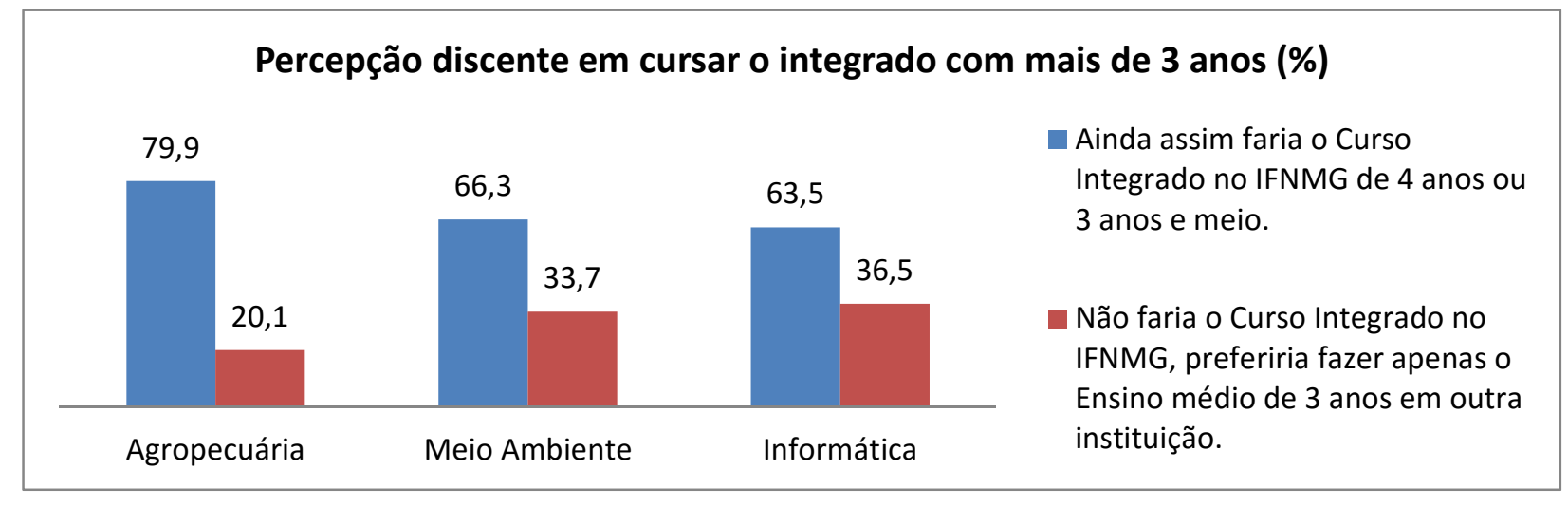

Fonte: Pesquisa de Campo 2015

Vemos que a maioria dos discentes, principalmente os de agropecuária, ainda fariam o curso técnico integrado no IFNMG-Januária caso a duração fosse estendida para mais de três anos, viabilizando a implementação de um estágio supervisionado com maior carga horária que poderia melhor comportar e desenvolver tudo o que esse componente curricular visa oferecer, e assim atendendo melhor a definição dada pela RESOLUÇÃO CNE/CEB № 1, DE 21 DE JANEIRO DE 2004, ou seja, permeando com melhor qualidade o desenvolvimento dos diversos componentes curriculares ao longo do curso.

O diálogo com os estagiários relatando suas experiências é importante para saber se não há desvio de funções como descrito anteriormente, mas também é extremamente relevante para se conhecer o próprio currículo do curso, atualizando-o quando necessário. A pergunta "Houve a necessidade de aprendizado de outros conhecimentos teóricos/práticos não abordados no seu curso?" feita para os estagiários que já completaram toda a carga horária ou estão finalizando, evidenciou a necessidade de discussão acerca de novos conteúdos que poderiam ser incluídos no curso, ver tabela 13. 
Tabela 13 Necessidade de Aprendizado de Outros Conhecimentos

Houve a necessidade de aprendizado de outros conhecimentos teóricos/práticos não abordados no seu curso?

\begin{tabular}{cccccc}
\hline Estágios & Sim, Muito & Sim, Alguns & Sim, Pouco & $\begin{array}{c}\text { Não, } \\
\text { Nenhum }\end{array}$ & Total \\
$\begin{array}{c}\text { completos } \\
\text { ou }\end{array}$ & $6(21 \%)$ & $14(50 \%)$ & $5(18 \%)$ & $3(11 \%)$ & $28(100 \%)$ \\
finalizando & & & & & \\
\hline
\end{tabular}

Fonte: Pesquisa de Campo 2015

Como se observa, 25 estagiários (89\%) que já completaram ou estão completando a carga horária do estágio, informaram que houve necessidade de aprendizado de outros conhecimentos teóricos ou práticos não abordados no curso. A adequação sempre que necessária dos conteúdos das disciplinas com a área profissional impede que se perca a relação entre teoria e prática necessária na formação profissionalizante.

Pimenta e Lima (2004) nos atenta quanto à relação das disciplinas com o campo profissional e ainda lança questões para reflexão quando no desenvolvimento de um projeto de curso:

$\mathrm{Na}$ verdade, os currículos de formação têm-se constituído em um aglomerado de disciplinas, isoladas entre si, sem qualquer explicitação de seus nexos com a realidade que lhes deu origem. Assim, sequer pode-se denominá-las de teorias, pois constituem apenas saberes disciplinares, em cursos de formação que, em geral, estão completamente desvinculados do campo de atuação profissional dos futuros formandos. Neles, as disciplinas do currículo assumem quase total autonomia em relação ao campo de atuação dos profissionais e, especialmente, ao significado social, cultural, humano da ação desse profissional. O que significa ser profissional? Que profissional se quer formar? Qual a contribuição da área na construção da sociedade humana, de suas relações e de suas estruturas de poder e de dominação? Quais os nexos com o conhecimento científico produzido e em produção? São questões que, muitas vezes, não são consideradas nos programas das disciplinas, nos conteúdos, objetivos e métodos que desenvolvem. (PIMENTA; LIMA, 2004 p.33-34)

Esse descompasso que vem ocorrendo entre os conteúdos do curso e a realidade do mundo do trabalho poderia ficar evidenciado para a Instituição caso houvesse momentos em que os discentes pudessem compartilhar os conhecimentos 
vivenciados no estágio supervisionado. Para a pergunta "Existe um momento formalizado no IFNMG onde os alunos estagiários compartilham os conhecimentos vivenciados no estágio supervisionado? "; 75,8\% responderam que não existe.

Apesar das deficiências constatadas na atividade do estágio supervisionado 92,7\% dos estagiários responderam que acreditam que o Estágio Supervisionado é importante para sua atuação como profissional.

No gráfico abaixo vemos que apenas 3,7\% dos discentes não veem importância no estágio supervisionado.

Gráfico 16 Importância do Estágio para o Discente

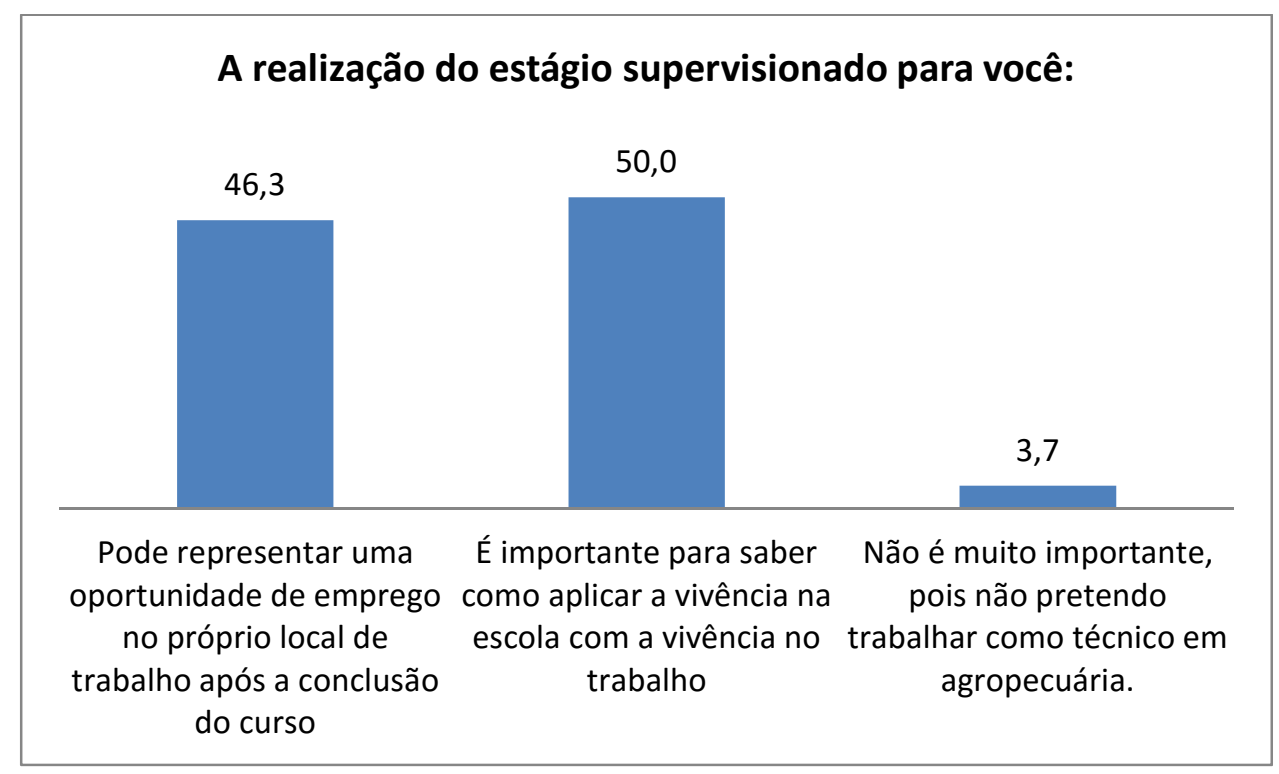

Fonte: Pesquisa de Campo 2015

Outros benefícios apontados pelos discentes, que ocorrem durante estágio supervisionado foram (Soma dos indicativos "Ótimo" e "Bom"):

- 75,8\%: Desenvolvimento de novas metodologias e/ou tecnologias

- 57,5\%: Uso de equipamentos tecnológicos modernos

- 93,9\%: Trabalho em Equipe

Vemos que o contato que o discente tem com o ambiente de trabalho real além da relação da teoria com a prática já vista, contribui também com o acesso a recursos e métodos que não estão presentes na Instituição de Ensino, o que é natural, porque 
o papel da concedente é de estender o aprendizado além da escola com recursos e métodos específicos do processo de produção.

É importante notar que 93,9\% dos estagiários apontaram a ocorrência do fator "Trabalho em Equipe" durante o estágio, oportunizando ao aluno o contato com a realidade social no qual a profissão está inserida enriquecendo a experiência do estagiário. Cavalcante e Vasconcelos (2006) denominam o produto das relações entre os indivíduos no ambiente de trabalho de "Cultura Organizacional" e ainda informa que durante esse momento "o aluno passa a conhecer sua profissão, principalmente pesquisando junto de pessoas que já tem prática nela" e dessa forma "o conhecimento Ihe será ampliado de forma incalculável". (CAVALCANTE; VASCONCELOS, 2006, p.52).

Corroborando com a importância do trabalho em equipe proporcionado pelo estágio supervisionado apontado pela pesquisa, Gonçalves e Costa Neto (2006, p.97) nos informam que "as teorias sobre a aprendizagem têm dado ênfase a importância das interações sociais entre as pessoas, destacando também a relevância da socialização do saber como forma de manifestação do princípio da alteridade".

Enfim, no intuito de contrastar o impacto do componente curricular estágio supervisionado na formação profissional nos grupos que fazem e os que não fazem estágio supervisionado (Agropecuária e Informática respectivamente), no gráfico abaixo apresentamos a percepção dos dois grupos de estudantes do $3^{\circ}$ ano quanto a sua segurança em estar preparados para o mercado de trabalho.

Gráfico 17 Percepção de Preparo Profissional

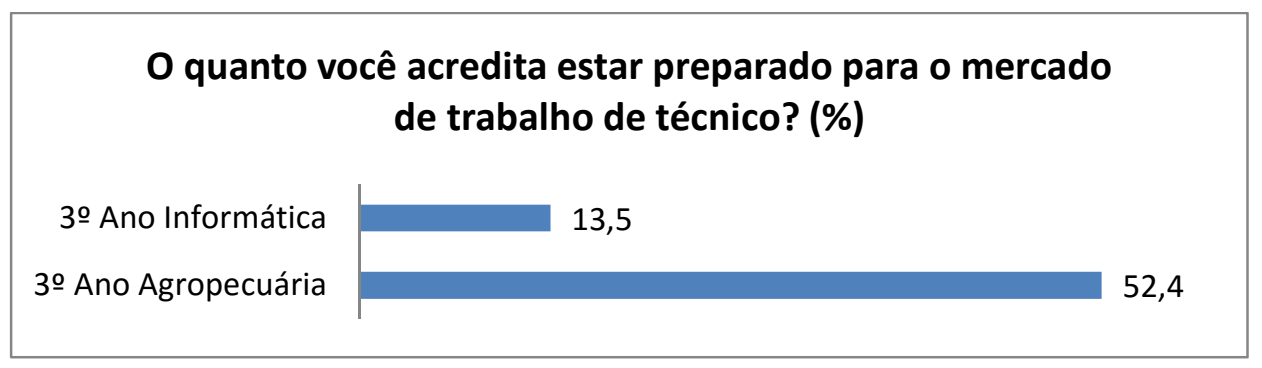

Fonte: Pesquisa de Campo 2015

O resultado dessa última pergunta definitivamente conferiu ao estágio supervisionado a importância com a qual a Lei e a Literatura sustentam sua 
importância, principalmente no ensino profissionalizante. Embora a atividade apresente algumas deficiências que devam ser sanadas, vemos que de fato, dentro dos limites como foi implementado, o estágio supervisionado promoveu, junto aos discentes que o realizam, o Ato Educativo que o fundamenta, isso nos faz pensar da experiência enriquecedora na formação integrada que os discentes de Informática não estão desfrutando.

\subsubsection{Análise da Fase Qualitativa}

Como informado na Metodologia essa fase da pesquisa visa entender melhor alguns resultados quantitativos que pensamos ser importantes aprofundar para melhor compreender o fenômeno pesquisado, trechos da entrevista transcrita foram codificados e apresentados em forma de tabela com a seguinte disposição:

1) Coluna Categoria e Subcategoria: agregam os dois principais temas da entrevista (Concepções Acerca do Instituto Federal e Caracterização do Estágio Supervisionado) e suas ramificações.

2) Coluna Unidade de Registo: Possui apenas as palavras chave ou frases que indicam o significado dos trechos de texto da Unidade de Contexto.

3) Unidade de Contexto: encontram-se os fragmentos de texto em tamanho suficiente capaz expressar o sentido apontado pela unidade de registro, contextualizando-a.

Para uma apresentação mais agradável do quadro de categorização resolvemos dividi-lo em dois, uma para cada Categoria. 


\section{Quadro de Categorização I}

\begin{tabular}{|c|c|c|c|}
\hline Categoria & Subcategoria & $\begin{array}{l}\text { Unidade de } \\
\text { Registro }\end{array}$ & Unidade de Contexto \\
\hline \multirow[t]{2}{*}{$\begin{array}{l}\text { Concepções } \\
\text { Acerca do } \\
\text { Instituto } \\
\text { Federal }\end{array}$} & $\begin{array}{l}\text { Propósito do Ensino } \\
\text { Integrado }\end{array}$ & $\begin{array}{l}\text { Habilitação } \\
\text { Profissional } \\
\text { Formação Integral }\end{array}$ & $\begin{array}{l}\text { "[...] o nosso aluno aqui ao final do } \\
\text { curso ele está habilitado como técnico } \\
\text { em determinada área [...] ele está } \\
\text { tendo acesso também ao a } \\
\text { conhecimento dos fenômenos, sejam } \\
\text { sociais, naturais que envolvem toda a } \\
\text { profissão. [...]". } \\
\text { "[...] é que o aluno além de ter a } \\
\text { formação do ensino médio comum, } \\
\text { eles saem do Instituto Federal com o } \\
\text { diploma de técnico em alguma área } \\
{[\ldots . .] \text {. }}\end{array}$ \\
\hline & $\begin{array}{l}\text { Percepção do } \\
\text { Desejo de } \\
\text { Formação do } \\
\text { Discente }\end{array}$ & $\begin{array}{l}\text { Qualidade do } \\
\text { Ensino Médio } \\
\text { Professores } \\
\text { Capacitados } \\
\text { Região Carente }\end{array}$ & $\begin{array}{l}\text { "eles [os Institutos Federais] estão } \\
\text { adentrando nos municípios mais } \\
\text { pobres, menores, as regiões" } \\
\text { "[...] única opção de uma escola de } \\
\text { ensino médio de qualidade." } \\
\text { "[...] referência de ensino médio é o } \\
\text { Instituto Federal." } \\
\text { "[...] professor de Matemática doutor } \\
\text { em Matemática, professor em Física, } \\
\text { doutor em Física ministrando aulas em } \\
\text { escolas públicas não é muito comum, } \\
\text { só é comum em Institutos Federais. " } \\
\text { "[...] a grande maioria vem procurando } \\
\text { o ensino médio de qualidade." }\end{array}$ \\
\hline
\end{tabular}

Categoria 1: Concepções Acerca do Instituto Federal

Subcategoria: Propósito do Ensino Integrado

Vimos no capítulo 01 que as instituições técnicas profissionalizantes se caracterizaram fortemente pelo ótimo desempenho no eixo prosseguimento de estudos, mas não se podendo dizer o mesmo quanto ao eixo formação para o trabalho, e que inclusive essa situação foi evidenciada no relatório do TCU.

Ante o exposto, entendeu-se oportuno conhecer dos docentes (que ocupam cargos que podem influenciar fortemente a política pública na Instituição) suas 
concepções sobre os objetivos dos Institutos Federais, haja vista as deficiências apresentadas no trato com o estágio supervisionado. Sendo assim, fizemos o seguinte questionamento: "O que diferencia os Institutos Federais que ofertam o ensino médio integrado das outras instituições que ofertam o ensino médio regular? ".

[...]o nosso aluno aqui ao final do curso ele está habilitado como técnico em determinada área. Mais o grande diferencial ai, eu entendo que está em todo o conjunto da formação, todo o processo de formação que o aluno passa aqui na instituição [...] é uma formação que a chamamos de omnilateral, integral no sentido de que o aluno ele está tendo acesso não só ao conhecimento específico da atividade laboral ali, do trabalho propriamente dito, da habilidade que o trabalho exige, mas ele está tendo acesso também ao conhecimento dos fenômenos, sejam sociais, naturais que envolvem toda a profissão. (P1)

Bom, a primeira questão do ensino médio integrado é que o aluno além de ter a formação do ensino médio comum, eles saem do Instituto Federal com o diploma de técnico em alguma área [...], eles já podem estar apto a atuar no mercado de trabalho. (P2)

Bem, o Instituto tem essa previsão de ofertar um ensino profissional, então ao invés de ofertar só o curso técnico específico, ele atrela a ele o ensino médio[...]. (P3)

Bom, eu acho que é uma forma de capacitação, estar tentando capacitar essas pessoas para o mercado de trabalho e junto com o ensino integrado [...]. (P4)

Vemos no discurso dos entrevistados que não há contrariedade entre suas concepções e os objetivos da Instituição, que inclui a formação profissional. É interessante saber se esses docentes que exercem função de gestão e coordenação reconhecem que a clientela assistida pelo IFNMG-Januária procura a Instituição mais pelo ensino propedêutico para prosseguimento nos estudos do que pela necessidade ou desejo da formação profissional, como apontou a pesquisa quantitativa. Vejamos então a próxima subcategoria. 
Subcategoria: Percepção do Desejo Formação Discente

A pergunta foi: "Na sua percepção o que mais atrai os alunos ao IFNMG Januária: a profissionalização ou o ensino propedêutico para prosseguimento em estudos de nível superior". A nuvem de palavras criada a partir das falas transcritas dos entrevistados denota bem o resultado para essa questão salientando a qualidade da formação propedêutica, vejamos os discursos.

Figura 4 Nuvem de Palavras Atratividade do Ensino Integrado

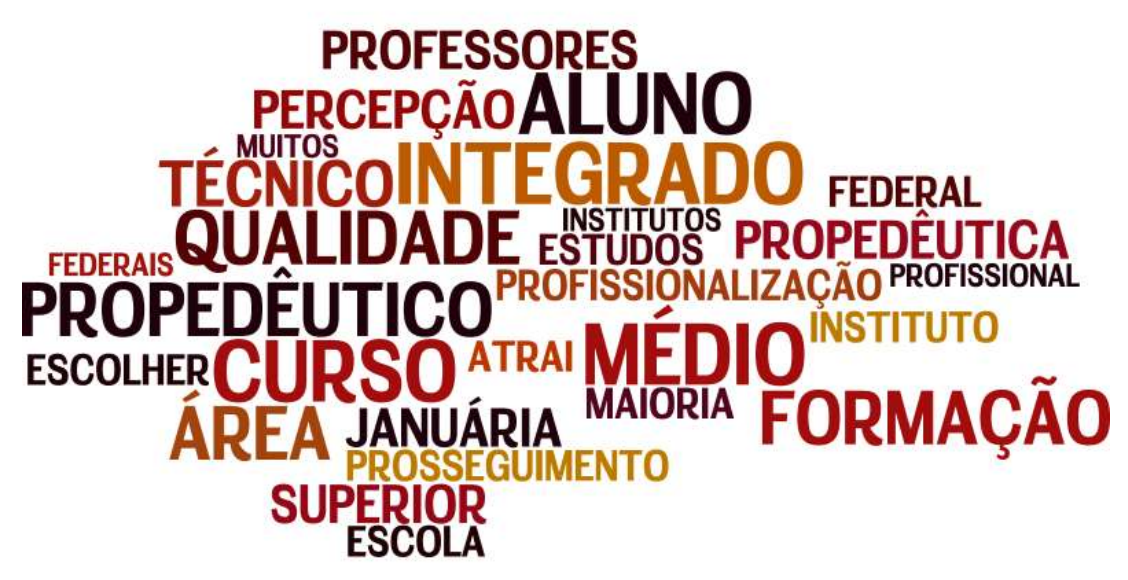

Fonte: Pesquisa de Campo 2015

O ensino propedêutico, a grande maioria vem procurando o ensino médio de qualidade. (P4)

[...] por nós termos um ensino com muita qualidade na parte propedêutica, assim como também na parte técnica, mais especificamente na propedêutica, e a nossa região ela é uma região carente, as escolas públicas infelizmente não têm a capacitação que nós temos, professores, veja bem, professor de Matemática doutor em Matemática, professor em Física, doutor em Física ministrando aulas em escolas públicas não é muito comum, só é comum em Institutos Federais, [...]mas hoje nós temos ainda um percentual de alunos que veem com um forte interesse apenas no parte propedêutica, mais nós estamos trabalhando para mudar esse cenário.(P2)

[continua] 
Já é perceptível e discutido com alguns professores, e o que mais nós observamos é a questão do ensino propedêutico, a qualidade que o ensino oferece mesmo, sendo integrado ao ensino profissionalizante, e contribuindo de certa forma paras as disciplinas técnicas. Mas assim, o aluno de certa forma ele vem mais com interesse com a educação propedêutica, não na totalidade, mais a maioria é. (P3)

O ensino propedêutico, isso aí é fato, a gente sabe disso, apesar de que eu não acho que isso seja uma pedra tão grande no nosso caminho, como muitos professores costumam pensar. Por que que eu falo isso? Os Institutos Federais ao meu ver eles têm uma característica muito peculiar, eles estão adentrando nos municípios mais pobres, menores, as regiões... não só as mais carentes, é o caso do Instituto Federal do Norte de Minas, mas regiões que não são centro, capital, centro econômico enfim. E muitas vezes essas cidades, a única opção de uma escola de ensino médio de qualidade que a cidade oferta está no Instituto Federal. (P1)

Na pesquisa quantitativa os discentes informaram que o fator prosseguimento nos estudos foi o que mais os influenciou a escolherem o ensino integrado no IFNMGJanuária. A qualidade do ensino propedêutico conjugada a uma região pouco desenvolvida, carente de boas instituições de ensino, é apontada pelos entrevistados como fator motivador da escolha do discente pelo interesse em cursar o ensino integrado do IFNMG-Januária.

Realmente, a região que o IFNMG-Januária assiste é muito carente, o Índice de Desenvolvimento Humano (IDH ${ }^{11}$ ), da microrregião de Januária varia entre 0,529 a 0, 658; sendo respectivamente, os municípios de São João das Missões e o de Januária, o que denota ainda mais a importância da profissionalização nessa região para alavancar o crescimento socioeconômico, entretanto a clientela assistida pelo IFNMG-Januária está mais preocupada com o ingresso nos cursos superiores.

Interessante na fala do entrevistado P1, em um determinado momento de sua resposta, quando disse que "a referência de ensino médio é o Instituto Federal, e essa referência ela foi reforçada naquela época, com o Decreto 2.208/97 que foi proibido o ensino integrado", o que nos indica que o Decreto 2.208/97 agravou ainda mais o cenário das Instituições Federais em época das Lei n. 5.692/71 e Lei n. 7.044/82, ou seja, deixou ainda mais atrativo o ensino médio de qualidade das Instituições Federais

\footnotetext{
${ }^{11}$ Fonte: http://www.cdljanuaria.com.br/page/apres_p.pdf
} 
e não a profissionalização; corroborando ainda mais com o dualismo apontado por Carvalho(2003). Vejamos:

Então naquele momento que a gente passou a oferecer aqui o ensino médio separado do ensino integrado, aquilo reforçou ainda mais a característica da escola, enquanto uma escola formadora de ensino médio com qualidade, então isso perdura até hoje no imaginário, na percepção que a população tem sobre a nossa instituição. (P1)

Em outro momento da entrevista, o Participante P1 nos revela que antes da Lei das cotas o curso de informática integrado tinha aproximadamente $100 \%$ de alunos oriundos de escolas particulares, corroborando com as colocações de Castro (2005, p.52) e Castro (Castro, 1997, p.142) quando disse que no ensino integrado (em fins da década de 80) os discentes eram oriundos cada vez mais das classes média e alta, "e não pensavam em nada além dos vestibulares para as melhores universidades, fossem os de direito, fossem os de medicina", e que ficavam as indústrias sem os técnicos que precisavam para serem competitivas, e a "ver navios os alunos mais modestos, interessados nas ocupações técnicas oferecidas".

Hoje a gente tem cursos, é o caso do curso da informática, antes da lei das cotas, nós tínhamos um curso de informática integrado com aproximadamente $100 \%$ de alunos oriundos de escola privadas, era um índice muito alto. Com $50 \%$ de cotas pra alunos da escola pública, o nosso perfil mudou muito, eu acho que ficou muito bacana, você ter essa diversidade e poder atender alunos que têm uma possibilidade maior de envolver uma formação profissional [...] (P1).

O Relato do Participante P1 nos informando que havia quase $100 \%$ dos alunos oriundos de escola particular antes das cotas nos remete a pesquisa de Rodriques (2011) e Loponte (2010) no Capítulo 1.

Como vimos em Rodrigues (2011) o pesquisador verificou que os alunos concluintes eram oriundos de escolas públicas enquanto os evadidos eram oriundos de escolas particulares, e que os alunos concluintes entrevistados falaram de sua total dedicação e compromisso com o curso, enquanto que os alunos evadidos mencionaram não estar comprometidos com o curso por falta de identificação. 
Em Loponte (2010) com 73,5\% de discentes oriundos de escola particular, a pesquisadora concluiu que a família por já possuir recursos financeiros não necessitaria que o filho começasse a trabalhar tão logo concluísse o curso técnico, incentivando assim a sua entrada em um curso superior.

Essas informações nos traz o indicativo que a clientela que usufrui mais eficientemente os objetivos da política pública, ou seja, usufrui tanto o eixo propedêutico quanto o eixo profissionalizante, pode ser aquela mais modesta, oriundas de escolas públicas, como também apontou os estudos de Jesus, E. e Jesus, V. (2013) quando observou que $88 \%$ dos alunos que faziam o ensino integrado no IFSP em parceria com o ensino médio do estado pretendem em princípio atuar no mercado de trabalho ao término do curso, e na percepção do participante $\mathrm{P} 1$, com as cotas pode se "atender alunos que têm uma possibilidade maior de envolver uma formação profissional".

\section{Quadro de Categorização II}

\begin{tabular}{|c|c|c|c|}
\hline $\begin{array}{l}\text { Caracterização } \\
\text { do Estágio } \\
\text { Supervisionado }\end{array}$ & Importância & $\begin{array}{l}\text { Vivencia real } \\
\text { como profissional } \\
\text { da área } \\
\text { Realidade do } \\
\text { mundo trabalho }\end{array}$ & $\begin{array}{l}\text { "O estágio é um momento que o aluno } \\
\text { vai ter contato com a realidade, um } \\
\text { momento que ele vai aprender, que ele } \\
\text { vai compreender o contraste, a } \\
\text { contradição que existe entre aquilo que } \\
\text { é ensinado e muitas vezes aquilo que é } \\
\text { feito e torna isso, essa contradição } \\
\text { objeto de aprendizagem." (P1) } \\
\text { "[...] o técnico realmente ele só } \\
\text { aprender, ele só vai assimilar o que ele } \\
\text { está vendo na teoria, a partir do } \\
\text { momento que ele começa a praticar e } \\
\text { vivenciar as situações que ocorrem no } \\
\text { cotidiano de uma empresa [...] eu vejo } \\
\text { como uma extrema importância o } \\
\text { estágio porque é nessa oportunidade } \\
\text { que ele vai ter de praticar e de vivenciar } \\
\text { as situações cotidianas [...]". (P2) } \\
\text { "Ele oferece ao aluno uma experiência } \\
\text { além da prática além das disciplinas, } \\
\text { durante o curso. Como muitos alunos } \\
\text { acabam fazendo o estágio em } \\
\text { instituições fora do campus Januária, } \\
\text { eles começaram a verificar de certa } \\
\text { forma o mundo do trabalho, o mercado } \\
\text { de trabalho." (P3) }\end{array}$ \\
\hline
\end{tabular}




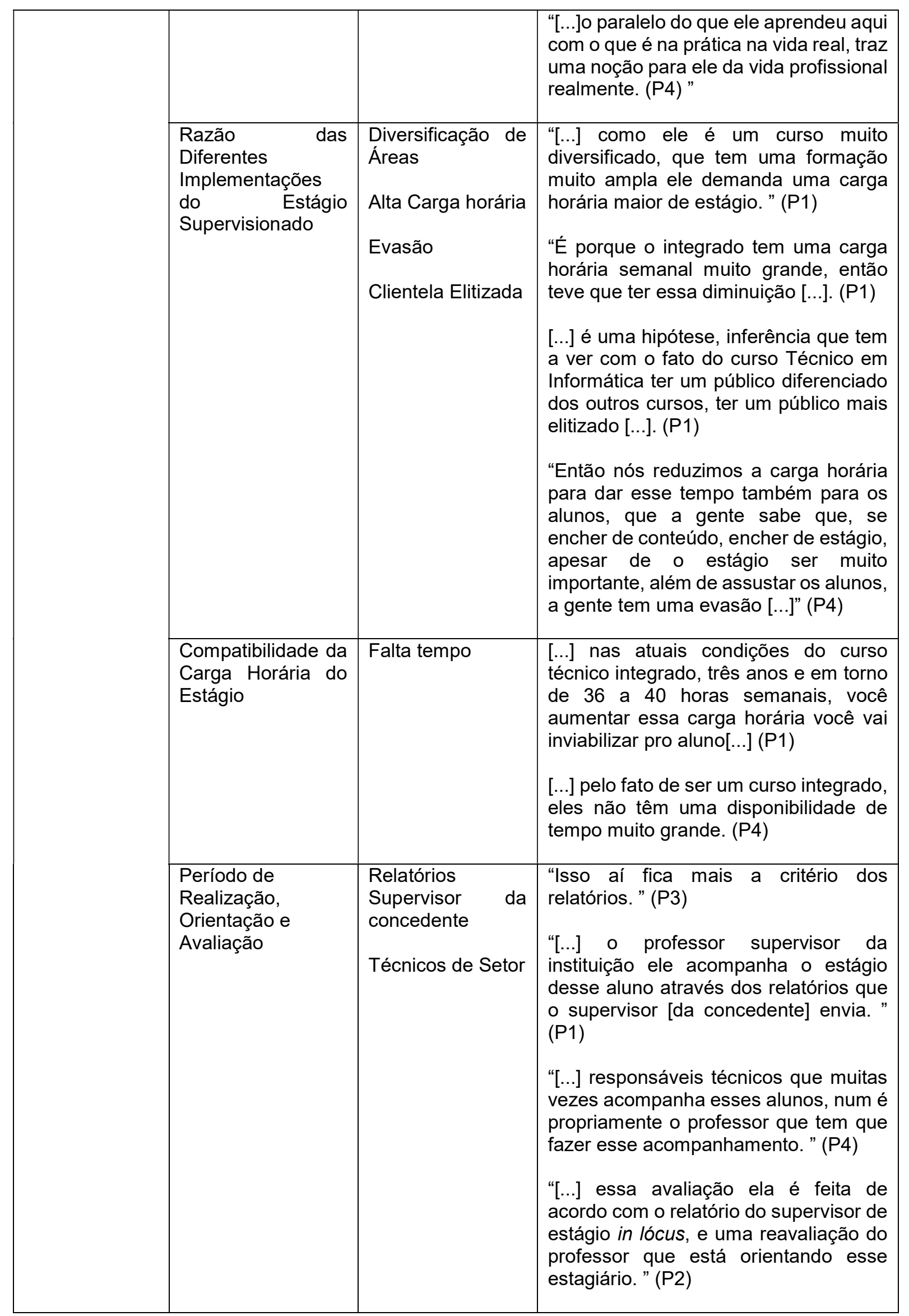




\begin{tabular}{|c|c|c|}
\hline $\begin{array}{l}\text { Percepção de } \\
\text { Extensão do Curso } \\
\text { para mais de três } \\
\text { anos }\end{array}$ & $\begin{array}{lr}\text { Interesse } & \text { no } \\
\begin{array}{lr}\text { ENEM } \\
\text { evasão }\end{array} & \text { causaria } \\
& \\
\text { Ingresso } & \text { de } \\
\text { Clientela } & \text { mais } \\
\text { interessada } & \text { na } \\
\text { parte } & \\
\text { profissionalizante } \\
\text { Melhora } & \text { a } \\
\text { Formação } & \end{array}$ & $\begin{array}{l}\text { "[..] abriria esse leque de alunos que } \\
\text { tem interesse e envolvimento maior } \\
\text { com o curso. Agora o meu receio que é } \\
\text { baseado nos relatos que eu estou } \\
\text { escutando é com a evasão...". (P1) } \\
\text { "Na minha opinião essa seria uma } \\
\text { excelente opção para acabar com o } \\
\text { aluno que só quer o ensino médio. " } \\
\text { (P2) } \\
\text { "Bem, pensando o ponto de vista da } \\
\text { formação, seria mais viável porque ele } \\
\text { desenvolveria com mais calma, com } \\
\text { mais práticas, propriamente dito." (P3) } \\
\text { "... a gente corre o risco de chegar no } \\
\text { último semestre do curso, o aluno já } \\
\text { passar pela prova do Enem, e não } \\
\text { querer mais dar continuidade, ter uma } \\
\text { evasão muito grande..." (P3) } \\
\text { "...uma das coisas que a gente poderia } \\
\text { pensar e ampliar seria também a carga } \\
\text { horária, que realmente } 80 \text { horas só pra } \\
\text { ver toda a área de conhecimento que } \\
\text { meio ambiente abrange num é tão } \\
\text { grande." (P4) }\end{array}$ \\
\hline $\begin{array}{l}\text { Compartilhamento } \\
\text { de Saberes }\end{array}$ & $\begin{array}{l}\begin{array}{l}\text { Não existe } \\
\text { formalizado }\end{array} \\
\text { Compartilhar } \\
\text { experiências } \\
\text { diferentes }\end{array}$ & $\begin{array}{l}\text { "[...] deveria haver porque é como eu } \\
\text { disse, cada um vai ter a sua vivência } \\
{[\ldots . .] \text { " (P2) }} \\
\text { "Eles têm essas coisas mesmo mais } \\
\text { informais [...]". (P3) } \\
\text { "[...] em setores, em instituições que } \\
\text { eles não fizeram, eles conhecerem um } \\
\text { pouco da realidade daquilo ali [...]" (P4) }\end{array}$ \\
\hline
\end{tabular}

\section{Categoria 2: Caracterização do Estágio Supervisionado}

\section{Subcategoria: Importância do Estágio Supervisionado}

Qual a importância do estágio supervisionado nos cursos profissionalizantes do IFNMG-Januária? Com essa questão queríamos entender o fato do estágio ser tão importante nos documentos do IFNMG, para os cursos profissionalizantes em geral, mas contraditoriamente a pesquisa quantitativa apontar desconhecimento sobre o tema estágio supervisionado por grande parte dos discentes, além de outras falhas de operacionalização. 
Portanto, nessa categoria, iniciaremos abordando o discurso dos entrevistados sobre o grau de importância que eles conferem ao estágio supervisionado para em seguida acarear com o modo do qual o estágio supervisionado é divulgado na Instituição.

Nosso estágio supervisionado tem uma importância ímpar. O estágio é um momento que o aluno vai ter contato com a realidade, um momento que ele vai aprender que ele vai compreender o contraste, a contradição que existe entre aquilo que é ensinado e muitas vezes aquilo que é feito e torna isso, essa contradição objeto de aprendizagem. (P1)

[...]eu vejo como uma extrema importância o estágio porque é nessa oportunidade que ele vai ter de praticar e de vivenciar as situações cotidianas da área. Na minha opinião só aprende praticando não existe outra maneira. (P2)

Ele oferece ao aluno uma experiência além da prática além das disciplinas, durante o curso. Como muitos alunos acabam fazendo o estágio em instituições fora do campus Januária, eles começaram a verificar de certa forma o mundo do trabalho, o mercado de trabalho na área técnica [...]. Então eu acho que além de proporcionar um ganho com relação a prática, a experiência, essa questão dele levar pra lá pra essas instituições, o paralelo do que ele aprendeu aqui com o que é na prática na vida real, traz uma noção pra ele da vida profissional realmente. (P3)

É no estágio que eles vão conseguir ver a realidade, ali no dia a dia, no trabalho de técnico deles. Então muitas vezes na sala de aula, tem as aulas práticas, mais fica muito na teoria do que pode acontecer, e muitas outras vezes o professor supervisionando ali, dando mais instruções mesmo na aula prática. No estágio ele vai realmente, uma simulação do mercado de trabalho, ele vai realmente colocar a mão na massa saber como é que ele vai desenvolver o que ele está aprendendo. (P4)

Como podemos verificar no discurso, evidenciado visualmente também na nuvem de palavras (Figura 5), os docentes (Participantes) conferem ao estágio supervisionado alto grau de importância, relacionando-o com o verdadeiro momento de experiência profissional, onde o estagiário vivenciará situações reais do mundo do trabalho que somente o mercado de trabalho poderá proporcionar. 


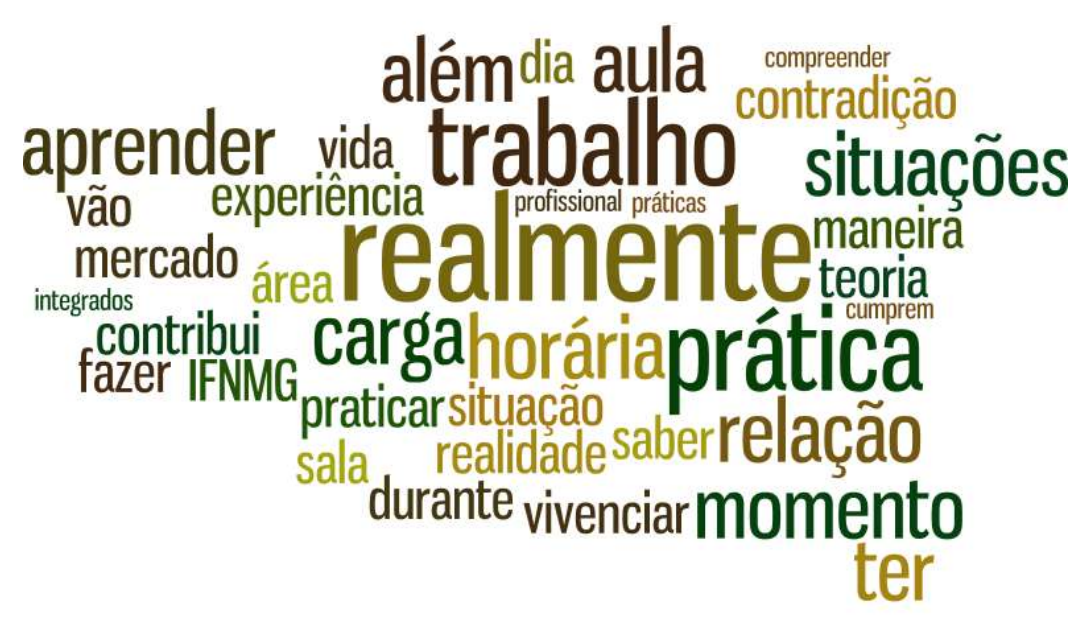

Fonte: Pesquisa de Campo 2015

Mas, sendo então o estágio supervisionado de grande importância por que existe tanto desconhecimento acerca do estágio supervisionado pelos discentes, principalmente nos primeiros e segundo anos, e excessivamente no curso de Informática?

Como vimos, foi muito elevado o porcentual de discentes que informaram desconhecimento da atividade estágio supervisionado (Agropecuária: 54\%, Informática: $66 \%$ e Meio Ambiente: $51 \%$ ) e também que a instituição não informou ou deu acesso a algum documento explicando o que é estágio supervisionado e seu funcionamento (Agropecuária: 58\%, Informática: 90,2\% e Meio Ambiente: 78\%). Para entender essa situação fizemos a pergunta: "Como e quando são disponibilizadas as informações acerca do estágio supervisionado aos discentes? "

Todos os entrevistados informaram que informações gerais sobre o estágio são dadas no primeiro ano, mas é no segundo ano (momento em que eles já podem iniciar o estágio) que é feito o aprofundamento do tema com os alunos, separamos duas falas que explicitam o modo como é divulgado: 
No início do segundo ano, porque eles começam a desenvolver estágio no segundo ano do curso, isso, no início, durante o segundo ano, antes das primeiras férias, que eles vão ter em julho, então eles têm que ter, claro que a gente já disponibiliza informações mais esse aprofundamento, essa orientação, o regulamento como funciona é sempre no início do segundo ano. (P1)

As informações elas são disponibilizadas a todo início de ano, com relação a estágio. No caso do integrado [informática] essas informações elas são dadas de forma geral, até porque não é obrigatório. (P2)

O estágio é reconhecido como um importante elemento na formação profissional, porém essa reconhecida importância não está se refletindo na divulgação do mesmo, visto o alto grau de desconhecimento do componente curricular por parte dos discentes, principalmente os de informática, como vimos, 90,2\% apontaram que a instituição não informou ou deu acesso a algum documento explicando o que é estágio supervisionado e seu funcionamento, entende-se que isso é devido as informações serem "dadas de forma geral, até porque não é obrigatório", como informou o Participante (P2). Importante notar nessa fala do Participante (P2), e também em outros momentos da entrevista, um descontentamento dele com a baixa valorização do eixo profissionalizante, como se estivesse sido vencido pela situação.

No estender da conversa com o Participante $\mathrm{P} 1$, esse nos revela, que na prática, realmente o estágio supervisionado não recebe a importância que conferem os documentos, que existe um "problema sério em relação ao estágio" uma "desvalorização" do componente curricular no IFNMG-Januária, devido à alta carga horária compactada que o aluno do ensino integrado tem que cumprir em três anos.

Mas a gente tem um problema muito sério em relação ao estágio, eu não acho que o estágio tem sido valorizado, aqui no IFNMG, da maneira como deveria. E a meu ver, o que contribui pra essa, o que eu chamo de desvalorização é que eu não percebo ainda que o estágio seja discutido, seja planejado da forma como deveria ser devido a sua importância. O estágio é regulamentado, os alunos fazem, cumprem a carga horária, existe um acompanhamento, uma supervisão, mais essa discussão sobre o estágio, esse planejamento precisa ser aprimorado.

[continua] 
E o que contribui pra isso a meu ver, é a carga horária grandiosa, enorme que a gente tem aqui nos cursos integrados. Nós temos alunos que estudam entre 36 e 40 horas semanais, e que vão fazer estágio durante as férias. Então, é muito pesado, é muito puxado para o aluno, você acaba não conseguindo realmente essa articulação. (P1)

\section{Subcategoria: Razão Das Diferentes Implementações Do Estágio Supervisionado}

Sendo reconhecida a importância do estágio supervisionado nos cursos profissionalizantes pelos entrevistados, quais seriam as razões do IFNMG-Januária implementar diferentes cargas horárias ou até mesmo a possibilidade de não realizar o estágio supervisionado? A razão seria a cansativa carga horária compactada em três anos como informou a pouco o Participante P1?

Fizemos perguntas pontuais para os entrevistados a fim de esclarecer essa questão. Quanto ao fato da carga horária do estágio supervisionado para o curso integrado agropecuária possuir 150 horas e no meio ambiente 80 horas, o participante P1 acredita que é devido a maior quantidade de áreas do primeiro:

Contempla várias dimensões, o aluno ele tem uma série de disciplinas de conteúdos relacionadas, a agricultura, outras áreas, relacionadas à questão da pecuária, e ainda a mecanização agrícola, mais a agroindústria, então assim, como ele é um curso muito diversificado, que tem uma formação muito ampla ele demanda uma carga horária maior de estágio. (P1)

Porém, quando perguntado sobre as 160 horas do extinto curso técnico em Meio Ambiente subsequente enquanto que no mesmo curso na modalidade integrado é de 80 horas, o participante $\mathrm{P} 1$ informa, novamente, como razão dessa diferença a alta carga horária do ensino integrado compactada em três anos de curso, razão também compartilhada pelo participante P4 que ainda acrescentou o fator evasão. 
É porque o integrado tem uma carga horária semanal muito grande, então teve que ter essa diminuição, enquanto o curso subsequente ele só funcionava em meio período do dia, ou só manhã, ou só pela tarde, então isso possibilitava ao aluno ter maiores condições pra cursar o estágio. (P1)

[...] como era um curso só de um período, ou matutino ou vespertino, a gente entendia que os alunos tinham mais tempo pra realizar esse estágio. $O$ curso integrado os alunos têm aula praticamente assim o dia inteiro, poucos períodos de folga, e a gente sabe que realmente nas férias eles precisam descansar.

Então nós reduzimos a carga horária para dar esse tempo também para os alunos, que a gente sabe que, se encher de conteúdo, encher de estágio, apesar de o estágio ser muito importante, além de assustar os alunos, a gente tem uma evasão, poder ter uma evasão maior, eles voltariam cansados, se fosse uma carga horária muito grande, eles não conseguiriam cumprir essa carga horária do estágio, poderiam desistir do curso, ou voltar no semestre seguinte cansados e não teriam rendimento bom também de aprendizagem para eles.(P4)

Quanto ao fato do estágio supervisionado ser obrigatório no curso de informática subsequente e opcional no curso informática integrado, o Participante P2 também credita essa situação à alta carga horária do ensino integrado nos três anos, porém acredita que ainda assim é totalmente possível desenvolver o estágio nas férias como acontece nos outros cursos, ideia também compartilhada pelo Participante P1.

Eu vejo que a questão do curso subsequente por ele ser um curso apenas da área técnica, não envolvendo a área propedêutica, é um curso de formação rápida e reduzido a carga horária, essa redução de carga horária ela favorece a possibilidade do estágio, ao passo que um curso integrado, de maneira integral, no ensino manhã e tarde, oito horas diárias de estudo acaba dificultando para aquele estágio não seja na época de férias do aluno, o que para mim na minha opinião não prejudicaria em nada, seria muito possível que o aluno pegasse $o$ seu período de férias e durante seis horas por dia eles fizessem o seu estágio, e isso iria contribuir com certeza na sua formação profissional, no meu entendimento não é obrigatório no ensino médio justamente por essa questão de acúmulo de carga horária, é a minha opinião, eu acho.(P2)

Ainda em relação à opcionalidade do estágio supervisionado no curso integrado de informática, o Participante P1, informa que não participou das discussões na época da implementação, mas deixa uma importante percepção, a elitização do ensino integrado como já mencionamos anteriormente: 
[...] é uma hipótese, inferência que tem a ver com o fato do curso Técnico em Informática ter um público diferenciado dos outros cursos, ter um público mais elitizado, eu acho que isso de alguma maneira, talvez não diretamente conscientemente pesou nessa decisão, é uma hipótese que eu tenho, mas eu também não sei.

Diante dos estudos que vimos no Capítulo 1, que mostraram o desinteresse da clientela pela parte profissionalizante e falta de atenção direcionada ao estágio supervisionado, podemos deduzir, que a hipótese, a inferência que o Participante P1 nos traz, possa ser verdadeira, e acreditamos que podemos estender essa percepção como sendo a realidade de muitas outras Instituições e em diferentes cursos integrados, mas em especial os de informática.

A elitização no ensino integrado já acontecia em fins da década de 80 , como descrito por Castro (1997, p.142) ao observar a perda do espaço do ensino profissionalizante, para o autor era "muito gasto para uma clientela muito elitizada" que não se interessava pela profissionalização.

Perguntado sobre o impacto na formação do aluno de informática integrado caso ele opte em não fazer o estágio supervisionado, o Participante P1 informa que é desconhecido que discentes de informática façam o estágio supervisionado:

Eu vou te afirmar aqui que eu não tenho conhecimento de aluno que faça estágio, se tiver pode ter um, dois, é muito difícil você ter o aluno que faça o estágio. Então eu acho que o impacto disso não bom, não é dos melhores porque na verdade, eu não acho que prejudica a formação, mais o estágio melhoraria essa formação, iria aprimorar essa formação com certeza.

Ah! Só ainda sobre essa pergunta, eu penso que aquela problemática que os professores colocam, que o aluno ele não tá interessado no curso técnico, o estágio supervisionado aproximaria mais o aluno da realidade e eu penso que isso poderia contribuir para valorizar a formação profissional[...](P1)

Realmente, em contato por e-mail com a Coordenadoria de Estágios e Empregos do IFNMG-Januária, nos foi informado que "em virtude da não obrigatoriedade do estágio supervisionado obrigatório na matriz curricular do Técnico de Informática Integrado ao Ensino Médio" até aquele presente momento não havia "qualquer matrícula de estágio referente ao citado curso". 
Quanto à fala do Participante P1 no trecho: "eu não acho que prejudica a formação, mais o estágio melhoraria essa formação, iria aprimorar essa formação com certeza". Vimos na pesquisa quantitativa que a falta do estágio no curso integrado de Informática prejudicou severamente o eixo profissionalizante, e em se tratando da formação integral em que não há separação entre 0 propedêutico $e \quad 0$ profissionalizante, podemos afirmar que a formação integral do aluno foi prejudicada. Entretanto, de acordo com os resultados da pesquisa quantitativa, o Participante P1 tem razão ao dizer que: "o estágio supervisionado aproximaria mais o aluno da realidade e eu penso que isso poderia contribuir para valorizar a formação profissional", tamanha foi a diferença entre os cursos Agropecuária (estágio obrigatório) e Informática (estágio não obrigatório opcional).

Sintetizando o discurso dos entrevistados, verificamos que o estágio supervisionado teve que se adequar no que restou de disponível nos três anos de disciplinas técnicas e propedêuticas, levando-se em consideração ainda o tempo de descanso para o discente, a preocupação com a evasão foi citada nesse momento.

Ao se fazer isso, adequar o estágio supervisionado, teriam os Participantes conhecimento de que essa adequação poderia limitar o alcance dos objetivos do estágio supervisionado como vimos na pesquisa quantitativa? Com essa indagação iniciaremos a análise da próxima subseção.

Subcategoria: Compatibilidade da Carga Horária do Estágio

Foi perguntado aos Participantes se a carga horária implementada para o estágio supervisionado estava sendo suficiente para satisfazer os seus objetivos, ou seja, permear as disciplinas, promover a socialização, a análise crítica do mundo do trabalho, etc.; pois, a pesquisa quantitativa mostrou que a maioria dos estagiários apontou que as atividades no estágio supervisionado ficaram restritas a pequena parte do currículo e, ainda, $57 \%$ dos estagiários que já haviam finalizado toda a carga horária ou a finalizar, julgaram a carga horária insuficiente, dificultando a contextualização curricular e o alcance do Ato Educativo. 
Vou ser bem sincera com você, não acredito. Agora se você me perguntar, você defende o aumento dessa carga horária? Não! Por quê? Porque nas atuais condições do curso técnico integrado, três anos e em torno de 36 a 40 horas semanais, você aumentar essa carga horária você vai inviabilizar para o aluno o comprimento desse estágio. (P1)

Bom eu acredito que o estágio até poderia ter uma carga horária maior [...] quando ele começa a ter um aprendizado maior sobre aquelas questões, aquelas questões da área do estágio já está encerrando as horas do estágio e aí ele fica como se diz, partido o seu conhecimento, ele encerra por ali aquele aprendizado, ele interrompe aquele aprendizado. (P2)

Então assim, às 150 horas, no meu ponto de vista pessoal, como técnico em agropecuária, eu acho pouco para que ele possa ter uma experiência maior fora da instituição. (P3)

É, eu acho que é uma carga horária pequena, mais pelo fato de ser um curso integrado, eles não têm uma disponibilidade de tempo muito grande.

[...] o ideal é que eles fizessem esse estágio em várias empresas para ver uma série de coisas, e acaba que concentra em poucas empresas, então um carga horária maior seria bem mais interessante, mas infelizmente por ser um curso integrado de três anos, a gente não consegue aumentar muito isso ai sem acabar prejudicando a aprendizagem dos alunos. (P4)

Como vimos os Professores (Participantes) tem ciência que a carga horária não é suficiente para satisfazer os objetivos que propõe o estágio supervisionado, o entrave apontado para a adoção de uma carga horária maior no estágio supervisionado continua sendo o fator alta carga horária compactada desenvolvida pelo discente no ensino integrado de três anos, como visto também em subcategorias anteriores.

Bem, se a carga horária esta compactada em três anos, fazendo com que o aluno fique pela manhã e tarde cursando as disciplinas, qual o período que os discentes realizam o estágio supervisionado? Seria nas férias, como indicado pelo Participante P2 quando disse que "oito horas diárias de estudo acaba dificultando para aquele estágio não seja na época de férias do aluno"?

Se for realmente nas férias, o período em que os alunos realizam o estágio supervisionado, como fica o acompanhamento efetivo dos professores orientadores, 
uma vez que esses profissionais também estarão de férias? Analisaremos essa situação na subcategoria seguinte.

Subcategoria: Período de Realização, Orientação e Avaliação

Perguntamos aos Participantes o seguinte: Sendo que os alunos ficam pela manhã e tarde cursando as disciplinas, quando é que realizam o estágio supervisionado?

Nós temos alunos que estudam entre 36 e 40 horas semanais, e que vão fazer estágio durante as férias. (P1)

É, o estágio ele não pode ser realizado durante o período letivo, o máximo que pode acontecer dentro do período letivo, seria no sábado e no domingo, que é mais difícil de acontecer, porque as empresas geralmente não funcionam nesses dias. Então, o estágio ele é realizado ou nesse período de recesso, ou no período de férias regulares. Então se for o aluno deixar de assistir aula pra realizar o estágio não pode, tem que ser sempre fora do período letivo. E, uma pergunta mais cedo eu acabei me esquecendo, essa questão da socialização. Quando eu falei da experiência isso é fundamental porque ele começa a criar uma certa liberdade profissional, que ele vai, ele vai ter que tomar algumas decisões porque ele não tem o professor acompanhando diretamente, começa a adquirir outras experiências com os funcionários do local, então ele tem um trabalho mais social, e até mesmo de liderança, que ele começa a criar esses status, do mesmo propriamente dito. (P2)

A recomendação é que eles usem as férias de janeiro como são mais longas, usem as férias de janeiro pra fazer o estágio, então teria um período de descanso, pegaríamos duas semanas, três semanas pra realizar o estágio. (P3)

No período de férias como fica o acompanhamento efetivo do professor uma vez que esses profissionais também estão de férias? 
Nos setores tem responsáveis, responsáveis técnicos que muitas vezes acompanha esses alunos, não é propriamente o professor que tem que fazer esse acompanhamento, às vezes um técnico que cuida do setor pode acompanhar.

E muitas vezes eles fazem também estágio em empresas, fora da escola, então alguém nessa empresa é responsável por esse aluno.

[...] aqui na instituição eles fazem principalmente na área de ecologia. [...] Muitos dos meus alunos eles fazem estágio lá, e muitos outros também vão procurar, IEF, Prefeitura, Caritas tem outras empresas ai também que eles procuram. (P4)

O estágio ele tem dois supervisores, ele tem o supervisor professor, e tem o supervisor que é o profissional do setor produtivo que ele tá fazendo estágio. Então esse profissional ele tem uma série de atividades a cumprir também, atividades até burocráticas, de preenchimento da carga horária do aluno, ele tem que fazer relatório sobre as atividades do aluno, e ai o professor supervisor da instituição ele acompanha o estágio desse aluno através dos relatórios que o supervisor envia. (P1)

É isso ai fica mais a critério dos relatórios, porque às vezes os alunos realizam o estágio, em locais bastante distantes da instituição. Igual já aconteceu de um aluno realizar o estágio na Bahia, ai através dos relatórios de estágio, através da conversa com o professor orientador quando ele pega a documentação ele escolhe um professor orientador já conversa com esse professor, já diz para ele mais ou menos o que vai ser realizado no estágio, ai depois tem os relatórios que acompanha no final do estágio. (P3)

Tendo constatado que realmente o estágio supervisionado ocorre durante as férias, e como relatado pelos Participantes o acompanhamento se dá através dos relatórios, isso explica o porquê de $63,6 \%$ dos estagiários indicarem baixo ou nenhum acompanhamento do professor orientador ao estagiário, sendo que, desses 63,6\%; $30,3 \%$ ainda informaram que o acompanhamento do professor se reduziu a apenas assinar o relatório de estágio, também explica o fato dos alunos informarem na pesquisa, em outro momento, que o acompanhamento da concedente tem sido melhor que o acompanhamento da Instituição e Ensino.

Uma observação importante que vemos nas falas é que embora os Participantes tenham salientado a importância do estágio como o momento que proporcionará ao estudante a participação em situações reais de vida e de trabalho, 
existe a possibilidade de ele não realizar o estágio no ambiente real de trabalho, perfazendo toda ou parte da carga horária do estágio no próprio IFNMG-Januária.

\section{Subcategoria: Percepção de Extensão do Curso Para Mais de Três Anos}

Como vimos até esse momento, o fator alta carga horária compactada do ensino integrado de três anos foi por várias vezes apontado pelos Participantes como o principal elemento que impede a Instituição de dar um tratamento mais adequado ao estágio supervisionado.

Pensamos que, se o problema para não implementar uma maior carga horária do estágio supervisionado é devido à alta carga horária compactada das disciplinas propedêuticas e profissionalizantes em apenas três anos, fazendo com que o aluno fique estudando em dois turnos (manhã e tarde) cansando-o, o que impede a Instituição de aumentar o curso para três anos e meio ou quatro anos com aulas num único turno? Ainda mais que, como vimos, a pesquisa quantitativa apontou que, $79,9 \%$ dos discentes de Agropecuária, 66,3\% dos discentes do Meio Ambiente e 63,5\% dos discentes do curso de Informática, responderam que ainda assim fariam o curso integrado no IFNMG-Januária caso tivesse quatro ou três anos e meio de duração com aulas num único turno.

Um ponto interessante a ser salientado da aceitação dos discentes para um curso de maior duração, é que o maior índice de aprovação para a extensão da duração do curso se encontra com os discentes de Agropecuária, curso onde o estágio supervisionado sempre foi desenvolvido e que, como vimos, é o curso mais alinhado com a política pública do ensino integrado.

Pensamos que essa medida, além de tornar possível melhor atender o estágio supervisionado em vários aspectos, também proporcionaria maior tempo de descanso para o discente, já que esse último fator é uma preocupação recorrente nas falas dos Participantes.

Fizemos então a seguinte pergunta: "Qual a sua opinião sobre a extensão do curso integrado para três anos e meio ou quatro anos com aulas num único turno".

Vemos na nuvem de palavras abaixo que a preocupação com a evasão retorna agora com maior intensidade, e se relacionando com as palavras Terceiro (Terceiro Ano), ENEM e Superior (Ensino Superior), ou seja, que os alunos do terceiro ano 
utilizariam o ENEM para o ingresso nos cursos superiores e deixariam (evadiriam) do ensino integrado sem o completar.

Figura 6 Percepção de Aumento da Duração do Curso Integrado

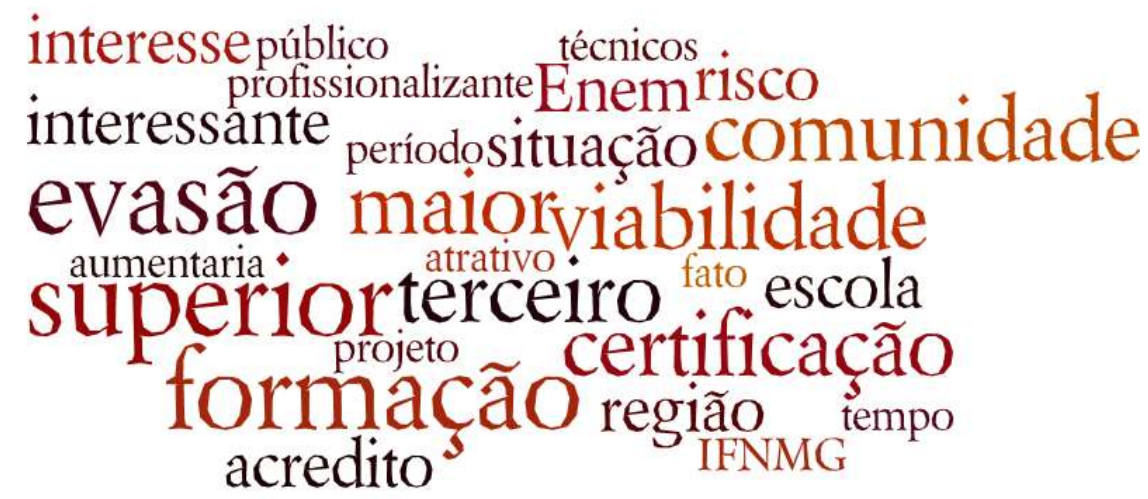

Fonte: Pesquisa de Campo 2015

Vejamos as respostas dos Participantes:

[...]eu penso que os quatro anos, a gente teria um público diferente do que a gente tem hoje, [...], abriria esse leque de alunos que tem interesse e envolvimento maior com o curso. Agora o meu receio que é baseado nos relatos que eu estou escutando é com a evasão, porque aqui na região você teria o aluno chegando no segundo, terceiro ano, evadindo ou tentando o Enem, porque ele vai chegar, olha o que eu vai acontecer, ele vai chegar no terceiro, muitos vão chegar com 18 anos, ele já vai poder fazer o Enem e conseguir a certificação no ensino médio, ele ingressa, ele passa, na faculdade, na universidade, no ensino superior e abandona o curso por causa da certificação do ensino técnico, então eu vejo isso acontecer muito aqui com alunos que estão, correndo risco de ser reprovados imagina um aluno que vai pensar, nossa eu vou ter que ficar mais um ano, sendo que eu já tenho 18 anos, eu posso conseguir no superior com minha certificação, então eu acho que tem um risco de esvaziamento.

Eu voto pelos quatro anos mais que tenha um processo de implantação, de discussão. (P1)

[continua] 


\section{$[\ldots]$}

Na minha opinião essa seria uma excelente oportunidade de opção para acabar com o aluno que só quer o ensino médio. Realmente o aluno ele iria optar por fazer um curso técnico de quatro anos ou de três anos e meio porque ele realmente quer ter aquela formação técnica, e é um período só?! Melhor ainda porque ai teria mais tempo exatamente pra parte prática que seriam os estágios, as aulas nos laboratórios às vezes, que necessita de um tempo maior em laboratório e etc. [...]

Agora, acredito que nos primeiros anos iria ter uma diminuição considerada da quantidade de alunos nos cursos técnicos. Devido a justamente essa conscientização de que o curso é profissionalizante e não só ensino médio. A partir do momento que todo mundo tivesse consciente que é curso profissionalizante, ai não importa se é de três, quatro, cinco anos, ele vai ter a formação técnica que o curso se prédispõe a oferecer. (P2)

Bem, pensando o ponto de vista da formação, seria mais viável porque ele desenvolveria com mais calma, com mais práticas, propriamente dito. [...] três anos e meio eu já vi até discutir com alguns colegas que é interessante e tudo, mais a gente corre o risco de chegar no último semestre do curso, o aluno já passar pela prova do Enem, e não querer mais dar continuidade, ter uma evasão muito grande, que ele pode pegar a certificação do ensino médio, para o curso e vai para o ensino superior. (P3)

Tem até algumas pessoas que defendem o curso integrado ser em quatro anos, uma das coisas que a gente poderia pensar e ampliar seria também a carga horária, que realmente 80 horas só pra ver toda a área de conhecimento que meio ambiente abrange num é tão grande e o ideal é que eles fizessem esse estágio em várias empresas pra ver uma série de coisas, e acaba que concentra em poucas empresas ali, então um carga horária maior seria bem mais interessante[...] (P4)

O aumento da carga horária do estágio supervisionado para valores mais adequados certamente acarretaria no aumento da duração do curso integrado para mais de três anos. Vemos nas falas dos Participantes um grande receio em estender o curso para mais de três anos, pois os discentes poderiam evadir do curso, uma vez que notadamente a preferência é pelo ingresso nos cursos superiores.

Mas cabe aqui uma observação, momentos atrás o Participante P1 informou que a proibição do ensino integrado com o decreto 2.208/97 reforçou ainda mais a característica do IFNMG-Januária "enquanto uma escola formadora de ensino médio com qualidade", e que essa visão "perdura até hoje no imaginário, na percepção que 
a população tem sobre" a instituição, e agora na fala do participante P2, ele nos diz que a evasão ocorreria nos primeiros anos, caso aumentasse a duração, devido à conscientização pelo discente "de que o curso é profissionalizante e não só ensino médio", o que faz muito sentido, ou seja, a Instituição tem uma forte característica propedêutica frente à comunidade, então ao tentar resgatar também a característica profissionalizante ocorreria o conflito e poderia ocorrer a evasão, porém com o passar do tempo poderia ocorrer à conscientização, e como o Participante P2 disse "ai não importa se é de três, quatro, cinco anos, ele vai ter a formação técnica que o curso se pré-dispõe a oferecer", perspectiva também do Participante $\mathrm{P} 1$, quando disse que tal mudança "abriria esse leque de alunos que tem interesse e envolvimento maior com o curso", ou seja, atrairia uma clientela mais alinhada aos objetivos da política pública, "um público diferente do que a gente tem hoje" como dito pelo Participante P1.

Em outro momento da entrevista o Participante P2, comentando livremente, nos relata sua percepção de que ele chamou de "imprensamento", de perda do espaço profissionalizante para o ensino propedêutico, julgando ser necessário haver um equilíbrio nas palavras dele, e que a parte profissionalizante deva receber a mesma atenção que é dada a parte propedêutica, essa perda do espaço profissionalizante para a parte propedêutica também foi observada por Castro (1997, p.142) quando disse que a parte técnica do ensino integrado, em fins da década de 80 , ou reduziu de tamanho ou foi eliminada, e atualmente também com Valaski (2012) em que o estágio supervisionado foi implantado como opcional para não atrapalhar os alunos que fossem disputar as vagas no ensino superior.

[...] nós não podemos reduzir a parte técnica em detrimento da parte propedêutica, quando o Instituto Federal na sua concepção diz que nós somos escola de formação técnica, é porque nós somos escola de formação técnica e não científico e não formação pra vestibular, formação para o Enem, só que na prática, num é isso que acontece, acaba que é forçado, nós somos imprensados ao ponto de termos que retirar ou reduzir carga horária da parte técnica pra poder encaixar a parte propedêutica, com isso o curso perde um pouco da sua característica, que é a de formação de técnicos.

[continua] 
[...]Então, um exemplo, quando no primeiro ano de um curso técnico, nós só temos duas disciplinas de nível técnico, é um forte sinal de que o curso ele tá perdendo a característica de formação técnica e tá tornando um curso de formação apenas de ensino médio, então na minha concepção, não pode haver esse imprensamento, tem que ter todas as cobranças de um profissional técnico em informática vai necessitar. [...] eu não estou dizendo que tem que diminuir a propedêutica para aumentar a técnica, mais tem que haver um equilíbrio. [...] Então a minha opinião é essa, tem que haver essa equiparação, porque quando o próprio aluno percebe que a parte técnica tá imprensada ele entende que ela não é importante, já que cedeu espaço para a parte propedêutica, e é o contrário, o ensino é integrado, todas essas disciplinas tem que estar integradas. Na prática não muito é o que acontece mais deveria ser. (P2)

\section{Subcategoria: Compartilhamento De Saberes}

$\mathrm{Na}$ pesquisa quantitativa $75,8 \%$ dos estagiários do curso integrado agropecuária informaram que não existe um momento formalizado no IFNMG Januária em que os conhecimentos vivenciados no estágio supervisionado são compartilhados. Perguntamos aos entrevistados se existia esse momento: "Existe um momento formalizado no curso onde os alunos compartilham as experiências vivenciadas no estágio supervisionado?".

Não, atualmente não. E deveria haver porque é como eu disse, cada um vai ter a sua vivência, cada um vai ter a sua experiência. $\mathrm{Na}$ verdade, particularmente em minhas aulas [...] eu peço pra que os alunos compartilhem suas experiências. (P2)

Não, específico e formalizado não! Eles têm essas coisas mesmo mais informais, às vezes na sala de aula, que as vezes algum professor dá abertura pra fazer discussão[...](P3)

Não existe, é uma coisa muito boa que eles poderiam fazer; até porque pela carga horária ser pequena, e eles acabaram indo em poucas instituições. Seria uma ideia muito boa para se empregar para que o estágio, em setores, em instituições que eles não fizeram, eles conhecerem um pouco da realidade daquilo ali, mais não infelizmente não existe nesse momento, é uma ideia. (P4)

Inferimos que a ausência de um verdadeiro acompanhamento do estagiário pela Instituição, que como vimos o acompanhamento efetivo do professor aos 
estagiários se resumiu a assinar relatórios, e também agora constatado de que realmente não existe um momento em que os estagiários compartilham os saberes as suas experiências, esse distanciamento pessoal com o estagiário, acarretou a instituição o desconhecimento de que ocorria desvios de funções nas atividades dos estagiários, situação muito importante que de acordo com a Lei 11.788/08 pode caracterizar vínculo empregatício e ainda que:

$\S 3$ o Os agentes de integração serão responsabilizados civilmente se indicarem estagiários para a realização de atividades não compatíveis com a programação curricular estabelecida para cada curso, assim como estagiários matriculados em cursos ou instituições para as quais não há previsão de estágio curricular. (Lei 11.788/08)

Esse distanciamento da Instituição com estágio supervisionado, em nosso entendimento, também acarretou o desconhecimento de que houve por grande parte dos estagiários a necessidade de aprendizado de outros conhecimentos teóricos ou práticos não abordados no curso, na pesquisa quantitativa vimos que $89 \%$ dos estagiários que já estão completando ou completaram a carga horária, informaram que houve necessidade de aprendizado de outros conhecimentos teóricos ou práticos não abordados no curso, situação que poderia ser conhecida, e depois regularizada, caso houvesse momentos formalizados de compartilhamento de saberes.

\subsection{Interpretação de Toda Análise: Ensino Integrado de Três Anos é Interessante aos já Incluídos}

Entendemos que a escolha do método misto com a técnica explanatória sequencial foi acertada, a pesquisa quantitativa nos serviu para constatar que de fato a perda do caráter profissionalizante que apontamos no capitulo 1 também acontece no IFNMG-Januária, enquanto que a pesquisa qualitativa nos serviu para ampliar os resultados e muitas vezes conhecer o porquê o fenômeno acontece. Como descrito em Creswell (2007, p. 32- 33) "os vieses inerentes a um método poderiam neutralizar os vieses oriundos de outros métodos", superamos então as limitações do uso de um único método. 
Vimos no capitulo 1, que desde a experiência de integração com Lei $n^{\circ}$ 5.692/71 até a experiência pós Decreto 5.154, estudos apontaram um forte interesse da clientela pelo eixo propedêutico para prosseguimento nos estudos em nível superior e pouco, ou nenhum interesse, pela parte profissionalizante, essa situação foi constatada também no IFNMG-Januária através da pesquisa quantitativa com os discentes, porém os dados quantitativos não nos informaram o porquê isso acontece, e também não são adequados para extrair essa percepção, mas conseguimos ter uma boa explicação com a pesquisa qualitativa.

A pesquisa qualitativa, na percepção dos entrevistados, apontou que isso acontece devido o IFNMG-Januária se encontrar em uma região carente, onde o Instituto Federal é a única opção de ensino médio de qualidade e gratuito, porém, como foi visto, os que adentram no ensino integrado da Instituição não estão interessados na profissionalização do ensino médio, e que o curso de informática especificamente já teve quase $100 \%$ de sua clientela oriundos de escolas particulares. Entendemos que esse cenário não colabora para o ideal de ensino integrado preconizado por Ciavatta, Frigotto e Ramos (2010), pois onde estariam os filhos dos trabalhadores que precisam obter uma profissão ainda no nível médio?

O ensino médio integrado é aquele possível e necessário em uma realidade conjunturalmente desfavorável - em que os filhos dos trabalhadores precisam obter uma profissão ainda no ensino médio, não podendo adiar este projeto para o nível superior de ensino - mas que potencialize mudanças para, superando-se essa conjuntura, constituir-se em uma educação que contenha elementos de uma sociedade justa. (CIAVATTA, FRIGOTTO E RAMOS, 2010, p.44)

Pela explanação dos resultados quantitativos na pesquisa qualitativa vê se indicativos que talvez os filhos dos trabalhadores que precisam obter uma profissão ainda no ensino médio não estão conseguindo adentrar nos cursos integrados do Instituto Federal devido à alta concorrência, como dito, é a única opção de ensino médio de qualidade da região.

Como é sabido, os filhos da classe trabalhadora historicamente possuem desvantagem de bagagem acadêmica para concorrerem as vagas nas instituições que oferecem ensino de qualidade, portanto, ficam sem a habilitação profissional e também sem um ensino médio de qualidade que poderia dar condições reais de 
prosseguir em estudos de graduação caso desejasse, dando então continuidade no seu ciclo de ignorância e pobreza. O que lhes resta é buscar a profissionalização em cursos estritamente profissionalizante, não integrado ao ensino médio, como o técnico subsequente.

Pensamos que podemos estender essa observação a todos os demais Institutos Federais, ou a maioria, devido ao cenário exposto no capítulo 1 e também pela situação descrita por Moura, Garcia e Ramos (2010) no próprio documento base do ensino integrado:

Uma possibilidade para os filhos da classe trabalhadora é a tentativa de ingresso em uma das instituições que compõem a Rede Federal de Educação Profissional e Tecnológica, instituições que historicamente atuam com referência em vários dos componentes que constituem a formação integral. Entretanto, tornar-se aluno dessas escolas não é fácil, pois a concorrência nos processos seletivos é muito elevada, uma vez que a quantidade de vagas que podem oferecer é muito menor do que a demanda. (Documento Base,2007, p.26)

Fato esse que já ocorria na primeira experiência de integração, quando Castro (1997, p.142) relatou que devido as escolas técnicas federais terem um esplêndido $2^{\circ}$ grau e gratuito, a alta concorrência só selecionava os melhores e "em geral, os mesmos que poderiam pagar uma escola privada e que mais adiante, entram nas universidades públicas mais competitivas".

Então, ao que parece, no IFNMG-Januária assim como ocorre em outras instituições relatadas no Capítulo 01, e também pela constatação dos dados do ENEM onde as escolas federais obtiveram as maiores médias, o ensino integrado vem incluindo os já incluídos, referenciando Kuenzer (2002): 
É sempre bom lembrar que o Ensino Médio no Brasil tem exercido, entre outras, a função de referendar a inclusão dos incluídos, justificada pelos resultados escolares. $\mathrm{Na}$ verdade, os incluídos vivenciam um conjunto de experiências sociais e culturais que lhes assegura larga vantagem na relação com o conhecimento sistematizado, isso sem falar nas condições materiais favoráveis ao estabelecimento dessa relação. Assim é que, não por coincidência, os que permanecem na escola são também os que melhor se comunicam, têm melhor aparência, dominam mais conhecimentos e apresentam condutas mais adequadas ao disciplinamento exigido pela vida escolar, produtiva e social. (KUENZER, 2002, p. 43)

Ao incluir os já incluídos, alimentamos a "realidade conjunturalmente desfavorável" descrita por Ciavatta, Frigotto e Ramos (2010, p.44), distanciando do objetivo de que esta modalidade possa "constituir-se em uma educação que contenha elementos de uma sociedade justa".

O cenário desfavorável para os filhos dos trabalhadores que precisam obter uma profissão ainda no ensino médio, se agrava com a perda do caráter profissionalizante da política pública do ensino integrado. Além de sofrerem com a alta concorrência, a política pública se mostra descaracterizada quanto a sua função de formar profissionais técnicos de nível médio, haja vista o descuido com o estágio supervisionado, não somente no IFNMG-Januária, mas em âmbito Nacional como apontou o relatório do TCU e a Pesquisa CNE/UNESCO.

Como vimos o estágio supervisionado é um forte elemento caracterizador do eixo profissionalizante, no IFNMG-Januária, ainda que com poucas horas e apresentando falhas de operacionalização, vimos que no curso de agropecuária os discentes estão bem mais alinhados aos objetivos da política pública do que os alunos de informática.

É no curso de agropecuária onde o componente curricular estágio supervisionado é obrigatório, conferindo maior identidade profissional tanto ao curso quanto aos discentes, seja na perspectiva de atuarem como técnicos de nível médio, ou na perspectiva de prosseguirem em estudos de nível superior na área de formação técnica.

Em sentido contrário está o curso de informática, que não possui estágio supervisionado obrigatório, a não realização do estágio supervisionado potencializou o caráter propedêutico, fazendo definhar a identidade profissionalizante da área de 
formação. Os discentes, quase que em sua totalidade, não se interessam em atuar como técnicos em informática e também não têm interesse em prosseguirem em estudos de nível superior na mesma área de formação técnica, desperdiçando em grande parte todo o investimento feito no eixo profissionalizante, descaracterizando a política pública tanto na formação de profissionais qualificados para o mercado de trabalho quanto no itinerário formativo.

Vimos na pesquisa qualitativa que um dos grandes problemas apontado pelos entrevistados, que inclusive impedia de se ter um estágio supervisionado mais adequado, foi a alta carga horaria dos cursos em apenas três anos.

É notório que um currículo de apenas três anos no ensino integrado torna difícil, se não impossível, desenvolver um ensino integrado de qualidade, pois como desenvolver de maneira integrada todo um currículo de ensino médio de três anos, todo um currículo de ensino técnico profissionalizante de no mínimo um ano e meio, mais o estágio supervisionado (com tudo que ele deve propiciar, permeando as disciplinas propedêuticas e técnicas) em apenas três anos?

Moura (2010) descrevendo sobre duas possibilidades de organização do ensino técnico integrado ao ensino médio (especialmente na que confere ao aluno a habilitação profissional específica, ou seja, a profissionalizante) defende que o Técnico Integrado ao Ensino Médio tenha sua carga horária e duração estendida:

Vale ressaltar que essas duas possibilidades resultam na necessidade de ampliação de carga horária do atual ensino médio majoritariamente proporcionado à população em até um ano letivo ou na intensificação da jornada escolar diária, tendo como referência os princípios comuns que constituem sua base unitária, discutida a seguir. (MOURA,2010, p.5)

Dar ao Técnico Integrado ao Ensino Médio uma carga horária e duração adequados a sua política pública, diferenciada da duração do ensino médio regular, é essencial para desenvolver o estágio supervisionado com a qualidade e importância que lhe é devida. Essa medida certamente fortalece o caráter profissionalizante tanto no discente como na Instituição, até porque é o estágio supervisionado que articula e estreita a relação entre o mercado de trabalho com a instituição e o educando. 
Portanto entendemos que o ensino integrado deva ter uma duração adequada aos seus objetivos, certamente diferente do ensino médio regular (três anos), mas enquanto o curso permaneça em três anos, nunca deve perder de vista a empregabilidade dos alunos, caso contrário continuará com a imagem de Instituição "formadora de ensino médio com qualidade" como disse o entrevistado P1, atraindo a clientela que geralmente não adentra no Instituto Federal procurando a profissionalização, mas sim o ensino médio de qualidade para melhor se preparem a disputar às vagas nos ensino superior, até porque sua identidade atualmente favorece esse cenário, como já dito identidade de Instituição "formadora de ensino médio com qualidade", favorecendo os já incluídos como atenta Kuenzer(2001):

[...] evidencia-se que a manutenção da proposta secundarista e acadêmica só serve aos já incluídos, cuja relação com o conhecimento e com a cultura se dá, de forma rica e diversificada, fora da escola. Daí o caráter propedêutico ser adequado a essa clientela, cuja relação com o trabalho produtivo dar-se-á no Ensino Superior como formação, e após sua conclusão, como exercício laboral, nas funções técnico-científicas e de gestão mais intelectualizadas e complexas, embora atualmente mais restritas pelo mercado, que exige cada vez mais numerosas e diversificadas competências. (KUENZER 2001, p.43)

Diante dos resultados da pesquisa, entendemos que o estágio supervisionado nos cursos integrados nunca deva ser ignorado nas instituições profissionalizantes, mesmo nos cursos integrados de três anos, pois se implementado mesmo com uma baixa carga horaria como visto no IFNMG-Januária, ainda assim produzirá resultados significantes, fortalecendo o caráter profissionalizante da política pública e por consequência a formação integral do educando. 


\section{CAPÍTULO 3}

\section{ORIENTAÇÕES PARA A REALIZAÇÃO DO ESTÁGIO SUPERVISIONADO NOS CURSOS INTEGRADOS DO INSTITUTO FEDERAL DO NORTE DE MINAS GERAIS}

Tendo em vista os resultados obtidos em pesquisa realizada no IFNMG Januária que evidenciou a importância do estágio supervisionado para assegurar o caráter profissionalizante nos cursos técnicos integrados, produzimos um documento contendo orientações baseadas tanto na pesquisa local quanto nas pesquisas sobre o tema estágio supervisionado discutidas até esse momento. Essas orientações se implementadas e avaliadas, tendo como piloto o Campus Januária, podem servir para que o IFNMG formule ou reformule Diretrizes para o estágio supervisionado.

A pesquisa de campo foi essencial para que de fato comprovássemos os benefícios que podem advir do componente curricular estágio supervisionado como alegam estudiosos da área e os documentos legais que regem o tema. $\mathrm{O}$ estágio supervisionado de fato demonstrou ser um componente curricular capaz de contribuir eficazmente com o eixo profissionalizante da política pública (que como foi visto encontra-se descaracterizado) balanceando melhor o eixo profissionalizante em relação ao eixo propedêutico, promovendo eficientemente a integração curricular e, por consequência, um melhor alcance dos objetivos da política pública.

Acreditamos que este produto técnico possa auxiliar no debate institucional e aprimoramento da política de estágio praticada nas Instituições que ofertam o ensino integrado, de modo a valorizar esse importante componente curricular, consolidando o caráter profissionalizante da política pública assim como está consolidado o caráter propedêutico, integrando de fato a política pública, unificando seus eixos, pois entendemos como necessária e adequada à formação dos cidadãos. 


\section{Considerações Preliminares}

Existem dois pontos polêmicos e críticos quanto ao estágio supervisionado que devem ser observados e aprofundados inicialmente: a questão da obrigatoriedade e a questão da carga horária.

São polêmicos porque não existe uma definição clara sobre eles nos documentos legais que regem o tema, cabendo então à interpretação de cada Instituição, e são críticos porque são dois pontos fundamentais que por si só já garantem ganhos expressivos e que darão a base para que o componente curricular possa se enriquecer através da observação, análise e aprimoramento, pois como sabemos, o estágio supervisionado envolve mais do que implementa-lo e assegurar uma carga horária adequada.

Portanto, esses dois assuntos serão aprofundados para melhor servirem de ponto de discussão nas instituições que possuem o estágio supervisionado opcional a seus alunos, ou que o possuem obrigatoriamente, mas com uma carga horária que talvez esteja limitando sua eficiência, o aprofundamento desses dois elementos também se faz necessária para melhor esclarecer as orientações que são trazidas. Portanto, traremos importantes reflexões e levantamentos sobre esses dois pontos principais, inclusive traremos discussões que já ocorreram em Pareceres do CNE que se mostram importante resgatar nesse momento de descuido com o estágio supervisionado.

Em seguida, serão tratados também outros elementos (outras orientações) que integram o estágio supervisionado e que durante toda a pesquisa se mostraram com grande potencial de influenciar positivamente a experiência do estagiário, portanto, se observados e bem trabalhados, certamente contribuirão para o enriquecimento do componente curricular que por consequência enriquecerá e fortalecerá o caráter profissionalizante da política pública. 


\subsection{O Estágio Supervisionado: Breve Introdução}

A Lei de Diretrizes e Bases da Educação Nacional, LEI No 9.394, DE 20 DE DEZEMBRO DE 1996, em seu Art. 82, descreve que "Os sistemas de ensino estabelecerão as normas de realização de estágio em sua jurisdição, observada a lei federal sobre a matéria".

A atual Lei Federal 11.788, de 25 de Setembro de 2008, dispõe sobre o estágio de estudantes, seu texto engloba diferentes níveis e modalidades de ensino. Em seu Art. $1^{\circ}$ assim define o Estágio:

Estágio é ato educativo escolar supervisionado, desenvolvido no ambiente de trabalho, que visa à preparação para o trabalho produtivo de educandos que estejam freqüentando o ensino regular em instituições de educação superior, de educação profissional, de ensino médio, da educação especial e dos anos finais do ensino fundamental, na modalidade profissional da educação de jovens e adultos.

$\S 1^{\circ} \mathrm{O}$ estágio faz parte do projeto pedagógico do curso, além de integrar o itinerário formativo do educando.

$\S 2^{\circ} \mathrm{O}$ estágio visa ao aprendizado de competências próprias da atividade profissional e à contextualização curricular, objetivando o desenvolvimento do educando para a vida cidadã e para o trabalho. (Lei 11.788/08)

\subsubsection{A Questão da Obrigatoriedade}

Talvez por essa definição abrangente da Lei 11.788/08, sem especificar regras para os diferentes níveis e modalidades, englobando cursos que proporcionam a habilitação profissional específica e cursos de preparação básica para o trabalho, deixou de enfatizar a importância do estágio supervisionado no ensino profissionalizante, dando abertura para que as instituições de ensino profissionalizante optassem por não implementar o estágio supervisionado obrigatório 
ou não obrigatório (sem ser opcional ${ }^{12}$ ) na grade curricular dos seus cursos técnicos, comportamento que seria mais compreensível na modalidade de ensino que não possui o objetivo específico da profissionalização, como por exemplo a educação especial e até mesmo o ensino médio regular. A questão da obrigatoriedade é encontrada no $\operatorname{Art} .2^{\circ}$ da Lei $11.788 / 08$ :

Art. 2ㅇ O estágio poderá ser obrigatório ou não-obrigatório, conforme determinação das diretrizes curriculares da etapa, modalidade e área de ensino e do projeto pedagógico do curso.

$\S 1$ 을 Estágio obrigatório é aquele definido como tal no projeto do curso, cuja carga horária é requisito para aprovação e obtenção de diploma.

$\S 2$ 을 Estágio não-obrigatório é aquele desenvolvido como atividade opcional, acrescida à carga horária regular e obrigatória.(LEI 11.788/08)

O PARECER CNE/CEB 35/2003, descrevendo o relatório final da comissão temática mista sobre estágio, constituída pelo senhor Procurador-Geral da República, composta por membros do Ministério Público do Trabalho e por representantes do CIEE- Centro de Integração Empresa Escola e do Instituto Euvaldo Lodi- IEL/CNI, com participação da Secretaria de Inspeção do Trabalho, do Ministério do Trabalho e Emprego, enfatiza a importância do estágio no ensino médio e principalmente nos cursos superiores e profissionalizantes, pois esses dois últimos "se voltam a uma profissão, cujos conhecimentos estão sendo adquiridos, exigindo a contrapartida prática para a inserção do profissional".(PARECER CNE/CEB 35/2003, p.16). Vejamos:

12 Observa-se no Parecer N. : CNE/CEB 35/2003 que a categoria de estágio "não obrigatório" possui características diferenciadas do estágio dito "obrigatório", como por exemplo a possibilidade de remuneração, e caso a Instituição optar em incluí-lo na grade curricular dos seus cursos, o estágio caracterizado como "não obrigatório" deverá ser obrigatoriamente desenvolvido pelos seus alunos ainda que leve esse nome: "não obrigatório". 
O relatório em questão analisa detidamente os dispositivos da LDB em relação ao ensino médio, para concluir que o estágio curricular dos alunos do ensino médio deve "proporcionar o conhecimento prático do ambiente de trabalho, das relações de trabalho, da estrutura de uma empresa e sua importância e papel na economia local e nacional, de modo a serem trabalhados os conceitos teóricos obtidos no âmbito da linguagem, da matemática, da história, da física e, ainda, os conceitos obtidos sobre trabalho, sua valorização e ética, sem perder de vista, naturalmente, a realidade do mercado de trabalho e o fato incontestável de sua mutação constante".

A seguir, o referido Relatório traz à colação o item 3.2 da Lei Federal $\mathrm{n}^{\circ}$ 10.172/01, que aprova o Plano Nacional de Educação, os itens 2.3 e 4.4 do Parecer CNE/CEB $n^{\circ} 15 / 98$, que deu ensejo à Resolução CNE/CEB $n^{\circ}$ 03/98, definidora de Diretrizes Curriculares Nacionais para o Ensino Médio, enquanto etapa de consolidação da Educação Básica, para concluir que, "ao contrário do estágio no ensino superior e no ensino profissionalizante, que se voltam a uma profissão, cujos conhecimentos estão sendo adquiridos, exigindo a contrapartida prática para a inserção do profissional que se prenuncia no mercado de trabalho, o estágio no ensino médio se apresenta, antes, como uma preparação básica para o trabalho", o que não deve ser confundido, obviamente, com "programas de primeiro emprego", embora possam, de fato, contribuir para a obtenção desse "primeiro emprego". (PARECER CNE/CEB 35/2003, p.16)

No mesmo sentido, uma análise jurídica feita pelo Desembargador Ricardo Tadeu Marques da Fonseca ${ }^{13}$ corrobora também com nosso posicionamento de que o estágio supervisionado nas instituições profissionalizantes deva merecer maior atenção, não o nivelando na mesma importância que possui nas instituições não profissionalizantes. No artigo "As formas de aprendizagem no Brasil: questões emergentes", de autoria do Desembargador, destaca-se questões e reflexão importantes relacionadas a Medida Provisória $n^{\circ}$ 2.164-41/01 que impactou a Lei 11.788/08:

13 Desembargador do Trabalho do Tribunal Regional do Trabalho do Paraná; professor universitário; doutor em Direito das Relações Sociais pela UFPR; especialista e mestre em Direito do Trabalho pela USP. 
Sempre defendi a inconstitucionalidade dessa medida provisória, tanto formal quanto material. Primeiro porque a regulamentação do estágio, embora relevante, não se deveria dar em caráter de urgência, como prescreve o art. 62 da Constituição Federal, por razões que, pela obviedade, dispensam maiores comentários. Segundo, e mais importante, porque o estágio propiciado em relação aos jovens do ensino médio comum não se justificava, pois a formação educacional básica não apresentava características profissionalizantes. E para que apresentasse eventualmente, seria necessário, conforme prescrevia o art. 82 da Lei $n^{\circ}$ 9.394/96, uma prévia qualificação dos currículos escolares, de modo a torná-los profissionalizantes em caráter metodicamente orientado. Fiquei, no entanto, vencido, pois, em decorrência daquela medida provisória, editou-se, em 26 de setembro de 2008, a Lei $\mathrm{n}^{\circ} 11.788 / 08$. (FONSECA, 2013, p.102)

A falta de clareza sobre o assunto estágio supervisionado rendeu importantes discussões ainda em 2002 relatadas no Parecer CNE/CEB N. o: 35/2003 que descreveu a situação como polêmica e controversa.

Em 06/11/02, a Secretaria de Educação Média e Tecnológica do MEC, conjuntamente com a Secretaria de Inspeção do Trabalho, do Ministério do Trabalho e Emprego, encaminhou ao Colegiado uma nota técnica contendo informações relativas às "polêmicas e controvérsias quanto à forma como o estágio no ensino médio é aplicado nas escolas". (PARECER N. ': CNE/CEB 35/2003, p.2)

Sobre a importância da obrigatoriedade do estágio supervisionado nos cursos de nível técnico da educação profissional o Parecer N. : : CNE/CEB 35/2003 explana:

A modalidade Educação Profissional é aqui contemplada no seu sentido mais amplo, da maneira como é tratada pela LDB (Lei Federal $n^{\circ}$ 9394/96) e também pelo Decreto $n^{\circ} 2208 / 97$, isto é, nos níveis Básico, Técnico e Tecnológico. Em vários cursos de nível tecnológico ou técnico, em função da própria natureza das ocupações objeto de educação profissional, o estágio profissional supervisionado é obrigatório. É uma decorrência natural e essencial dos próprios propósitos educacionais de profissionalização. Ninguém duvida, por exemplo, da exigência de estágio profissional supervisionado para alunos de enfermagem, radiologia médica, edificações, mecânica, química tecnológica etc...

[continua] 
Em outras áreas esse mesmo estágio pode não ser uma exigência essencial para o processo de profissionalização, mas pode ser intencionalmente assumido pela escola como um ato educativo, que representa uma ótima oportunidade de enriquecimento curricular como é o caso, por exemplo, de estágio para alunos dos cursos de contabilidade, secretariado etc...(PARECER N. ${ }^{\circ}$ : CNE/CEB 35/2003, p.6)

Do trecho acima do Parecer N. ${ }^{\circ}$ : CNE/CEB 35/2003 em que se diz que alguns cursos o estágio pode não ser uma exigência essencial para o processo de profissionalização de alguns cursos, concordamos em parte somente se ele estiver se referindo a uma instituição de ensino que possui uma estrutura altamente qualificada, muitíssima similar a encontrada no mercado de trabalho; e, somente se, analisarmos apenas a questão da prática e técnica e deixarmos de lado todas as outras experiências que somente o ambiente real de trabalho propicia (análise crítica do cenário produtivo, socialização, cobrança de resultados, relação direta com profissionais experientes da área...), o que não é sensato fazer quando se valoriza a formação humana e não apenas a técnica.

Ainda que seja assim, somente a prática e a técnica, a formação de identidade exercida sobre o discente no ambiente empresarial capitalista é diferente da formação exercida sobre o discente no ambiente acadêmico. Logo, por mais que a escola se esforce em simular o ambiente real nunca o conseguirá (assim espera-se), pois seu olhar sobre o discente é diferenciado, precisa ser diferenciado, não se vê o discente como mão de obra para produzir lucro, então, com a ausência do estágio supervisionado, será inevitável a perda das ricas experiências proporcionadas pelo real ambiente de trabalho, pelo mundo do trabalho, e futuramente, quando o discente se deparar com a pressão psicológica existente no ambiente do mercado de trabalho capitalista, não terá o efetivo apoio e supervisão da instituição de ensino.

Sendo que o estágio supervisionado "pode ser intencionalmente assumido pela escola como um ato educativo, que representa uma ótima oportunidade de enriquecimento curricular", como descreve o Parecer N. ${ }^{\text {: }}$ CNE/CEB 35/2003, pensamos que não é de bom senso as instituições que conferem habilitação profissional ignorar esta importante atividade, não se vê vantagem nisso na formação integral do educando, a pesquisa de campo mostrou que mesmo com uma baixa carga horária e com deficiências na operacionalização, o estágio supervisionado 
proporcionou uma rica experiência nos diversos aspectos que o caracteriza, deixando os estagiários confiantes em enfrentar o mercado de trabalho, uma rica experiência e confiança que não foi encontrada no curso que possui o estágio supervisionado de categoria não obrigatório opcional.

Em outro trecho do Parecer, explicitando ainda mais essa questão da opção da instituição em optar ou não pelo estágio supervisionado temos:

Ela pode fazer parte da essência do curso, como por exemplo, o estágio curricular em um curso técnico de enfermagem, caso em que o estágio supervisionado é exigido como obrigatório em função de exigências decorrentes da própria natureza da ocupação, onde o estágio é de presença obrigatória - é uma condição essencial para a adequada habilitação profissional técnica. Por outro lado, há o caso da habilitação profissional que não exigiria estágio obrigatório, como por exemplo, na área da informática, onde a atividade prática em laboratório pode suprir adequadamente essa necessidade de "praticagem profissional". (PARECER N.': CNE/CEB 35/2003, p.32)

O próprio parecer que foi elaborado para resolver as controvérsias se mostra, em certa medida, controverso, pois o mesmo informa em outro momento que a atividade prática em laboratório não elimina a necessidade do estágio supervisionado ("praticagem profissional").

Na realidade, não há uma distinção absoluta entre prática profissional simulada, em situação de laboratório e o estágio profissional supervisionado, em situação real de trabalho: há um "continuum" entre uma e outra atividade. A prática profissional é essencialmente simulada e em situação controlada, de laboratório. O estágio profissional supervisionado é realizado em situação real de trabalho, não é simulado e o ambiente não é controlado, como em laboratório - no estágio supervisionado 0 aluno, com acompanhamento direto do seu supervisor ou orientador de estágio, é colocado diante da realidade do mundo do trabalho e é chamado a enfrentar e responder a desafios inesperados e inusitados. A escola deve planejar de forma integrada a prática profissional simulada e o estágio profissional supervisionado. Uma atividade complementa a outra e se enriquecem mutuamente. Elas devem ser consideradas no seu conjunto, no projeto pedagógico do estabelecimento de ensino, sem que uma simplesmente substitua a outra. As duas atividades curriculares têm objetivos educacionais diferenciados e complementares. (PARECER N. ${ }^{\circ}$ : CNE/CEB 35/2003, p.37) 
$\mathrm{Na}$ citação acima o Parecer trata diretamente da educação profissional e enfatiza a importância do estágio supervisionado mesmo para os cursos onde o estágio "não seja essencial". Essa definição se mostra mais adequada para o ensino profissionalizante, pois é difícil, se não impossível, uma instituição de ensino simular em perfeição o mundo capitalista do trabalho, já que as intenções desses atores sobre os discentes são diferentes, sendo, portanto, incoerente eliminar a vivência da situação real de trabalho. Enfim, na resolução do Parecer N.: CNE/CEB 35/2003, temos:

Artigo $5^{\circ}$ São modalidades de estágio curricular supervisionado, a serem incluídas no projeto pedagógico da Instituição de Ensino e no planejamento curricular do curso, como ato educativo:

Estágio profissional obrigatório, em função das exigências decorrentes da própria natureza da habilitação ou qualificação profissional, planejado, executado e avaliado à luz do perfil profissional de conclusão do curso;

Estágio profissional não obrigatório, mas incluído no respectivo plano de curso, o que o torna obrigatório para os seus alunos, mantendo coerência com o perfil profissional de conclusão do curso;(PARECER N. ${ }^{\circ}$ : CNE/CEB 35/2003, p.43)

Vemos no item I que o Estágio Profissional Obrigatório é orientado para cursos de perfis profissionais que possuem exigências decorrentes da própria natureza da habilitação ou qualificação profissional. Entendemos então que seria uma modalidade de estágio adequada as instituições ofertantes de cursos que conferem ao aluno habilitação profissional específica como é o caso do ensino integrado.

O item II, Estágio Profissional "Não Obrigatório", por ser opcional como define a Lei 11.788 e não pela "não obrigação" como sugere o nome; nos parece ser mais adequado às instituições que promovem o ensino médio regular, uma vez que não é dever dessas instituições fornecer habilitação profissional específica, e também, como é sabido, geralmente elas não possuem infraestrutura adequada para isso. Talvez por isso a Lei 11.788/08, em referência a realidade dessas instituições, que não tem a especificidade da profissionalização e tampouco a infraestrutura adequada, tenha acrescentado a opcionalidade nessa modalidade de estágio, deixando-a de livre 
escolha do aluno. O Interessante dessa modalidade é que possibilita o estagiário ser remunerado, diferentemente do estágio obrigatório.

Outra observação que se faz nesse momento, e que será importante mais adiante, é que o estágio de categoria "não obrigatório" pode coexistir com a categoria "obrigatória", pois como vimos no item II do artigo $5^{\circ}$ do PARECER N..: CNE/CEB 35/2003 as duas modalidades "são modalidades de estágio curricular supervisionado, a serem incluídas no projeto pedagógico da Instituição de Ensino e no planejamento curricular do curso, como ato educativo", e ainda no item II, o estágio de modalidade "não obrigatório" deverá ser realizado pelos alunos se "incluído no respectivo plano de curso, o que o torna obrigatório para os seus alunos, mantendo coerência com o perfil profissional de conclusão do curso" (PARECER N.': CNE/CEB 35/2003). Ou seja, mesmo sendo o estágio de categoria "não obrigatório", estando no projeto pedagógico da Instituição e no planejamento curricular do curso, deverá ser ministrado e desenvolvido pelo aluno, que assim escolher, com a devida carga horária e acompanhamento a fim de conferir validade ao curso.

Encontramos no estudo do CNE/UNESCO (s.d.) esse mesmo entendimento do SENAC SP (Serviço Nacional de Aprendizagem Comercial de São Paulo) acerca do estágio de categoria "não obrigatório" como componente curricular.

Um exemplo das considerações mencionadas acima é a compreensão do SENAC SP acerca do estágio supervisionado e o ATO EDUCATIVO:

Estágio é o conjunto de atividades desenvolvidas no ambiente laboral, que visa à preparação do estudante para o trabalho em sua área de formação, integrando a aprendizagem social, profissional e cultural. Obrigatório ou não obrigatório constitui-se como componente curricular, um vínculo educativo profissionalizante que se fundamenta no compromisso formal entre o estagiário (aluno), o Senac São Paulo e a empresa ou organização, com base no Plano de Curso. Neste sentido, o ambiente laboral converte-se em espaço de ensino aprendizagem, mediado, ainda, pela orientação docente, redimensionando o exercício da prática.

[continua] 
Analisados à luz das referências teóricas construídas ao longo do curso, os desafios do dia a dia se transformam em novas possibilidades de construção do conhecimento. O ambiente laboral, portanto, enriquece e atualiza a formação do aluno não apenas no que diz respeito às competências técnicas, como também às atitudinais. (CNE/UNESCO, Produto 1, p.52, grifo nosso).

Enfim, de fato, como declarou o Parecer N. .: CNE/CEB 35/2003 no início de seu texto, o tema é polêmico e controverso, mas verifica-se que também é um tanto confuso, principalmente quanto a sua obrigatoriedade. Diante disso, o que se espera, utilizando à lógica e o bom senso, principalmente, e mais especificamente quanto às instituições profissionalizantes, é que sempre deverá ser feito alguma modalidade de estágio pelos discentes, seja ela com as características do "obrigatório" ou com as características do "não obrigatório", uma vez que essas instituições formarão profissionais específicos para o mercado de trabalho, diferentemente das outras instituições de ensino, que embora o tema também abranja, não possuem o objetivo e a obrigatoriedade da habilitação profissional. Deixemos a opcionalidade do estágio supervisionado que trata a Lei 11.788/08 para as instituições de ensino médio regular e ensino médio especial.

\subsubsection{A Questão da Duração e Carga Horária}

Como vimos o Parecer CNE/CEB N.: 35/2003 informa que a modalidade Educação Profissional nele contemplada está no seu sentido mais amplo, ou seja, nos níveis Básico, Técnico e Tecnológico.

No Parecer CNE/CEB N.: 35/2003 não se encontra alguma discussão sobre o limite mínimo de carga horária de estágio supervisionado para cursos de nível técnico, no entanto, encontra-se uma referência para cursos de nível básico: 
A modalidade Educação Profissional é aqui contemplada no seu sentido mais amplo, da maneira como é tratada pela LDB (Lei Federal $n^{\circ}$ 9394/96) e também pelo Decreto $n^{\circ} 2208 / 97$, isto é, nos níveis Básico, Técnico e Tecnológico.

$[\ldots]$

O chamado nível básico da educação profissional também contempla cursos que exigem oportunidades de prática profissional para alem das salas ambiente e dos laboratórios de aprendizagem, necessitando uma prática profissional integrada na realidade do mundo do trabalho. É a situação que algumas instituições de educação profissional costumam caracterizar como "estações de vivência do trabalho". É claro que esse estágio profissional supervisionado só pode ser planejado para alunos de cursos de maior duração e de maior densidade curricular. Uma carga horária mínima da ordem de 150 horas para esses cursos pode ser um bom referencial. (CNE/CEB N. ${ }^{0}:$ 35/2003, p.6)

Atentemos as 150 horas de carga horária mínima para o estágio supervisionado no nível básico. O nível básico que o CNE/CEB N. : 35/2003 se refere de acordo como é tratado no Decreto $n^{\circ} 2.208 / 97$ era destinado "à qualificação, requalificação e reprofissionalização de trabalhadores, independente de escolaridade prévia", ou seja, cursos de curta duração.

níveis:

Art3 ${ }^{\circ} \mathrm{A}$ educação profissional compreende os seguintes

I - básico: destinado à qualificação, requalificação e reprofissionalização de trabalhadores, independente de escolaridade prévia;

II - técnico: destinado a proporcionar habilitação profissional a alunos matriculados ou egressos do ensino médio, devendo ser ministrado na forma estabelecida por este Decreto;

III - tecnológico: correspondente a cursos de nível superior na área tecnológica, destinados a egressos do ensino médio e técnico. (DECRETO n².208/97)

De acordo com a Resolução No 1, de 3 de Fevereiro de 2005, que atualizou as Diretrizes Curriculares Nacionais definidas pelo Conselho Nacional de Educação para o Ensino Médio e para a Educação Profissional Técnica de nível médio às disposições do Decreto $n^{\circ} 5.154 / 2004$ (que revogou o decreto 2.208/97), o nível básico passa a outra denominação: 
Art. $3^{\circ} \mathrm{A}$ nomenclatura dos cursos e programas de Educação Profissional passará a ser atualizada nos seguintes termos:

\section{"Educação Profissional de nível básico" passa a denominar-se "formação inicial e continuada de trabalhadores";}

"Educação Profissional de nível técnico" passa a denominar-se "Educação Profissional Técnica de nível médio";

"Educação Profissional de nível tecnológico" passa a denominar-se "Educação Profissional Tecnológica, de graduação e de pós-graduação". (RESOLUÇÃO № 1, de 3 de Fevereiro de 2005, grifo nosso).

O que queremos salientar aqui são as 150 horas de estágio supervisionado recomendadas para cursos de curta duração como são os cursos de formação inicial e continuada de trabalhadores, tendo então essa referência, inferimos que cursos de maior duração, como por exemplo cursos técnicos integrados que possuem no mínimo 3.000 horas, deverão ter uma carga horária de estágio supervisionado maior que apenas 150 horas.

O Parecer CNE/CEB N.: 35/2003, homologado, publicado no Diário Oficial da União de 20/1/2004, estabelecendo as Diretrizes Nacionais para a organização e a realização de Estágio de alunos da Educação Profissional e do Ensino Médio, inclusive nas modalidades de Educação Especial e de Educação de Jovens e Adultos, resolveu:

Artigo $7^{\circ}$ A carga horária, duração e jornada do estágio, a serem cumpridas pelo estagiário, devem ser compatíveis com a jornada escolar do aluno, definidas de comum acordo entre a Instituição de Ensino, a parte concedente de estágio e o estagiário ou seu representante legal, de forma a não prejudicar suas atividades escolares, respeitada a legislação em vigor.

$\S 1^{\circ} \mathrm{A}$ carga horária do estágio profissional supervisionado não poderá exceder a jornada diária de 6 horas, perfazendo 30 horas semanais. (CNE/CEB N. .: 35/2003, p. 44)

Vimos acima que o Parecer CNE/CEB N.": 35/2003 informa que "a carga horária, duração e jornada do estágio, a serem cumpridas pelo estagiário, devem ser compatíveis com a jornada escolar do aluno" e também que para os cursos de 
formação inicial e continuada "uma carga horária mínima da ordem de 150 horas para esses cursos pode ser um bom referencial".

A cartilha de projetos e ações da SETEC traz as definições da Portaria Interministerial $n^{\circ}$ 1.082, DE 20 de Novembro DE 2009 que dispõe sobre a criação da Rede Nacional de Certificação Profissional e Formação Inicial e Continuada - Rede CERTIFIC, informando que:

Os cursos de formação inicial e continuada, dirigidos aos trabalhadores jovens e adultos, têm carga horária máxima de 1.600 horas, das quais, no mínimo, 1.200 horas são para a formação geral e 200 horas para a formação profissional. (SETEC, 2010, p.19)

Quanto ao ensino técnico integrado ao ensino médio, podemos verificar no Art. 27, capítulo III da Resolução № 6, de 20 de Setembro de 2012 (que define as diretrizes curriculares nacionais para a Educação Profissional Técnica de Nível Médio) que a carga horária de um curso técnico integrado ao ensino médio tem no mínimo 3.000 horas, portanto tem 1.400 horas a mais do que a maior carga horária de um curso de formação inicial e continuada:

Art. 27 Os cursos de Educação Profissional Técnica de Nível Médio, na forma articulada com o Ensino Médio, integrada ou concomitante em instituições de ensino distintas com projeto pedagógico unificado, têm as cargas horárias totais de, no mínimo, $3.000,3.100$ ou 3.200 horas, conforme o número de horas para as respectivas habilitações profissionais indicadas no Catálogo Nacional de Cursos Técnicos, seja de 800, 1.000 ou 1.200 horas. (RESOLUÇÃO Nº 6, DE 20 DE SETEMBRO DE 2012, p.8)

Portanto, podendo existir no mínimo 1.400 horas a mais em cursos Técnicos Integrados de Nível Médio em relação a um curso FIC (Formação Inicial e Continuada de Trabalhadores), é fácil deduzir que no primeiro deveremos ter uma carga horária bem superior a 150 horas, para se mostrar compatível "com a jornada escolar do aluno". 
Coerente com as informações acima relatadas, o Parecer CNE/CEB N.o: 35/2003, momento antes da resolução, explanando a relação entre o estágio supervisionado e o mundo trabalho mencionou que:

No Serviço Público Federal, a "aceitação, como estagiários, de alunos regularmente matriculados e que venham frequentando, efetivamente, cursos de educação superior, de ensino médio e de educação profissional", é regulamentada, atualmente, pela Portaria 08/01, de 23/01/01, do Ministro do Planejamento, Orçamento e Gestão, o qual dispõe, em síntese, o seguinte:

\section{$[\ldots]$}

d) carga horária semanal de, no mínimo, vinte horas, distribuída nos horários de funcionamento do órgão ou entidade e compatível com o horário escolar;

e) duração do estágio, obedecido o período mínimo de um semestre e o máximo de quatro;(PARECER CNE/CEB N..: 35/2003, p.12, grifo nosso)

O termo de convênio do serviço público federal, por exemplo, tendo como período mínimo de um semestre e com uma carga horária semanal de, no mínimo, vinte horas, ao se contabilizar 20 semanas no semestre, teremos 400 horas de estágio supervisionado.

Portanto, configura-se ainda mais o entendimento que uma carga horária compatível com a jornada escolar do aluno do ensino de nível médio técnico integrado deva ser superior a 150 horas.

A atual lei do Estágio possibilita implementar uma carga horária de estágio coerente com a duração dos cursos da educação profissional integrada ao ensino médio ao definir:

Art. 10. A jornada de atividade em estágio será definida de comum acordo entre a instituição de ensino, a parte concedente e o aluno estagiário ou seu representante legal, devendo constar do termo de compromisso ser compatível com as atividades escolares e não ultrapassar:

[continua] 


\begin{abstract}
$[.$.
II - 6 (seis) horas diárias e $\mathbf{3 0}$ (trinta) horas semanais, no caso de estudantes do ensino superior, da educação profissional de nível médio e do ensino médio regular. (LEI No 11.788, DE 25 DE SETEMBRO DE 2008, grifo nosso)
\end{abstract}

Logo, se contabilizarmos as seis horas diárias de apenas um semestre, teríamos uma carga horária superior às 400 horas calculadas anteriormente, evidenciando ainda mais que valores próximos a 400 horas, ou até mesmo significativamente superiores, são mais condizentes com a carga horária de cursos Técnicos Integrados de Nível Médio.

No sítio da Secretaria da Educação do Rio Grande do Sul é disponibilizado uma "Proposta Pedagógica Para O Ensino Médio Politécnico E Educação Profissional Integrada Ao Ensino Médio" onde encontramos uma recomendação para a carga horária destinada ao estágio supervisionado com valor igual ao que contabilizamos.

Considerando a perspectiva do currículo integrado - onde não há dissociação entre teoria e prática - o estágio supervisionado não pode se configurar como um momento distinto do curso, mas sim como uma etapa, na qual os alunos poderão articular o conhecimento teórico e, a partir de hipóteses, responder às demandas que se apresentam no exercício da profissão. A duração do estágio supervisionado deverá ser acrescida ao mínimo estabelecido para o curso (Parecer CNE/CEB $n^{\circ} 16 / 99$ e art. $9^{\circ}$ da Resolução CNE/CEB n 4/99). Está prevista para cursos com menos de 1.200h uma carga horária mínima para o estágio de 200h; para cursos com 1.200h ou mais, está prevista uma carga horária mínima de 400h (Resolução CEED n² 279/2004), Lei Federal $n^{\circ}$ 11.788/2008; Resolução $n^{\circ}$ 279/2004 CEED/RS - Estabelece normas para a organização de estágio de alunos da Educação Profissional Técnica de Nível Médio. (SECRETARIA DA EDUCAÇÃO DO RIO GRANDE DO SUL)

A questão discutida até o momento, a carga horária do estágio supervisionado, se torna importante porque será que 80,150 ou até mesmo 200 horas, por exemplo, nos cursos técnicos integrados ao ensino médio, são suficientes para contemplar o conceito de estágio presente na atual Lei de Estágio 11.788/08 vista no início deste capítulo? A pesquisa de campo apontou que 150 horas de estágio supervisionado não foram suficientes, nem mesmo se fosse levar em conta somente a contextualização curricular, sendo perceptível essa insuficiência até mesmo para os discentes. 
O Parecer CNE/CP n 28 , de 2 de outubro de 2001 que dá nova redação ao Parecer CNE/CP 21/2001, embora trate da duração e a carga horária dos cursos de Formação de Professores, traz pertinente discussão e esclarecimento acerca do estágio supervisionado, como por exemplo, a distinção entre Prática e Estágio Supervisionado, que também encontramos na Resolução CNE/CEB n. ${ }^{\circ} 1$, de 21 de janeiro de 2004, em seu Art. $12 \S 1^{\circ}$ e no PARECER N.': CNE/CEB 35/2003 já discutido nesse documento ("praticagem profissional"), e ainda enfatiza que deve haver tempo e espaço para a prática.

A prática não é uma cópia da teoria e nem esta é um reflexo daquela. A prática é o próprio modo como as coisas vão sendo feitas cujo conteúdo é atravessado por uma teoria. Assim a realidade é um movimento constituído pela prática e pela teoria como momentos de um dever mais amplo, consistindo a prática no momento pelo qual se busca fazer algo, produzir alguma coisa e que a teoria procura conceituar, significar e com isto administrar o campo e o sentido desta atuação.

"Uma concepção de prática mais como componente curricular implica vê-la como uma dimensão do conhecimento, que tanto está presente nos cursos de formação nos momentos em que se trabalha na reflexão sobre a atividade profissional, como durante o estágio nos momentos em que se exercita a atividade profissional. " (Parecer CNE/CP 9/2001, p. 22)

Assim, há que se distinguir, de um lado, a prática como componente curricular e, de outro, a prática de ensino e o estágio obrigatório definidos em lei. A primeira é mais abrangente: contempla os dispositivos legais e vai além deles. [...]

É fundamental que haja tempo e espaço para a prática, como componente curricular, desde o início do curso e que haja uma supervisão da instituição formadora como forma de apoio até mesmo à vista de uma avaliação de qualidade. (PARECER $\mathrm{CNE} / \mathrm{CP}^{\circ} 28$, p. 9, grifo nosso)

\subsection{Demais Orientações}

Tendo esclarecido as duas principais orientações para o estágio supervisionado nos cursos integrados (Obrigatoriedade e Carga Horária) abaixo listaremos as demais orientações para Implementação e Execução do Estágio Supervisionado a serem observadas pelo IFNMG. 


\subsubsection{Esclarecimento da Importância do Estágio Supervisionado ao Estudante e Acesso a Documentação Regulatória}

Divulgar e esclarecer devidamente o assunto estágio supervisionado, principalmente fazendo-a também na divulgação dos cursos integrados, pois dessa forma acreditamos que o público melhor visualizará os propósitos do ensino integrado, uma vez que geralmente ao deixar o ensino fundamental os alunos pouco sabem sobre a modalidade integrada. Assim sendo, acreditamos que público interessado em ingressar na instituição possa melhor compreender as finalidades da modalidade integrada e analisar melhor a sua escolha.

\subsubsection{Período de realização do estágio}

Evitar que os alunos do ensino integrado estagiem durante os recessos escolares, logo sem o devido acompanhamento efetivo do professor orientador como decreta a Lei, além de outros possíveis problemas já discutidos no capítulo 2. Essa situação só poderia ser corrigida com o aumento da duração do curso para mais de três anos, viabilizando a execução do estágio em período concomitante ao período regular de aulas, e dessa forma, melhor articulando a teoria com a prática.

\subsubsection{Acompanhamento do estagiário pelo professor orientador}

É necessário atentar como vem sendo executado o acompanhamento efetivo do professor orientador como preconiza a Lei 11.788/08, o ato de apenas assinar relatórios de estágio não pode ser considerado como acompanhamento efetivo. 


\subsubsection{Momento de Compartilhamento de Saberes dos Estagiários}

Além de ser um momento onde os estagiários possam compartilhar as experiências vividas entre eles, enriquecendo-se mutuamente, esse compartilhamento de saberes se promovido e acompanhado pela Instituição de ensino será uma excelente ferramenta para analisar e autocriticar o próprio curso, pois através desses momentos poderá perceber como se dá a atividade na concedente, e caso seja constatado algum tipo de deficiência na formação acadêmica, poderá servir de base para uma mudança no conteúdo curricular, seja incluindo novos componentes curriculares ou atualizando os já existentes.

Abaixo listamos algumas formas como os saberes são compartilhados em instituições de ensino levantados pela pesquisa de CNE/UNESCO (s.d.) e que podem servir de discussão para implementação no ensino integrado:

"Por meio de reuniões pedagógicas nas coordenações dos cursos". (IFTO)

"Seminário de Estágio Supervisionado. " (IFRJ) (CNE/UNESCO Produto 3, s.d, p.53)

\section{$[\ldots]$}

"Por meio de relato de experiências e discussão de casos compartilhados.". (Senac - SP/Cursos Técnicos)

"Os estagiários vivenciam situações de aprendizagem que antes não fora experimentada em sala de aula e as discutem nos próximos componentes curriculares."(Senac - AM)

"Através da interdisciplinaridade e transversalidade assegurada no Projeto Político Pedagógico, na organização curricular e na prática pedagógica dos docentes, visando à superação da fragmentação de conhecimentos.". (Senac - PR)

"Por meio de relatos de experiências entre os estudantes e da articulação da teoria e prática. " (Senac - CE) (CNE/UNESCO Produto 3, s.d, p.72)

[continua] 
$[\ldots]$

"Por meio de reuniões pedagógicas e técnicas, avaliação institucional e de curso. " (Senai - SP)

"Em projetos integradores e no trabalho de conclusão do curso.". (SENAI - BA/CIMATEC)

(CNE/UNESCO Produto 3, s.d., p.92, aspas do original).

\subsubsection{Desenvolvimento do Estágio em Ambiente Laboral Real}

É imprescindível que o estágio supervisionado seja realizado no ambiente real de trabalho e que a simulação feita na Instituição seja um complemento, uma preparação.

\subsubsection{Inclusão do Estágio Não Obrigatório Como Componente Curricular}

Tratar a categoria de "estágio não obrigatório" como componente curricular e não como opção curricular, sendo então uma alternativa ao discente a categoria de "estágio obrigatório", isso daria a oportunidade de remuneração dos estagiários pelas concedentes. 


\section{CONSIDERAÇÕES FINAIS}

A experiência do ensino integrado do passado e a atual nos revela que a escassez de um ensino médio de qualidade no Brasil torna interessante ingressar nas Instituições Federais Profissionalizantes apenas para se ter um ensino propedêutico de qualidade para um melhor preparo na disputa das vagas no ensino superior, dificultando essas Instituições de produzirem resultados na sua missão profissionalizante, pois não consegue atender a clientela que além do ensino propedêutico também deseja ou necessita da habilitação profissional.

A situação se agrava quando se implementa um ensino integrado de apenas três anos, como vimos, além de ser mais interessante àqueles que desejam concluir o ensino integrado no mesmo tempo do ensino médio regular, isso gera demasiada concentração da carga horária sobre os discentes, e como a grande maioria não se interessa pela profissionalização, é esse eixo a ser sacrificado, e o componente curricular mais frágil dessa relação, que os estudos indicaram, é o estágio supervisionado.

O Estágio Supervisionado acaba sendo implementado no que resta de carga horária por não existir uma definição clara, objetiva de qual deva ser sua carga horária no ensino profissionalizante, e como também não existe uma definição clara, objetiva da importância do estágio no ensino integrado, diferenciando-o do ensino médio regular, por exemplo, o estágio pode até mesmo ser suprimido de vez com a opcionalidade, e quando isso acontece a perda do caráter profissionalizante da política pública (que já é grave devido o pouco interesse dos discentes em atuar como técnico de nível médio) acentua-se a ponto de não formar profissionais devidamente preparados para o mundo do trabalho e nem mesmo de contribuir para a continuidade dos estudos na mesma área de formação técnica, consolidando o desperdício dos investimentos da parte profissionalizante em todos os aspectos.

É necessário resgatar o caráter profissionalizante da política pública do ensino integrado, do contrário o que diferenciaria as Instituições Federais Profissionalizantes das Instituições Particulares de Ensino Médio que tem como maior objetivo o foco no vestibular dos cursos superiores? 
No Brasil a maioria dos cidadãos não prossegue os estudos em nível superior, e atuam profissionalmente com um nível de escolarização que não ultrapassa a educação básica, essa classe não consegue adentrar nas Instituições Federais Profissionalizantes para cursar o ensino integrado, a concorrência é muito elevada, e, portanto, ficam sem a habilitação profissional e também sem um ensino propedêutico de qualidade, minando suas perspectivas de mudança na vida, decretando ainda mais o seu ciclo de pobreza.

Se as Instituições Federais Profissionalizantes não atuarem na mudança dessa realidade quem a fará? O que objetiva o ensino integrado e o que de fato estamos alcançando? Se não atentarmos para os resultados que estamos obtendo com o ensino integrado fatalmente produziremos resultados pouco eficientes em relação aos objetivos da política pública, e estaremos perdendo uma grande oportunidade de superar a dicotomia trabalho manual versus trabalho intelectual, e de incorporar a dimensão intelectual ao trabalho produtivo, para a formação de trabalhadores capazes de atuar como dirigentes e cidadãos, como descreveu Ciavatta (2005) ao referenciar Gramsci (1981).

Portanto, ficamos esperançosos que o estudo realizado nessa dissertação e em especial as Orientações do Produto Técnico, possa colaborar com as discussões e implementação acerca do estágio supervisionado nas Instituições Federais Profissionalizantes que ofertam o ensino integrado, no intuito de valorizar e consolidar esse importante componente curricular caracterizador do eixo profissionalizante, para que de fato o caráter profissionalizante que a política pública incorpora faça parte da identidade das Instituições e de seus Discentes, e assim, balanceando os resultados do ensino integrado aos objetivos da política pública. 


\section{REFERÊNCIAS BIBLIOGRÁFICAS}

ANJOS, Hellen Vivian Moreira dos. A opção pelo ensino médio integrado: o caso dos alunos do Instituto Federal de Educação, Ciência e Tecnologia do Norte de Minas Gerais - Campus Salinas. 2013. 146 f.Dissertação (Mestrado em Educação) Universidade de Brasília, Brasília-DF.

BARACHO, M. das G.; MOURA, D. H.; PEREIRA, U. Á.; SILVA, A, F.da. Algumas reflexões e proposições acerca do Ensino Médio Integrado à Educação Profissional Técnica de Nível Médio. In: Ensino Médio integrado à educação profissional: integrar para quê? Brasília: Ministério da Educação, Secretaria de Educação Básica, 2006. Disponível em:<portal.mec.gov.br/setec/arquivos/pdf2/boleti m_salto07.pdf> Acesso em: 06 Jul. 2014.

BARDIN, Laurence. Análise de conteúdo. São Paulo: Edições 70, 2011, 229 p.

BRASIL. Decreto n 5.154 de 23 de Julho de 2004. Brasília 23 de Julho de 2004. Disponível em: <http://www.planalto.gov.br/ccivil_03/_ato20042006/2004/decreto/d5 154.htm> Acesso em: 07 Mai. 2014.

Lei $\mathrm{n}^{\circ}$ 11.892, de 29 de dezembro de 2008. Institui a Rede Federal de Educação Profissional, Científica e Tecnológica, cria os Institutos Federais de Educação, Ciência e Tecnologia, e dá outras providências. Disponível em: http://www.planalto.gov.br/ccivil 03/ ato2007-2010/2008/lei//11892.htm. Acesso em 09 Mai. 2015.

.Lei n. 5.692/71, de 11 de agosto de 1971. Fixa Diretrizes e Bases para o ensino de $1^{\circ}$ e $2^{\circ}$ graus, e dá outras providências. Brasília, DF: 11 de agosto de 1971.Disponível em:<www.planalto.gov.br/ccivil 03/Leis/L5692.htm>. Acesso em: 01 Mai. 2015.

.Documento Base da Educação Profissional Técnica de Nível Médio Inte grada ao Ensino Médio. Disponível em: http://portal.mec.gov.br/setec/arquivos/pdf/ documento base.pdf. Acesso 07 Mai. 2014.

.Decreto $N^{\circ} 2.208 / 04$. Regulamenta o $\S 2^{\circ}$ do art. 36 e os arts. 39 a 42 da Lei $\overline{n^{\circ} 9.394}$, de 20 de dezembro de 1996, que estabelece as diretrizes e bases da educação nacional.Disponível em: http://www.planalto.gov.br/ccivil 03/decreto/D220 8.htm>.Acesso em: 07 Mai. de 2014.

. Lei $\mathbf{n}^{\circ} \mathbf{7 . 0 4 4}$ de 18 de outubro de 1982. Altera dispositivos da Lei 5692/71, referentes à profissionalização do ensino de $2^{\circ} \mathrm{Grau}$. Brasília/DF: Subsecretaria de Informações. Disponível em:<www.planalto.gov.br/ccivil 03/Leis/L7044.htm>.Acesso em: 01/02/2014.

.Tribunal de Contas da União.Relatório de Auditoria. Rede Federal de Educação Profissional, Científica e Tecnológica. Brasília/DF, junho de 2012. Disponívelem:<http://portal2.tcu.gov.br/portal/page/portal/TCU/comunidades/program 
as governo/areas atuacao/educacao/Relatorio $\% 20 \mathrm{de} \% 20$ Auditoria $\% 20 \% 20$ Educac ao\%20Profissional.pdf>. Acesso em: 23 Out. 2014.

Ministério da Educação. Projeto CNE/UNESCO 914BRZ1136.3 "Desenvolvimento, aprimoramento e consolidação de uma educação nacional de qualidade". CNE. Brasília, 2013. Disponível em: <http://portal.mec.gov.br/index.p hp?option=com_docman\&task>.. Acesso em 24 Fev. 2015.

.MEC/Conselho Nacional de Educação. Câmara de Educação Básica.Parecer n.35/2003 de 05 de Novembro de 2003. Brasília, 2003 Disponível em: <portal.mec.gov.br/cne/arquivos/pdf/pceb35_03.pdf>. Acesso em 14 Mar. 2014.

. Ministério da Educação. INSTITUTO FEDERAL DE EDUCAÇÃO, CIÊNCIA E TECNOLOGIA. Um novo modelo em Educação Profissional e Tecnológica. Concepção e Diretrizes. Brasília: SETEC/MEC, 2010. Disponível em:<http://portal.mec.gov.br/index.php?option=com_docman\&view=download\&alias =6691-if-concepcaoediretrizes\&category_slug=setembro-2010-pdf\&ltemid=30192 > Acesso em: 28 Jan. 2014.

SETEC. Educação Profissional e Tecnológica Projeos e Ações 2010 Brasília: $\quad$ SETEC/MEC, 2010.2 Disponível em:<http://portal.mec.gov.br/index.php?option=com_docman\&view=download\&alias =7417-cartilha-projetos-acoes-setec-web\&category_slug=janeiro-2011pdf\&ltemid=30192> Acesso em: 22 Jan. 2014.

.Lei de Diretrizes e Bases da Educação Nacional: $n^{\circ}$ 9394/96. Brasília : 1996. Brasília: MEC, 1996. Disponível em:<portal.mec.gov.br/arquivos/pdf/ldb.pdf> Acesso em: 27 Jan. 2014.

BURIOLLA, Marta Alice Feiten. O Estágio Supervisionado. São Paulo: Cortez, 2001.

CAMPELLO, Ana Margarida de Mello Barreto; LIMA FILHO, Domingos Leite. Educação Profissional. Dicionário da Educação Profissional em Saúde. Org: Escola Politécnica de Saúde Joaquim Venâncio e Estação de Trabalho Observatório de técnicos em Saúde. Rio de janeiro: EPSJV, 2006.

CARVALHO, Olgamir Francisco de. Educação e formação profissional - trabalho e tempo livre. Brasília: Plano, 2003.

CASTRO, Claudio de Moura. Educação técnica: a crônica de um casamento turbulento. In: SCHWARTZMAN, Simon; BROCK, Colin (Orgs.). Os desafios da educação no Brasil. Rio de Janeiro: Nova Fronteira, 2005. p. 153-180.

CASTRO, Claudio de Moura. Oficinas mecânicas para formar advogados? Veja, n.1520, p.142, nov.1997. Disponível em:<http://veja.abril.com.br/acervodigital/home.aspx>. Acesso em: 12 de Mai. de 2015 
CAVALCANTE, G. C.. Memória e História de Vida: Uma Questão de Identidade. In: CUNHA, Gregório Maranguape da (Org.). Estágio nos Cursos Tecnológicos: Conhecendo a Profissão e o Profissional. Fortaleza: Edições UFC, 2006.

CIAVATTA, Maria. A formação integrada: a escola e o trabalho como lugares de memória e de identidade. IN: Frigotto, Gaudêncio, Ciavatta, Maria; Ramos, Marise (orgs). Ensino médio integrado: concepções e contradições. São Paulo: Cortez, 2005. p. 83-105.

COSTA NETO, O.; GONÇALVES, H. H. A Construção e a socialização do conhecimento. In: CUNHA, G. M. da; HOLANDA, P. H. C.; VASCONCELOS, C. L. de. (Orgs.). Estágio Supervisionado: questões da prática profissional. Fortaleza: UFC, 2007.

CRESWELL, John W. Projeto de pesquisa: métodos qualitativo, quantitativo e misto. Porto Alegre: Artmed, 2007

CRUZ NETO, O..O Trabalho De Campo Como Descoberta E Criação. In:

(Org.) Pesquisa Social: Teoria, Método e Criatividade. 14. ed. Ed. Vozes; Petrópolis, 1999.

FARIA, Cláudio Miguel Alves De. Estágio Curricular Supervisionado: A Contribuição Para A Formação Profissional Do Técnico Agrícola No Instituto Federal De Minas Gerais Campus De Bambuí. Dissertação de Mestrado, UFRRJ, 2009.

FIEP. Indústria precisará de 7,2 milhões de técnicos até 2015, indica estudo do SENAI. Disponível em:<http://www.agenciafiep.com.br/noticia/industria-precisara-de72-milhoes-de-tecnicos-ate-2015-indica-estudo-do-senai/>.Acesso em: 14nov. 2014.

FLICK, Uwe. Introdução à metodologia de pesquisa: um guia para iniciantes. Porto Alegre. Ed Penso, 2013.

FONSECA; R. T. M.da. AS FORMAS DE APRENDIZAGEM NO BRASIL: QUESTÕES EMERGENTES. Rev. TST, Brasília, vol. 79, no 1, jan/mar 2013. Disponível em:http://aplicacao.tst.jus.br/dspace/bitstream/handle/1939/38660/0 09_fonseca.pdf?sequence=1. Acesso em: 03 Mar. 2015.

FRIGOTTO, Gaudêncio; CIAVATTA, Maria. A gênese do Decreto n. 5.154/2004: um debate no contexto controverso da democracia restrita.Boletim 07 , maio/junho 2006.Programa 2: CONCEPÇÃO E EXPERIÊNCIAS DE ENSINO INTEGRADO. Ministério da Educação. Secretaria de Educação a Distância. TV Escola. Salto para o Futuro. Disponível em:http://portal.mec.gov.br/setec/arquivos/pd f2/boletim salto07.pdf. Acesso em: 28 abr. 2015.

IDH. Índice de Desenvolvimento Humano Januária. [online] Disponível na Internet via WWW. URL: http://www.cdljanuaria.com.br/page/apres p.pdf. Arquivo capturado em 05 Abr. 2015. 
IFNMG - Instituto Federal do Norte de Minas Gerais - Histórico do Campus Januária. [online] Disponível na Internet via WWW. URL:http://www.ifnmg.edu.br/mai s-noticias?id=499. Arquivo capturado em 03 Mar. 2014.

IFNMG. Regulamento Dos Cursos De Educação Profissional Técnica De Nível Médio Do Instituto Federal Do Norte De Minas Gerais (Ifnmg) 2013. Disponível em: $<$ http://documento.ifnmg.edu.br/action.php?kt path info=ktcore.actions.documen t.view\&fDocumentld=11814> Acesso em: 23 Mai. 2015.

IFNMG. Regulamento Para Estágios De Discentes Do Instituto Federal De Educação, Ciência E Tecnologia Do Norte De Minas Gerais.Disponível em: $<$ http://documento.ifnmg.edu.br/action.php?kt path info=ktcore.actions.documet.vie w\&fDocumentld=3506>.Acesso em: 23 Mai. 2015.

IFNMG.Projeto de curso: curso técnico em informáticalntegrado ao ensino médio. Januária 2012. Disponível em:<http://documento.ifnmg.edu.br/action.php?kt path info=ktcore.actions.document.view\&fDocumentld=3679>. Acesso em: 09 Jul. 2015.

INEP. A profissionalização do ensino na lei 5692/71. Trabalho apresentado pelo INEP para XVIII Reunião do Conselho Federal de Educação com os Conselhos Estaduais de Educação. Brasília: 1982.

JESUS, Edilson Rosa Barbosa de; JESUS, Valéria Tomi Kamijo de Moraes. Perfil dos alunos ingressantes no ano de 2013 nos cursos técnicos integrados e concomitante do ifsp - Bragança Paulista. Revista lluminart, Revista Científica eletrônica, ano vi, IFSP - CAMPUS SERTÃOZINHO, MARÇO / 2014.

KRÜGER, Elbert; TAMBARA, Elomar. O resgate histórico da função social da educação profissional brasileira, à luz dos decretos 7.566/1909 e 2.208/1997: um estudo do perfil dos alunos do Cefet-RS. IV Congresso Brasileiro da História da Educação, Goiânia,05-08 novembro, 2006. Disponível em:

<http://www.sbhe.org.br/novo/congressos/cbhe4/individuaiscoautorais/eixo01/Edelbe rt\%20Kruger\%20e\%20Elomar\%20Tambara\%20-\%20Texto.pdf>. Acesso em: 07 Mai. 2014.

KUENZER, Acácia Zeneida. O ensino médio para os que vivem do trabalho: formar para inclusão subordinada?. Disponível em:<http://www.learningace.com/ doc/4415935/72d5afa9265a02e28fac55a4acc1e14a/kuenzeracaciazeneida>. Acesso em: 01 Jul. 2015.

KUENZER, Acácia Zeneida (Org.). Ensino Médio: construindo uma proposta para os que vivem do trabalho. 2. ed. São Paulo: Cortez, 2001.

LAKATOS, Eva Maria; MARCONI, Marina de Andrade. Fundamentos de metodologia científica 1. - 5. ed. - São Paulo : Atlas 2003.

LIMA, M, S. L.; VASCONCELOS, C. L. de. O Lugar do Estágio nos Cursos de Graduação Tecnológica. In: CUNHA, Gregório Maranguape da (Org.). Estágio nos 
Cursos Tecnológicos: Conhecendo a Profissão e o Profissional. Fortaleza: Edições UFC, 2006.

PIMENTA, Selma Garrido; LIMA, Maria Socorro Lucena. Estágio e docência. Revisão técnica José Cerchi Fusari, São Paulo: Cortez, 2004. (Coleção docência em formação. Série saberes pedagógicos)

LOPONTE, Luciana Neves. Juventude e educação profissional: um estudo com os alunos do IFSP.Tesede Doutorado, PUC-SP, 2010.

MACÁRIO, Epitácio. Determinações ontológicas da educação: uma leitura à luz da categoria trabalho. In: REUNIÃO ANUAL DA ASSOCIAÇÃO NACIONAL DE PÓS-GRADUAÇÃO E PESQUISA EM EDUCAÇÃO, XXIV, 2001, Caxambu, MG. Anais eletrônicos.. Rio de Janeiro: Associação Nacional de Pós-Graduação e Pesquisa em Educação, 2001.

MOURA, Dante Henrique. Algumas possibilidades de organização do ensino médio a partir de uma base unitária: trabalho, ciência, tecnologia e cultura. In: Anais... I Seminário Nacional: currículo em movimento - Perspectivas Atuais Belo Horizonte, novembro de 2010.

NISKIER, Arnaldo; SOUZA, Paulo N. P. de. Educação, estágio e trabalho. São Paulo: Integrare Editora, 2006. 231 p.

PACHECO, Eliezer (org.). Os Institutos Federais: uma revolução na educação profissional e tecnológica. Brasília: MEC, 2011. Disponível em: . Acesso em: 26 mar. 2014.

PINTO, Marcelino Resende; AMARAL, Nelson Cardoso; CASTRO, Jorge Abrahão. 0 financiamento do ensino médio no Brasil: de uma escola boa para poucos à massificação barata da rede pública.Educação e Sociedade, Campinas, v. 32, n. 116, p. 639-665, jul./set.2011. Disponível em:

<http://www.scielo.br/pdf/es/v32n116/a03v32n116.pdf >. Acesso em: 07 mai. 2014.

PORTAL DA INDÚSTRIA.O que é o SENAI?. [online] Disponível na Internet via WWW. URL:<http://www.portaldaindustria.com.br/senai/institucional/2015/05/1,1773/ o-que-e-o-senai.html. Acesso em 04 Ago. 2015.

RODRIGUES, Fernando Morais. Evasão nos Cursos Técnicos em Informática Subsequente e Médio Integrado do Instituto Federal de Educação, Ciência e Tecnologia do Tocantins (IFTO) - Campus Paraíso no Período de 2007 a 2010 UnB. Brasília (DF):2011 Dissertação - Programa de Pós-Graduação em Educação.

SANTOS, Eliane Regina Acácio dos. A realidade do estágio supervisionado no ensino profissionalizante de nível médio: um estudo sobre o curso de Técnico Agrícola da Escola Agrotécnica Federal de Colorado do Oeste - RO. Brasília, 2009. Dissertação de mestrado-Faculdade de Educação Universidade de Brasília, 2009. 
SAVIANI, Dermeval. A pedagogia no Brasil: história e teoria. Campinas, São Paulo: Autores Associados, 2008.

SECRETARIA DA EDUCAÇÃO DO RIO GRANDE DO SUL. Proposta Pedagógica Para O Ensino Médio Politécnico E Educação Profissional Integrada Ao Ensino Médio - 2011-2014.2011, Porto Alegre. SENAI-Serviço Nacional de Aprendizagem Industrial. Regulamento de Estágio Supervisionado 2012. Disponível em:

http://www.sp.senai.br/portal/diadema/conteudo/regulamento\%20de\%20est $\%$ C3\%A1 gio\%202012-v04.doc. Acesso em: 23 Jul. 2015.

SILVA, Caetana Juracy (org.). Institutos Federais Lei 11.892, de 29/12/2008: Comentários e Reflexões. Natal: IFRN, 2009. Disponível em:http://portal.mec.gov.b r/index.php?option $=$ com docman\&task $=$ doc download\&gid=3753\&ltemid=. Acesso em 18 mar. 2013.

SPRATT, Christine; ROB Walker; ROBINSON Bernadette. Mixed research methods. Practitioner Research and Evaluation Skills Training in Open and Distance Learning.Commonwealthof Learning, 2004. Disponível em: http://www.col.org/SiteCollectionDocuments/A5.pdf. Acesso em: 10 mar. 2013.

VALASKI, Marli Klein. Ensino Médio Técnico Integrado no Paraná: formação e qualificação enquanto Política Pública. Dissertação de Mestrado, Universidade Federal do Paraná Curitiba,2012.Disponível em: http://www.humanas.ufpr.br/portal/ci enciassociais/files/2012/06/Monografia-Marli-K-Valaski.pdf. Acesso em: 07 de Mai. de 2014.

ZABALZA, Miguel Antonio. Qualidade em educação infantil. Tradução Beatriz Affonso Neves. Porto Alegre: Artmed, 1998. 


\section{APÊNDICES}

\section{Apêndice A: Questionário Pesquisa Quantitativa Discente - Agropecuária}

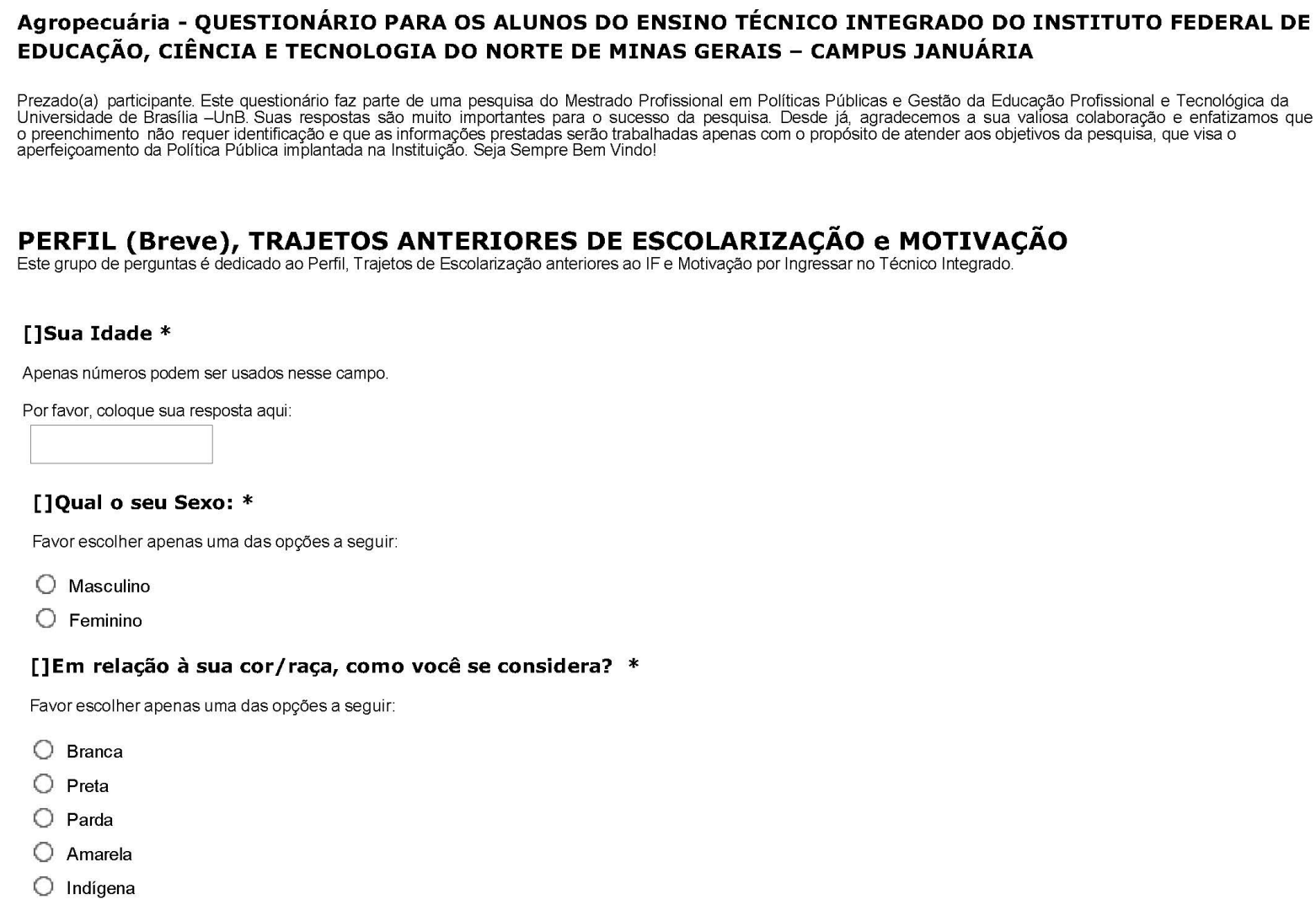

[]Qual ano você está cursando? Favor escolher apenas uma das opções a seguir: * Favor escolher apenas uma das opções a seguir:
( $1^{\circ}$ Ano
$2^{\circ}$ Ano
$3^{\circ}$ Ano

\section{[]Você é Aluno: *}

Favor escolher apenas uma das opções a seguir:

Interno

Semi-Interno

Externo

[]Em que tipo de escola você estudou no ensino fundamental: *

Favor escolher apenas uma das opções a seguir:

Somente em escola pública

Somente em escola particular

Parte em escola pública/parte em escola particular 
Dentre os FATORES QUE ESTIVERAM PRESENTES NA ESCOLHA PELO ENSINO INTEGRADO, responda o quanto cada um deles INFLUENCIOU sua decisão pelo curso: Utilize a legenda abaixo 1 = Muito Alto | 2 = Alto | 3 = Médio | 4 = Baixo | 5 = Muito Baixo | 6 = Irrelevante* Por favor, escolha a resposta adequada para cada item:

Escolhi o curso para dar prosseguimento aos meus estudos/fazer uma faculdade. Escolhi o curso porque pretendo entrar no mercado de trabalho assim que concluir.

Escolhi o curso porque meus pais/família incentivaram. Necessidade de obtenção de diploma de curso técnico. Necessidade de obtenção de diploma de ensino médio.

[]Em relação a sua necessidade de estudos você: *

Favor escolher apenas uma das opções a seguir:

Preferiria cursar SOMENTE o ensino MÉDIO no IFNMG

Preferiria cursar SOMENTE o ensino TÉCNICO no IFNMG.

Preferiria cursar o modelo atual: Curso Técnico e Médio ao mesmo tempo (INTEGRADO).

[]Se o IFNMG oferecesse SOMENTE o ENSINO MÉDIO, sem a obrigatoriedade de fazer o ensino Técnico, você se interessaria em cursar somente o ensino médio? *

Favor escolher apenas uma das opçōes a seguir:

$0 \operatorname{Sim}$

Não

Talvez

[]Se o IFNMG oferecesse SOMENTE o ENSINO TÉCNICO, sem a obrigatoriedade de fazer o ensino Médio, você se interessaria em cursar somente o ensino técnico? *

Favor escolher apenas uma das opções a seguir:

O Sim

Não

Talvez

[]Você faria o Ensino Integrado Cursando as Disciplinas Técnicas/Profissionalizantes no IFNMG e, AO MESMO TEMPO, o Ensino Médio em outra Instituição? *

Favor escolher apenas uma das opções a seguir:

Sim

Não 
Além dos conteúdos propostos pelo IFNMG-Januária, você costuma investir mais em assuntos/conhecimentos:

Indique um Grau de Interesse de 1 a 6 . Onde 1 é interesse Muito Alto e 6 é Irrelevante.

Por favor, escolha a resposta adequada para cada item:

$1=$ Muito Alto $2=$ Alto $\quad 3$ = Médio $\quad 4$ = Baixo $\quad 5=$ Muito Baixo $6=$ Irrelevante

Relacionados ao vestibular para

O

0

0

0

$\mathrm{O}$

Relacionados a Profissão do

curso técnico.

Clique num valor de 1 a 6

[]Os seus pais incentivam você:

Utilize os seguintes Valores

1 = Muito Alto | 2 = Alto | 3 = Médio | 4 = Baixo | 5 = Muito Baixo | 6 = Irrelevante

Por favor, escolha a resposta adequada para cada item:

A terminar o curso e tentar o

$1=$ Muito Alto $\quad 2=$ Alto

$3=$ Médio

$4=$ Baixo

$5=$ Muito Baixo

$6=$ Irrelevante

vestibular para os cursos

superiores

A terminar o curso e ir para o

mercado de trabalho da área

técnica

Eles deixam que você escolha.

[]Em relação ao fato de você ter que estudar na parte da manhã e na parte da tarde no IF durante praticamente toda a semana. O seu rendimento nos estudos:

$*$

Favor escolher apenas uma das opções a seguir

Seu rendimento caiu

Seu rendimento manteve-se o mesmo

Seu Rendimento aumentou

[]Se o curso Integrado do IFNMG - Januária tivesse duração de 4 ANOS ou 3 ANOS e MEIO, com AULAS SOMENTE EM UM ÚNICO TURNO, ou seja, aulas SOMENTE PELA MANHÃ ou AULAS SOMENTE A TARDE. Você: *

Favor escolher apenas uma das opções a seguir:

Ainda assim faria o Curso Integrado no IFNMG de 4 anos ou 3 anos e meio.

Não faria o Curso Integrado no IFNMG, preferiria fazer apenas o Ensino médio de 3 anos em outra instituição.

\section{AVALIAÇÃO DA INSTITUIÇÃO/CURSO (percepções)}

[] 0 seu desejo de trabalhar na área técnica quando você ingressou no curso integrado foi: *

Favor escolher apenas uma das opções a seguir:

$1=$ Muito Alto

2 = Alto

3 = Médio

4 = Baixo

5 = Muito Baixo

$6=$ Imelevante 
[] seu desejo de trabalhar na área técnica HOJE é: *

Favor escolher apenas uma das opções a seguir:

Q 1 = Muito Alto

2 = Alto

3 = Médio

( 4 = Baixo

5 = Muito Baixo

$6=$ Irrelevante

[] Utilizando os índices abaixo, indique o valor (número) para cada ítem:

1 = Muito Alto | 2 = Alto | 3 = Médio | 4 = Baixo | 5 = Muito baixo | 6 = Irrelevante

Por favor, escolha a resposta adequada para cada item:

\begin{tabular}{|c|c|c|c|c|c|c|}
\hline & $1=$ Muito Alto & $2=$ Alto & $3=$ Médio & $4=$ Baixo & $5=$ Muito baixo & $6=$ Irrelevante \\
\hline $\begin{array}{l}\text { Quanto a instituição te prepara } \\
\text { para o vestibular. }\end{array}$ & 0 & 0 & 0 & 0 & 0 & 0 \\
\hline $\begin{array}{l}\text { Quanto a instituição te prepara } \\
\text { para o mercado de trabalho. }\end{array}$ & 0 & 0 & 0 & 0 & 0 & 0 \\
\hline $\begin{array}{l}\text { Quanto você quer se preparar para } \\
\text { o vestibular. }\end{array}$ & 0 & 0 & 0 & 0 & 0 & 0 \\
\hline $\begin{array}{l}\text { Quanto você quer trabalhar como } \\
\text { técnico de sua área de formação. }\end{array}$ & 0 & 0 & 0 & 0 & 0 & 0 \\
\hline
\end{tabular}

[]Qual é o grau de exigência da Instituição quanto às disciplinas do ensino médio? * Favor escolher apenas uma das opções a seguir:

$1=$ Muito Alto

2 = Alto

( 3 = Médio

( 4 = Baixo

5 = Muito Baixo

[]Qual é grau de exigência da Instituição quanto às disciplinas do ensino técnico? * Favor escolher apenas uma das opções a seguir:

$1=$ Muito Alto

2 = Alto

3 = Médio

4 = Baixo

5 = Muito Baixo

[] quanto você acredita estar preparado para o vestibular? *

Favor escolher apenas uma das opções a seguir:

1 = Muito Bem Preparado

O 2 = Bem Preparado

O = Regularmente Preparado

○ 4 = Pouco Preparado

5 = Muito Pouco Preparado 
[]o quanto você acredita estar preparado para o mercado de trabalho de técnico? *

Favor escolher apenas uma das opções a seguir:

1 = Muito Bem Preparado

2 = Bem Preparado

3 = Regularmente Preparado

4 = Pouco Preparado

5 = Muito Pouco Preparado

[]Na sua opinião a Instituição Ihe forma melhor para:

*

Favor escolher apenas uma das opções a seguir:

Prosseguir nos estudos de Nível Superior.

Ir para o mercado de trabalho da área técnica.

Na mesma Medida para Prosseguir nos estudos de Nível Superior e Ir para o Mercado de Trabalho.

[]Em relação à avaliação que você faz da instituição e curso, mensure o seu grau de satisfação: *

Por favor, escolha a resposta adequada para cada item:

A instituição de modo geral.

A infra-estrutura da instituição.

A parte profissionalizante que

você está cursando.

A parte de Ensino Médio que

você está cursando.

Seus professores das

disciplinas da parte

Profissionalizante.

Seus professores das

disciplinas do Ensino Médio.

\section{1 = Ótimo}

0

0

0

0

0
$2=$ Bom(boa)

0

0

0

0

0

0
3 = Regular

0

0

0

0

0
4 = Ruim

0

0

0

0

0
$5=$ Péssimo

[] Quando você iniciou o curso você encontrou o que imaginava?As suas expectativas anteriores à sua entrada foram

atendidas? *Favor escolher apenas uma das opçōes a seguir:

As minhas expectativas foram atendidas de forma positiva. As

minhas expectativas não foram atendidas.

As minhas expectativas foram superadas.

[] Você esta fazendo a parte técnica do seu curso por que: *

Favor escolher apenas uma das opções a seguir:

Porque no Integrado ela é obrigatória.

Porque também quero a formação técnica/profissionalizante.

[]Diante de seu rendimento/desempenho no curso até hoje, a sua expectativa de término do curso se dará: *

Favor escolher apenas uma das opções a seguir:

No tempo regular do curso, ou seja, em 3 Anos.

Fora do tempo regular do curso, ou seja, Maior que 3 Anos.

\section{Expectativa ao Concluir o Curso}

[]Você deseja trabalhar como Técnico em Agropecuária? *

Favor escolher apenas uma das opções a seguir:

$\mathrm{O} \operatorname{sim}$

Não

Estou Indeciso 
[ ] Você deseja fazer um Curso Superior (faculdade) na área do curso técnico em Agropecuária? * Favor escolher apenas uma das opções a seguir
$\mathrm{Sim}$
Não
Estou Indeciso

[]Qual o seu maior objetivo a ser alcançado após a conclusão do curso? *

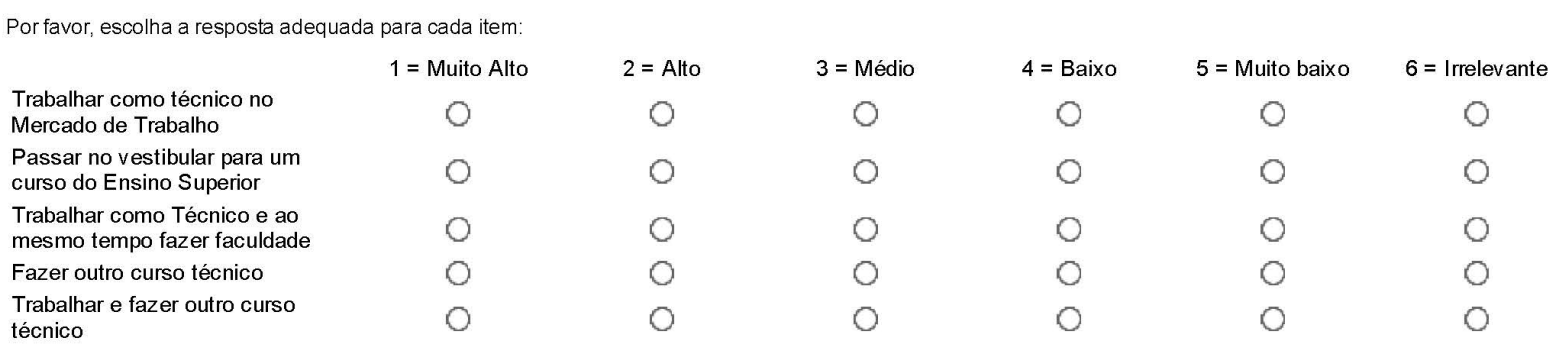

\section{Estágio Supervisionado}

\section{[]Você sabe o que é estágio supervisionado? *}

Favor escolher apenas uma das opções a seguir:

O Sim

Não

[]Você vai fazer (ou está fazendo) Estágio Supervisionado: *

Só responder essa pergunta sob as seguintes condiçöes:

A resposta foi 'Sim' na questão '31 [G4EstagioSup01]' (Você sabe o que é estágio supervisionado?)

Favor escolher apenas uma das opções a seguir:

Porque ele é obrigatório no seu curso

Porque quer se preparar melhor para atuar como técnico em Agropecuária.

[]Você já terminou o estágio supervisionado? *

Só responder essa pergunta sob as seguintes condiçōes:

A resposta foi 'Sim' na questão '31 [G4EstagioSup01]' (Você sabe o que é estágio supervisionado?)

Favor escolher apenas uma das opções a seguir:

O $\operatorname{sim}$

Não

[]A quanto tempo você esta fazendo o estágio supervisionado? *

Só responder essa pergunta sob as seguintes condiçöes:

A resposta foi 'Sim' na questão '31 [G4EstagioSup01]' (Você sabe o que é estágio supervisionado?)

Favor escolher apenas uma das opçōes a seguir:

Ainda não comecei a fazer o estágio supervisionado.

De 08 a 49 Horas

De 50 a 99 Horas

De 100 a 160 Horas

[]O IFNMG lhe informou ou lhe deu acesso a algum documento explicando o que é o Estágio Supervisionado e como funciona? *

Favor escolher apenas uma das opções a seguir:

O Sim

Não 
[]A Instituição auxilia no encaminhamento aos estágios e outras atividades similares fora dela? *

Só responder essa pergunta sob as seguintes condições:

A resposta foi 'Sim' na questäo '31 [G4EstagioSup01]' (Você sabe o que é estágio supervisionado?)

Favor escolher apenas uma das opções a seguir:
$1=$ Muito
2 = Pouco
$3=$ Muito Pouco
4 = Não auxilia

\section{[]Durante o seu estágio supervisionado o professor da área: *}

Só responder essa pergunta sob as seguintes condições:

A resposta foi 'Sim' na questão '31 [G4EstagioSup01]' (Você sabe o que é estágio supervisionado?) e A resposta foi NÃO 'Ainda não comecei a fazer o estágio supervisionado. ' na questão '34 [G4EstagioSup03]' (A quanto tempo vocé esta fazendo o estágio supervisionado?)

Favor escolher apenas uma das opções a seguir:

Acompanha muito desenvolvimento

Acompanha pouco desenvolvimento

Acompanha muito pouco desenvolvimento

Não acompanha o desenvolvimento, apenas assina o termo de compromisso/relatório.

\section{[]Qual a relação das disciplinas com o estágio supervisionado? *}

Só responder essa pergunta sob as seguintes condições:

A resposta foi 'Sim' na questão '31 [G4EstagioSup01]' (Você sabe o que é estágio supervisionado?) e A resposta foi NÃO 'Ainda não comecei a fazer o estágio supervisionado. ' na questão '34 [G4EstagioSup03]' (A quanto tempo vocé esta fazendo o estágio supervisionado?)

Favor escolher apenas uma das opções a seguir:

Muito Relacionado

Pouco Relacionado

Muito Pouco Relacionado

Nenhuma Relação com as Disciplinas Cursadas

[] Como você classifica o ambiente disponibilizado pela empresa (fornecedor do estágio) para a execução do seu estágio? *

Só responder essa pergunta sob as seguintes condições:

A resposta foi 'Sim' na questão ' 31 [G4EstagioSup01]' (Vocé sabe o que é estágio supervisionado?) e A resposta foi NÃO 'Ainda não comecei a fazer o estágio supervisionado. ' na questão '34 [G4EstagioSup03]' (A quanto tempo vocé esta fazendo o estágio supervisionado?)

Favor escolher apenas uma das opções a seguir:

O Ótimo

Muito bom

Bom

Regular

Fraco

[]Você acredita que o Estágio Supervisionado na área de sua formação técnica é importante para sua atuação como Profissional? *

Só responder essa pergunta sob as seguintes condiçōes:

A resposta foi 'Sim' na questão '31 [G4EstagioSup01]' (Vocẻ sabe o que é estágio supervisionado?)

Favor escolher apenas uma das opções a seguir:

Sim

Não

Não Sei Opinar

\section{[]A realização do estágio supervisionado para você: *}

Só responder essa pergunta sob as seguintes condições:

A resposta foi 'Sim' na questão '31 [G4EstagioSup01]' (Você sabe o que é estágio supervisionado?)

Favor escolher apenas uma das opções a seguir:

Pode representar uma oportunidade de emprego no próprio local de trabalho após a conclusão do curso

É importante para saber como aplicar a vivência na escola com a vivência no trabalho

Não é muito importante, pois não pretendo trabalhar como técnico em agropecuária. 
[]Você acredita que o estágio ajuda você a formar para o trabalho? *

Só responder essa pergunta sob as seguintes condiçōes:

A resposta foi 'Sim' na questão '31 [G4EstagioSup01]' (Você sabe o que é estágio supervisionado?)

Favor escolher apenas uma das opçōes a seguir:

$\bigcirc \operatorname{sim}$

$\bigcirc$ Não

Muito pouco

Não sei Opinar. Estou fazendo ou vou fazer porque é obrigatório.

[]Você acredita que a carga horaria de 150 ou 160 horas do estágio supervisionado é suficiente para Ihe preparar para o Mercado de Trabalho como técnico em Agropecuária? *

Só responder essa pergunta sob as seguintes condições:

A resposta foi 'Sim' na questão '31 [G4EstagioSup01]' (Você sabe o que é estágio supervisionado?)

Favor escolher apenas uma das opções a seguir:

O Sim

Não

Não Sei Opinar

[] acompanhamento e a supervisão realizados pela empresa (a fornecedora de estágio) durante o estágio estão sendo: *

Só responder essa pergunta sob as seguintes condiç/öes:

A resposta foi 'Sim' na questão '31 [G4EstagioSup01]' (Vocẻ sabe o que é estágio supervisionado?) e A resposta foi NÃO 'Ainda não comecei a fazer o estágio supervisionado. ' na questão '34 [G4EstagioSup03]' (A quanto tempo você esta fazendo o estágio supervisionado?)

Favor escolher apenas uma das opções a seguir:

Ótimos

Muito bons

Bons

Regulares

Fraco

[]O acompanhamento e a supervisão realizados pelo IFNMG-Januária durante o estágio foram/estão sendo:

Só responder essa pergunta sob as seguintes condições:

A resposta foi 'Sim' na questão '31 [G4EstagioSup01]' (Você sabe o que é estágio supervisionado?) e A resposta foi NÃO 'Ainda não comecei a fazer o estágio supervisionado. ' na questäo '34 [G4Estagio Sup03]' (A quanto tempo vocé esta fazendo o estágio supervisionado?)

Favor escolher apenas uma das opções a seguir:
Ótimos
Muito Bons
Bons
Regulares
Fraco

[]Dentre as opções abaixo indique o nível como ocorreram/ocorrem durante o estágio: *

Só responder essa pergunta sob as seguintes condiçōes:

A resposta foi 'Sim' na questão '31 [G4EstagioSup01]' (Você sabe o que é estágio supervisionado?) e A resposta foi NÃO 'Ainda não comecei a fazer o estágio supervisionado. ' na questão '34 [G4EstagioSup03]' (A quanto tempo você esta fazendo o estágio supervisionado?)

Por favor, escolha a resposta adequada para cada item:

$\begin{array}{lccccc} & \text { Ótimo } & \text { Bom } & \text { Regular } & \text { Fraco } & 0 \\ \begin{array}{l}\text { Exercício de várias atividades } \\ \text { referentes ao curso. }\end{array} & 0 & 0 & 0 & 0 & 0 \\ \begin{array}{l}\text { Desenvolvimento de novas } \\ \text { metodologias e/ou tecnologias. }\end{array} & 0 & 0 & 0 & 0 \\ \begin{array}{l}\text { Uso de equipamentos } \\ \text { tecnológicos modernos. }\end{array} & 0 & 0 & 0 & 0 & 0 \\ \text { Trabalho em equipe. } & 0 & 0 & 0 & 0\end{array}$


Dentre as opções abaixo, marque aquelas que ocorreram/ocorrem durante o estágio:

Você pode marcar mais de uma opção.

*

Só responder essa pergunta sob as seguintes condições:

A resposta foi 'Sim' na questão '31 [G4EstagioSup01]' (Você sabe o que é estágio supervisionado?) e A resposta foi NÃO 'Ainda não comecei a fazer o estágio supervisionado. ' na questão '34 [G4EstagioSup03] (A quanto tempo você esta fazendo o estágio supervisionado?)

Por favor, escolha as opçőes que se aplicam:

$\square$ Atividades restritas a pequena parte do currículo do curso.

$\square$ Desvio de funções, atividades não relacionadas com o curso.

$\square$ Falta de comprometimento da empresa em orientar o estagiário

$\square$ Baixa ou nenhuma remuneração.

$\square$ Sobrecarga de trabalho.

$\square$ Nenhuma das opções acima.

[]Para a realização das tarefas do estágio, os conhecimentos obtidos nas disciplinas do curso foram/estão sendo: *

Só responder essa pergunta sob as seguintes condições:

A resposta foi 'Sim' na questão '31 [G4EstagioSup01]' (Você sabe o que é estágio supervisionado?) e A resposta foi NÃO 'Ainda não comecei a fazer o estágio supervisionado. ' na questão '34 [G4EstagioSup03] (A quanto tempo você esta fazendo o estágio supervisionado?)

Favor escolher apenas uma das opções a seguir

Muito importantes

Importantes

Razoáveis

Irrelevantes

[] Houve a necessidade de aprendizado de outros conhecimentos teóricos/práticos não abordados no seu curso ? *

Só responder essa pergunta sob as seguintes condiçöes:

A resposta foi 'Sim' na questão '31 [G4EstagioSup01]' (Nocê sabe o que é estágio supervisionado?) e A resposta foi NÃO 'Ainda não comecei a fazer o estágio supervisionado. ' na questăo '34 [G4EstagioSup03]' (A quanto tempo vocé esta fazendo o estágio supervisionado?)

Favor escolher apenas uma das opçס̃es a seguir

Sim, Muito

Sim, Alguns

Sim, Pouco

Não, Nenhum

[]As aulas práticas do curso técnico em relação a realidade prática apresentada pelo estágio foi:

Só responder essa pergunta sob as seguintes condiçöes:

A responder essa pergunta sob as seguintes condiçoes: supervisionado. ' na questăo ' 34 [G4EstagioSup03]' (A quanto tempo vocé esta fazendo o estágio supervisionado?)

Favor escolher apenas uma das opções a seguir:

Bem parecidos

Parecidos

Pouco Parecidos

Nada Parecidos

[]Existe um momento formalizado no IFNMG onde os alunos estagiários compartilham os conhecimentos vivenciados no estágio supervisionado? *

Só responder essa pergunta sob as seguintes condições:

A resposta foi 'Sim' na questăo '31 [G4EstagioSup01]' (Vocế sabe o que é estágio supervisionado?) e A resposta foi NÃO 'Ainda não comecei a fazer o estágio supervisionado. ' na questão '34 [G4EstagioSup03]' (A quanto tempo vocé esta fazendo o estágio supervisionado?)

Favor escolher apenas uma das opções a seguir:

Sim

Não 
[] Você acredita que se você colocasse em prática no ambiente de trabalho, aquilo que você aprende aqui no seu Curso do IFNMG, isto o ajudaria a entender melhor os conteúdos das disciplinas e também a lhe formar melhor para

o mercado de trabalho? *

Só responder essa pergunta sob as seguintes condiçöes:
A resposta foi 'Năo' na questão ' 31 [G4EstagioSupo1]' (Você sabe o que é estágio supervisionado?)

Favor escolher apenas uma das opçōes a seguir:

$\mathrm{Sim}$

Não

Não Sei Opinar

Você concluiu o questionário com Sucesso. Obrigado pela Participaçăo 


\section{Apêndice B: Questionário Pesquisa Quantitativa Discente - Meio Ambiente}

OBSERVAÇÃO: No intuito de não sobrecarregar a seção de apêndices com informações repetidas, colocamos aqui somente a única questão que é diferente, do questionário de agropecuária (Apêndice A) devido ao "80 horas".

O questionário de Meio Ambiente é idêntico ao questionário do curso de Agropecuária, onde estiver escrito agropecuária basta ler Meio Ambiente.

[]Você acredita que a carga horaria de $\mathbf{8 0}$ horas do estágio supervisionado é suficiente para lhe preparar para o Mercado de Trabalho como técnico em Meio Ambiente? *

Só responder essa pergunta sob as seguintes condiçöes:

A resposta foi 'Sim' na questão '31 [G4EstagioSup01]' (Você sabe o que é estágio supervisionado?)

Favor escolher apenas uma das opções a seguir:

O $\operatorname{sim}$

Não

Não Sei Opinar 


\section{Apêndice C: Questionário Pesquisa Quantitativa Discente - Informática}

Observação: No intuito de não sobrecarregar com informações repetidas a seção de apêndices, colocamos aqui apenas as três questões diferentes do questionário de agropecuária (Apêndice $A$ ). Todo restante é idêntico ao curso de Agropecuária. Nas questões do apêndice "A" onde estiver Agropecuária, basta ler Informática.

\section{[]Você pretende fazer Estágio Supervisionado: *}

Só responder essa pergunta sob as seguintes condiçöes:

A resposta foi 'Não' na questão '32 [G4EstagioSup01B]' (Você já está fazendo Estágio Supervisionado?)

Favor escolher apenas uma das opções a seguir:

Sim

Não

\section{[]Porque você não pretende fazer o Estágio Supervisionado? *}

Só responder essa pergunta sob as seguintes condiçöes:

A resposta foi 'Não' na questão '33 [G4EstagioSup11]' (Você pretende fazer Estágio Supervisionado:)

Favor escolher apenas uma das opções a seguir:

Eu NÃO tenho interesse em Trabalhar como Técnico em Informática.

Eu Pretendo Trabalhar como Técnico em Informática mas ficaria mais fácil (menos cansativo) concluir o curso NÃO fazendo o estágio Supervisionado.

Outro

[]Você acredita que a carga horaria de 160 horas do estágio supervisionado é suficiente para lhe preparar para o Mercado de Trabalho como técnico em Informática? *

Só responder essa pergunta sob as seguintes condiçöes:

A resposta foi 'Sim' na questão '33 [G4EstagioSup11]' (Você pretende fazer Estágio Supervisionado:)

Favor escolher apenas uma das opções a seguir:

O Sim

O Não

O Não Sei Opinar 


\section{Apêndice D: Entrevista com os Professores - 01}

Local:IFNMG-Campus Januária

Nome Completo:
Data:

Hora:

Função:

1) O que diferencia os Institutos Federais que ofertam o Ensino Médio Integrado das outras Instituições que ofertam o Ensino Médio Regular?

2) Na sua percepção o que mais atrai os alunos ao IFNMG Januária: a profissionalização ou $\circ$ ensino propedêutico para prosseguimento em estudos de nível superior.

3) Qual a importância do estágio supervisionado nos cursos profissionalizantes do IFNMG-Januária?

4) Qual a razão dos cursos Integrados Agropecuária e Meio Ambiente terem cargas horárias diferentes (150 e 80 respectivamente)?

5) Por que no curso Técnico Meio Ambiente Subsequente a carga horária do estágio é de 160 horas enquanto que no mesmo curso na modalidade integrado é de 80 horas?

6) Por que a carga horária do estágio supervisionado de agropecuária passou de 160 para 150 horas?

7) Por que o curso técnico integrado em informática possui estágio supervisionado opcional?

8) Na sua opinião, qual o impacto na formação do aluno de informática integrado caso ele opte em não fazer o estágio supervisionado?

9) Como e quando são disponibilizadas as informações acerca do estágio supervisionado aos discentes?

10) Você acredita que 80 ou até mesmo 150 horas são suficientes para satisfazer o estágio supervisionado, como Permear disciplinas, socialização, análise crítica... nos cursos integrados que possuem no mínimo 3.300 horas?

11) Sendo que os alunos ficam pela manhã e tarde cursando as disciplinas, quando é que realizam o estágio supervisionado?

12) No período de férias como fica o acompanhamento efetivo do professor uma vez que esses profissionais também estão de férias?

13)Qual a sua opinião sobre a extensão do curso integrado para 3 anos e meio ou 4 anos com aulas num único turno?

14)Antes de encerramos a entrevista você gostaria de fazer algum comentário? 


\section{Apêndice E: Entrevista com os Professores - 02}

Local: IFNMG-Campus Januária

Nome Completo: data:

hora:

Função:

1) O que diferencia os Institutos Federais que ofertam o ensino Médio Integrado das outras Instituiçōes que ofertam o Ensino Médio Regular?

2) $\mathrm{Na}$ sua percepção o que mais atrai os alunos ao curso integrado em informática: a profissionalização ou o ensino propedêutico para prosseguimento em estudos de nível superior.

3) Qual a importância do estágio supervisionado nos cursos de informática integrado e subsequente?

4) Porque no curso subsequente o estágio é obrigatório enquanto que no curso integrado é opcional?

5) Quantos pedidos em média você já recebeu de alunos do integrado que irão estagiar?

6) Como e quando são disponibilizadas as informações acerca do estágio supervisionado aos discentes do integrado informática?

7) Como é feito o acompanhamento do estagiário pelo professor orientador?

8) As 160 horas de estágio supervisionado estão sendo suficientes para permear o desenvolvimento dos diversos componentes curriculares do curso integrado em informática que possui mais de 3.300 horas e também promover o ato educativo como um todo (socialização, visão crítica...)?

9) Qual a sua opinião sobre estender o curso técnico integrado para 3 anos e meio ou 4 com aulas num único turno?

10) Sendo que os alunos ficam pela manha e tarde cursando as disciplinas, quando é que realizam ou realizariam o estagio supervisionado?

a. No período de férias como fica o acompanhamento efetivo do professor conforme uma vez que os professores também estão de férias?

11) Existe um momento formalizado no curso onde os alunos compartilham as experiências vivenciadas no estágio supervisionado?

12) Antes de encerrarmos a entrevista gostaria de fazer algum comentário? 


\section{Apêndice F: Entrevista com os Professores - 03}

Local:IFNMG-Campus Januária Data:

Nome Completo:
Hora:

Função:

1) $O$ que diferencia os Institutos Federais que ofertam o ensino Médio Integrado das outras Instituições que ofertam o Ensino Médio Regular?

2) Na sua percepção o que mais atrai os alunos ao IFNMG Januária: a profissionalização ou o ensino propedêutico para prosseguimento em estudos de nível superior

3) Qual a importância do estágio supervisionado no curso integrado Agropecuária?

4) Porque a carga horária do estágio supervisionado de agropecuária passou de 160 para 150 horas?

5) Como e quando são disponibilizadas as informações acerca do estágio supervisionado aos discentes?

6) Às 150 horas do estágio supervisionado estão sendo suficientes permear o desenvolvimento dos diversos componentes curriculares dos curso que possui 3.750 horas e também promover o ato educativo como um todo (socialização, visão critica...)?

7) Sendo que os alunos ficam pela manha e tarde cursando as disciplinas, quando é que realizam o estagio supervisionado?

a. No período de férias como fica o acompanhamento efetivo do professor uma vez que esses profissionais também estão de férias?

8) Como é feito o acompanhamento do estagiário pelo professor orientador?

9) Existe um momento formalizado no curso onde os alunos compartilham as experiências vivenciadas no estágio supervisionado?

10) Qual a sua opinião sobre a extensão do curso integrado para 3 anos e meio ou 4 anos com aulas num único turno.

11)Antes de encerramos a entrevista gostaria de fazer algum comentário? 


\section{Apêndice G: Entrevista com os Professores - 04}

Local: Data: Hora:

Nome Completo:

Função:

1) $O$ que diferencia os Institutos Federais que ofertam o ensino Médio Integrado das outras Instituições que ofertam o Ensino Médio Regular?

2) Na sua percepção o que mais atrai os alunos ao curso integrado Meio Ambiente: a profissionalização ou 0 ensino propedêutico para prosseguimento em estudos de nível superior?

3) Qual a importância do estágio supervisionado nos cursos Meio Ambiente integrado e subsequente?

4) Porque no curso Técnico Meio Ambiente Subsequente a carga horária do estágio é de 150 horas enquanto que no mesmo curso na modalidade integrado é de 80 horas?

5) Como e quando são disponibilizadas as informações acerca do estágio supervisionado aos discentes?

6) As 80 horas do estágio supervisionado são suficientes para permear o desenvolvimento dos diversos componentes curriculares do curso integrado em meio ambiente que possui 3.300 horas e também promover 0 ato educativo como um todo (socialização, visão crítica...)?

7) Qual a sua opinião sobre estender o curso técnico integrado para 3 anos e meio ou 4 com aulas num único turno?

8) Sendo que os alunos ficam pela manhã e tarde cursando as disciplinas, quando é que realizam/realizariam o estagio supervisionado?

a. No período de férias como fica o acompanhamento efetivo do professor uma vez que esses profissionais também estão de férias?

9) Como é feito o acompanhamento do estagiário pelo professor orientador?

10) Existe um momento formalizado no curso onde os alunos compartilham as experiências vivenciadas no estágio supervisionado?

11) Antes de encerramos a entrevista gostaria de fazer algum comentário? 


\section{Apêndice H: Termo de Responsabilidade Para Acesso ao Banco de Dados de Egressos do IFNMG}

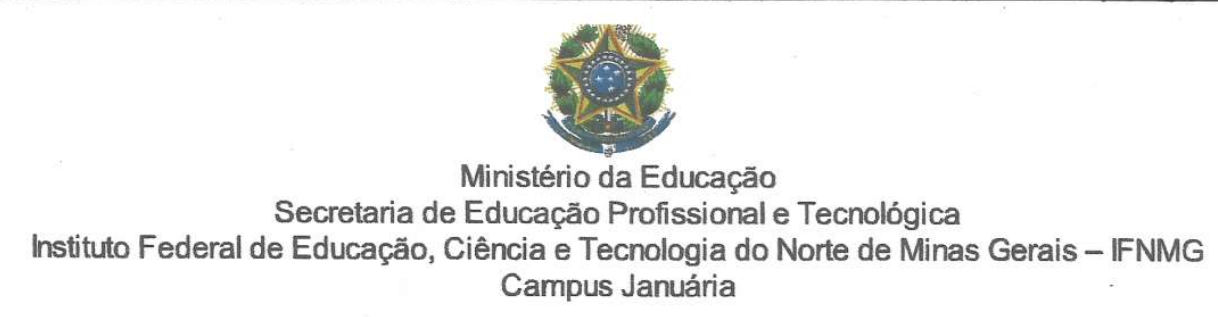

Memorando no. 01/2014

Januária, 29 de Outubro de 2014.

Ao Diretor de Extensăo

Sr. Kleber Carvalho dos Santos

IFNMG - Instituto Federal do Norte de Minas Gerais

ASSUNTO: Autorização para acesso a Banco de Dados

Com meus cordiais cumprimentos,

Senhor Diretor, como aluno do Mestrado Profissional em Educação da Universidade de Brasilia - UNB, preciso realizar uma pesquisa na instituição em que trabalho e produzir uma dissertação referente ao assunto pesquisado.

O assunto que pretendo pesquisar refere-se aos cursos técnicos, especificamente quanto o perfil de nossos alunos, sua trajetória, seus anseios...

Para realização da pesquisa, preciso ter acesso aos dados do questionário de egressos divulgado pela Diretoria de Extensão.

O produto gerado pela pesquisa dependerá da análise dos dados do questionário de egressos em conjunto com a análise do perfil discente, e poderá ser, por exemplo, uma proposta de mudança curricular, uma proposta de um novo curso técnico; entre outras propostas que visem beneficiar o ensino profissionalizante no IFNMG-Januária.

Assim, solicito a autorização de V.S ${ }^{a}$ para que possa ter acesso aos dados dos alunos do questionário de acompanhamento de egressos, comprometendo-me a ter os devidos cuidados éticos, como não divulgar nomes de alunos, não utilizar dados de documentos pessoais, etc.

Ciente de vossa compreensão, desde já agradeço.

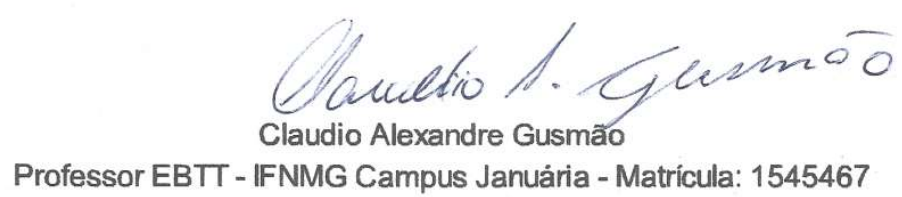

Fazenda São Geraldo S/Nº - Estrada Januária, Km 06 - Bom Jardim, Cx. Postal 97 - CEP 39480000 Telefone: (38) 3629.4600 - E-mail: comunicacao.januaria@ifnmg.edu.br 


\section{Apêndice I: Termo de Consentimento Pesquisa Discente}

\section{TERMO DE CONSENTIMENTO LIVRE E ESCLARECIDO}

Prezado(a) participante:

Sou estudante do curso de Mestrado Profissional em Políticas Públicas e Gestão da Educação Profissional e Tecnológica, da Faculdade de Educação da UnB-Universidade de Brasília.

Estou realizando uma pesquisa sob supervisão da Professora Dra. Olgamir Francisco Carvalho, cujo objetivo é analisar as informações dos alunos dos cursos da modalidade integrado com o intuito de promover melhorias.

Sua participação envolve em responder um questionário eletrônico com perguntas fechadas. È TOTALMENTE ANÔNIMO.

A participação nesse estudo é voluntária e se você decidir não participar ou quiser desistir de continuar em qualquer momento, tem absoluta liberdade de fazê-lo.

Mesmo não tendo benefícios diretos em participar, indiretamente você estará contribuindo para a compreensão do fenômeno estudado, para a produção de conhecimento científico e para a melhoria da política pública.

Quaisquer dúvidas relativas à pesquisa poderão ser esclarecidas pelo pesquisador fone (38) XXXX-XXXX / E-Mail: claudio.gusmao@ifnmg.edu.br.

Atenciosamente,

Prof. Claudio Alexandre Gusmão

IFNMG Campus Januária

Consinto em participar deste estudo e declaro ter recebido uma cópia deste termo de consentimento.

Nome do participante

Data: / /2015 Januária-MG 


\section{Apêndice J: Termo de Consentimento Pesquisa Docente}

Termo de Consentimento para participação em Entrevista

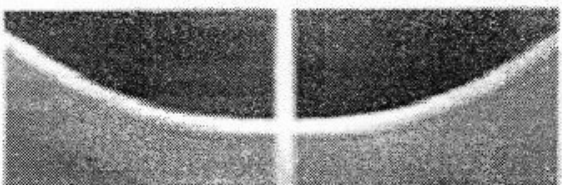

Universidade de Brasilia

FACULDADE DE EDUCACÃO

PROGRAMA DE PÓS-GRADUAÇÃO EM EDUCAÇÃO MESTRADO PROFISSIONAL

\section{Termo de Consentimento parà participação em Entrevista}

Esta pesquisa se propõe a analisar o perfil dos discentes do Ensino Médio Integrado em especial como é operacionalizado o Estágio Supervisionado no Instituto Federal do Norte de Minas Gerais, Campus Januária.

Trata-se de atividade referente ao curso de Mestrado Profissional em Políticas Públicas e Gestão da Educação Profissional e Tecnológica do Programa de Pós-Graduação em Educação da Universidade de Brasília.

Para a realização desta pesquisa, gostaríamos de contar com a sua colaboração, por meio da participação em entrevista.Trata-se de um ato voluntário, no qual você tem total liberdade para expressar o que pensa sobre o tema em debate. Neste sentido, pedimos que sinta-se à vontade para participar da maneira como achar melhor.

Para a presente pesquisa salientamos a garantia do anonimato a todos os participantes. Dessa forma, solicitamos sua autorização para gravação desse momento e para apresentar os resultados no estudo acima referido.

Caso deseje conhecer os resultados desse trabalho, por favor, contatar o responsável abaixo identificado.

Deste já agradecemos sua colaboração.

\section{Claudio Alexandre Gusmão}

Mestrando da Faculdade de Educação - UnB

claudio.gusmao@ifnmg.edu.br / (38)

Certifico haver lido o conteúdo acima descrito e compreender que os dados serão mantidos em sigilo e que estou participando voluntariamente. Pela presente, dou meu consentimento para participar do estudo e para a publicação dos resultados.

$$
\text { Januária- } \mathrm{MG} \text {, }
$$
de de 2015.

Assinatura do participante 